\title{
OVERLEVERINGEN EN ZANGEN DER ZUID-TORADJA'S
}


I.S.B.N. 90.247 .2196 .2

$H$, van der Veen - 978-90-04-28716-7 Downloaded from Brill.com@4/26/2023 02:54:12PM via free access 


\section{E R H A N D E L I N G E N}

VAN HET KONINKLIJK INSTITUUT VOOR TAAL-, LAND- EN VOLKENKUNDE

\section{5}

H. VAN DER VEEN

\section{OVERLEVERINGEN EN ZANGEN DER ZUID-TORADJA'S}


H. van der Veen - 978-90-04-28716-7 Downloaded from Brill.come4/26/2023 02:54:12PM via free access 


\section{VOORWOORD}

Nadat Dr. H. van der Veen in 1965 en '66 twee bundels Zuid-Toradjase teksten had laten verschijnen (in VKI, 45 en 49), zette hij zich tot de bewerking van een derde bundel, die wederom een aantal teksten met vertaling en aantekeningen zou bevatten. Omstreeks 1975 was dit werk klaar en diende hij het ter publicatie in bij het Koninklijk Instituut voor Taal-, Land- en Volkenkunde. Omdat de stukken in handschrift waren en ook op andere punten nog niet geheel voldeden aan de eisen die aan een persklaar stuk moeten worden gesteld, nam $i k$, op verzoek van de redactiecommissie van het KITLV en in overleg met Van der Veen, de taak op mij om de laatste hand aan het persklaarmaken te leggen. Gedurende ongeveer anderhalf jaar kon ik vragen die bij mij rezen met de auteur bespreken, alsook de kleine wijzigingen (meestal inconsequenties en onduidelijkheden betreffende) die ik nodig oordeelde. Bij Van der Veens dood, in oktober 1977, was dit werk gevorderd tot en met de tekst $\mathrm{F}$. Bij de teksten $\mathrm{G}$ en $\mathrm{H}$ heb ik die ruggespraak node gemist.

Omdat het ernaar uitzag dat met de uiteindelijke publicatie van de bundel nogal wat tijd gemoeid zou zijn, werd in 1976 besloten de eerste tekst (A) van de bundel, getiteld "Ossoran tempon daomai langi"" (Overleveringen van den beginne vanuit de hemel in geregelde volgorde meegedeeld), bij wijze van voorproefje te publiceren in de Bijdragen tot de Taal-, Land-en Volkenkunde, en wel in deel 132 (1976), p. 418-438.

Deze publicatie verschilt op twee punten van zijn voorgangers. Ten eerste moest, o.a. om het verschijnen niet nog langer te vertragen, ervan worden afgezien Van der Veens Nederlandse vertaling en aantekeningen in het Engels te laten vertalen. En ten tweede werd, omdat bij traditionele wijze van zetten en drukken het boek (wegens de uiteraard kleine oplage) exorbitant duur zou worden, besloten tot een fotomechanische offset-uitgave van het persklare, getypte manuscript. Afgezien van deze uiterlijke verschillen is de bewerking van deze derde bundel zoveel mogelijk gelijk aan die van de eerste twee.

Indien Van der Veen dit voorwoord zelf zou hebben geschreven, had hij ongetwijfeld uitgesproken hoeveel hij verschuldigd was aan zijn ZuidToradjase medewerkers J. Tammu en L. Pakan. Aan hen dankt de uitgave 
inderdaad veel, o.a. omdat $z i j$ in een uitvoerige correspondentie over allerlei duistere plaatsen meedachten en meestal een goede oplossing ervoor wisten te vinden. Zo is deze bundel het sluitstuk van een in het geval van Tammu vijftigjarige, in dat van Pakan ruim veertigjarige samenwerking met Van der Veen.

Mede namens de redactiecommissie van het KITLV spreek ik ook mijn dank uit aan de heer E. Smits, die met grote accuratesse de gehele tekst uittypte, en aan zijn werkgever, het Nederlands Bijbelgenootschap, die hem gedurende ruim een jaar voor ongeveer een tiende van zijn tijd afstond voor dit werk.

De hier gevolgde spelling van het Zuid-Toradjaas sluit zo nauw mogelijk aan bij die van het Indonesisch welke gold tot augustus 1972, met één uitzondering: de z.g. glottisslag aan het eind van een lettergreep of een woord wordt niet door een $k$ aangeduid, maar door een apostrof (').

De pepet komt in het Zuid-Toradjaas niet voor; $e$ staat dus alleen voor de é-klank.

Het in de twee vorige bundels gebruikte teken $\eta_{3}$ leverde moeilijkheden op bij de gekozen productiewijze; daarom wordt de velare nasaal gewoon door $n g$ weergegeven.

De tekst die nu met $\mathrm{E}$ Ib is aangeduid, was oorspronkelijk gemerkt met de letter D. Dat is de reden waarom in de inhoudsopgave thans een tekst met die letter ontbreekt.

J.L. Swellengrebel

Leiden, 8 december 1978 
OVERLEVERINGEN EN ZANGEN

B. Landomindun na Mendurana, Landorundun en Mendurana Redactionele noot . • . . . . . . . . 1

Tekst met vertaling en aantekeningen . . . 2

C. Tangdona sulle gajangna Bullu Matua, De eedzwering van de majestueuze opvolger van Bullu Matua Inleiding • • • • • • • • • • • • 17

Tekst met vertaling en aantekeningen . . . 18

E. Over de twee redacties van E I . . . . . . 38

- Ia. GeZong Maro Ne' Nora', De Maro-zang van Ne' Nora'

Inleiding • • • • • • • • • • • • 38

Tekst met vertaling en aantekeningen . . . 42

- Ib. Gelong Maro Sangaju', De Maro-zang van Sangaju'

Inleiding • • • • • • • • • • • • 109

Tekst met vertaling en aantekeningen . . . 110

- II. GeZong Massinggi', Lofzang

Inleiding . • • • • • • • • • • • 129

Tekst met vertaling en aantekeningen . . . 130

- III. Singgi' GeZong Talzang, De lofprijzing de bamboe

bezingende

Inleiding • • • • • • • • • . • . 135

Tekst met vertaling en aantekeningen . . . 136

- IV. Gelong bate, De bate-zang

Inleiding . • • • • • • • • • • • 155

Tekst met vertaling en aantekeningen . . . 156

F. Ossoran bugi', Overlevering van de zang ter gele-

genheid van het bugi'-feest

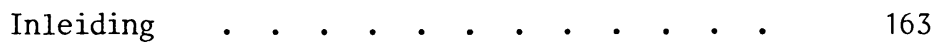

Tekst met vertaling en aantekeningen • • • 166

G. Singgi'Bua' Padang, Lofprijzing ter gelegenheid

van het Bua' Padang-feest

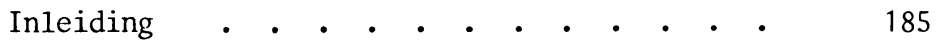

Tekst met vertaling en aantekeningen . • . 186 
H. Algemene inleiding. Het bua' kasalle'-feest . .

I. Singgi' tondok, Lofzang op de gemeenschap der

dorpen

Inleiding

Tekst met vertaling en aantekeningen . .

- II. Urrodo bangkula' to, kakua, Men schudt de bel en

zegt

Inleiding $\quad \cdot \quad \cdot \quad \cdot \quad \cdot \quad \cdot \quad \cdot \quad \cdot$.

Tekst met vertaling en aantekeningen . • .

- III. Singgi' to barani, Lofprijzing op de held

Inleiding . . . . . . . . . . .

Tekst met vertaling en aantekeningen . . .

- IV. Singgi' kaunan sola pia, Lofprijzing op de slaven

en de kinderen

Inleiding . . . . . . • . . . . . 276

Tekst met vertaling en aantekeningen . • . 278

LIJST VAN ZUID-TORADJASE NAMEN, INOORDEN EN UITURUKKINGEN DIE MEER DAN EENMAAL IN DE TEKSTEN VOORKOMEN

AFKORTINGEN EN AANGEHAALDE GESCHRIFTEN . $\cdot$. 


\section{TEKST B}

Redactionele noot

Evenals de in het voorwoord genoemde tekst A, getiteld Ossoran tempon daomai Zangi' (Overlevering van den beginne vanuit de hemel, in geregelde volgorde medegedeeld), werd tekst B gereciteerd door $\mathrm{Ne}^{\prime} \mathrm{Mani}$ ', een priester afkomstig uit Bori' in Sereale. De inhoud bestaat uit overleveringen die grotendeels ook voorkomen in of parallel lopen met wat de eerstgenoemde tekst vertelt. Alleen het laatste stuk, ongeveer een derde deel van het geheel, vertelt iets dat in tekst A in het geheel niet voorkomt. Daarom werd, nog in overleg met Dr. van der Veen, besloten om alleen dit gedeelte van tekst B op te nemen in deze bundel. Het handelt over de afstamming van de Toradjase goddelijke prinses Landorundun en vertelt hoe de Bonese prins Mendurana haar tot vrouw verwierf.

De titel van tekst B luidt: Ossoran nene' Zan Zino (Overlevering omtrent de voorouders op aarde). Aan het hier gepubliceerde gedeelte gaf de redactie een aparte titel: Landorundun en Mendurana.

De voetnoten bevatten aantekeningen van Dr. van der Veen, waarin volkenkundige en geografische bijzonderheden worden besproken en opheldering wordt gegeven over onduidelijke woorden en uitdrukkingen in de tekst. 


\section{LANDORUNDUN NA MENDURANA}

Denmi tau tamanang, nasassangmi ra'pean piong sola manuk mabusa baba'na, nasule makianakan.

Malemi unnola Sarong Lambe'susu, ullamban pangkalo' puang, unteka' Limbongana11o; mangunu'mi sumpu dilangi'; ma'tingke' tu'tun dibatara.

Narangimi Salokang langngan Seko. Randukmi tumangke suru' Salokang

- suru'na asu ranganan -; tamami pangala' tamman, unnola to' TedongTedong, rampomi daa Batu; buda pa'mali-mali, buda nabukai ulang, dikki' simbuni-buni, dikki' nako'ka' peampunna.

Landa'mi tama rampanan kapa', sirampanan kapa' Lambe'susu.

Ditambukmi Landorundun sangtaun pare, kamma la sangpealloan. Dialliammi balo'na "Sangtolinoan" lian Ponglu' (Pangala'), naruku'mi kakianakan.

Nakuami: "Alangki' kandian tedong, tamesuso lolanan, tabaai, takandian, la laoki' sau' Pangden."

Didadiammi Landorundun, nakabu' bangpa rundunna.

Nakuami Salokang: 'Kukua rara' kukombong, bulaan kukianakan, nasusi oto' pune. Benmo' uase to pande, kulallai botto ulunna, nasombo kale datunna."

Nakuami Lambe'susu: 'Da mutoeanni massangpali' rengnge'. Sussunni ria tu aluk mangria dua rokko Lemo."

1) nasassang: zij liep overal doorheen, bv. door struikgewas.

2) ra'pean piong, 1tl. het aftrekken van de buitenlaag van de bamboe, in welke kleefrijst gekookt wordt; deze uitdrukking geeft te kennen het verrichten van gebeden gepaard gaande met offers van in bamboekokers gekookte rijst.

3) Sarong is een kampong in het landschap Pangala'.

4) Limbonganallo is een plaats in het complex Baruppu'.

5) To' Tedong-Tedong: plaats tussen Baruppu' en het gebied Makki' in het beneden stroomgebied van de Karama-rivier gelegen.

6) Batu is de naam van een rotsvesting, waar Pong Tiku zich verschanst heeft in zijn strijd tegen het Ned.-Ind. leger.

7) pa'mali-mali = pa'maling-maling: daden, die de mensen versteld doen staan.

8) pecmpu: bezitter van iets, hier van een geheime wetenschap.

9) Een rijstjaar is de tijd van zeven maanden, gerekend van af dat de rijst gezaaid wordt tot en met de periode van het oogsten. 


\section{LANDORUNDUN EN MENDURANA}

Er was een kinderloze vrouw, zij bracht overal doorheen lopend 1) offers van in bamboegeledingen gekookte rijst 2) en een hoen met een witte oorlel; toen zij terugkwam baarde zij een kind.

Lambe'susu ging langs Sarong 3), zij stak de rivier over en steeg op naar Limbonganallo 4); zij spon één draad; die reikte tot het uitspansel; zij vormde spinsel tot aan de hemel.

Dat vernam Salokang in Seko in de hoogte. Hij ving aan een offer te brengen op een offerstelletje - zijn offer was een jachthond -; hij ging het dichte woud in, ging langs To' Tedong-Tedong 5) en kwam in Batu 6) aan; vele waren zijn wonderkunsten 7), veel wist hij te ontknopen, vaak wist hij zich zelf of iets onzichtbaar te maken voor de mensen, het geheim van vele kunsten, dat slechts de bezitters daarvan bekend was 8), wist hij te raden.

Terstond trad hij in het huwelijk, hij huwde met Lambe'susu.

Landorundun was in de moederschoot gedurende een vol rijstjaar 9), bijna sinds een volle droge tijd. Men had voor haar de amulet "de mensheid" gekocht aan de overzijde in Ponglu' (in Pangala'); de tijd van het baren naderde.

Hij zeide: 'Haal ons de etensbak der buffels, dat wij schelpdiertjes zoeken onderweg, die brengen en ze eten bij de rijst; wij willen Zuidwaarts naar Pangden gaan".

Toen werd Landorundun ter wereld gebracht, zij was met haar bedekt.

Salokang zeide: "Ik zeide: ik verwek een meisje, ik doe een jongen ter wereld komen en het is als de tronk van een boomvaren. Geef mij de bijl van een timmerman, dat ik de kruin van haar hoofd splijte, oprat haar edel lichaam verschijne".

Lambe'susu zeide: "Denk goed door. Leg de verantwoording op het hebben van een tweede vrouw, van welke de ene in Lemo is" 10).

10) De zin van deze woorden is: de geboorte van dit abnormale meisje is te wijten aan het feit, dat je twee vrouwen hebt, omdat je niet gescheiden was van je vrouw in Lemo. Lemo is een complex gelegen in het gebied van Seko, dat door To Rongkong bewoond wordt. 
Nakua: "Iko ria Lambe'susu, umbai denpa aluk mukamalingi?" Mebalimi Lambe'susu, nakua: 'Mangkamo kibukai ulang tu sikande ula', tu pakelokelo, tu lambakkalo' do Napo. Iko ria Salokang, ba'tu tang denpa aluk mukamalingi?"

Nakuamo Salokang: 'Umbai iamo tu Tumba' Peanean, kutampe bangpa dao mai Seko, tae'pa kupakkanni rampanan kapa'. Apa tambaimi to minaa, napa'peissananni lako to umpondok rampanan kapa'; dao sia lu tu bassi sangbintan, dao sia lu tu rendenan tedong, dao sia lu tu uma, iamo napokapa' to!"

Dipa'peissananni lako to umpondok rampanan kapa': Manurundilangi' sola Marrindiliku.

Tibukami dua rundun, tiko'ka'mi tallu beluak.

Tallu ratu' dangkananna, sangpulo pitu da'pana.

Kasalle dadinna Landorundun, lobo' garaganna. Malemi rokko Sikuku' ma'luang lemo (napatama lemo tu beluakna).

Naparundu' salu sau',

napopentete randanan,

rampori tangngana tasik.

Natiromi Mendurana,

unnorong tangngana tasik.

Disua tau unnorongi, tama tasik, sule tu tau sekko', sule buta.

Nabatangimi Mendurana tama unnorongi, naalai. Nabungka'mi Mendurana, naalami tu beluak, nada'pai: tallu ratu' dangkananna, sangpulo pitu da'pana.

Ma'kadami Mendurana, nakua: "Ianna baine umpobeluakki te, la kupobaine. Ianna muane, la ma'polo lolona."

Umpasassangmi mundan to' bura-bura, tui-tui tasik sola kalumpini' rante, lao undaka' tinde to ma'beluak. Sule tui-tui tasik, tae' natiroi tu rundun. Sule mundan to' bura-bura, tae' natiroi tu rundun.

11) rendenan tedong, 1tl. het achter zich aantrekken van buffels.

12) kapa' is de boete, te betalen door degene der echtgenoten, die de regels van de echtverbintenis overtreedt.

13) Sikuku' is de plaats in het conplex Baruppu' tussen twee uitstekende punten van het gebergte in, zodat er een nauwe pas is ontstaan, die naar de rotsvesting Batu voert, zie noot 6 .

14) Mendurana, vgl. het Oudboeginese (Arung) Worowane, volgens Matthes, Boeg. Wrdb.

15) ma'polo Zolo, 1t1. de navelstreng delen met.

16) tui-tui tasik, elders: tii-tii tasik, 1tl. "wilde eend van de zee", een kleine soort van wilde eenden. 
Hij zeide: "Jij toch, Lambe'susu, misschien is er nog een adatregeling, waarover je verbijsterd bent?" Lambe'susu antwoordde en zeide: 'Wij ontsluieren de ontucht van naverwanten, het onverhoeds overvallen, het in overtreding zijn boven in Napo. En jij dan toch, Salokang, of er dan geen adatregeling is waarover $j i j$ verbijsterd bent?"

Salokang zeide: 'Misschien die Tumba' Peanean, die ik maar heb achtergelaten daar boven in Seko hierheen komende, voor wier huwelijk ik nog niet de verantwoording heb gedragen. Maar roep de to minaa, dat hij het late weten aan degene, die het huwelijk heeft ingezet; daar ginds boven is een bundel ijzer, daar ginds boven zijn er buffels 11), daar ginds boven zijn sawahs, die men kan aanwenden voor de boete". 12)

Het werd ter kennis gebracht van hen, die het huwelijk hadden ingezet: Manurundilangi' en Marrindiliku.

Twee lange haren gingen los,

drie haren raakten uit de knoop;

Driehonderd span

zeventien waren de vademen er van.

Bij het opwassen ontwikkelde de gestalte van Landorundun zich flink. Toen ging zij benedenwaarts naar Sikuku' 13) en omhulde zich met een citroen (zij deed een van haar haren in een citroen).

Die volgde de rivier Zuidwaarts,

ze ging steeds langs de oever,

ze bereikte het midden van de zee.

Toen zag Mendurana ze,

hij zwom naar het midden van de zee.

Er werd iemand gezonden om naar het midden van de zee te zwemmen, die man keerde krom vergroeid terug, hij keerde blind terug.

Mendurana 14) ging in eigen persoon er in, zwom er heen en haalde ze. Mendurana opende ze, hij nam het haar en mat het bij vademen: driehonderd span, zeventien vademen.

Mendurana sprak: "Indien een vrouw dit als haar heeft, dan wil ik haar huwen, indien het een man is wil ik een broeder van hem zijn". 15)

Hij liet wilde eenden, die zich in het schuim ophouden hier en daar heen lopen en kleine wilde eenden 16) en zwaluwen van het veld om degene, die dat haar had te gaan zoeken. De kleine wilde eenden keerden terug, zij hadden het haar niet gezien, de wilde eenden, die zich in het schuim ophouden keerden terug, ze hadden het haar niet gezien. 
Sule kalumpini' rante, nakua:

"Pong Tau, Pong Tau Allo,

Pong Tiboong ri bisara,

Pong Tau la kegagaran.

Kukita-kitamo rundun,

daari ulunna salu,

tiparitikna uai,

tiguririkna kambuno."

Mambala lembangmi Mendurana, untongkonnimi laa'na lembang, umpasampangmi sakke a'sin. La lu rekkemi Sa'dan tu lembangna, nakuami kaluppini':

"Pusamo, pusamo lembang, sala' lalanmo orongan, tang tibatakmo lambanan."

Lu rekkemi Tikala tu lembangna, saemi rekke Tangkin, ussangkinmi lembangna. Makaro tanami rekke tu Mendurana. Saemi rekke Likulambe'. Umbitting-bittingmi rundun, ungkadaemi beluak.

Nakuami Landorundun:

'Mindako nabongka asu, naburoro loto'-loto', naliling asu rangnganan?

Mato mambela tondokna, melaliuk tambulinna, melatik mata dokena. Baolummuraka ronno', buamuraka merena'? Dendaka pa'peindanmu, pa'peutang masaimmu? Ia mutungka mutuntun, mupa'ulu karoenni?"

Nakuami Mendurana:

'Tang baolungkura ronno', tang buakura merena'.

17) kambuno: waaierpalm, Livistona rotundifolia.

18) $\mathrm{Za}^{\prime}$, 1t1. hetgeen aan de nek van een dier is, inzonderheid dicht bij de bult op de rug.

19) Zambanan, 1tl. het vaartuig, waarmee men oversteekt.

20) Tangkin: plaats in het landschap Tikala. 
De zwaluwen van het veld keerden terug en zeiden:

"Edele Heer, Heer Zonnemens, Heer, de Geweldige in uw gedragingen,

Edele Heer, die een krachtig doorzettingsvermogen zal hebben. Ik zag steeds het haar, in het Noorden aan de bovenloop van de rivier, waar het water druppelsgewijs vloeit, waar de waaierpalmen omheen staan". 17)

Mendurana maakte een prauw met de dissel, en zette zich aan de voorsteven 18) en deed het zoute water als vloed opkomen. Toen zijn prauw stroomopwaarts de Sa'dan zou opgaan, zeiden de zwaluwen:

"Verkeerd gegaan, verkeerd gegaan is de prauw,

de koers van het vaartuig is mis,

de boot 19) kan niet meer verder gaan".

Zijn prauw ging Noordwaarts naar Tikala, toen kwam hij Noordwaarts bij Tangkin 20) en bond zijn prauw aan een boom vast. Mendurana ging nu over land Noordwaarts. Hij kwam Noordwaarts bij Likulambe'.

Hij trachtte het haar naar zich toe te trekken, hij strekte zijn hand uit naar het haar.

Toen zeide Landorundun:

'Wie is het tegen wie de hond blaft, tegen wie het zwartje 21) bast, om wie de jachthonden heenlopen?

Blijkbaar iemand uit een verre streek, wiens graafstok de adem uitzet om te fluiten, wiens lanspunt glimlacht. Is uw betel neergevallen, is uw arecanoot neergestort als een korrel uit de aar? Hebt gij een schuldvordering, een debeteis van lang her, is het die, die gij als eis komt vorderen, waarvoor gij met onbedekt hoofd komt, zoals iemand, die in de vooravond op weg is?"

Toen zeide Mendurana:

"Niet mijn betel is neergevallen, niet mijn arecanoot is neergestort.

21) Zoto'-Zoto' is een verkleinwoord van Zotong: zwart, gebezigd van honden en hoenders. 
Tae'ra pa'peindangku, pa'peutang masaingku.

Beluak aku kutiro, rundun aku kupenunu, unnarrang tangngana tasik, ussuloi bura-bura.

Ia kulando lalanni, ia kutungka mambela."

Nakuami Landorundun, kadanna Landobeluak:

"Kabuto-buto te Londong, umpokada pokon, tae', ussa'bu' kapipe, 10'bang. La muapari mulambi', mudete mukilalai, daari ulunna langi', ma' rangkapanna deata?"

Nakuami Mendurana:

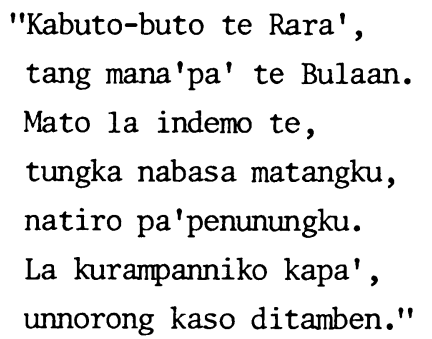

Unnilingmi Landorundun, nokami Landobeluak.

Malemi Lambe'susu unnallianni pao lako Aan. Nakandemi Landorundun, naronnosammi tu bukunna.

Nakuami Mendurana: "La muben siara'ka te padangmu kutananni pao?"

Nakuami Landorundun: "Kuben siako, ke mutanan daoi lolok batu."

Natananmi Mendurana tu pao dao lolok batu, napaputu'i losso'. Nakuami: 'Mokako para' la kurampananni kapa', la suleoramo' lako liku nene'ku."

Ganna' tallu taunna, sulemi Mendurana dio mai tondokna.

Nakandemo Landorundun tu paona. Nakuami Mendurana, nakua:

22) Landobeluak is de parallel van Landorundun: De Langharige.

23) Zondong: mannetjesdier, haan, in d.t. man.

24) De zin van deze woorden en van de volgende regel is: hij verkoopt maar ijdele praatjes.

25) unnorong kaso ditamben, 1t1. drijven naar de echtverbintenis; kaso ditamben, of kaso sitamben, 1tl. dwars op elkaar liggende daksparren. 
Ik heb geen schuldvordering, geen debeteis van lang her.

Haar kom ik aanschouwen, lang haar kom ik gadeslaan, dat het midden van de zee verlicht, glanst over het schuim. Daarvoor deed ik een lange tocht, daarvoor kwam ik van verre".

Landorundun zeide, de woorden van Landobeluak 22) waren:

"Een praatjesmaker is deze Man, 23)

hij spreekt over kleefrijst, gekookt in een blad van de bamboe betung, maar het is er niet, 24)

hij spreekt over een biezen tas, maar die is leeg.

Op welke herinnering doelen uw woorden, komt uw geheugen nog toe, ginds in het hoogtepunt van het uitspansel, het zenith der goden, dat zich als een rijstmesje welft?" Mendurana zeide:

"Deze verheven Vrouwe spreekt loze taal, niet geloofwaardig is deze Edele.

Blijkbaar is zij toch hier, het is toch echt door mijn ogen aanschouwd, ik heb het bij het aanschouwen gezien.

Ik wil met $u$ huwen, met $\mathrm{u}$ mij in de echt verbinden". 25)

Landorundun knikte van neen, Landobeluak weigerde.

Lambe'susu ging manggavruchten voor zich kopen in Aan. Landorundun at ze, ze liet de pitten naar beneden vallen.

Toen zeide Mendurana: "Wil mij van uw grond geven, dat ik er manggabomen plante".

Landorundun zeide: "Ik wil ze u wel geven, als gij ze plant boven op de top van de rots".

Mendurana plantte de manggabomen boven op de top van de rots en omwikkelde ze met aarde. Hij zeide: "Wanneer gij nog steeds weigert dat ik $\mathrm{u}$ huw, dan keer ik weer terug naar de diepe kolk van mijn voorvaderen".

Toen drie jaren vol waren, keerde Mendurana terug uit zijn land. Landorundun had van zijn mangga's gegeten. Daarop zeide Mendurana: 
'Minda ungkande paoku, umpearang dadekoku sola tanan-tananangku?

Pasuleanna' paoku, balikanna' dadekoku, pasule lakoi to'na, popa'baruku rara'i, popa'eteng bulaanni."

Nakua Landorundun:

'Kuanniiko to mangkambi', sola to manglaa tedong."

Nakuami to mangkambi':

"Kuanniiko Landorundun, ia ungkande paomu, sola tanan-tananammu."

Ma'kadami Mendurana 1ako Landorundun, nakua:

"Iko ungkande paoku, umpearang dadekoku?

La kurampanniko kapa'."

Unnilingmi Landorundun, nokami Landobeluak.

Nakuami Mendurana:

"Kutampangampoko salu, kubala batuampoko, kusapan pangkalo' puang, anna sombo to rundunmu, mempaan lakka buamu."

Sombomi to rundunna, ma'naranmi Landorundun.

Nakuami Landorundun:

"Pong Tau, Pong Tau Allo, Pong Tiboong ri bisara, Pong Tau la kegagaran, kakei, kakei rompon, rebakki bala batummu.

26) Heer Zonnemens heeft de betekenis van: Heer, die alles vermag. De zegsman zei erbij dat het hier, in de liefkozende woorden van Landorundun, de bijnaam is voor Mendurana.

27) Tiboong bevat een vervloeking, zoals ook in de uitdrukking bendo' buaja voorkomt, 1t1. monsterachtig als een krokodil, vervloekt nog aan toe. Vgl. de woorden bendo' bulan in str. 1 van simbong podo' (The Chant, p. 71), die betekenen: ontzettend toch; de 1tl. ver- 
'Wie heeft van mijn mangga's gegeten, en zijn dorst gelest met mijn manggavruchten, en hetgeen ik geplant heb?

Geef mij mijn mangga's weer terug, breng mij mijn manggavruchten terug, breng ze terug naar hun stam, plaats de edele vruchten aan hun stelen, doe de prachtige vruchten in trossen hangen".

Landorundun zeide:

"Zeg het aan de herders, en de buffelhoeders".

De herders zeiden:

"Zeg het aan Landorundun, zij heeft uw mangga's gegeten, en hetgeen gij geplant hebt".

Mendurana zeide tot Landorundun:

'Hebt gij mijn mangga's gegeten, hebt gij met mijn manggavruchten uw dorst gelest?

$\mathrm{Nu}$ zal ik u huwen".

Landorundun knikte van neen, Landobeluak weigerde.

Toen zeide Mendurana:

"Ik zal u nog eerst de stroom afdammen,

ik zal er $u$ van afzonderen met een wand van steen, ik zal het water in de rivier van $u$ afhouden door een dam, opdat uw haren zichtbaar worden, tot aan uw hart en nog verder".

Toen werden haar haren weer zichtbaar en Landorundun sprak vleiend.

Landorundun zeide:

"Edele Heer, Heer Zonnemens, 26)

Heer, de Geweldige in uw gedragingen, 27)

Edele Heer, die een krachtig doorzettingsvermogen zal hebben maak kapot, maak kapot de vuilnis, 28)

breek af uw stenen wand.

taling is: een riviermonster of krokodil van lichte kleur; bulan zal hier misschien de ongunstige betekenis hebben die het heeft in tedong bulan: een albino buffel van lichte kleur. - In deze regels worden de honorifieke benamingen opgesomd, die Landorundun aan Mendurana geeft om hem gunstig te stemmen.

28) De zin van deze woorden is: werp weg al hetgeen niet goed is. 
Unniomo Manggoali,

Ma'dinmo Patodenmanik,

unnio sola gallangna,

ma'din sola balusunna."

Narangkeammi Mendurana tu salu natampangngi.

Nakuamo Landorundun:

'Ma'dinko kita kudonde',

kudonde'-donde' balangmu,

kusimporro' tumabangmu."

Narangkean tarru'mi Mendurana, tae'mi sakke nairu' Landorundun.

Ma'kadami Landorundun, nakua: "O indo', laomoko unnalanna', sakke malino, uai to'do sipissan dao ui'na padang di Sesean. Messiraunami Mendurana lao ullo'po'i tu lampana. Tae'mi sakke nairu' Landorundun.

Nakuami Landorundun:

"Pong Tau, Pong Tau Allo,

Pong Tiboong ri bisara,

Pong Tau la kegagaran,

benmo'i sakke malino

uai to'do sipissan.

Unniomo Manggoali,

ma'dinmo Patodenmanik,

unnio sola gallangna,

ma'din sola balusunna.

Palengkarammo' bubungku,

sakkangammo' turunangku,

sola tanan-tananangku."

Nakabe'mi tu bubunna, tipalempemi bubunna. Naangka'mi langngan lembang, malemi naulang rampanan kapa' langngan Bone.

29) Manggoali is een andere benaming van Landorundun.

30) Patodenmanik is een erenaam van Landorundun en betekent: $\mathrm{Zij}$, die haar kralensieraad goed zichtbaar draagt.

In de simbong-zang, zoals die op het bua'-feest in het landschap

Pangala' wordt gezongen, wordt gesproken van:

str. 211: De lieden, die de Sesean opgaan, boven op de rug van het gebergte Tean, en de Lindomabusa, de drie putten bespiedende, de waterleiding, waar telkens een druppel uitvalt, het water, dat afwisselend uitvloeit.

212: De put van Manggoali,

de put van Patodenmanik,

de wel van de vorsten,

ginds in de ruimte onder aan de Sesean. 
Manggoali 29) zegt ja,

Patodenmanik 30) is bereid,

zij zegt ja tezamen met haar geelkoperen enkelring,

$z i j$ is bereid tezamen met haar armband van witte schelp. 31)

Toen maakte Mendurana de rivier voor haar droog, die hij had afgedamd.

Landorundun zeide:

"Ik ben bereid $u$ wat te vleien,

ik speel wat met uw streken, 32)

ik spot wat met uw 1isten. 33)

Mendurana ging regelrecht aan het droog maken, Landorundun had geen water meer om te drinken.

Toen zeide Landorundun: "O moeder, ga helder water voor mij halen, water dat telkens eens druppelt daar boven in de plaats onder aan de Sesean". Toen ging Mendurana zich door een toverkunst onzichtbaar maken 34) en maakte een gat in haar bamboegeleding. Landorundun had geen water om te drinken.

Landorundun zeide:

"Edele Heer, Heer Zonnemens,

Heer, de Geweldige in uw gedragingen,

Edele Heer, die een krachtig doorzettingsvermogen zal hebben, geef mij helder water,

water dat telkens druppelt.

Manggoali zegt ja,

Patodenmanik is bereid,

zij zegt ja tezamen met haar geelkoperen enkelring,

$z i j$ is bereid tezamen met haar armband van witte schelp.

Verplaats mijn bron voor mij,

hef mijn put voor mij op,

tezamen met mijn aanplant".

Hij strekte de hand uit naar haar bron, toen helde haar put over. Hij hief haar naar boven in de prauw. Daarop gingen zij opwaarts naar Bone vanwege de echtverbintenis.

213: Wij maken er aangekomen een goot voor, wij maken voor ons een overgang van stenen, het zal hier een waterplas zijn, het zal een zee zijn, die ons omringt.

31) De zin hiervan is, dat Manggoali met al wat zij aan sieraden aan heeft, geheel en al toestemt Mendurana te huwen.

32) Kudonde'-donde' balangmu, 1t1. ik speel met uw longen.

33) kusimporo' tumabangmu, 1t1. ik knoop uw maag geheel en al dicht.

34) messiraunammi: "zich geheel en al onzichtbaar maken door een toverkunst" is een afleiding van maraun: omfloerst van de ogen. 
Undimi indo'na, Lambe'susu, sae dao Tiroan; unnosok guntu'na rokko batu, nakua: "U! ... male tonganmo anakku nabaa Mendurana. (Dao sia totemo tu lalan guntu'na.) Male rokko Pongsake. Napasapa'imi bongi Mendurana langngan, nakua: "Da naundi urrundu'i, ..." Disangami 'Matabongi" tu dao Pongsake.

Landa'mi langngan padang di Bone Mendurana, turumi lan rampanan kapa'. Torro to Sallangmi dao padang di Bone. Iamoto naranduk ussallang bai (tae' nakande duku' bai).

Undadiammi Batara Goa. Kasalle dadinna Batara Goa, sae nenne'mi unnika' to matuanna, apa tae' ditiro ke saei, belanna to sola deatapa.

Iatu liangna Lambe'susu sola Embatau dao Sesean, tae'mo ditiro, nasapu ade' Batara Goa, anna kakemunan.

Iatonna male tu Landorundun sola Mendurana langngan Bone, male ia sule lako Seko tu Salokang, ambe'na.

Male pole'omi ia Lambe'susu langngan Sesean, sirampanan kapa' Embatau. Dadimi anakna lima: 1. disanga Marimbunna; 2. disanga Dandebulaan; 3. disanga Ponnorara'; 4. disanga Allotikini'; 5. disanga Suloara' Undi.

1. Male Marimbunna rokko Tikala, naulang rampanan kapa' lako Buntukendek, nadadi To Karurung.

2. Male Dandebulaan lako Pa'bosok.

3. Male Ponnorara' lako Tinimbajo, sirampanan kapa' Puolangi'.

4. Male Allotikini' sirampanan kapa' Pong Sambira daa $\mathrm{Pa}$ 'padanunan, nadadi Patana'langi'. Male Patana'langi' rokko Pangli, sirampanan kapa' anakna Ura'padang, nadadi: I. Daddo' male rokko Deri, sirampanan kapa' Tumba' Rura, iamo nadadian Ne' Rose' sia Lotongtara sia Bulubassi. II. Dadi To Mangli', male rokko Parinding.

5. Suloara', iamo untorroi padang di Sesean.

35) Buntu Kendek is een plaats in het landschap Tikala, evenals het in de volgende $z$ in genoemde Pa'bosok. 
Het gebeurde later, dat haar moeder, Lambe'susu, boven in Tiroan kwam; zij dreef haar knie in een steen, zij zeide: "Ja! Mendurana heeft mijn kind werkelijk weggevoerd". (Daarboven is echt de afdruk van haar knie.) Zij ging nederwaarts naar Pongsake. Mendurana legde de duisternis bovenwaarts als scheidingswand tegen haar en zeide: "Dat zij niet achterna volge". ... Pongsake daarboven werd: "Matabongi" (= Het Centrum der Duisternis) genoemd.

Mendurana ging regelrecht naar het Bonese Land, hij bleef standvastig in het huwelijk. Hij was een Moslim in het Bonese Land. Daarom begon hij een afkeer te krijgen van het varken (hij at geen varkensvlees).

Hij verwekte Batara Goa. Toen Batara Goa groot geworden was, kwam hij geregeld offeren bij het graf van zijn voorouders, maar men zag hem niet, wanneer hij kwam, want hij behoorde nog tot de groep der goden.

Het rotsgraf van Lambe'susu en Embatau op de Sesean is niet meer te zien, Batara Goa was er, naar men zegt, met de hand langs gestreken, zodat het aan alle zijden bedekt is.

Toen Landorundun met Mendurana naar Bone was gegaan, ging Salokang, haar vader, terug naar Seko.

Lambe'susu ging op haar beurt de Sesean op en huwde met Embatau. Zij kreeg vijf kinderen: 1 . met de naam Marimbunna; 2 . met de naam Dandebulaan; 3. met de naam Ponnorara'; 4. met de naam Allotikini'; 5. met de naam Suloara' Undi.

1. Marimbunna ging benedenwaarts naar Tikala, de echt verbond hem naar Buntukendek; 35) toen werd To Karurung geboren.

2. Dandebulaan ging naar Pa'bosok.

3. Ponnorara' ging naar Tinimbajo en huwde met Puolangi'.

4. Allotikini' ging huwen met Pong Sambira in het Noorden in Pa'padanunan; toen werd Patana'langi' geboren. Patana'langi' ging benedenwaarts naar Pangli en huwde met de dochter van Ura'padang; toen werden geboren: I. Daddo', hij ging nederwaarts naar Deri en huwde met Tumba' Rura, zij verwekten $\mathrm{Ne}^{\prime} \mathrm{Rose}^{\prime}$ en Lotongtara en Bulubassi. II. Geboren werd To Mangli', hij ging nederwaarts naar Parinding.

5. Suloara', hij verbleef in de streek van de Sesean. 
H. van der Veen - 978-90-04-28716-7 Downloaded from Brill.come4/26/2023 02:54:12PM via free access 


\section{Inleiding}

Na het overlijden van Puang Tarongko, de vorst van het rijk Ma'kale, een der drie rijken van de Tallu Lembangna, de Federatie van drie gebieden, onder het bestuur staande van een der leden van de familie der puang, werd een uitvoerig dodenritueel van de overledene verricht.

$\mathrm{Na}$ de beëindiging daarvan werd zijn zoon Ranteallo, met de titel Puang Tondon, als zijn opvolger aangewezen. De investituur van deze Puang Tondon had plaats in een plechtige bijeenkomst van de bewoners van het rijksgebied op het terrein waar het tweede gedeelte van het dodenritueel voor zijn vader was verricht.

De Puang van het rijksgebied Sangalla', Laso' Rinding geheten, sprak daarbij het investituursformulier uit, staande op de bala'kajan, het hoge platform, van waarop de plechtige toewijzing van de voor de verschillende adatfunctionarissen bestemde delen van het vlees van de geslachte buffels, geschiedt. De hier volgende tekst, Tangdona sulze gajangna Buzlu Matua ("De eedzwering van de majestueuze opvolger van Bullu Matua") bevat het toen uitgesproken formulier, zoals het later door Puang Sangalla' zelf nogmaals werd gereciteerd om het opschrijven mogelijk te maken.

Bullu Matua is de voorvader van de puang-dynastie van Ma'kale; zijn andere naam luidt Pasolang Boro. Palodang is de voorvader van de puang-dynastie van Sangalla' en Paetong de voorvader van die van Mengkendek. Deze drie voorvaderen zullen wel afstammen van de mythische figuur van Tamborolangi', een to manurun, een uit de bovenwereld op aarde neergedaalde figuur.

Tangdo heeft de oorspronkelijke betekenis van vervloeking; hier wordt het gebezigd in de betekenis van eedzwering, welke een bedreiging bevat voor degene die de eed zou breken. 
Heeee!

1 Iko anggenna to lolong ma'kekeran bassi lan rante kalua', makalima'na to limbong ma'punti disasa' lan tandung kalonaran.

2 Naperendenni pote dibolong, napebalajanni tintin dibarata.

3 Anggemmu matallo matampu', makalima'mu, pollo'na, ulunna.

4 La tumanan rampa'ko talinga duammu, la lumedanko pili' patomalimmu.

5 Angku rundunan tana'pa aluk lolong dilangi', angku tete batu katonanpa sangka' turun dibintoen.

6 Aluk napondok tengko Puang Matua lan tangngana langi', sangka' napamangka salaga To Kaubanan lan dasa' to paonganan.

7 Tonna tiangka' bate lentekna Tamborolangi', tonna tirimba pessoenanna Datu Muane,

8 napokambutu' maringan Ambe' To kumombongna, napobi'ti' telang 1oli Ambe' To manggaraganna.

9 Tang umpolalan ba'bana langi', tang umpolambanan pentiroan to palullungan.

1 Zolong, 1tl. vloeien. ma'kekeran bassi, $1 t 1$. op ijzer bijten; de uitdrukking is ontleend aan het oude gebruik om voordat men ging eten op een stuk ijzer te bijten. Dit deed men uit vrees, dat men het rouwgebruik van het niet eten van rijst (maroo') niet in acht zou genomen hebben voor een familielid, dat in den vreemde was overleden zonder dat men het wist. ma'punti disasa', 1tl. in stukken gesneden pisangvruchten eten gedurende de tijd, dat men maroo' is, geen rijst eet, maar knollen, pisang enz.

2 pote: band van gevlochten garen met een kwastje aan het eind, waarin kralen zijn gestoken; deze band wordt gedragen door mannen, die het rouwgebruik van het niet eten van rijst in acht nemen. Bij een dergelijk rouwgebruik dragen vrouwen als pote een donkergele of zwarte à jour bewerkte doek met franjes aan het benedeneinde; aan het boveneinde loopt deze doek puntig toe om er het hoofd in te steken. tintin = sissing: ring.

4 Zumedan $=$ umpalidan: neigen, schuin houden om te luisteren.

5 tana', 1tl. paaltje, staak om iets vast te stellen, vaak als grensteken gebruikt.

mundunan, 1tl. langs de gehele lengte gaan van, bv. van een oever. batu katonan, 1t1. grenssteen. 
Attentie toch!

$1 \mathrm{Gij}$ allen, die op de wijde vlakte zijt gekomen om deel te nemen aan de rouw,

die tot de laatste toe op het ruime veld zijt samengestroom, het rouwgebruik van het niet eten van rijst in acht nemend.

2 Die als leidsman hebt de zwart gemaakte rouwband,

die als gids hebt de zilveren ring met een stukje zwart weefsel omhuld.

$3 \mathrm{Gij}$ allen in het Oosten, het Westen, tot de laatste toe, in het Zuiden, in het Noorden.

4 Neigt stil uw beide oren,

houdt uw beide slapen schuin overgebogen om te luisteren.

5 Opdat ik nog in vaste volgorde van het begin tot het einde de adatregelingen meedeel, die uit de hemel zijn gekomen, opdat ik nog de bepaalde orde der grenzen betredend de adatbepalingen uiteenzet, die van de sterren zijn neergedaald.

6 De adatregelingen in vaste vorm ingesteld door Puang Matua in het midden van het uitspanse1, de adatbepalingen definitief verordend door To Kaubanan in het

Noorden van het al bedekkende.

7 Toen Tamborolangi' zijn schreden verhief, toen Datu Muane zijn armen slingerend liet zwaaien,

8 bezigde Vader Schepper hem als zijn afgezant, bezigde Vader Formeerder hem als boodschapper.

$9 \mathrm{Hij}$ nam de poort van de bovenwereld niet als weg, hij nam het venster van het al omhullende niet als de plaats, waar hij langs ging.

6 To Kaubanan: de met grijsheid getooide.

7 bate lentek: wijze van gaan. Tamborolangi' is de voorvader der Puang-geslachten; hij is in de voortijd uit de bovenwereld op de rots Kandora, in het landschap Mengkendek, neergedaald.

8 napokambutu' maringan, 1tl. hij bezigde hem als lichte hiel, vgl. de dichterlijke uitdrukkingen napolentek maringan: hij bezigde hem als lichte voet, en napobi'ti' telang Zoli, 1t1. hij bezigde hem als een kuit, licht als een stuk bamboe, dat in een spel tussen twee bamboelatten wordt geklemd en dan moet worden weggewipt. 
10 Untongkonni banua ditoke', unnesungi pungsa pata'na tondok dianginni.

11 Umpokinallo aluk sanda saratu', umpobokong kalambanan sangka' sanda sangsamma'.

12 Untongkonni alla'na tana, unnesungi pararra'na to kedaenan.

13 Pakitami mata ulunna lan banua ditoke', palingi'mi tondon karopokna lan tondok dianginni.

14 Untiromi toding pelangiran kendek diliku lan Batu Sapa', ullingi'mi baru' tang silambanan lan di Pangindanan.

15 Tiangka'mi bate lentekna la rumampan kapa', tirimbami pessoeanna tuma'bak passullean allo.

16 Sombo randan di pudukna Datu Baine, meosik tanda masiang, nakua:

17 'Umbara aluk mupokinallo di lalan, e Tamborolangi' ammu la rumampan kapa', tiapara sangka' mupobokong kalambanan, ammu la tuma'bakra passulean allo?"

18 Nakua: "Aluk napondok tengko Puang Matua lan ba'tangna langi', sangka' napamangka salaga To Kaubanan lan dasa' to paonganan."

19 Natimang pakkanmi pole Datu Baine randan dipudukna Tamborolangi', nasarande kaeranmi baru' tangsilambanan tongka' dililana Datu Muane.

10 Volgens de overlevering daalde Tamborolangi' eerst op de rots Kandora neer en ging toen het in het uitspansel hangend huis bewonen en daalde neer in Ullin, op een berg in het landschap Banga. In de overleveringen in de Oostelijke landschappen van het Rante paose wordt ook gesproken over een banua ditoke': 'het huis, dat opgehangen is"; dat huis zweefde heen en weer boven de streek Rante $\mathrm{Aa}^{\prime}$, op het Pedamaran-gebergte en diende als woning voor Salikunna, een der voorouders van die streken.

12 kedaenan, 1t1. land-hebbend.

13 tondon, 1t1. rand van een steilte. karopok, 1t1. schedel.

14 Batu Sapa' wist J. Tammu niet goed thuis te brengen; ik vermoed, dat hier gedacht moet worden aan Sappang Dewata, waar volgens de overlevering Sanda Bilik, de echtgenote van Tamborolangi' uit een rotsblok was te voorschijn gekomen, liggend voor de uitmonding van de Salu Tapparan in de Sa'danrivier, zie Nobele (1926), p. 122. Sapa' heeft de betekenis van een bewijsteken van een eed. baru' tang silambanan: niet dooreenlopende scheiding, scheiding van welke de haren niet door elkaar lopen, niet verward zijn; dit is de dichterlijke benaming van een vrouw van hoge stand, vgl. simbolong manik: haarwrong, glanzend als kralen, Zokkon Zoerara': haarknot, neerhangend als een gouden halssieraad, The Merok Feast, p. 24v., B, str. 30 . 
$10 \mathrm{Hij}$ zette zich in het huis, dat opgehangen was,

hij ging zetelen in het omgebogen uiteinde van de lengtebalk van het huis in het oord, waar de wind overheen waait.

$11 \mathrm{Hij}$ had de volledige honderd adatregelingen tot leeftocht,

hij had de volledige geweldig vele adatbepalingen als teerkost op de weg.

$12 \mathrm{Hij}$ vestigde zich in het tussengebied van de aarde,

hij zette zich neer in de tussenruimte van hetgeen, waar land was.

$13 \mathrm{Hij}$ kon in het hangende huis de kern van het noordelijk gebied zien,

hij kon met aandacht in het oord, waar de wind overheen waait, de rand van de bovenstreken er van beschouwen.

$14 \mathrm{Hij}$ zag het spoor van een haarwassing boven gekomen in de waterkolk op Batu Sapa',

hij aanschouwde een edele in Pangindanan.

$15 \mathrm{Hij}$ verhief zijn schreden om een huwelijk te sluiten,

hij liet zijn armen slingerend zwaaien om een echtverbintenis aan te gaan.

16 Duidelijk kwam het van de rand der lippen van Datu Baine, zij vroeg op heldere wijze en zeide:

17 'Welke adatregelingen hebt gij als leeftocht op de weg om een

huwelijk te sluiten, Tamborolangi',

wat voor adatbepalingen hebt gij als teerkost op de weg om een

echtverbintenis aan te gaan?"

$18 \mathrm{Hij}$ zeide: "De adatregelingen in vaste vorm ingesteld door Puang

Matua in het zenith,

de adatbepalingen definitief verordend door To Kaubanan in het

Noorden van het al bedekkende."

19 Datu Baine nam dan als antwoord aan, de woorden komende van de rand der lippen van Tamborolangi',

de edele Vrouwe nam het door Datu Muane gesprokene vast in zich op.

15 tuma'bak = tumenden. passullean allo, 1tl. de vervanger van de dag.

$17 \mathrm{Vg1}$. The Merok Feast, p. 78, B, str. 380vv.

18 ba'tangna langi', 1ti. het binnenste van het uitspansel.

19 tongka' dizilana, 1t1. omhoog wippend op zijn tong. nasarande is een nevenvorm van narande: zij hield op de palm van de hand; in Pangala' luidt deze vorm in d.t. nasarandek.

kaeran, nevenvorm van kaberan: toestel bij het weven gebruikt om de scheringdraden om en om uiteen te houden om de inslag er vast in te zetten; nasarande kaeranmi is een verbale samenstelling, waarin het tweede lid het eerste bepaalt. 
20 Manda'mi lan tampo limbongna rampanan kapa', ditono' tangke pelalan lauran pekanna bisara.

21 Dadimi anakna rampanan kapa' karua naria sukaran aluk, kombongmi bongsunna pantan sia'paran nasaladan lauran pekanna bisara.

22 Titale' tinggimi lako matallo matampu, tiembon pinamasak lako pentutuan lipu sanda kalua' .

23 Randukmi dikataku' puang aluk lolong di langi', nenne'mi dikatangka deata sangka' turun dibintoen tasak.

24 Tuo balo'mi lako matallo matampu', tumbu kumuku'mi lako pentutuan lipu sanda kalua'.

25 Taria tannun to torro to lino, tasaladan talikuran to unnesung mentau mata.

26 Apa tae' ia to natampa to sekong sukaran aluk sangbara' padang, tang denpa nakombong tau pandak lauran pekanna bisara.

27 Tontong tasiosso'i to torro to lino, tu'tuan tasiturananni to unnesung tau mata.

28 Tarundu' bate lalanna te allo totemo, tapanglola baan tondon karasanna te kulla' te marassan.

29 Ulang rara'na te allo totemo angku tongkonni bala'kajan duku' te sulle gajangna Palodang di Kaero, situru' lentong sili' sarapangna Paetong lan di Mengkendek.

21 bongsu: jongste kind, in d.t. kind.

22 tinggi: rode kraal. pentutuan: het gedeelte van een weg, dat geregeld betreden wordt. pinomasak = masak, $1 \mathrm{tl}$. donkergele kraal van hoge waarde, vgl. tasak.

23 tasak: rijp, zuiver, gedegen, meest van goud gezegd, vgl. masak.

28 tondon karasanna, 1 tl. de rand van hun horens.

29 Kaero is de naam van het voorvaderhuis van de puang-geslachten van Sangalla'.

situru' ientong, 1tl. elkaar volgend als palen, die in een rij staan. 
$20 \mathrm{Zij}$ bleven vast op de dijk van het meer van het huwelijk, trede voor trede zoals de sporten van een ladder werden de juiste trappen der bepalingen van de adatvoorschriften betreden.

21 Toen werden acht kinderen uit het huwelijk geboren, gekoesterd door de adatverrichtingen,

toen kwamen kinderen van hen ter wereld, vier van elke kunne, behoed door het trapsgewijs betreden van de bepalingen der adatvoorschriften.

$22 \mathrm{Zij}$ verspreidden zich op majestueuze wijze naar het Costen en het Westen,

zij golfden op sublieme wijze uit naar de vaste wegen van de uiterst ruime oorden.

23 De uit de bovenwereld gekomen adatregelingen werden als goddelijk geëerbiedigd,

de van de geelglanzende sterren neergedaalde adatbepalingen werden voortdurend gevreesd als goden.

$24 \mathrm{Zij}$ leefden voorspoedig Costwaarts en Westwaarts,

zij gedijden gezegend gaande naar de vaste wegen van de uiterst ruime oorden.

$25 \mathrm{Wij}$ droegen zorg voor de mensen van deze wereld,

wij beschermden de in menselijke gestalte verblijvenden op de wijze van lendejukken.

26 Maar er werden geen gebrekkige lieden ter wereld gebracht door de adatregelingen, even oud als de aarde,

niet was het, dat onvolkomen mensen geformeerd werden door de juiste trappen van de adatvoorschriften.

27 Steeds volgden wij mensen van deze wereld elkaar in geregelde volgorde op,

voortdurend wisselden wij als nog levende mensen verblijvend elkaar af.

28 Wij volgen op de huidige dag hun wijze van doen,

wij sluiten ons in de tijd van heden als volgelingen aan bij hun machtige verordeningen.

29 Het is de kostbare band met de huidige dag, dat ik verblijf op het platform van de vleesverdeling als opvolger van de edele heer van Palodang in Kaero;

tezamen met de doorluchtige plaatsvervanger van Paetong in Mengkendek. 
30 Tu la disukaranni kinallo lalanna lan rante kalua', la napokinallo ilalan sau' palangkana langi', la napobokong kalambanan sau' pongkuriona dao dasa' to paonganan.

31 Dipilean ma'gallangna tedong, ditonnoran ma'balusunna karambau.

32 Baju sielle'na sukaran aluk, dodo' sangkalamma'na lauran pekanna bisara.

33 Tu belanna nalambi'mi ia kanna bunu'na te Kalindobulanan, nadete'mi pa'ongan daoanna te Kabarrealloan.

34 La lumokkon lalanna te penaa ma'bulu podong lan batang di kalena, la natimang pakkan Puang Matua Ulu lan tangngana langi'.

La lumu'pi'mo pa'gulinganna te sunga' mentangke a'rari lan tondon to batangna,

la nasarande kaeran To Kaubanan dao masuanggana to palullungan.

35 Bannang bulajanna angku esungi lempo bumarran te sili' sarapangna

To Kabarrean kulla' lan Tammuanbida', sibarru barana' sule gajangna Paetong lan di Mengkendek.

36 La unturo ta'ba sulle gajangna Bullu Matua lan di Ma'kale, la undullu pela'pak sili' sarapangna Pasolang Boro lan to Bamban Bukulau'.

30 palangka, 1t1. verhoogde vloer aan de Oostzijde van het huis. "voor hem", d.i. de overleden puang; "de leeftocht", d.i. het aantal buffels op het dodenritueel voor hem te slachten op zijn weg naar het dodenrijk. Het woord pongkuriona wist de Heer Tammu niet te verklaren.

31 ma'gallangna tedong, $1 \mathrm{t} 1$. de geelkoperen enkelring dragende der buffels; ma'balusunna karambau: de armbanden van witte schelp dragende der karbouwen.

33 kanna bunu'na, 1tl. de bepaalde maat van de band, waarmee de rijstbossen bij de oogst gebonden worden. Kalindobulanan, 1t1. Die glanst als het aanschijn van de maan, Kabarrealzoan, 1tl. Die schittert als de Zonnestralen, titels van de puang.

34 het woord penaa is in dit verband vertaald met "levensadem", vgl. verderop de parallel sunga': "levensgeest". Zumokkon Zalanna, 1tl. zijn weg omvouwen; hier is de betekenis: op zijn weg terugkeren, naar zijn oorsprong terugkeren, d.i. zullen sterven.

Puang Matua U1u, 1tl. de Vroegere Puang Matua; naar de theogonie der Sa'dan-Toradja is er een vroegere Puang Matua: Puang Matua Dolo (hier Puang Matua Ulu genoemd) en een latere Puang Matua: Puang Matua Undi. (Mededeling van de heer Tammu.) pa'gulingan: weg, die men heen- en teruggaat. 
30 Om voor hem de leeftocht af te meten op zijn weg op de wijde vlakte,

om als teerkost te gebruiken op de weg Zuidwaarts naar het vertrek van het uitspanse1, om als leeftocht te gebruiken op het pad Zuidwaarts ... boven in het vertrek van het albedekkende.

31 Voor hem zijn de kostbaarste buffels gekozen, voor hem zijn de waardevolste karbouwen uitgezocht.

32 Een baadje passend bij de adatregelingen, een sarong in harmonie met de juiste trappen van de adatvoorschriften.

33 Want deze Die glanst als het aanschijn van de Maan heeft bereikt het vastgestelde van zijn levensduur,

deze Die schittert als de Zonnestralen is aangekomen op zijn hoge bes temming.

34 Zodat deze levensadem, fijn als de haartjes van de vliegende mier in zijn lichaam, op zijn weg zal terugkeren,

dat Puang Matua de Vroegere in het midden van het uitspansel hem vergelding schenkende zal aannemen.

Zodat deze levensgeest, fijn geleed als de termiet in het gebied van zijn lichaam, op de door hem afgelegde weg zal terugkeren, dat To Kaubanan in het allerhoogste van het al omhullende hem vast in ontvangst zal nemen.

35 Dat is de gulden reden, dat ik mij bevind op het platform met een vleesgeur, ik de majestueuze opvolger van hem Die schittert als de Zonnestralen in Tammuanbida',

in tweeheid als bijeenstaande waringinbomen verbonden met de majestueuze vervanger van Paetong in Mengkendek.

36 Om selectief aan te wijzen de majestueuze opvolger van Bullu Matua in Ma'kale,

om met een staf de majestueuze opvolger aan te duiden van Pasolang Boro in Bamban Bukulau'.

35 Zempo bumarran: "het platvorm met een vleesgeur" is een dichterlijke benaming van de bala'kajan (zie Inleiding).

Tammuanbida' is een honorifieke benaming van het rijk Sangalla'.

36 unturo ta'ba, 1t1. aanwijzen door af te kappen. pela'pak, 1t1. stokje door buffelhoeders gebruikt om de buffels mee te slaan. Bamban Bukulau': naam van het rijk Ma'kale. 
37 La napentionganni to ma'duang salu, la napellalundunni to ma'kalo' simisanan.

$38 \mathrm{La}$ natanan napakalindo-bulanan lan padang di Ma'kale, la naranduk napakabarre-alloan lan to Bamban Bukulau'.

$39 \mathrm{Na}$ tontong ma'lajuk lamba' lan padang di Ma'kale, tang pakajun bimbang, na tu'tuan ma'tarangsu barana', tang pasembe' beko-beko.

40 Ianna la tumambuk ma'duang papa', tang la urrundu' alukna

Tamborolangi', la napomanua lullu', ianna la sumembe' ma'tallu inaa, la napobeta manurun.

$41 \mathrm{Ke}$ tang la umpanglola baan pa'palumpunna Datu Muane, ke la umpobaine kura'i sarong bulajanna Tamborolangi' ke la umpododo' tiamballungi ta'dung bulajanna Datu Muane,

42 ke la umpenukaranni ampa' bulajanna, ke la umpakesolonni allonan disura' seleng,

43 tang la pangaku-akuan dio batang di kalena, tang la pangore-orean dio tondon to batangna,

44 la natina' rantang basse dipaturun guntu', la narebong tana' pandan dipala'to galugu.

$45 \mathrm{~Pa}$ iamo natanan tallang Puang Matua Ulu lan tangngana langi', napariai basse dipaturun guntu', tenmo to naranduk bulo ala' To Kaubanan lan dasa' to paonganan.

37 to ma'duang salu: de lieden van de beide rivieren, d.i. zij die ieder een eigen riviergebied hebben, t.w. de lieden van de vrije stand en van de stand der horigen.

to ma'kalo' simisanan is de parallel van to ma'duang salu, ook de stand der vrijen en de stand der horigen aanduidend.

39 pakajun bimbang, 1tl. ongelijk over de schouder dragen. pasembe' beko-beko, 1tl. in een doek dragen, die heel scheef over de schouder gehouden wordt.

40 ma'duang papa', 1t1. in twee lagen. nopomanua Iu $Z Z^{\prime}$ ', 1 tl. het zou voor hem zijn als het vastgetreden gif uit de wortel van een bepaalde klimplant, met welks sap vissen bedwelmd worden. beta: bezit; nopobeta heeft in dit verband de betekenis van: hij heeft als bezit hetgeen tegenspoed, vloek aanbrengt.

41 tiamballung, $1 t 1$. onder het lopen het lichaam heen en weer laten bungelen.

"als gouden zonnehoed" en "als gouden zonnescherm" hebben hier de betekenis van: als vorstelijke gemalin.

43 naore: hij houdt op met.

45 nopariai, 1 tl. hij heeft het op de schoot gezet van. 
37 Opdat bij hem zouden schuilen de lieden van de beide rivieren, bij hem beschutting zouden zoeken de lieden, die ieder een eigen bevloeiingskanaal hebben.

38 Opdat hij zou vaststellen en handhaven de status van majesteit in het gebied van Ma'kale, opdat hij zou instellen en handhaven de status van vorstenglorie in het gebied van Bamban Bukulau'.

39 En steeds verheven zou zijn als een ficus-boom in het gebied van Ma'kale, zonder de een boven de ander voor te trekken, en voortdurend hoog in status zou zijn als een waringin zonder scheve praktijken toe te passen.

40 Indien hij iets dubbelzinnigs zou koesteren, en niet de adatregelingen van Tamborolangi' zou volgen, dan zou het hem tot een vastzittend verderf zijn, indien hij in drieërlei gezindheid leiding zou geven, dan zou hem dat van geslacht op geslacht tot een kwaad doend bezit zijn.

41 Wanneer hij niet als een parkiet de goed bewaarde traditie van Datu Muane zou volgen, wanneer hij door hartstocht gedreven als gouden zonnehoed van Tamborolangi' een vrouw zou nemen, wanneer hij zo maar losweg als gouden zonnehoed van Datu Muane een vrouw zou nemen,

42 wanneer hij zijn gouden mat zou trachten te ruilen, wanneer hij het hoofdkussen met seleng-motief bestikt, zou trachten te verwisselen,

43 en het niet in zijn innerlijk als overtreding zou bekennen, en er zich in zijn binnenste niet om bekommert,

44 zou hem heel hard treffen de vervloekingseed, die als de donder wordt neergelaten, zou hem heel zwaar breken de erfelijke overeenkomst, die als een onweersflits zal neerkomen.

45 Want dit heeft Puang Matua de Vroegere als een bamboe in het midden van het uitspansel geplant en het onder bescherming gesteld van de vervloekingseed, die als de donder wordt neergelaten,

zo heeft To Kaubanan het in de grond gezet als een dunne bamboe met lange geledingen in het vertrek van het al bedekkende. 
46 Nalao langi' situru' aluk sanda saratu', naturun di bintoen tasak sipanglola baan lauran pekanna bisara sanda sangsamma'.

47 Ditodon tampomi basse kasalle, dilampin batu katonan pandan dipamaroson.

48 Ditananmi sulle gajangna Bullu Matua lan di Ma'kale, pada ditanan tengko batunna lan di Kamali.

49 Dirandukmi sili' sarapangna Pasolangboro, pada dilammak batakan tang marapona.

50 Sitinti rara'na sullena Palodang lan di Sangalla', sangtende' batu bulaan sili' sarapangna Paetong lan di Mengkendek.

51 Iamo ditanan kalindo-bulanan, diranduk kabarre-alloan.

52 Innallonni mamma' panganna rara'na Tamborolangi', untulangdenni matindo pa'palugpun bulajanna Datu Muane.

53 Naposarong tangla' keallo kebongi, napota'dung kalelean kekulla' kekaroen.

54 Iamo rianna sangbara' padang, nasaladan talikuran sipamula ma'ti ditari'.

55 Belanna mangka napondok tengko Puang Matua Ulu lan tangngana langi', napamangka salaga To Kaubanan lan dasa' to palullungan.

56 Iamo dipakatua induk to anna dikataku' puang, tenmo to napabanno karurung anna dikatongka deata.

57 Ianna la umpokambuno paleleanni panganna rara'na to mellao langi', anna la umpota'dung doke-dokean pa'palumpun bulajanna Datu Muane,

48 "zijn ploeg van steen" heeft de betekenis van: zijn waardigheid, die onvergankelijk is. Dit is ook de betekenis van: "de niet vermolmde disselboom van zijn ploeg" in str. 49.

Kamali is een dorp in de nabijheid van de hoofdplaats Ma'kale aan de rechteroever van de Sa'dan-rivier.

50 sangtende', 1 tl. even zwaar bij het optillen.

56 induk heeft in dit verband de betekenis van het harde kernhout van de arenpalm.

banno karumung = banu' karumung: het zwarte kernhout van de arenpalm; napabanno kamuming: hij heeft ze als het zwarte kernhout van de arenpalm doen zijn.

57 kambuno: de waaierpalm, Livistona rotundifolia, welks bladeren dienden als zonnescherm voor de lieden van de hoge stand. De in beide leden van str. 57 metaforisch uitgedrukte gedachte is: Indien hij de macht, die hij op grond van de uit de bovenwereld neergedaalde inzettingen zou bezigen om ontzag voor hem zelf in te boezemen.

doke-dokean, 1tl. de eigenschap van hetgeen op een lans gelijkt bezittend. 
46 En die is uit de bovenwereld neergekomen te zamen met de honderd adatregelingen,

$z i j$ is neergedaald van de geelglanzende sterren, volgende op de wijze van een parkiet de juiste trappen van de geweldig vele adatverordeningen.

47 De zware vervloekingseed is in vaste opklimming geordend als trapsgewijze aangelegde sawahdijken,

het onder ede en met ritueel bekrachtigde overeengekomene is in een reeks vastgesteld als grensstenen op terrasvormige rijstvelden.

48 De vervanger van zijn edele Bullu Matua in Ma'kale is bevestigd, zoals zijn ploeg van steen in Kamali is ingedreven.

49 De doorluchtige opvolger van Pasolangboro wordt in zijn waardigheid gesteld, zoals de niet vermolmde disselboom van zijn ploeg is ingedreven.

50 Evenarend in majesteit de opvolger van Palodang in Sangalla', even hoog in glorieuze waardigheid als de mejestueuze opvolger van

Paetong in Mengkendek.

51 Zo is dan hij Die glanst als het aanschijn van de Maan bevestigd, hij Die schittert als de Zonnestralen in zijn waardigheid gesteld.

52 Zich neervleiend op de luisterrijke traditie van Tamborolangi', rustende op de glorierijke door Datu Muane ingezette overleveringen.

53 Die bezigt hij bij dag en bij nacht als een wijd geopende zonnehoed, die heeft hij overdag en in de nacht als een vermaard zonnescherm.

54 Die is de behoeder van het land even oud als zij zelf, die beschermt als een lendejuk het afgeperkte droge, dat dezelfde aanvang heeft als zij zelf.

55 Want Puang Matua de Vroegere heeft ze in vaste vorm als een ploeg ingesteld in het midden van het uitspansel,

To Kaubanan heeft ze in definitieve vorm verordend als een eg in het vertrek van het al omhullende.

56 Daarom is het dat ze ingezet zijn, oud als het hout van de arenpalm, opdat de goddelijke machten gevreesd worden,

zo is het, dat hij ze overoud heeft doen zijn, opdat de geesten geeerbiedigd worden.

57 Wanneer hij de luisterrijke overleveringen, die uit de hemel zijn neergedaald als overal uitgespreide bescherming zou hebben, dan zou hij de gouden inzettingen van Datu Muane als verdedigende beschutting hebben, 
58 la napomanua lullu' umposarong sarong bulajanna Tamborolangi', la napobeta manurun umpota'dung ta'dung kabusunganna Datu Muane.

59 Ke sitinti la napopaningoan sulle gajangna Bullu Gatua lan padang di Ma'kale, sanglindo susinna duka ke la sullena Palodang lan di Sangalla', sangrapang sitongananna ke la sili' sarapangna Paetong lan di

Mengkendek;

60 ke denni la pakajun bimbang lako to ma'duang salu, ke la pasembe' beko-bekoi lako to ma'kalo' simisanan;

61 iamo naria basse dipaturun guntu', iamo nasaladan pandan dipala' to galugu.

62 Natontongi Puang Matua Ulu lan ba'tangna langi', nadendenni To Kaubanan lan dasa' to paonganan.

63 Narampan di lino Tamborolangi' umpokinallo aluk napondok tengko Puang Matua, na mendemme' di daenan Datu Muane ussompo buntangan pananda bisara sanda sangsamma' .

64 Iamoto anna unniling tanduk sulle gajangna To Kalindo-bulanan, ke la di'pakura' tandukki aluk tuo balo'.

65 Iamo tibi'bi' telo-telo sili' sarapangna To Kabarre-alloan, ke la dipatirote bandanganni sangka' tumbu kumuku'.

58, 59 is duister. Dr. v.d. Veen vermoedde dat de tekst hier in de war geraakt is. (Red.)

63 ussompo: schrijlings op de schouder dragen. buntangan: volgelopen zijn.

64 unniling tanduk, 1t1. van neen knikken met de horens; het beeld is ontleend aan de gedragingen van een buffel, die met zijn kop tegen de grond schuurt en die dan weer van de grond opheft om de aarde, die op zijn horens zit weg te schudden als het ware zijn durf tonend.

65 telo-tezo: jonge spruiten aan de top van bomen en planten, hier: spits van een horen.

"op en neer geschud wordt gelijk een lans met geitenhaar", d.i. een statielans, die op en neer geschud wordt bij het uitvoeren van de krijgsdans. 
58 dan zou hem het dragen van de gouden zonnehoed van Tamborolangi' tot een vastzittend verderf zijn, dan zou hem het dragen van het magisch te ontziene zonnescherm van Datu Muane tot een van geslacht tot geslacht kwaad doend bezit zijn.

59 Indien evenredig daarmee de majestueuze opvolger van Bullu Matua er mee zou spelen in het gebied van Ma'kale, op dezelfde evenredige wijze ook, indien het de opvolger is van Palodang in Sangalla', desgelijks ook daarmede overeenstemmende, indien het de doorluchtige opvolger is van Paetong in Mengkendek;

60 wanneer het zou zijn, dat hij de een boven de ander zou voortrekken ten aanzien van de lieden van de stand der vrijen en der horigen, wanneer hij scheve praktijken zou toepassen jegens de lieden, die ieder een eigen bevloeiingskanaal hebben;

61 dan beschermt hen de vervloekingseed, die als de donder wordt neergelaten, dan beschut hen de overeenkomst, die als onweersflitsen neerkomt.

62 Puang Matua de Vroegere in het midden van het uitspansel slaat hem steeds gade,

To Kaubanan in het vertrek van het al bedekkende betracht hem voortdurend.

63 Tamborolangi' daalde neer in de wereld, de adatregelingen, die Puang Matua had ingesteld als leeftocht hebbend, Datu Muane zette zich neer op de aarde torsende de volheid van de adatbepalingen.

64 Daarom is het dat de majestueuze opvolger van hem Die glanst als het aanschijn van de Maan, als met horens van neen knikt, wanneer het adatbestel, dat voorspoedig gedijt, op hooghartige wijze als een hoog opstekende horen gehanteerd wordt.

65 Daarom is het, dat de majestueuze opvolger van hem, Die schittert als de Zonnestralen, als met de punten van de horens het hoofd van neen schudt, wanneer de adatbepalingen, die heilrijk zich ontwikkelen, met overmacht worden toegepast, zoals een lans met geitenhaar op en neer geschud wordt. 
66 Rianna Kalindo-bulanan lan Tallu Lembangna ma'lajuk lamba', nasaladan talikuran lan pandan tirindu batu lalikan to dipalo'le barana'.

67 Iamo tang la nakamalingi to ma'duang salu, tang la nakatumangnga-mangngai to ma'kalo' simisaman.

68 Narengnge' mata bubunna keallo kebongi, nasariri tondon turunanna kekulla' kekaroen.

69 Iamo dqtakinan 1a'bo' sangbara' padang, ditekkenan doke sipamula ma'ti ditari'.

70 Dilasakan tanduk, disossokan pasoan bangi', ke denni to ma'minda kumua, ke la dollokki to ma'apa sanganna.

71 Napotedong tunuan batang dikalena to ma'duang salu, naposampin pebalun tondon to batangna to ma'kalo' simisanan.

72 Rianna to Kalindo-bulanan, natang tumambuk ma'duang papa', passaladanna to Kabarre-alloan, natang sumembe' ma'tallu inaa.

73 Tang urria aluk dipakera tambuk, anna tang ussembe' sangka' dipakeko bulituk.

74 Iamo anna siria sumpu marendeng ditanan Kalindo-bulanan, iamo nasisaladan banu' karurungan diranduk Kabarre-alloan.

66 Met Tallu Lembangna: "Het Drietal Landschappen" worden de drie landschappen Sangalla', Ma'kale en Mengkendek aangeduid, die ieder onder het gezag van een puang staan; zij vormen een bijeenbehorend drietal.

Zamba' is een hoge boom met brede, glanzende bladeren, een ficussoort.

68 mata bubun, 1tl. het oog, essentiële van de wel, en tondon tumunan, 1 tl. de rand van zijn put of wel, zijn in zulk een verband de overdrachtelijke uitdrukkingen voor: de toekomstige echtgenote, vgl. de uitdrukking: dikasiri' mata bubunna, dikabangnga tondon turunanna: "hun wel wordt ontzien, voor de rand van hun put neemt men zich in acht"; deze bepaling geldt vrouwen uit de stand der puang en to makaka, die niet met een man van lagere stand mogen huwen. ussaripi: iets aan een band dragen, die over de schouder geslagen wordt, bv. de sirihtas.

70 disossokan, $1 \mathrm{tl}$. wordt voor hem ingewreven met vet of een schuurmiddel. pasoan bangi': de schacht van de lans, die tot verdediging dient, niet om er te slachten dieren mee te steken.

70 De strekking van deze strofe is: wanneer er lieden zijn, die in opstand komen tegen zijn gezag en bevel.

71 Met "de buffel die voor de vrijen en horigen geslacht worden beschouwt hij als de zijne" wordt bedoeld: de buffels, die voor de vrijen en horigen geslacht worden, die gevallen zijn in de strijd tegen de vijand, neemt hij voor zijn verantwoording.

73 tombuk is conjectuur; de tekst had tanduk. 
66 De bescherming van hen Die glanzen als het aanschijn van de Maan in Tallu Lembangna verheft zich als een ficus-boom,

zij beschut op de wijze van een lendejuk in de positie van het vormen van een drietal als de haardstenen, hen, die verheven worden, zodat $z i j$ heen en weer wiegen als een waringin-boom.

67 Daarom zullen de lieden van de stand der vrijen en horigen niet in onzekerheid zijn over hen,

de lieden, die ieder een eigen bevloeiingskanaal hebben niet in verwarring zijn over hen.

$68 \mathrm{Hij}$ heeft dag en nacht de verantwoordelijkheid voor zijn wel, hij moet overdag en wanneer de nacht valt garant zijn voor de rand van zijn put.

69 Het land even oud als zij zijn, is aan hem verbonden, zoals de band met welke het zwaard aangegespt wordt aan de heup, het afgeperkte droge, dat dezelfde aanvang heeft, is één met hem, zoals de schacht met de lans.

$70 \mathrm{Zij}$ worden getroffen door een horen, de schacht van de verdedigingslans is voor hen gereed gemaakt,

wanneer er lieden zijn, die vragen: wie is het, die het zegt, wanneer er lieden met een afwijzend gebaar zeggen: wat is zijn naam!

71 De buffels, die voor de vrijen en horigen geslacht worden, beschouwt hij als de zijne,

het inwikkelen met weefsels van lijken van hen, die ieder een eigen afvloeiingskanaal hebben, neemt hij voor zijn verantwoording.

72 Door de bescherming daarvan is het, dat hij Die glanst als het aanschijn van de Maan niets dubbelzinnigs koestert, door de beschutting daarvan is het, dat hij Die schittert als de Zonnestralen geen leiding geeft in drieërlei gezindheid.

$73 \mathrm{Hij}$ verricht geen regelingen op de adat gebaseerd, waarbij zijn hart bezoedeld zou zijn,

en geeft geen leiding aan adatbepalingen, die bedriegelijk van het rechte worden afgebogen.

74 Dan zal hij, Die glanst als het aanschijn van de Maan, geplant zijn, verbonden met de hoogste maat van zegen, dan zal hij, Die schittert als de Zonnestralen, in de grond gedreven zijn, verbonden met kernharde levensduur. 
$75 \mathrm{Ma}$ 'bulo lollong lako to torro to lino, ma'tallang tang kelesoan lako to unnesung tau mata,

76 natontong ma'lajuk lamba' dipentionganni tananan pemalinna, natu' tuan ma' tarangsu barana' dipellalundunni randukan passalinanna.

77 Iamo naria tannun keallo kebongi sulle gajangna Bulu lan di Ma'kale, sili' sarapangna Palodang lan di Sangalla', sulle gajangna Paetong lan di Mengkendek.

78 Iamo natontongi Puang Matua Ulu dao tangngana langi' keallo kebongi, nanenne'i To Kaubanan lan dasa' to palullungan kekulla' kekaroen.

79 Iamo ditundanan deata ma'tora bassi diong mangapi'na tana, iamo dirujangan puang ma'isi malia diong mangapi'na to kedaenan.

80 Pada ditundan deata patalo tangdo dio randanna langi', pada dirujang puang patongka lemujun dio lelean uran.

81 Situru' lentong saki unnangga', sibarru barana' rammun ma'posanga-sanga.

82 La tongkon titanan tallu Puang Matua lan sangtolinoan, la unnesung tirindu batu lalikan To Kaubanan lan ma'ti ditari'.

83 La umpenunu sanda salunna, la ullingi' kalo' kadaangna.

84 Ianna banu' panganna rara'na, anna kulau' pa'palumpun bulajanna.

85 La napamuntu tang ti'pek rongko', la napamajak tang kalajuan paraja sangsama-sama.

75 ma'bulo lollong: zich gedragen als heel rechte dunne bamboe met lange geledingen; Zollong is de excessieve vorm van lolo: recht. to torro to lino, 1tl. zij die verblijven als, de positie hebben va aardbewoners.

76 ma'tarangsu $=m a^{\prime}$ tarangso $=m a '$ pangso: omhoog stijgen, verheven zijn.

83 kadaang: dijkje langs de afvloeiingskanalen van de sawahs, gevormd van de bij de bewerking opgeworpen aarde; de zin van het beeld is: of al hetgeen geschiedt zijn goede gang heeft.

84 pa'palumpun, $1 \mathrm{tl}$. hetgeen goed bewaard wordt.

85 napamuntu, 1 tl. het doet zijn als hard ijzer, als het gegoten ijzer van een ijzeren braadpan.

napamajak, $1 \mathrm{tl}$. het maakt als de snede van een zwaard, of mes, aan welks ijzer staal is toegevoegd; het grondwoord is bajak: hard ijzer, staal. 
75 Wanneer hij uitermate rechtvaardig is jegens de mensen, wanneer hij zich gedraagt als een bamboe zonder knopen jegens hen, die in de staat van nog levende mensen verkeren,

76 dan zal hij steeds zijn als een hoge ficusboom, bij wie de inzetting van hun verbodsbepalingen gaat schuilen, dan zal hij, steeds omhoog rijzen als een waringin, bij wie de instelling van hun adatinstellingen bescherming zoekt.

77 Die zijn het, die behoed worden als een weefsel bij dag en bij nacht door de majestueuze opvolger van Bullu in Ma'kale, door de doorluchtige opvolger van Palodang in Sangalla', door de majestueuze opvolger van Paetong in Mengkendek.

78 Hem slaat Puang Matua de Vroegere in het midden van het uitspansel steeds gade bij dag en bij nacht, hem houdt To Kaubanan in het vertrek van het al omhullende steeds overdag en bij het vallen van de nacht in het oog.

79 Voor hem wordt gewekt de god met ijzeren hoektanden beneden in de aarde, die in lagen op elkaar ligt, voor hem wordt wakker geschud de geest met rode tanden beneden in de grond, die in lagen op elkaar ligt.

80 Mede wordt gewekt de god, die de vervloekingen in zijn hand heeft, aan de horizon, mede wordt wakker geschud de god die macht heeft over allerlei plagen aan de plaats, waar de regen zich verplaatst.

81 Steeds verergerende ziekten, de een na de ander, die als palen op een rij staan, met kwalen, dicht opeen staande als waringin bomen, die hoe ook behandeld steeds erger worden.

82 Moge Puang Matua in drieën bijeenhorend, gezeteld zijn bij de mensheid, moge To Kaubanan, een drietal vormend als de haardstenen, gezeten zijn op het afgeperkte droge.

83 Om nauwkeurig te letten op al hetgeen passend is, om te aanschouwen de gang van de afvloeiingskanaaltjes tussen de opgeworpen dijkjes.

84 Indien zijn luisterrijke overleveringen duurzaam zijn als kernhout, indien zijn gouden tradities een voorspoedig verloop hebben.

85 Dan zal dat het geluk onbreekbaar krachtig maken, dan zal dat het heel grote heil stevig doen zijn zonder vroegtijdig 
86 Make' 1a sisarakki aluk natanan tallang Puang Matua, anna la simanta mambela sangka' naranduk bulo ala' To Kaubanan,

87 narebong tana' saki makamban tang pangaku-akuan,

la natina' rantang rammun ma'posanga-sanga, tang pangore-orean.

$88 \mathrm{Na}$ make' tang ungkamalingi panganna rara'na Puang Matua Ulu,

ke tang ungkamalingi pa'palumpun bulajanna To Kaubanan,

89 la tontong direngnge' mata buntunna,

la tu'tuan disariri tondon turunanna,

lolong lako matallo matampu' sanda masakke,

90 tianta' tada-tada lako pentutuan lipu sanda kalua' tongkon

maradinding,

umbati' anggenna sakka' saeanna narande tana kalua'.

91 Pada umbati' Kalindo-bulanan,

unnena' mintu' sola nasang,

pada unnena' Kabarre-alloan.

92 Napora' 1indo masakke Puang Matua Ulu, napi 'pik rupa maradinding To Kaubanan, ma'bassi didedek, malalinting tiponi-poni.

86 simanta mambela, 1t1. elkaar uit de verte aandachtig gadeslaan.

89 mata buntunna: het oog, het essentiële, het ware wezen van zijn berg.

90 tianta' tada-tada, 1tl. overal verspreid heen gebracht als stukjes gespleten bamboe, die uitgezet worden op de sawahdijk om te verhinderen, dat men er over heen loopt.

sakka' saeanna, 1tl. al wat gereed is tot het laatste toe van wat er is.

narande tana kalua', 1tl. het wordt op de vlakke hand gedragen doo de wijde aarde. 
86 Evenwel, indien hij zich zou verwijderen van de adatregelingen, die door Puang Matua als bamboe zijn geplant, indien hij zich op een afstand zou houden van de adatbepalingen, door To Kaubanan als dunne bamboe met lange geledingen in de grond gezet,

87 dan zou hij als een staak gebroken worden door zware ziekte, waartegen geen zoenoffers met bekennen van schuld zouden helpen, dan zou hem heel hard treffen een ziekte, die van het ene lichaamsdeel naar het andere zou overgaan en niet zou ophouden.

88 Echter indien hij niet in onzekerheid is over de luisterrijke inzettingen van Puang Matua de Vroegere,

indien hij niet in verwarring is over de gouden verordeningen van To Kaubanan,

89 dan zal de taak, die hij te dragen heeft steeds met verantwoorde$1 \mathrm{ijkheid}$ gedragen worden, de zuiverheid van zijn stand steeds met zorg in acht genomen worden,

hij volmaakt gezegend Oostwaarts en Westwaarts gaan,

90 is er welvaart gevestigd overal heen verspreid over de goed bewoonde plaatsen van het wijde land, vermenigvuldigt zich al wat er is op de wijde aarde.

91 Eveneens heeft hij, Die glanst als het aanschijn van de Maan, kroost, nemen allen in aantal toe, eveneens neemt in aantal toe hij, Die schittert als de Zonnestralen.

92 Moge Puang Matua de Vroegere hem overgieten met een zegenrijk aanschijn, moge To Kaubanan hem besprenkelen met een gunstrijk aangezicht, een lange levensduur hebbend als geslagen $i j z e r$, sonoor van geluid. 


\section{DE TEKSTEN E}

Bij het verrichten van de riten van het maro-feest worden verschillende zangen (gelong) gezongen, in de eerste plaats de grote Maro-zang. Deze is overgeleverd in twee redacties, een langere ( $\mathrm{Ia}$ ), gereciteerd door $\mathrm{Ne}^{\prime}$ Nora', afkomstig uit Sangpolobungin (complex Nonongan), en een daarmee gedeeltelijk parallel lopende aanmerkelijk kortere (Ib), gereciteerd door Sangaju', afkomstig uit Salu (district Kesu'), aan de rechteroever van de Sa'dan-rivier gelegen.

\section{Inleiding bij de eerste tekst ( $E$ Ia)}

Het maro-feest wordt vaak aangeduid met de benaming maro datu of maro sanguzlele. Het heeft de algemene strekking de adatgemeenschap te reinigen van die elementen, die het welzijn kunnen belemmeren, onder welke ziekte wel een voorname plaats inneemt.

Men kan dan, in de cyclus van daarop volgende aan de goden gewijde rituelen, het merok-feest (zie The Merok Feast, p. 1-9) en het bua' kasalle-feest (zie in deze bundel de teksten $\mathrm{H}$ ) gaan vieren.

In The Merok Feast, p. 142-144, B, str. 726-742, wordt gewag gemakt van het eerste maro-ritueel, in het centrum van het uitspanse1 aangericht, vanwege een ziekte van Bannobulaan. Toen werd een bode gezonden naar Indo' Belotumbang (d.i. 'Moeder Sieraad van hen die in bovenaardse toestand verkeren", vgl. hierna p. 39 over to tumbang) in het zenith van het uitspansel, met haar parallelle naam Indo' Bungasampa' (d.i. 'Moeder Bloesem, de Goedwillende") genoemd. In het centrum van het uitspansel genoot zij van een sirihpruim te zamen met de drie hoofdgoden Puang Matua, Puang Bassi-bassian en Puang Ambo-amboan. Het was de wens van Indo' Belotumbang, dat eerst Kambunolangi', de voorvader der priesters zou geroepen worden om de vereiste zoenoffers te brengen. Daarna medicineerde Belotumbang de ziekte met het uitkauwsel van Dracaena terminalis bladeren, vgl. The Merok Feast, p. 145. (De Heer Tammu geeft een wat andere lezing. In de oude tijd was er iemand, die een meisje had, dat geestesgestoord was, Bannobulaan geheten. Op zekeren dag kwam een vriend bij hem op bezoek, die hem ried de hulp in te roepen van Indo' Belotumbang; zij heeft de bijzondere gave in dergelijke gevallen hulp te bieden. Indo' Belotumbang genas het meisje met bloed uit haar eigen lichaam.)

Het Sa'danse woord maro heeft de betekenis van: dol van dieren; 
maro-maro: idioot. Het maro-ritueel heeft dan ook de functie om lieden te behandelen, die geestesgestoord zijn, en heeft zich uitgebreid tot de behandeling van zieken, die op andere wijze niet te genezen zijn. In die functie wordt er een bijzondere band gelegd met Indo' Belotumbang.

Een parallel ritueel is het bugi'-ritueel, dat in de latere jaren veelvuldiger in het Ma'kalese voorkwam, omdat het maro-feest daar door het Ned.-Indisch Bestuur verboden werd wegens de daarin voorkomende situaties van extreme extase.

Voor degenen, die in de Gelong Maro getekend worden als in abnormale toestand te verkeren, worden verschillende termen gebezigd: to malangi', to sala padang, to tumbang, to kandeatan, to kataman, to kasaean, to karondonan.

Het eerste drietal termen is mediaal van karakter en geeft het verkeren in een bepaalde toestand aan. To tumbang is in deze en de overige teksten steeds vertaald met: $z i j$, die in bovenaardse toestand verkeren; to malangi' met: zij, die in vervoering zijn; en to sala padang met: $z i j$, die de grond niet mogen betreden. Er worden steeds mee aangeduid lieden die in bovenaardse toestand verkeren en verbinding hebben met de bovenwereld. Er zijn verschillende episoden in de Gelongs, die hierop wijzen. Het is mogelijk, dat zij dateren uit een oudere cultuurperiode, waartoe ook het bua' kasalle-feest behoort.

Het volgende viertal is passief van vorm. De termen behoren vermoedelijk bij een latere cultuurfase, parallel lopende aan het al genoemde bugi'-ritueel, in welke fase het maro-ritueel het type van trance-verschijnselen kreeg. Dat vindt zijn uitdrukking in de woorden karondonan: op wie een geest is neergevallen, in wie een geest is gevaren, kasaean: in wie de geest gekomen is, kandeatan: door een geest bezeten en tang kantolinoan: in niet menselijke toestand, in abnormaalmenselijke toestand gebracht. Men vergelijke ook de termen katcoman: dol beginnen te worden (van een hond gezegd), ma'pasae: de geest over zich laten komen (waarvan kasean is afgeleid), en de al genoemde uitdrukking: to naala bugi': iemand door een demon in bezit genomen. De latere cultuurstroming heeft de oorspronkelijke zin van de termen tumbang en malangi' omgevormd in die van opspringen en dansende zingen (zie de hierna volgende gelong, str. 46 en 53) en in trance-toestand en in vervoering zijn.

De geest of demon, die in trance brengt, wordt genoemd met de benamingen: bugi': demon, deata: god, puang: heer en to menampa: formeer- 
der, scheppende god.

In deze Gelong Maro, str. 56vv., wordt een beschrijving gegeven van de in trance gebrachte vrouw, die als volgt aanvangt:

'Hij keert haar vorm om,

hij vervormt haar maakse1,

hij doet haar staat tegen de draad ingaan."

Zij heeft een bijzondere geboorte gehad, zoals blijkt uit een andere tekst: De lusten van haar moeder bij de geboorte gingen niet uit naar langsat-, of durian-vruchten, maar naar jonge, nog opgerolde bladeren van de drakenbloed-plant en Dracaena-stengels (bovenwereldse gewassen), een voorteken, dat de vrucht in haar schoot al begeerde op te kunnen stijgen naar het uitspansel.

De door de geest bezetene is steeds aan het zweven en heen en weer vliegen om de andere zijde (dat zal waarschijnlijk de bovenwereld zijn) te bereiken (zie str. 87, 90v.). Zij komt in gebieden, waar de Bonese wind waait, het nu eens helder, dan weer dof klinkend geluid der Hollanders gehoord wordt, de warme luchtstroom van de rand van de hemel langs gaat (vgl. str. 99).

De in trance toestand verkerende ziet dan een menigte prauwen, die telkens omtuimelen (zie str. 107v., 110, 112); zij ziet het uitspanse1 onder zich, de voeten blijven steken in de sterren en zij loopt over de zon heen (vgl. str. 114).

Het gezeten zijn op de prauwen (die beschreven worden in str. 121v.) voert het in trance zijn tot het hoogste punt (vgl. str. 123v.). De in trance verkerende wil dan voortgaan tot Goa en het land der Hollanders en tot de horizon; de rivier die zij ziet loopt tegen de helling op, tegen zijn stroomversnelling in (vgl. str. 138, 142).

Dat het bloed een grote rol speelt bij het in trance zijn komt tot uiting in een aantal strofen, zoals str. 183-185.

In de Gelong Maro wordt verder gesproken over een roodgloeiende berg, een da1, dat een blauw-zwarte rook verspreidt; "dit is zonder twijfel de plaats, waar de heren zich in optocht voor het slotritueel heen begeven (...), de geesten, die uit het Noorden zijn neergedaald (...), heren wier hoofd rood is" (vgl. str. 209v., 213).

Verderop is de in trance gekomene genaderd tot de "Bonese voorgalerij, waar het Hollandse bijvertrek aan bijgebouwd is" (beschreven in str. 242-246). Zij ziet de dingen anders dan normale mensen, zodat haar alles dichtbij lijkt op haar tocht (vgl. str. 251-254), en vertelt hoe "het liefelijke dorp Bone" eruit ziet, dat zij bezoekt en waar zij met goden en heren verkeert (vgl. str. 260v., 266, 268v.). 
Dan volgt haar tocht "langs de zijde van het uitspansel", tot aan "het Noorden, waar de aarde aaneen gelast is" (vgl. str. 277vv., 281v.) langs het pad "dat niet betreden wordt door de aardbewoners", maar waar de goden langs gaan te middernacht (vgl. str. 291, 293v.) .

Daarna heeft de in trance-toestand zijnde de ervaring, dat $z i j$ langs een trap naar het uitspansel gaat en erin doordringt (zie str. 323-325), toegang krijgt tot de verdiepingen van de hemel en de schuilplaats bereikt van wie in bovenaardse toestand verkeert (zie str. 327-333).

En tenslotte vertelt de zang, na nog eens erop gewezen te hebben dat de aardbewoners de dingen niet zien zoals ze werkelijk zijn (vgl. str. 335vv.), hoe de in trance zijnde, "teruggekeerd van het bezichtigen van het uitspanse1", beschrijft wat zij daar gezien heeft: de fraaie grasvlakte in het uitspansel, de daar gebouwde prachtige huizen (vgl. str. 341-344 en 348-351), en de weg waarlangs zij terugreisde (vgl. str. 356v., 359). 
Hae, hae, hae!

1 Mangka kumandemo santung, pura erunmo tulali, maempunmo suling bulo, bassamo sampa bulaan.

2 Sorong-soronganni rangking, annai kandian gallang, sisi' siruk bulaanmi.

3 Tadoimo' belo puduk, sombamo' kapuran pangngan, sola sambako ilole';

4 Angki bangkudu anga'ki, umpi'to landa isingki.

5 Puduk tang sitama berak, tang sielle' lea-lea, tang sola rotean kapu'.

a) De titel van deze zang in een andere overlevering (meegedeeld door Tandilolok, de zoon van Pong Panimba, het voormalig landschapshoofd van Kesu', en door Allorante, voormalig hoofd van de kampung $\mathrm{Ba}$ 'tan in Kesu', beide goede kenners van de adat) luidt: Ossoran gelong diona kamaroan: Overlevering van de zang betreffende het maroritueel. De tekst van de zang, die ik van hen ontving, is voor ongeveer de helft verloren gegaan. Waar het overblijvende gedeelte varianten vertoont ten opzichte van tekst $\mathrm{E} I \mathrm{Ia}$, worden die in de noten vermeld. - Als inleiding heeft de variant vobr str. 1: Ia parrulanna dikua: Het begin er van, luidende; dikua, 1tl. er wordt gezegd.

1 santung: "tokkelinstrument" wordt hier overdrachtelijk gebezigd voor de lieden, die de maro-zang zingen. Dit zelfde geldt van de fluiten van dunne gele bamboe in het derde lid van de strofe. bassa'mo sampa bulaan; de vertaling van deze woorden is niet duidelijk. Mijn informant J. Tammu citeert uit de gelong maro $\mathrm{E}$ Ib: sarinni bota bulaan: veeg de gouden korrels weg. Naar analogie daarvan stelt hij als vertaling van bassa'mo sampa bulaan voor: men is al bezig geweest de heilige resten (van de maaltijd der goden) weg te vegen; bulaan (goud) betekent in de dichterlijke taal: heilig. 
He, he, he!

1 Reeds hebben de zangers gegeten, de tonen van de tweelingfluiten zijn zwakker geworden, de fluiten van dunne gele bamboe zijn gereed, men is al bezig geweest de heilige resten weg te vegen.

2 Reik het mandje aan, berg de etensschaal van messing op, steek uw gouden lepel op zijn plaats.

3 Reik mij het versiersel der lippen aan, geef mij in de holle hand het bestrooien met kalk van de sirihpinang, en opgerolde tabak.

4 Opdat onze monden rood worden, de welving onzer tanden rakende.

5 De lippen, die niet behoorlijk zijn voor het rode speeksel, die niet betamelijk zijn voor het rode, die niet in harmonie zijn met het schudden van de kalk.

2 rangking: wijd gevlochten mandjes van de bladnerven van de suikerpalm; men legt er de sirih-pinang in bij de offers aan de goden.

3 "het versiersel der lippen" is de sirihpruim, die de lippen rood kleurt. iZole', poëtisch voor: dizole': "is opgerold"; variant: Zole'.

4 Angki bangkudu anga'ki, 1 tl. opdat onze monden als Indische meekrap worden; bangkudu, Indon. mengkudu: de Indische meekrapboom, Morinda tinctoria, die rode kleurstof oplevert.

5 De woorden van deze strofe hebben volgens de heer Tammu eigenlijk betrekking op de to ma'dompi, de medicijnmeester, of in nog origineler verband op Indo' Belotumbang, die in de bovenwereld in de oertijd voor het eerst ziekte is gaan behandelen, zie Inleiding op deze zang, p. 38. Voordat men de gelong gaat zingen, krijgt de to $m a^{\prime}$ domp $i$, de leider van het ritueel, een maaltijd aangeboden. Daarna bezigt hij de woorden van deze strofe, alsof hij in kwasi bescheidenheid iemand is, wiens lippen geen sirih-pruim waardig zijn. De bedoeling is, dat hem de betel ingrediënten zullen worden aangeboden. 
6 Puduk pampana puang, panggaraganna deata, pangligi' misa-misanna.

7 Da mimalle maling, puang, da mileaga, deata, da mili'pang, to manampa.

8 Alukna banne to tumbang, patarukan to malangi', amboran to sala padang, gau' to kandeatan.

9 Ke den to narampa bugi', nasinakan sanggaria, naalakan to lumuran, bongsu to ma'palo-palo.

10 Sangbara', sangturanan 1e! tungka sangrumbo dadie!

11 Tang madandengkoka iko, tang dallo-dalloangkoka, tae'ka timpaiomu?

12 Deata ia marandeng, puang ia ma'udadi, silele ma'rio-rio.

13 Ikoka tang la madandeng, silele tang ma'udadi, tunduk tang ma'rio-rio?

6 pangligi', 1t1. vlokken kapok tot grote ballen ineengedraaid.

7 to manampa. De variant luidt: to menompan, met dezelfde betekenis.

9 bugi' is de naam van een ritueel, zie Inleiding, p. 39; vgl. bugi': boze geest, demon; untammi bugi': de boze geest tegemoet gaan; bugiran: door de demon bezeten zijn. - Bugi' ${ }^{\prime}$ in deze gelong gebezigd, wijst op de relatie tussen het maro- en het bugi'-ritueel. sanggaria: titel van iemand, die gezag uitoefent, bestuurder; titel o.a. van het hoofd van het landschap Badjo' in het Palopose; het heeft in dit verband, evenals dat het geval is met de woorden datu: "vorst", puang: "heer", de betekenis van: geest, godheid. "degene, die met mos bedekt is" heeft de betekenis van: de heel oude. palo-paZo: een hoofddeksel door Buginese mannen gedragen; ook voorname Toradja-mannen zijn er wel mee getooid. 
6 De lippen door de heren geschapen, het maaksel van de goden, het uniek gevormde.

7 Weest niet verbijstert en verward, heren, weest niet uw zinnen kwijt, goden, weest niet ontzet, scheppers.

8 Het ritueel van het kroost van hen, die in bovenaardse toestand verkeren, de afstammelingen van hen, die in vervoering zijn, de nakomelingen van hen, die de grond niet mogen betreden, de handelwijze van hen, die door een geest bezeten worden.

9 Wanneer er iemand is, die door de demon bezeten wordt, wij door de geest begeerd worden, degene, die met mos bedekt is, ons haalt, een nakomeling van iemand, die een stijf gevlochten hoed van

bamboe draagt.

10 Een leeftijdgenoot, een gelijkgeborene, die echt te zamen met de ander voorspoedig geboren werd.

11 Zijt gij, gij dan niet ontroerd, hebt gij dan geen medegevoel, heeft $\mathrm{u}$ geen weemoed bevangen?

12 De geesten zij zijn ontroerd, de heren $z i j$ branden van verlangen, overal zijn zij weemoedig gestemd.

13 Zult gij niet ontroerd zijn, zult gij niet overal branden van verlangen, en $\mathrm{u}$ neigend mede weemoed betuigen?

10 De variant heeft in regel a: pada dipangidenalle = dipangidenan le: "een voor wie de moeder op dezelfde tijd de lusten kreeg". - In sangturanan $l_{e}$ en in dipangidenan le treft men het element $l_{e}$ aan, dat als stopwoord om het metrum vol te maken toegevoegd is. De $e$ van dadie doet voor hetzelfde doel dienst.

11 De variant heeft: marandengkoka; de $d$ en de $r$ wisselen vaak af in het Sa'dan-Toradjaas. In 12 hebben beide teksten marandeng, maar in 13 heeft $\mathrm{E}$ Ia weer madandeng. 
14 Untiro banne to tumbang, patarukan to malangi', amboran to sala padang, gau' to kandeatan.

15 Ma'parra-parra onimo', rampi'-rampi' gamaramo', tibonto' lengko lilamo'.

16 Deata sambalin Ara', puang randan Bone-Bone.

17 Balombongko dua buntu, rubakko tallu tanete.

18 So 'boammo' gamarangku, rubakki lengko lilaku, angku ma'gamara pindan, angku messa'da bombongan, angku ru'sen giring-giring.

19 Tenmo' giring-giring ko'ka', sariajan dibukai, bangkula' dipangandaran, gallang didende-dendean.

20 Nadende-dendean pande, nasauran to manarang nakangkan rangga inaa pande tipasengo-sengo.

21 Tang didedek anna roreng, anna rumangga oninna, anna tipasengo-sengo.

15 ma'parra-parra onimo' is een kwalificatieve samenstelling, waarbij het subjectssuffix achter het tweede lid staat. Ditzelfde is het geval met de samenstelling rompi'-rampi' gamaramo', $1 \mathrm{tl}$. ik ben reeds overgeslagen van stem, en in tibonto' lengko lilamo', 1tl. ik ben al blijven stokken in de geregelde kronkeling van de tong.

16 sambalin is ontstaan uit sambalinna en dat bestaat uit het woord sambali (vgl. sangbali: de ene zijde van een paar) en het possessieve suffix $-n a$. De naam Bone zal vanwege het metrum herhaald zijn. Bone duidt hier het rijk Bone aan. 
$14 \mathrm{Bij}$ het zien van het kroost van hen, die in bovenaardse toestand verkeren, de afstammelingen van hen, die in vervoering zijn, de nakomelingen van hen, die de grond niet mogen betreden, de verrichtingen van hen, die door een geest bezeten worden.

15 Ik heb reeds al mijn geluid eruit geperst, mijn stem is al overgeslagen, ik ben al blijven steken in de geregelde loop van mijn woorden.

16 De goden aan de overzijde in Arabië, de heren aan de rand van Bone.

17 Breek een holle weg open tussen twee bergen, maak een opening tussen drie heuvels.

18 Breek mij mijn stem open, maak een opening in het gewelfde van mijn tong, dat ik een stem hebbe als een porseleinen bord, dat mijn stem doorklinke als een gong, dat ik steeds klinke als het geluid van een bel.

19 Dan ben ik als een rinkelende bel, als een klein rond belletje, dat heen en weer schudt, als een koperen bel, waarmee men de manganda'-dans uitvoert, als een koperen voetring, die heen en weer geschud wordt.

20 ze wordt door de kundigen heen en weer geschud, ze wordt door de bekwamen heen en weer bewogen, ze wordt op de hand gehouden door hen, die rijk zijn aan gedachten, $z e$ is vaardig een steeds klinkend geluid te geven.

$21 \mathrm{ze}$ wordt niet geslagen en geeft toch voortdurend geluid, ze heeft verscheidenheid van tonen, ze heeft een steeds doorklinkend geluid.

17 Met "de twee bergen" worden hier de rijen der tanden en de beide lippen bedoeld en met "de drie heuvels" de keel, de tanden en de lippen.

$18 \mathrm{ru}^{\prime}$ sen heeft de eigenlijke betekenis van "bedrukt/bezorgd" en van daaruit die van: het steeds maar hebben over iets, waarover men bezorgd is; algemener: iets voortdurend doen, hier: steeds klinken.

20 De variant luidt in regel c: nabantan rangga inaa: ze wordt op de schoot gehouden door hen, die rijk zijn aan geest. 
22 Susi santung rua ka'bi', tulali tang sala' temme', riti tang pinda oninna, tang tibonto' gamaranna, tang leluk lengko lilana.

23 Ke natandere pindanni, ke narande banajai, ke nasajo-sajoanni, ke napa'petiroanni, inde te rante kalua', dipaladan sea-sea, ditandung ma'rio-rio.

24 Mamma' allora' to ina', natuli tingkaru'du'ku.

25 Napamamma' salle manik, napakalupi-lupian, dambara'-dambara' mamma', dambara' natuli tindo, Indo' tang mutundan mamma', tang mupatingkajang mamma'!

26 Anna lendu' puang banga', datu untangko kalena, deata kalle-kallean.

27 Pantan ula-ula tabang, pantan salampe lassigi', pantan bobong bura pi'to. 28 Ungka1lo-kallona' mamma', usseangla'na' matindo, untundanna' kalupian.

22 santung ma $k a^{\prime} b i$ ', $1 t 1$. een tokkelinstrument, dat bij het aanslaan goed getroffen wordt. tulali tang sala' temme', 1t1. een fluit met twee pijpen, die op de juiste wijze wordt aangedreven.

23 banaja = banaa: uitgehold stuk hout, waarin men ontbolsterde rijst, een ei en drie gele kralen doet en dat op het la'pa' kasalle-feest in de nabijheid van de anak dara wordt neergezet; in de maro-zang: grote kom van aardewerk met korte voet. Zie ook str. $277+$ noot. ma'rio-rio, 1t1. treurig stemmen, bv. van een geluid of van een uitgestrekte, eenzame vlakte. 
22 Als een tokkelinstrument, waarvan de snaar zuiver aangeslagen wordt, een fluit met twee pijpen, die op de juiste wijze wordt bespeeld, het koperdraad, welks geluid niet verandert, welks stem niet stokt, welks geregeld doorlopende klank zich niet wijzigt.

23 Wanneer men het als een bord op de handpalm houdt, wanneer men het als een aarden kom op de vlakke hand draagt, wanneer men het heen en weer doet zwaaien, wanneer men het demonstreert, hier op het ruime veld, op het zeer uitgestrekte erf, op de eenzame vlakte.

24 Ik sliep overdag zoëven, mijn slaperigheid nam mij mee.

25 De edele vrouwe bracht mij in slaap, zij deed mij vast slapen, ik heb heus echt geslapen, de slaap nam mij echt mee, Moeder, $u$ hebt mij maar niet gewekt, ge deed mij niet opschrikken uit de slaap!

26 En toen is de nieuwe heer voorbij gekomen, de geest, die zich in een bijzondere gestalte vertoont, de verwondering opwekkende god.

27 Iedere pluim van Dracaena-bladeren, iedere over de borst geslagen sjaal van drakenbloed bladeren, ieder hoofdversiersel van het schuim van de danga-danga-bloem.

28 Als maar tegen mij aan wapperend storen $z i j \mathrm{mij}$ in de slaap, zij maken mij onrustig en houden mij uit de slaap, zij maken mij wakker uit de diepe slaap.

25 salle manik, 1t1. die veel kralen heeft; dit is de honorifieke benaming van een vrouw van edelen bloede.

De variant luidt in regel b: napakalupi allonan: het hoofdkussen deed mij vast slapen.

26 puang banga': "de nieuwe heer"; puang betekent hier, evenals datu in de volgende regel: geest, godheid en is de parallel van deata.

27 lassigi', een poëtisch woord als parallel naast tabang gebruikt: Dracaena terminalis. 
29 Ke tangnga-tangnga bongi, ke sisamanni malillin, ke kapeden-pedenanna.

30 Tipatumbanna te bongi, tiapanna te malillin, te dao to palullungan.

31 Randuk ma'tangngai bongi, la sisamanni malillin, la kapeden-pedenanna.

32 Angki kendek tumundenni, rumujang tangnga bongi, umpemangka kumandei.

33 Rumundu' kadanna puang, pau-paunna deata, sun pudukna to menampa.

34 Tang dirundu'oi puang, tang dipeolaioi!

35 Mataku'ki' la nasangngang, lallenki' la nabutai, la napada'dua linggi', la napa'tallu pangloli, la naimpa' lua' toding.

36 Dadi tenmi to a'ganna, dikale pasiruanna, ke'de' tang umba-umbana.

37 Tang amba-ambana linggi', tang pessojanna pangloli, tang tendengna lua' toding.

38 Maamba-amba to Bone, mapangkaran to Balanda, matendeng to Tana tangnga.

$39 \mathrm{Ka}$ 'nanna narampa bugi', nasinakan sanggaria, naalakan to lumuran, bongsu to ma'palo-palo.

29 Deze strofe ontbreekt in de variant.

35 pangloli, 1 tl. zwarte buffel, wiens staart een wit uiteinde heeft; Iua' toding, 1t1. die een grote stip heeft op het voorhoofd. 
29 Te middernacht, halverwege het duister, toen het doodstil was.

30 wat is er aan de hand deze nacht, wat gebeurt er in deze duistere stonde, hier boven in dit uitspansel, dat het al omhult?

31 Het begon het midden van de nacht te worden, het zou halverwege het duister worden, het zou de tijd zijn van doodse stilte.

32 Toen was het, dat wij naar boven gingen om te wekken, om te middernacht wakker te schudden, en te wachten, totdat hij klaar zou zijn met eten.

33 Volgende het woord van de heer, het door de god gesprokene, hetgeen van de lippen kwam van de schepper.

34 Zou de heer niet gevolgd worden, zou er niet in zijn spoor gegaan worden:

35 Dan zouden wij vrezen, dat hij verderf over ons zou brengen, zouden zij bang zijn, dat hij ons blind zou maken, dat de aanzienlijke ons in tweeën zou delen, dat de voorname ons in drieën zou delen, dat de edele heer ons zou splijten.

36 Zo dan is zijn wijze van doen, bij het wezen van zijn handelwijze, hij vertrekt maar niet ergens heen.

37 Het is niet de krachtige gang van de aanzienlijke, het is niet het zwaaien met de armen van de voorname, het is niet hetgeen geprezen wordt van de edele heer.

38 De Bonieren hebben een krachtige gang, de Hollanders zien er fors uit, de lieden van het Middelland worden geprezen.

39 Sedert wij door de demon bezeten zijn, wij door de geest begeerd worden, degene, die met mos bedekt is, ons haalt, een nakomeling van iemand die een stijf gevlochten hoed van bamboe draagt. 
40 Mara'na tonna to 1 ino, tonna tongkon tau mata, tonna rimantana-tana,

41 bua'mata tang nabela, pentiro tang naarroi, kada tang napau-pau.

42 Apapi pole' totemo, to bulan tatingajoi, allo dirande te langngan?

43 Ballo baruramo' pale', simbolong mapeangla'mo, lokkon pasomboanomo'.

44 Dadi angin-anginomo', kombong talimpuru'omo, talimpuru nadoloi, angin natonda lumingka.

45 Nadoloi anna tumbang, natonda anna malangi', anna runtuk sala padang, anna lao kandeatan.

46 Mata'ka'mo' lao tumbang, bojo'mo' lao malangi'.

47 Tenmo' to nalango bua, to namammanni baolu, to nalumpe' bua tasak.

48 Morong tang nalango bua, tang namammanni baolu, tang nalumpe' bua tasak.

49 Tenmo' ula-ula kura', bandangan tang liu-liu, bembe tang lako eali.

42 "in de dagen, die wij opwaarts op de vlakke hand houden" heeft de betekenis van: in de loop van deze tijd.

43 barura, $1 t 1$. een scheiding in het haar; in d.t. een benaming van een voorname vrouw; vgl. ook de noot bij C, str. 14. In overeenkomstige betekenis worden gebruikt simbolong en Zokkon, 1t1. haardracht, waarbij de wrong dwars gevouwen wordt en in twee gelijke helften verdeeld; bij de simbolong geschiedt dit met een strengetje haar, bij de Zokkon met een bandje. 
40 Helaas, toen hij een mens was, toen hij verblijf hield als een aardbewoner, toen hij vertoefde op de aarde,

41 kon hij de ogen niet openen, hief hij de blik niet op, woorden sprak hij niet.

42 Wat zal er dan nu weer heden zijn, in deze maand, die wij vóór ons hebben, in de dagen, die wij opwaarts op de vlakke hand houden?

43 Ik ben een schoonheid, een dame, die voortdurend om iets vraagt, een vrouwe, die de anderen overtreft.

$44 \mathrm{Ik}$ ben dan nu wind geworden, ik ben dan nu gevormd tot wervelwind, de wervelwind stevent zij voorbij, de wind vliegt zij in haar loop voorbij.

$45 \mathrm{Zij}$ vliegt die voorbij en komt in bovenaardse toestand, $z i j$ stevent die voorbij en raakt in vervoering, zodat $z i j$ het de grond niet mogen betreden najaagt, en door een geest bezeten voortgaat.

46 Ik ben vermoeid bij het voortgaan in bovenaardse toestand, ik ben afgemat bij het in vervoering zijn.

$47 \mathrm{Ik}$ ben als een die bedwelmd is door arecanoten, een, die verdoofd is door betel, een, die verslapt is door rijpe vruchten.

$48 \mathrm{Als}$ het eens was, dat zij niet bedwelmd is door arecanoten, dat $z i j$ niet verdoofd is door betel, dat $z i j$ niet verslapt is door rijpe vruchten.

49 Ik ben als een trotse pluim, een onovertroffen statielans, een stok met geitehaar versierd, die niet lostrekt op de vijand.

44 De woorden van deze strofe worden gesproken door de to tumbang of door anderen, die in trance zijn gedurende het maro-ritueel, een man of een vrouw, mannen of vrouwen. - Het prefix voor het persoonlijk voornaamwoord derde persoon bij vervoegde vormen (na-) en het suffix voor het corresponderende bezittelijk voornaamwoord $(-n a)$ is neutraal t.a.v. getal en geslacht. Ik vertaal in str. $44 \mathrm{v}$. "zij vliegt" etc., maar de werkwoordsvormen zouden ook met "hij vliegt" of "zij vliegen" etc. vertaald kunnen worden.

49 bandangan: geitehaar aan een bamboestok bevestigd; het zal hier wel gebruikt zijn in de betekenis van: doke bandangan: lans aan beide zijden aan het uiteinde met geitehaar versierd. 
50 Napobua' lalong puang, napaten $1 a^{\prime}$ te deata.

51 Megaraga sanda'-sanda', metampa tang lunga-lunga.

52 Sanda'-sanda'mo' sangtinting, sanda'mo' sangpemanikan, sanda' sangtikuan kollong.

53 Napobua' katumbangan, napaten kamalangiran, kamaladende-dendean.

54 Tang ditirorika lako, tang ta'parika matanta, tae'ka pessaileta?

55 To natampa pole' puang, to naburinda deata, naligi' to palullungan.

56 Nabaliangan tampana, nabibiran garaganna, nasule pasiruanna.

57 Nabaliangan napessak, nabibi' nakau pindan, naru'puk kandian gallang.

58 Tibaliang pangallomo, tibibi' pa'balantanmo, sanggang pa'bangkuduammo.

$50 \mathrm{Als}$ regel $\mathrm{c}$ heeft de variant hier: te dao to paluzlungan: dit hier boven, dat het al omhult. $\mathrm{Na}$ str. 50 heeft de variant nog de strofe: Buajanna inde puang, bendo'o inde deata: Verschrikkelijk deze heer, geweldig deze god. Buaja: krokodil, bendo': mysterieus riviermonster; buaja bendo': uitroep van schrik of boosheid: verschrikkelijk, drommels nog toe.

51 Zunga-lunga: ruim voldoende, vrij veel.

55 naburinda, 1t1. hij heeft haar geslepen op een draaiende slijpsteen.

naligi', 1t1. hij heeft haar ineengedraaid.

58 tibaliang, vgl. de term balian van de Ngadju-Dajak, door Adriani verklaard als: vervormd, wat te vergelijken is met halian bij de To Seko, zie J. Kruyt, (1920), 235. pa'bangkuduan: schaal in welke kleurstof is, uit de bast van de bangkudu-boom, Morinda tinctoria, gewonnen. 
$50 \mathrm{Zij}$ wordt bewerkt door de hevigheid van de heer, het wordt met haar zo gedaan door de bliksem van de geest.

51 Ons formerende in onvolmaakte staat, ons scheppende op gebrekkige wijze.

52 Ik ben geheel onvoldoende als een enkel snoer, onvoltallig als én enkele kralenketting, onvoltallig als én enkele halsomspanning.

53 Het wordt veroorzaakt door het in bovenaardse toestand zijn, het wordt zo bewerkt door het in vervoering zijn, het zich op en neer wiegen.

54 Hebben wij er geen gezicht op, valt ons oog er niet op, kijken wij er niet naar om?

55 Haar, die toch door de heer geschapen is, die door de geest geformeerd is, die door het al omhullende gevormd is.

$56 \mathrm{Hij}$ keert haar vorm om, hij vervormt haar maaksel, hij doet haar staat tegen de draad ingaan.

$57 \mathrm{Hij}$ keert haar om en verbrijzelt haar, hij vervormt haar en stoot er tegen als tegen een stenen bord, hij deukt haar als een koperen etensschaal.

58 Omgekeerd is zij als hetgeen gedroogd wordt, vervormd is ze als de plaats, waar uit elkaar gehaalde rijstbossen gelegd worden,

$z i j$ is stuk gegaan als een schaal, waarin kleding, die met mengkudu-kleurstof rood gemaakt is, gedompeld wordt. 
59 Tengo pangallo bokoran, pa'balantan nauranni, pa'ro'pek natalo lemo, pi'to nalonta uai.

60 Masaimo napeangla', ra'damo napebarinni, napeangla' ten beluak, naunu' ten lawa-lawa.

61 Kellolo punti lebani', ten panakan diajunni, ten lambung natuli bara', pi'to nalonta uai.

62 Unu' barinni'na puang, pa'pebarisi-risinna, pamuso' tang kebobongna.

63 Buaja kulambi' lenni, bendo' kutambai lenni, kuangloa-1oa lenni.

64 Kusangai tuak tanning, ta'bu ilampa-lampai.

65 Tuak essun ia maro, bumbungan sangbongi ia, barra' dirammei ia.

59 bokoran: hetgeen, waaraan men de rug toekeert.

Regel c, "een voorwerp, dat lang aan de werking van citroensap is blootgesteld geweest en week geworden is" geldt voorwerpen van staal, bv. een zwaard, kunstsporen voor vechthanen; de bedoeling is, dat zulk een stuk goed daardoor slap en onstevig wordt.

60 nopebarinni, deze vorm wordt in het Wb. verklaard als een verlengde, dichterlijke vorm van napebari, een afleiding van +bari, waarvan de vorm nakabarii in gebruik is, betekenende: hevig verlangen naar.

De bedoeling van regel $c$ is, dat $z i j$ er zonder ophouden naar verlangt, als hoofdhaar, dat voortdurend groeit.

Regel d heeft de betekenis: zij spint aan haar verlangen, zoals een spin steeds verder spint aan haar web.

61 De punti lebani'-soort is ons niet bekend. De Zambung-boom levert goed timmerhout.

64 ilampa-Lampai is een dichterlijke vorm voor: dilampa-Zampai: het wordt lang in een bamboe-geleding gekookt.

65 Deze drie regels geven te kennen, dat men met het ondergaan van het maro-ritueel veel te doorstaan heeft. 
$59 \mathrm{Zij}$ is als hetgeen gedroogd wordt, waar niet meer naar omgekeken wordt,

als de plaats waar uit elkaar gehaalde rijstbossen gelegd worden en waar de regen op neervalt,

een voorwerp, dat lang aan de werking van citroensap is bloot-

gesteld geweest en week geworden is,

een stuk goed, dat lang in kleurstof gedompeld is geweest om het te verven.

60 Reeds lang verlangt zij er naar,

reeds geruime tijd smacht $z i j$ er naar;

zij verlangt steeds ernaar, zoals dat het geval is met hoofdhaar, zij spint er aan, als een spin.

$61 \mathrm{Zij}$ spruit uit als een Zebani'-pisangsoort, als een panakan-slang, die heen en weer gezwaaid wordt, als een lambung-boom, waar de wind tegen aanstormt, een stuk goed, dat lang in kleurstof gedompeld is geweest om het te verven.

62 Het fijne spinsel van de heer, zijn spinsel op het allerfijnst gesponnen, de van de pitten ontdane kapok zonder iets hards er in van hem.

63 De verschrikkelijke, steeds bereik ik hem, de ontzettende, steeds roep ik tot hem, steeds schrei ik om hem.

64 Ik meende, dat het zoete palmwijn was, suikerriet lang in een bamboegeleding gekookt.

65 Zure palmwijn is het maro-feest, melk, die een nacht gestaan heeft, ontbolsterde rijst, in water geweekt. 
66 Indo' le to kumombong e!

tau to mendadian $e$ !

to meparede rara'i,

to mekombong bulajanni, meligi' ponto lola' e.

67 La mekutanapa' mati',

la meosik paramepa',

la metandasa-dasana'.

68 Tumbara bulan dadingku, lillinan pangidenangku?

69 Kombong loera'ka inde, dadi allo salara'ka?

70 Angku isonda ke uran, diala ke kanasuan, sola kataman tedong.

71 Pangidenanna indo'na, dikaelo'-eloranni, tampak pekapaoanna.

72 Mangidenni lolo tabang, kombongi tangke lassigi', dikurapak danga-danga, dialla' bangkudu api.

73 Tang membuarika langsa', tang tarri'rika durian, tang 1ako-lakoandika?

74 Anna tang kandei sindo', anna tang onta-ontai, anna tang pepurairi?

75 Lolo tabang naporai, lassigi' nakaelo'i, pi'to nakasuallai.

66 Aan to kumombong e!, to mendadian e!, Zola' $e$ ! is een $e$ toegevoegd om de maat van de regel vol te maken. ponto $20 a^{\prime}, 1 \mathrm{tl}$. een armband bestaande uit een ring als middelpunt, waar omheen gouden staafjes zijn gestoken, op welke edelstenen zijn gezet. 
66 Ach moeder, degene, die in het aanzijn heeft geroepen, degene, die gebaard heeft, degene, die op luisterrijke wijze deed ontstaan, $z i j$, die ons op gouden wijze in het aanzijn riep, ons formerend op illustere wijze.

67 Laat ik aan $u$ de vraag stellen, laat ik op rustige wijze nog vragen, laat ik om voldoende opheldering mogen verzoeken.

68 In welke maand was mijn geboorte, de nacht in welke het hebben van de lusten zich voor mij voordeed?

69 Ben ik hier in zwakheid ontstaan, ben ik op een ongeluksdag geboren?

70 Dat ik werd opgevangen, toen het regende, genomen werd, toen het tijd was om te koken, en dat de buffels de stal ingingen?

71 De tijd van de lusten van haar moeder, hetgeen door haar verlangd werd, het einde van haar begeren van mangga-vruchten.

72 Haar lusten gingen uit naar jonge, nog opgerolde bladeren van de drakenbloedplant, toen $z i j$ zich vormde in haar baarmoeder waren het Dracaenastengels, in de vertakking van de kembang sepatu, in wat zich bevindt tussen de zeer rode Morinda-takken.

73 Droegen de langsat-bomen geen vrucht, hingen de durian-bomen niet vol vruchten, waren die in het geheel niet te bereiken?

74 Dat de edele moeder ze niet at, dat zij ze niet met gulzigheid verslond, dat $z i j$ ze niet tot het laatste toe opmaakte?

75 Jonge nog opgerolde bladeren van de drakenbloedplant verlangde $z i j$, Dracaenabladeren begeerde $z i j$, met hetgeen waarin kleren gedompeld worden om ze te verven ging $z i j$ kwistig om.

72 de drakenbloedplant (Dracaena terminalis) is de uit het uitspansel neergehaalde plant, op welker bladeren de offers bij het maroritueel gelegd worden. 
76 Lolo tabang diarru'na, lassigi' dipeangla'na, pi'to dilinde-lindena.

77 Disanga leko'na puang, pasuleanna deata, to aluk misa-misanna, garaga tang dilambi'na, tampa tang ditongainna.

78 La ditulakraka langi', la dimanangngairaka, la dirande pala'raka?

79 Tang ditulak ia langi', tang dimanangngai ia, tang dirande pala' ia.

80 Umpatumbang panampana, malangi' panggaraganna, pangligi' misa-misanna.

81 Parannu-rannu indo'na, sende to mendadianna, nakua ditampa linggi', dikombong misa pangloli.

82 La mentia'-tia' manna, la sumalimbajo manna, la ta'pa sambalin manna.

83 Susi pentia'na ipo, sumajangna longa langi', ta'panna doke deata.

84 Sangdoke-doke iangle', sangtinaran maeloi, sangkumba' roto api e.

$85 \mathrm{Tae}^{\prime}$ tiramban kuissan, tae' $1 \mathrm{i}$ 'pang leagana', angku susi to iungka', to iaung sala-sala.

80 Degenen die deze handeling verrichten zijn de goden.

83 De Heer Tammu meent, dat de overhellende luifel van het uitspansel een parallel is van de in de volgende regel genoemde doke deata: de lans der goden, waarmee het weerlicht wordt aangeduid.

84 Volgens de Heer Tammu is iangle' = iangla'. roto api: vurige pijltjes van een blaasroer. 
76 Afgeschrapte jonge, nog opgerolde bladeren van de drakenbloedplant, Dracaenabladeren daar was $z i j$ bezorgd om, hetgeen waarin kleren gedompeld worden om ze te verven, dat werd nauwkeurig beschouwd.

77 Het wordt het bijzondere van de heer geacht, het averechtse van de god, zijn eigen ceremonieën, een onbereikbare gestalte, een vorm, waar niet van uit de hoogte op neergekeken wordt.

78 Zou het uitspansel gestut worden, zou het door stijlen geschraagd worden, zoals in het midden van de wand van een huis, zou het op de vlakke hand gedragen worden?

79 Het uitspansel wordt niet gestut, het wordt niet door stijlen geschraagd, zoals in het midden van de wand van een huis, het wordt niet op de vlakke hand gedragen.

$80 \mathrm{zij}$ brengen hen, die door hen geschapen $z i j n$, in bovenaardse toestand, zij die door hen geformeerd zijn, zijn in vervoering, zij die op bijzondere wijze gevormd zijn.

81 Steeds verheugd is haar moeder, blijde is $z i j$, die haar gebaard heeft, zij zegt: $\mathrm{Zij}$ is als een aanzienlijke geschapen, $z i j$ is als een voorname geformeerd.

$82 \mathrm{Zij}$ is maar aan het heen en weer vliegen, $z i j$ is maar aan het zweven, zij zal zich slechts aan de overzijde neerzetten.

83 Als het vliegen van de giftige pij1tjes, het zweven van de overhellende luifel van het uitspansel, het zich neerzetten van de lans der goden.

84 Een bundel lansen, die geregeld gebruikt wordt, een bundel mooie pijltjes, de proppen van vurige pijltjes, die overal heen schieten.

$85 \mathrm{Ik}$ ken het verschrikt zijn niet, ik ben niet beduusd noch beteuterd, dat ik zou zijn, als iemand, die opgejaagd wordt, iemand, die voor de schijn belaagd wordt. 
86 To nabalomboi doke, to nabombonni pangarru', narauk api deata.

87 To ke ilannamo' leu, to ke lendu' tamaomo', rengke'mo seseanomo'.

88 Umpatandek-tandek sudi dipaladan tian tingke', digirik susi unuran.

89 Susi unuranna datu, bali tingke'na karaeng, girikanna tau la'bi', sudi to tang gana-gana.

90 Tenmo', to undudung langi', to nao' tonno batara,

91 Nasa'pekki tangke kila' narauk api deata.

92 Tibuang-buang darra'mo', tipasirri' sarambumo', timbobong landa-landamo'.

93 Landa-landa tonta pia, timbobong tonta baitti', tonta idende-dendean.

94 Nadende-dendean pande, nasauran to manarang, nakangkan rangga inaja, pande tipasengo-sengo.

95 Rumende-mende ara'ku, bali allun penaangku, rumintik pa'kaleangku, sudu lamba' beluakku.

96 Urrangi re'dena tasik, kumala'dakna uai, umbo' tokna bura-bura, somba'na' bete lumuran.

86 nabalomboi staat hier voor nabalombonni: op wie veel stenen of aarde of andere dingen geworpen worden. pangarm', 1tl. hetgeen afgeschrapt is, d.i. een pijltje van het blaasroer.

88 tian schijnt een oudere vorm te zijn van het gebruikelijke ten: zoals, als ware het. 
86 Iemand, op wie veel speren geworpen worden, die overdekt is met pijltjes, gestoken door het vuur der goden.

87 Wanneer ik daarginds zou zijn, wanneer ik er verder in zou gekomen zijn, dan zou ik dicht bij de andere zijde zijn.

88 De klos om het garen op te winden zwaaiende op de voorgalerij als ware het een spinrokken, gedraaid als een spinnewiel.

$89 \mathrm{Als}$ het spinnewiel van de god, als het spinrokken van de heer, het ronddraaien door de verhevene, het toetsen door de hogere machten.

$90 \mathrm{Ik}$ ben als een die het uitspansel op het hoofd draagt, een op wie de hemel drukt.

91 Die de vertakking van de bliksem afrukt, door het vuur der goden gestoken wordt.

92 Ik ben neergeworpen als een stroomversnelling, ik ben weggestoven als een waterval, ik spring op als een sterke stroom.

93 Een sterke stroom, toen wij kinderen waren, opspringend, toen wij klein waren, toen wij van boven naar beneden geschud werden.

94 De kundigen wiegen het op en neer, de bekwamen bewegen het hierheen en daarheen, degenen, die rijk van geest zijn, dragen het op de hand, de kundigen melodiëren steeds door.

$95 \mathrm{Mijn}$ binnenste popelt, mijn hart is als het ware bewolkt, mijn lichaam siddert, mijn haren rijzen te berge.

$96 \mathrm{Bij}$ het horen van het kolken van de zee, het gebruis van de wateren, het zieden van het schuim, beweeg ik mij als een school met wier bedekte vissen.

93 "toen wij kinderen waren", nl. en in het water speelden.

94 In regel a slaat "het" op het gezang. In regel b luidt de variant: nabantan rangga inaa: degenen, di $\epsilon$ rijk van geest zijn houden het op de schoot. 
97 Tipadingin-dinginomo', menaa tang liuomo', ma'pu' panallanganomo'.

98 Madingin nasilo allo, ma'pu' natandere liku, nasarombon bura-bura, naarrang liku mandalan.

99 Saemo anginna Bone, kuba-kubanna Balanda, sarussu'na randan langi', bara'na lelean uran.

100 Pada masso sae lembang, pada titongka orongan, pada lempan koli-koli.

101 Titua' tungkamo lembang, tibalintanmo orongan, tibibi'mo koli-koli'.

102 Tibaliang lembang sura', tibibi' lopi bulajan, lempan koli-koli manik.

103 Masso saemi anginna, ta'gulingmo penaanna, sombomo pasiruanna.

104 Saemo lembang saratu', orongan sangkamo-kamo, lembang sangsa'bu situru'.

105 Tallu ratu' sangke'deran, sangsa'bu sangtiangkaran, samma' sangpenggaluguan.

106 Kukalle-kallei aku, pusa'na' umpenajanni, umbarang tang paissanni.

97 "Ik gevoel mij weer door koude rillingen aangegrepen"; dit is, omdat de geest in haar vaart.

100 titongka, $1 \mathrm{tl}$. in éen uitgieting neervallen van water, dat uitgegoten wordt; de betekenis hiervan is: met $z^{\prime} n$ allen, te zamen met elkaar komen aanvaren.

104 In regel $c$ is de tekst van de variant gevolgd; E Ia heeft Zembang sangsa'bu saratu': duizend honderd prauwen. 
97 Ik gevoel mij weer door koude rillingen aangegrepen, weer in het geheel niet ademend, ik ben weer aan het zweten als een bamboe (die verbrand wordt).

98 Koud zijnde verblind door het licht van de zon, zwetend door de diepe kolk in de hoogte gehouden, door het schuim bestoven, beschenen door de diepe kolk.

99 Bonese wind is gekomen, het nu eens helder, dan weer dof klinkend geluid der Hollanders, de warme luchtstroom van de rand van de hemel, de hevige wind van de plaats, waar de regen vandaan komt.

100 Gelijkelijk gaan en komen er prauwen, met $z^{\prime} n$ allen komen de vaartuigen, in overstromende menigte komen de schuitjes.

101 Met $z$ 'n allen komen de prauwen, de vaartuigen tuimelen om, de schuitjes raken onderste boven.

102 Omgekeerd raken de met snijwerk versierde prauwen, ondersteboven raken de gouden vaartuigen, in overstromende menigte komen de schuitjes, fraai als kralen.

103 Gelijkelijk komt en gaat haar adem, haar adem keert weer terug, haar daden worden zichtbaar.

104 Er zijn honderd prauwen gekomen, ontelbaar vele vaartuigen, duizend op elkaar volgende prauwen.

105 Driehonderd vertrekken er met elkaar, duizend steken er in één groep af, met elkaar een machtig gedreun.

106 Wat mij aangaat, ik ben er verbaasd over, ik ben verbijsterd er over nadenkend, ik gis er naar zonder het te weten. 
107 Lembang tang tasik naola, tang panompok naorongi, tang sa'dan nakulea'i.

108 Lolok buntu naorongi, tanete nakulea'i, rante natontonan raki'.

109 Tang pemaliraka ia, tang pepaju padangraka?

110 Mellolok buntumo lembang, mentanetemo orongan, mennaja'mo koli-koli.

111 Rano-ranoammo buntu, ambollongammo tanete, lendongammo kamanglean.

112 Napolalan sae lembang naola ratu orongan, ke'de' sae koli-koli.

113 Lolok buntu bintoenan, kumila' asi-asian, rante darepe-repean.

114 Langi' diongki leu, bintoen kisalembe'mo, allo kilese rokkomo.

107 panompok: sawahdijk; in d.t. heeft het vaak de betekenis van: sawah.

nakulea'i, 1t1. zij zwemmen er over door beurtelings de armen uit te slaan.

108 raki' is een uit 4 of 5 planken bestaand vlot, waarmee men aarde in de sawah verplaatst.

109 pepaju: hetgeen zwaar tegen de adat indruist en onheil aanbrengt.

113 darepe, $1 \mathrm{tl}$. een ontploffend geluid geven van gepofte rijst- en maiskorrels; hier gebezigd naar analogie van het woord ra'tuk: gepofte rijstkorrel, die open springt, zodat het witte binnengedeelte gaat uitzetten; ra'tuk $2 a n g i^{\prime}, 1 t 1$. gepofte, open springende rijstkorrel van het uitspansel, is een dichterlijke benaming van ster.

Tussen de strofen 113 en 114 heeft de variant nog twee strofen, luidende:

La kakajuammo Zangi',

la kapadang-padangammo,

tang kabintoenamo: 
107 Prauwen, die niet over de zee gaan, die niet over de sawah varen, die de rivier niet oversteken door te pagaaien.

$108 \mathrm{Zij}$ varen over de toppen der bergen, men pagaait hen over de bergen heen, zij gaan als vlotten dwars over de vlakte heen.

109 Is dat niet verboden volgens de adat, is het niet iets afschuwelijks, dat onheil over het land brengt?

110 Over de bergtoppen gevaren zijn de prauwen, de vaart van de vaartuigen was over de bergen, langs de berghellingen zijn de schuitjes gekoerst.

111 Begroeid met waterplanten zijn de bergen, vol waterplanten met paarse bloemen zijn de gebergten, vol aaltjes zijn de hoogten.

112 De prauwen komen er over heen gaande, de vaartuigen arriveren er over heen varende, de schuitjes vertrekken en komen aan.

113 De bergtop is vol sterren, het ravijn is met gesternte bezet, de vlakte is vol uitstralende lichten.

114 Het uitspansel is ginds onder ons, onze voeten blijven steken in de sterren, de zon betreden wij onder ons.

Het uitspansel zal vol geboomte zijn, het zal met velden bedekt zijn, het zal niet vol sterren zijn. Batu papan bintoenan, kumila' asi-asian, rante darepe-repean:

Het stenen plateau is vol sterren, het ravijn is met gesternte bezet, de vlakte is vol uitstralende lichten.

114 en volgende strofen. De beschrijving van de tocht der in trance verkerende vrouwen door het luchtruim bevat trekken, die men ook aantreft in de zang der priesteressen, de tadu mburake "voorgangsters der luchtgeesten" der Bare'e-sprekende Toradja's, in welke de tocht beschreven wordt die de priesteres door het luchtruim maakt in de als boot dienstdoende regenboog, om de zielestof van een zieke uit de bovenwereld terug te halen, zie Adriani, V.G. II, p. 207vv. en Adriani-Kruyt (2e dr., 1951), II, p. 123-139. 
115 Mematu-matumo lembang, kumanassakmo orongan, memonganmo koli-koli.

116 Tang pemaliraka ia, tang pepaju padangraka?

117 Lembang bolong sae bongi, tampak rarran te malillin, kila' merrassa dannari, la'te songlo' oni manuk, ramban ma'kukkua londong.

118 Tang tandanrika lembangna, bali tang issanandika?

119 Mambelako unnissanni, langkako umpelelei, umpelele karoenni, unnissan tangnga bongii, umpemangka kumandei.

120 Lembang siaraka lembang, orongandaka orongan, raki'raka koli-koli?

121 Lembang dipapai bajak, ditarampakki mataran, diosokki oda-oda.

122 Tonapa landa longana, digajang patomalinna.

123 Unnesungmo' ri laja'na, tongkonmo' i panimbana, daomo' landa longana.

124 Umpekati-kati tumbang, umpelolosu malangi', umpesondong sala padang.

121 bajak: het scherpe gedeelte van het lemet van een zwaard of een mes, in d.t. zwaard. - Men vindt deze prauwen met zwaarden als dakbedekking en het scherpe als dakrand vermeld in het Verhaal van Pano Bulaan, zie Van de Loosdrecht en Adriani (1914), p. 225-244.

124 kati-kati $=$ Zoti'-Zoti': het hoogste punt van de kruin van een boom. 
115 De prauwen dreunen voortdurend, de vaartuigen knallen als donderslagen, de schuitjes geven een bonzend geluid.

116 Is het niet verboden volgens de adat, is het niet iets afschuwelijks, dat onheil over het land brengt?

117 De zwarte prauwen komen in de nacht, deze duisternis is die van het einde van de nacht, de bliksem knettert in de nanacht, de bliksemflitsen schieten neer, wanneer de kippen hun geluid doen horen, gelijktijdig kraaien de hanen.

$118 \mathrm{Zijn}$ hun prauwen niet bekend, is er niets te weten omtrent de makkers?

119 Wanneer je ver weg gaat, zul je het weten, wanneer je op grote afstand bent, zul je er van horen, je zult er van horen in de avond, je zult het weten te middernacht, je moet wachten tot men klaar is met eten.

$120 \mathrm{Zijn}$ de prauwen wel prauwen, zijn de vaartuigen vaartuigen, zijn de schuitjes vlotten?

121 Het zijn prauwen met zwaarden als dakbedekking, de dakrand is gedekt met het scherpe, er zijn scherpe wapens in gestoken.

122 Korte zwaarden zijn de overhellende plechten, aan beide zijden voorzien van gouden krissen.

123 Ik ben reeds gezeten op de achterplecht, ik heb mij gezet onder het afdak, ik ben nu reeds boven op de plecht.

124 Het voert het in bovenaardse toestand zijn tot het hoogste punt, het doet het in vervoering zijn ten top stijgen, het drijft het de grond niet mogen betreden op de spits. 
125 Angki kalandona tumbang, angki lajukna malangi', tarangsona sala padang, linggi'na kandeatan.

126 Diong to umbala lembang, to umpamaki orongan, to umbintan koli-koli.

127 Beluak apapa inde, rundun mindapa umbenna', mangka diporian lembang, dibintanan koli-koli? Diala tallu orongan.

128 Natabu-tabumo puang, nasaeranmo deata, nasampanmo to menampa.

129 Natabu-tabu tang tedong, nasaeran tang kanae, nasampan tang karambau.

130 Napantiti'mo atena, nasanggingmo sumusunna.

131 Napantiti' tang nakande, nasangging tang napoapa, nasisorong-soronganni, nasiparunggu-runggui.

132 Napantiti' rokko lembang, nasangging rokko orongan, napadiong koli-koli.

133 Penduan ponnomo lembang, pentallun kapalinammo, la'bimo bose bulaan.

Tussen de strofen 126 en 127 heeft de variant nog de volgende strofe: Mareko mambala lembang, mamak tumaki orongan, umbalantan koli-koli:

Zij maken rumoer bij het bekappen van de prauwen, $z i j$ zijn luidruchtig bij het omwikkelen van de vaartuigen, $z i j$ omwikkelen de schuitjes een voor een.

130 napantiti' heeft de technische betekenis van: men neemt een stukje van de lever en andere vleesdelen van een tijdens het dodenritueel geslacht dier en biedt dit aan de ziel van de dode aan. Wij nemen het hier in de algemenere betekenis van: een stukje nemen van de 
125 Dat wij het toppunt zijn van het in bovenaardse toestand verkeren, dat wij het hoogste zijn van het in vervoering zijn, het hoogste punt van het de grond niet mogen betreden, de hoogste top van het door een geest bezeten zijn.

126 Daar beneden zijn de lieden, die de prauwen bekappen, die de vaartuigen omwikkelen met repen rotan, die de banden om de schuitjes binden.

127 Wat voor haar is dit?

Wie zal mij het loshangend haar geven, waarmee de prauwen gebonden zijn, die als banden om de schuitjes zijn gelegd?

Er werden drie vaartuigen gehaald.

128 De heren verstrooien ze, de geesten verspreiden ze, de scheppende goden snijden ze in stukken.

$129 \mathrm{Zij}$ verstrooien ze, die geen buffels zijn, $z i j$ verspreiden ze, die geen karbouwen $z i j n$, $z i j$ snijden in stukken hen, die geen buffels zijn.

$130 \mathrm{Zij}$ nemen een klein stukje van de lever,

zij snijden het hart in dikke plakken.

$131 \mathrm{Zij}$ nemen een klein stukje zonder het te eten, $z i j$ snijden in dikke plakken, maar doen er niets mee, zij geven het aan elkander over, zij dringen er bij elkaar op aan om het eerst iets te doen.

$132 \mathrm{Zij}$ nemen een klein stukje en brengen het in de prauw, zij snijden het in dikke plakken en doen het in het vaartuig, $z i j$ leggen het neer in het schuitje.

133 De prauw is tweemaal zo vol, driemaal gaat het er over heen, het gouden vaartuig heeft meer lading dan het kan bevatten.

lever of ander vleesdeel van een geslacht dier. sumusunna is een substantivering van de werkwoordsvorm sumusu: aan de borst zijn; volgens dhr. Tammu is het hier gebruikt in de $z$ in van: "wat kleeft aan, wat tegen iets aan ligt, zoals de zuigeling aan de borst van de moeder" (vgl. de uitdrukking padang sumusu tama tasik: land, dat tegen de zee aankleeft, kaap); in dit verband is het dan gezegd van vleesdelen in het binnenste van het lichaam, het zou dan "hart", "longen" of "lever" kunnen betekenen. Wij hebben gekozen voor de betekenis van hart.

133 bose, 1tl. schepriem; hier als pars pro toto in de betekenis van: vaartuig. 
134 Anna rampanammo' rokko, anna batang sorongammo', anna tang umpoapamo'.

135 Maleora nalembangan, liura napaumbose, napasalako-lakona, natontonan dua raki', naola tallu orongan.

136 Indo' $1 \mathrm{e}$, to kumombong $\mathrm{e}$ ! to mendadian e. to meparede rara'i, to mekombong bulajanni, meligi' ponto lola'i.

137 Rampanammo' angku male, tangga'mo' angku la 1ao, angku salako-lakona.

138 Angku parandena Goa, angku tandinna Balanda, peassa'na randan langi', langda'na lelean uran.

139 Lambanomo', sojanomo', manarru' mambelaomo', rengke'mo', seseanomo' .

140 La rundu' salumo' rekke, la karangan-karanganmo', randuk ma'tete uai.

141 Ullambi'mo salu tumbang, uai kandeatan, sepang tang kantolinoan.

142 Salu sitammu sepangna, sisarangnga sarambunna, siserok umbanasanna.

143 Umbanassa ten karaeng, unnumbuk tempaja padang, lao ten $1 a^{\prime}$ te mamara.

138 peassa' is de dunne balk, die langs de voor- en achtergevel van het huis loopt; in de daarin gehakte openingen worden de dikke planken gestoken tussen welke de wand van het huis gevoegd wordt. 142 sarangnga': averechts, tegen de draad in. 
134 Zodat zij mij naar beneden loslieten, zodat zij zelf mij wegstieten, en zich niet om mij bekommerden.

$135 \mathrm{Zij}$ gingen weer het in een prauw vervoerend, ginds weer deden ze het al pagaaiende voortgaan, zij deden ze maar steeds voortgaan, $z i j$ gingen regelrecht in twee schuitjes, zij bestegen drie vaartuigen.

1360 Moeder, schepper toch!

formeerder toch, die ons op luisterrijke wijze deed ontstaan, die ons op gouden wijze schiep, die ons formeerde op de wijze van een grote gouden armband:

137 Laat mij vrij, dat ik ga, sta mij toe, dat ik zal heengaan, dat ik hoe langer hoe verder ga.

138 Dat ik zij de balk op welke Goa rust, de stut van het land der Hollanders, de steunbalk van de horizon, de schraag van de plaats waar de regen vandaan komt.

139 Ik ga weer op iets anders over, ik ben weer vervaard, $i k$ ben al rechtdoor ver weggegaan, ik ben al dicht bij, ik ben al tot de helft.

140 Ik ga de rivier stroomopwaarts volgen, ik ga over het grind lopen, ik begin over het water te lopen.

$141 \mathrm{Ik}$ heb de in bovenaardse toestand verkerende rivier bereikt, de vloed door een geest bezeten, de niet tot deze wereld behorende oever.

142 De rivier, die tegen de helling oploopt, die tegen zijn stroomversnelling in loopt, die niet omkijkt naar zijn neerstorting.

$143 \mathrm{Hij}$ stort neer als een vorst, hij zinkt onder de oppervlakte als een luisterrijke des lands, hij is als een bliksem, die neerschiet zonder dat er regen is.

143 tempaja $=$ pempaa, $1 \mathrm{t} 1$. veren van de paradijsvogel, die als versiersel gebruikt worden. la'te mamara, 1tl. bliksemflitsen in de drogetijd. 
144 Salu tang balle bunginna, tang leaga karanganna, tang pinda batu-batuanna.

145 Tinggi ma'misa bunginna, batu rara' karanganna, letoan batu-batunna.

146 Uai limbong kaise', liku ma'tan danga-danga.

147 Pendauranna to tumbang, ukkunanna to malangi', pekkulea'-learanna.

148 Uai sanglampa borrong, sangparajan mean-mean, sangpati' mendila-dila.

149 Kukalle-kallei aku, pusa'na' umpenajanni, umbarang tang paissanni.

150 Uai nakande api, sa'dan nalalle ruaja, nanennek ma'lala-lana.

151 Tindak sarira rambunna, mian kila' lalatunna, sundallak rambu rojana.

152 Lalatunna mepatumbang, rambunna mepamalangi' meparuntuk sala padang mepaloo kandeatan.

153 Lambanomo', sojanomo', manarru' mambelaomo', rengke'mo', seseanomo'.

144c De variant luidt: tang ZeZuk batu-batuanna: welks steentjes zich niet verplaatsen.

146 kaise' is een struik met rode vruchten, die de vorm hebben van areca-noten; Indon. kesumba, Bixa orellana. danga-danga: rode bloem, een soort gladiolus; ook wordt de kembang sepatu wel danga-danga genoemd.

147 a De variant luidt: pendioranna to tumbang: de badplaats der in bovenaardse toestand zijnden. 
144 Een rivier, welks zand onbedriegelijk is, welks grind niet beduusd is, welks steentjes niet veranderen.

$145 \mathrm{Zijn}$ zand bestaat een en al uit donkerrode kralen, zijn grind zijn de met goud overtrokken klossen van het halssieraad, zijn steentjes het driedelige halssieraad.

146 Het water van de plas bestaat uit kaise'-struiken, de rustig vloeiende kolk bestaat uit danga-danga-planten.

147 De plaats om zich het gezicht te wassen van de in bovenaardse toestand verkerenden, de plaats van onderduiken der in vervoering zijnden, de plaats waar zij overzwemmen door beurtelings de armen uit te slaan.

148 Een geleding vol rood-glanzend water, een vat vol hetgeen vonken schiet, een afgehakt stuk, dat schittert.

149 Wat mij aangaat, ik ben er verbaasd over, $i k$ ben verbaasd, wanneer ik er over nadenk, ik gis er naar zonder het te weten.

150 water door het vuur verteerd, vocht door de gloeiende kool verzengd, het breidt zich steeds opvlammend uit.

$151 \mathrm{Zijn}$ rook is een regenboog, zijn vonken zijn bliksemschichten, flitsend is de rook van zijn kolenvuur.

$152 \mathrm{Zijn}$ vonken wekken de in bovenaardse toestand verkerende op, zijn rook wekt de in vervoering zijnde op, $z i j$ jagen het de grond niet mogen betreden na, $z i j$ brengen het de geest in zich hebben aan de gang.

$153 \mathrm{Ik}$ ga weer op iets anders over, ik ben weer vervaard, $i k$ ben al rechtdoor ver weggegaan, ik ben al dicht bij, ik ben al tot de helft.

150 In d.t. heeft sa'dan de betekenis van: water. Dit zal de oorspronkelijke betekenis zijn van de naam van de rivier de Sa'dan. In de Westelijke streken van het Rantepaose en het Ma'kalese wordt de Masuppu', de zijrivier van de Sa'dan, ook Sa'dan genoemd.

152 De variant luidt in regel d: mepaloo timbajo kila': zij brengen het flitsen van de bliksem aan de gang. 
154 Lamban 1ianmo' sepangna, sambalinmo' minangnganna.

155 Dibala bembemo' lian, disarassang penaimo', dirompo mata dokemo'.

156 Mata doke diorongi, mataran dikulea'i, bajak ditontonan raki'.

157 Lambanomo', sojanomo', manarru' mambelaomo', rengke'mo, seseanomo'.

158 Lamban 1ianmo' Malangke', sambalinmo' Daja-Daja, tondok randan Bone-Bone.

159 To umbone-bone pindan, to umbilanda banaja.

160 To kumombong sariajan, rumende kandian gallang.

161 Lambanomo', sojanomo', manarru' mambelaomo', rengke'mo', seseanomo'.

162 Sambali 'mo' tana dondan, rante tikallebo tuka', lombok tojang ruaka'na.

163 Rante pa'tengkoan kila', pangebangan sudu landu', randukan isi mangea.

164 Lambanomo', sojanomo', manarru' mambelaomo', rengke'mo', seseanomo'.

155 sarassang: versiering van uitgeplozen jonge bladeren van de suikerpalm, door de vrouwen op het bugi'-feest om het middel geslagen. In dit verband zijn dat dus zwaarden.

158 De verdubbelde vorm Bone-Bone bevat een woordspeling op het woord umbone-bone van de volgende strofe.

162 tana dondan: volgens de Heer Tammu heeft dit de betekenis van: streken, die elkaar achterna jagen, d.i. streken met verschillende bergtoppen, die als het ware achter elkaar aanzitten; hij citeert de uitdrukking talo dondan in de simbong-zang uit het landschap Pangala', elders talo-talo siula' luidend: in troepjes achterna jagen. 
154 Ik ben reeds naar de overzijde naar de oever er van overgestoken, naar zijn uitmonding aan de overzijde.

$155 \mathrm{Ik}$ ben aan de overzijde omheind door stokken met pluimen van geitenhaar er aan,

ik ben aan het middel ombonden met zwaarden,

ik ben ompaald door lanspunten.

156 Een lanspunt wordt als drijfhout gebruikt, het scherpe wordt gebezigd om er op te zwemmen met beurtelings uitslaan van de armen, met het lemmet als vlot wordt er recht op afgegaan.

157 Ik ga weer op iets anders over, ik ben weer vervaard, ik ben al rechtdoor ver weggegaan, ik ben al dicht bij, ik ben al tot de helft.

158 Ik ben reeds overgestoken naar Malangke', naar de overzijde naar Java, naar de plaats aan de rand van Bone.

159 De lieden, die de borden zwart maken met de bast van de bone-boom, die de uitgeholde kommen maken.

160 Die de belletjes van geel koper vervaardigen, die de koperen etensschalen smeden.

161 Ik ga weer op iets anders over, ik ben weer vervaard, ik ben al rechtdoor ver weggegaan, ik ben al dicht bij, ik ben al tot de helft.

162 Ik ben reeds aan de overzijde aan de streken, die elkaar achterna jagen, de vlakte, die omhoog stijgt, een dal welks wortels zich ver uitstrekken.

163 De vlakte waar de bliksem heen en weer ploegt, de plaats, die omgewerkt wordt door het weerlicht, waar de weerstand biedende tanden in gestoken worden.

$164 \mathrm{Ik}$ ga weer op iets anders over, ik ben weer vervaard, $i k$ ben al rechtdoor ver weggegaan, ik ben al dicht bij, ik ben al tot de helft.

maka' = uaka': wortels; een dal welks wortels zich ver uitstrekken heeft de betekenis van: een dal welks vlakte zich ver uitstrekt voordat men het gebergte bereikt. 
165 Sambalinmo' pelangiran, di lombok pekkulearan, rante pa'dambualaran.

166 Nang inanna tau 1i'pang, tondokna tau leaga.

167 Napaleaga puangna, napali'pang deatanna, pong anak to tibojongna.

168 Lambanomo', sojanomo', manarru' mambelaomo', rengke'mo', seseanomo'.

169 Diongmo' dadaran pindan, pange'teran kalussaja, rampoan batu unnajang.

170 Nang inanna to isura', bangkula' dipare-pare, pindan dimangkai bone.

171 To mpare-pare bangkula', to ungkombong sariajan, rumende kandian gallang.

172 Lambanomo', sojanomo', manarru' mambelaomo', rengke 'mo', seseanomo'.

173 Disirussun-russunanni, disisorong-soronganni, disiparunggu-runggui.

174 Ilalanmo tangnga to'dang, diminanganna indarro.

175 Nasikatangkai lembang, nasialla'i orongan.

176 Nasisorong-soronganni, nasiparunggu-runggui.

165 pa'dambualaran is een afleiding van dambuala': een djamboe-soort met veel pitjes.

169 rampoan batu unnajang, $1 \mathrm{tl}$. de plaats, waar de stenen drijvende aankomen.

172 Deze strofe ontbreekt in de variant.

174 Het woord indarro is ons niet bekend. 
165 Aan de overzijde op de plaats, waar men het haar wast, in het dal, waar men zwemt met het beurtelings uitslaan van de armen, de vlakte, waar men de wilde djamboe haalt.

166 Zeer zeker de plaats van hen, die verbluft zijn, het dorp van hen, die beduusd zijn.

167 Hun heer maakt hen verbluft, hun god doet hen beduusd zijn, de heer van de kinderen van hen die door schrik zijn opgejaagd.

$168 \mathrm{Ik}$ ga weer op iets anders over, ik ben weer vervaard, ik ben al rechtdoor ver weggegaan, ik ben al dicht bij, ik ben al tot de helft.

$169 \mathrm{Ik}$ ben reeds beneden op de plaats, waar de schalen op een rij staan, de plaats, waar de porceleinen voorwerpen met leguaan-figuren in een rij liggen uitgestrekt, de plaats, waar de borden komen aandrijven.

170 Zeer zeker de plaats van dat, wat met figuren versierd is, de koperen klokjes van franje voorzien, de schalen, die zwart gemaakt zijn.

171 De lieden die de koperen belletjes van franje voorzien, die de belletjes van geelkoper vervaardigen, die de koperen etensschalen smeden.

172 Ik ga weer op iets anders over, ik been weer vervaard, ik ben al rechtdoor ver weggegaan, ik ben al dicht bij, ik ben al tot de helft.

$173 \mathrm{Zij}$ worden van alle kanten bijeengeduwd, zij worden van alle kanten bijeengeschoven, zij worden van alle kanten bijeengedrongen.

174 Ik ben halverwege bezig rustig te vertoeven, bij de uitmonding van ...

$175 \mathrm{Zij}$ klemmen de prauwen van verschillende zijden in, $z i j$ stellen een tussenruimte tussen de vaartuigen.

$176 \mathrm{Zij}$ dưwen ze van alle kanten bijeen, zij dringen ze van alle kanten bijeen. 
177 Mengkendekmo' ri lebukan, langnganmo' i lantang bola, langgara' kusalongimo.

178 To masaung manna lan, to mosibintean manna, to unnaran manuk-manuk.

179 Manuk tang kumande barra', tang rumintok buang-buang.

180 Bulaan manna kandena, rara' sea'-searanna.

181 Urratuimo' sala'bi', ullambi 'mo' baladada'.

182 Tainamo' rante baine, dibuku lampa pasondok.

183 Limbong rara diorongi, lomba' dipekulea'i.

184 Ma'keara' dipatumbang, sengke mepamalangiran.

185 Morai mendio' rara, membollo-bollo malea, la sumimbong rara tau.

186 La merrandanmo-merrandan, tungka la mengkareke'mo.

187 La randukmo mempangala', la tama kakajuanna, dibatang situlambenan.

188 Narombe-rombei bolo', natiantenni katimbang.

189 Nasa'pekki bua ue, bua ue ri Sesean.

190 Katimbang ri Lindotau, pondan di Batumaetan.

177 bola, het Buginese woord voor huis, wordt in die betekenis ook in het Zuidtoradjaas in d.t. gebezigd.

188 De bolo'-heester, die langwerpige vruchten heeft als van kapok, groeit in het bos, misschien Talauma ovalis.

190 Lindotau: "Gelaat van een mens" en Batumaetan: "Zwarte Rots" zijn benamingen van het Sesean-gebergte. 
177 Ik ben opgeklommen naar het eiland, opwaarts naar de hutten en huizen, ik ben naar het huis met een vierhoekig dak gegaan.

$178 \mathrm{Er}$ waren slechts mensen in, die hanen lieten vechten, die hen elkaar in de veren lieten vliegen, lieden, die vogels lokten.

179 Kippen, die geen gestampte rijstkorrels eten, die het uitgestrooide voedsel niet oppikken.

180 Goud slechts is hun voedsel, de gouden klossen van het halssieraad is hetgeen voor hen gestrooid wordt.

181 Ik ben reeds gekomen tot de omheining van gespleten kruiselings tegen elkaar staande bamboe, ik heb de omheining van rechtopstaande bamboelatten bereikt.

182 Ik ben het veld der vrouwen opgegaan, het water komt tot aan het dijbeen.

$183 \mathrm{Er}$ werd door een grote plas bloed heen gezwommen, er werd door veel vloeiend bloed heen gezwommen met het beurtelings uitslaan van de armen.

$184 \mathrm{Zij}$ zijn toornig bij het in bovenaardse toestand gebracht worden, $z i j$ zijn vergramd in vervoering gebracht wordende.

$185 \mathrm{Zij}$ willen in bloed baden, $z i j$ trachten $z i c h$ te overgieten met het rode, $z i j$ wensen te plonzen in mensenbloed.

$186 \mathrm{Zij}$ willen reeds steeds meer naderen, zij willen echt naderbij komen.

$187 \mathrm{Zij}$ beginnen al in het bos te lopen, zij willen het geboomte al in, over de omgevallen boomstammen, die dwars over elkaar liggen.

$188 \mathrm{Zij}$ versieren ze als franje met de vruchten van de bolo'-heester waarin $z i j$ een rode pauwveer met groen er doorheen leggen.

$189 \mathrm{Zij}$ rukken rotanvruchten af, rotanvruchten van de Sesean.

190 Pauwveren zijn van Lindotau, ananasbladeren van Batumaetan. 
191 Ussalo-salomo' pondan, unnelakmo' bua ue, katimbang kusalongimo.

192 Tillo'-tillo'ri dandalo, unnoniri manuk-manuk, metekri dassi londongna.

193 Kutangnga-tangngai tama, kupaduang sisamanni.

194 Metamba-tambai saa, kumukkuari arae.

195 Unnoniri manuk-manuk, metekri dassi londongna.

196 Bunga' petambana puang, randuk oninna deata.

197 Metamba i tallang bunu', megalugu kabombongan, meunduk tandi anak dara.

198 Unnesungimo' bombongna, tongkonmo i palapana, daomo' londe daunna.

199 Umpekati-kati tumbang, umpelolosu malangi', umpesondong sala padang.

200 Angki kalandona tumbang, angki lajukna malangi'.

201 Tarangsona sala padang, linggi'na kandeatan.

192 Het woord dandalo heeft de informant niet weten thuis te brengen. Misschien is het in betekenis gelijk te stellen aan alo: rinocerosvogel.

dassi: een vogel met gele veren en rode borst, die op de bloemtros van de suikerpalm af komt, wanneer daar palmwijn van getapt wordt.

194 kumukkuari: aldus de variant, E Ia heeft kumukuari; kumukkua is een -um-vorm van kukkua: een kraaiend geluid geven. arae is een slang met een kam op de kop als die van een haan.

197 tallang bunu': jonge bamboe, waar banden van afgeschild worden. anak dara (1tl. maagd, jonge vrouw) is de bundel van 4 stukken bamboe, aan welke allerlei bladeren zijn bevestigd, die aan de middelste hoofdpaal gebonden worden in het huis van degene, die het hua' kasalle = la'pa' kasalle-feest houdt. 
191 Ik loop tussen de ananasbladeren door, $i k$ beweeg mij tussen de rotanvruchten, bij de pauwveren wandel ik rond.

192 Het zachte geluid bij de rinocerosvogels, de vogels tjilpen, het mannetje van het honingzuigertje fluit.

193 Ik ga er midden in, ik scheid ze in twee delen.

194 De pythonslang roept, de arae-slang geeft een kraaiend geluid.

195 De vogels tjilpen, het mannetje van het honingzuigertje fluit.

196 De aanvang van het roepen van de heer, het begin van het geluid van de geest.

$197 \mathrm{Hij}$ roept tot de jonge bamboe, waar banden van afgeschild worden, het korte schopje, waarmee gewied wordt, geeft een dreunend geluid, hij gaat in de lengte langs het steunsel naar boven naar de anak dara.

198 Ik zet mij neer op de nerf ervan, ik ga zitten op zijn rib, $i k$ ben boven op het vaartuig van zijn bladeren.

199 Het voert het in bovenaardse toestand zijn tot het hoogste punt, het doet het in vervoering zijn ten top stijgen, het drijft het de grond niet mogen betreden op de spits.

200 Opdat wij in de hoogste mate in bovenaardse toestand zouden zijn, tot de opperste vervoering zouden komen.

201 Het krachtigste van het de grond niet mogen betreden, het geweldigste van het de geest in zich hebben.

198 De Heer Tammu veronderstelt, dat mogelijk in de oude tijd in de tongkonan, in welke het maro-ritueel een aanvang ging nemen, een anak dara was aangebracht als een teken, dat zo'n maro-feest een voorbereidende rite was voor het later te verrichten $Z^{\prime}{ }^{\prime} p a^{\prime}$ kasallefeest. Volgens hem worden de in trance komenden op de plaats van de anak dara door de geest bezeten tijdens het maro-feest. Dit voorwerp zou dan zowel bij het maro- als bij het bua' kasalle-ritueel de verbindingsweg vormen tussen de middenwereld en de bovenwereld.

201 linggi' betekent: een aanzienlijk man. In de ge Zong maro komt de uitdrukking voor: Za napada'dua linggi': 'hij moge hem doen zijn als twee mannen van gewicht"; dit wordt gewenst voor het in trance komen van een aanzienlijk man; zie voorts $W b_{0}, p .313 a$. 
Randukmo to tu to maro unnondo.

202 Sidi'-sidi' angku bajan, sakkodo' angku bugiran.

203 Angku tumende i batang, angku lamban lolok kaju.

204 Dao sanglallean bajan, sangtotokan manuk-manuk, sangta'pan bugiran daja.

205 Lambanomo', sojanomo', manarru' mambelaomo', rengke'mo', seseanomo'.

206 Diongmo' sangtondok nuang, sangpasangan bai lampung.

207 Nang inan donga menduruk, pengkalabu'-laburanna.

208 Lambanomo', sojanomo', manarru' mambelaomo', rengke'mo', seseanomo'.

209 Ullambi 'mo' buntu borrong, tanete ma'lana-lana, lombok merambu laulung.

210 Nang inanna puang la'pa', deata mangka manglili', datu songlo' daja mai.

211 Malle malingra' sisumbung, leagara' siperupa, $1 i$ 'pangra' sitau mata.

212 Apara tang la leaga, tang la maling inajangku!

213 Puang malea ulunna, datu borrong beluakna.

214 Paarrang lisu matanna, borrong passimbolonganna.

202 bugiran is een vogeltje met geel-groene veren. Het woord bevat een zinspeling op het woord bugiran: door een demon (bugi') bezeten zijn.

206 nuang is de Anoa depressicornis.

210 "de goden, die de grenzen bepalen", nl. van het in hun machtssfeer gelegen gebied, dat taboe is voor hen, die leven onder de bepalingen van de rouwgebruiken van het dodenritueel. 
De lieden, die het maro-feest vieren, gaan nu dansbewegingen maken met doorgebogen knieën in snel tempo opspringend. a)

202 Bijna word ik een parkiet, het scheelt weinig, of ik word een bugiran-vogeltje.

203 Dat ik op een boom ga hippen, dat ik naar een boomkruin ga overwippen.

204 Daar is een zwerm parkieten, die op elkaar bijten, een koppel vogels, die op elkaar inpikken, ginds zetten de bugiran-vogels zich met elkaar neer.

205 Ik ga weer op iets anders over, ik ben weer vervaard, $i k$ ben al rechtdoor ver weggegaan, ik ben al dicht bij, ik ben al tot de helft.

$206 \mathrm{Ik}$ ben al beneden in eenzelfde streek met de bosantilopen, op eenzelfde weideplaats met de wilde varkens.

207 Stellig de plaats van de herten, waar zij hun voedsel zoeken, de plaats, waarheen $z i j$ verdwijnen.

208 Ik ga weer op iets anders over, ik ben weer vervaard, ik ben al rechtdoor ver weggegaan, ik ben al dicht bij, ik ben al tot de helft.

209 Ik heb een rood-gloeiende berg bereikt, een hoog-opvlammende heuvel, een dal, dat een blauw-zwarte rook verspreidt.

210 Zonder twijfel de plaats waar de heren zich voor het slotritueel in optocht heen begeven, de goden, die de grenzen bepalen, de geesten, die uit het Noorden zijn neergedaald.

211 Ik ben verbijsterd en vervaard bij het aaneenvoegen, $i k$ ben verbluft om de juiste figuren onderling te bepalen, ik ben beduusd als mensen onderling tegenover elkaar.

212 Maar zou men niet verbluft zijn, zou mijn geest niet vervaard zijn!

213 Heren, wier hoofd rood is, goden, wier haren rood gloeien.

214 Stralend is de appel van hun ogen, de plaats van hun haarwrong is rood-gloeiend.

a) Het ritme van de zang krijgt bij deze overgang een hossend karakter. 
215 To tuo langngan rundunna, to sumissang beluakna.

216 Paarrang lisu matanna, borrong passimbolonganna.

217 Ma'beluak kollo-kollo, ma'isi dakka i Daja.

$218 \mathrm{Ma}$ 'patondon loe manik, massella' la'te mamara.

219 Kukalle-kallei aku, pusa'na' umpenajanni, umbarang tang paissanni.

$220 \mathrm{Ma}$ 'kundai tang naissan, ma'dodo nakamallei, nakamalle ngkamalingi.

221 Nakatumanga-mangai, nabarang tang paissanni.

222 To ungkamallei suru', tang unnissan sarak rundun.

223 Ditoma'dekkai suru', ditotangmarro ma'kada.

224 Lambanomo', sojanomo', manarru' mambelaomo', rengke'mo', seseanomo'.

225 U1lambi'mo' padang toni', tondok tang kakajuanna, tang dibangunni banua.

226 Kaluppini' manna rorak, bu'ku' silongsean manna.

227 Salong-salonganna nuang, pa'gessengan bai lampung.

228 Nang inan donga menduruk, pengkalabu'-1aburanna.

229 Lambanomo', sojanomo', manarru' mambelaomo', rengke'mo', seseanomo'.

217 kolzo-kolzo is een slingerplant met gebogen stengel als de steel van de bloemkolf van de suikerpalm.

223 "die in hun plaats zacht spreken", d.i. omdat zij zelf niet anders dan met harde stem spreken. 
215 Lieden, wier haren omhoog groeien, wier haren tegen de draad in groeien.

216 Stralend is de appel van hun ogen, de plaats van hun haarwrong is rood-gloeiend.

$217 \mathrm{Zij}$ hebben haren, die neerbuigen als de stengel van de kolzo-kolzo, zij hebben tanden als de kam van kokosbast van Java.

$218 \mathrm{Zij}$ hebben een haarknot, die neerhangt als kralen, hun wenkbrauwen zijn getekend met de flikkering van in de droge tijd neerschietende bliksem.

219 Wat mij aangaat, ik ben er verbaasd over, ik ben verbijsterd, wanneer ik er over nadenk, ik gis er naar zonder het te weten.

$220 \mathrm{Zij}$ weten geen sarong te dragen, in verwarring doen $z i j$ geen rok aan, zij zijn er beduusd en verbijsterd over.

$221 \mathrm{Zij}$ zijn er verbaasd over, zij gissen ernaar zonder het te weten.

$222 \mathrm{Zij}$ hebben geen besef van een kam, $z i j$ weten in het loshangend haar geen scheiding aan te brengen.

$223 \mathrm{Zij}$ worden geholpen door lieden die hun haar kammen, zij worden bijgestaan door lieden, die in hun plaats zacht spreken.

224 Ik ga weer op iets anders over, ik ben weer vervaard, ik ben al rechtdoor ver weggegaan, ik ben al dicht bij, ik ben al tot de helft.

$225 \mathrm{Ik}$ ben al gekomen tot de woeste gronden, de streek zonder geboomte, waar geen huizen zijn opgericht.

226 De zwaluwen slechts verspreiden er zich, de duiven zitten er met elkaar slap neer.

227 De plaats, waar de bos,antilopen op en neer lopen, de wilde zwijnen met al hun kracht steeds bezig zijn.

228 zeer zeker de plaats, waar de herten voedsel zoeken, de plaats waarheen $z i j$ verdwijnen.

229 Ik ga weer op iets anders over, ik ben weer vervaard, ik ben al rechtdoor ver weggegaan, ik ben al dicht bij, ik ben al tot de helft. 
230 Ullambi'mo' tondok 10'bang,

banua to belang-belang, tondok to tang kemuane.

231 To mandai' manna lajan, to umpare-pare songko', to umbilanda sa'benga.

232 To tumannun pori ajak, rumende takinan bembe.

233 Lambanomo', sojanomo', manarru' mambelaomo', rengke'mo', seseanomo'.

234 Ullambi 'mo' bubun misa, turunan sangbua dadi.

235 Bubun natikui tabang, natalimbung danga-danga, naapun lassigi' Daja.

236 Kasirampunan puang, kakendenanna deata, pentuangin-anginanna.

237 Lambanomo', sojanomo', manarru' mambelaomo', rengke'mo', seseanomo'.

238 Ullambi 'mo' rante pondan, ditanete peuean.

239 Dilombok pekalukuan, rante pedambualaran.

240 Ia kinandena puang, ra'dak isinna deata, sakiu'na to menampa.

241 Lambanomo', sojanomo', manarru' mambelaomo', rengke'mo', seseanomo'.

242 Ullambi 'mo' tangdo' Bone, dipetambingi Balanda.

231 mandai' is een nevenvorm van mandasi': naaien. umpare-pare: steeds maar met iets bezig zijn, is het ene klaar, dan beginnen $z i j$ aan het volgende, vgl. parekan.

239 dombu $a{ }^{\prime} a^{\prime}$ is de rozeappel met veel pitjes erin. 
$230 \mathrm{Ik}$ ben al gekomen aan het dorp zonder mensen, de huizen der ongehuwden, het dorp van hen, die geen man hebben.

231 Er zijn lieden in, die steeds maar aan het naaien zijn, de ene muts na de andere aan het maken zijn, de lieden, die korte broeken maken.

232 De lieden, die gordels weven, de pluimen van geitenhaar maken voor de statielans.

$233 \mathrm{Ik}$ ga weer op iets anders over, ik ben weer vervaard, $i k$ ben al rechtdoor ver weggegaan, ik ben al dicht bij, ik ben al tot de helft.

234 Ik ben al gekomen aan de enige bron, de wel uniek van wording.

235 Een bron omringd door Dracaenaplanten, door rode bloemen omgeven, waar drakenbloedplanten van Java omheen staan.

236 De plaats van verzameling der heren, de plaats waarheen de geesten opstijgen, waar zij de koelte zoeken.

237 Ik ga weer op iets anders over, ik ben weer vervaard, $i k$ ben al rechtdoor ver weggegaan, ik ben al dicht bij, ik ben al tot de helft.

238 Ik ben al gekomen tot aan de ananasvlakte, aan de berg, waar men rotan haalt.

239 Het dal, waar men kokosnoten haalt, de vlakte, waar men de wilde djamboe haalt.

240 Het is het voedsel der heren, hetgeen overblijft uit de tanden der goden, de restanten van het voedsel der formeerders.

241 Ik ga weer op iets anders over, ik ben weer vervaard, ik ben al rechtdoor ver weggegaan, ik ben al dicht bij, ik ben al tot de helft.

242 Ik ben al gekomen tot aan de Bonese voorgalerij, waar het Hollandse zijvertrek aan bijgebouwd is. 
243 Dipepalangka leko'i, dipetambing salianni.

244 Tondok boro toda dio, banua mapia toda, loa' pangrantean toda.

245 Tondok pangalloan maa', penge'teran tuda-tuda, ballaran kundai pulo.

246 Budupa-dupamo sae, bu-to-Luwu, to Luwumo, bu-anak-to Sidendenmo.

247 Budupa-dupa rundunna, bukadingi' beluakna.

248 Buboka' ballo ulunna, rampan passimbolonganna.

249 Tiumba'mo sape-sape, dollokmo kundai pangka.

250 Kundai pangka to Bone, sape-sape to Balanda, songko' to ma'palo-palo.

251 Kabuto-buto to lino, tang mana'pa' tau mata.

252 Nakua: "Mambela Bone", nakua: "Langka Balanda".

253 Mambela, mandappi' sia, langka dio sia ren.

254 Sanglebangan sarong sia, sangtengka anak dara sia.

255 Sule diomo' te mai, to tibalik karoenmo'.

256 To pole tangnga bongimo', balik mangka kumandemo'.

247 kading ' ' is een boom met geurige bladeren, welke op die van de kaneelboom lijken. 
243 De verhoogde vloer is er op averechtse wijze in aangebracht, het zijvertrek is er aan de buitenzijde bijgebouwd.

244 Het is zeer zeker een liefelijk dorp, het zijn zeer zeker fraaie huizen, zeer zeker een wijde vlakte.

245 Het dorp, waar de maa'-doeken in de zon gehangen worden, de plaats, waar de oude weefsels uitgespannen worden, waar de pulo-sarongs open gerold worden.

246 Er komt een geur van parfum, de geur van de lieden van Luwu', de lieden van Luwu', de geur van de Sidenden-nakomelingen.

247 De geur van de parfum hunner loshangende haren, de kadingi'-geur hunner haren.

248 De geur van kokosolie van de schoonheid hunner hoofden, hun haarwrong zit goed aaneensluitend op zijn plaats.

249 Het uit bloemfiguren bestaande kantwerk aan het ondereind der rokken vertoont zich, de met haakfiguren versierde sarong komt te voorschijn.

250 De met haakfiguren versierde sarong der Bonieren, het uit bloemfiguren bestaande kantwerk aan het ondereind van de rokken der Hollanders, de hoed van hen, die een stijf gevlochten hoed van bamboe dragen.

251 Leugenachtig zijn de aardbewoners, onbetrouwbaar de mensen.

252 Het heet: "Ver is Bone", het heet: "Op een grote afstand is Holland".

253 Het is ver, maar toch nabij, het is op een afstand, maar toch aanwezig.

254 Het is er even ver vandaan, dat men (in die tijd) de zonnehoed éénmaal kan schuin zetten, éen schrede van een maagd.

255 Ik ben er van teruggekeerd hierheen, $i k$ ben een, die in de namiddag is teruggekeerd.

$256 \mathrm{Ik}$ ben iemand, die te middernacht is teruggekomen, weergekeerd nadat men gegeten heeft. 
257 Sulemo' untiro Bone, ullinde-1inde Balanda, umpesondong Tana Tangnga.

258 Tang kariuanna Bone, tang kapadang-padanganna.

259 Kaluku manna riunna, bua manna siapi'na, pala sirongrean manna.

260 Tondok boro toda dio, banua mapia toda, 1oa' pangrantean toda.

261 Diona' anna dibangun, anna dipatama rinding.

262 Anna sikoko manangnga, anna $1 e^{\prime} k e^{\prime}$ taman telang, diosok petuo tangnga.

263 Banua dibangun 1eko', dipauang ri matallo, dipopemba'ba lu rekke.

264 To dio annan a'ririnna, dio annanda longana.

265 Tang pepori peporinna, tang ue pepangarra'na.

266 Ula' balu peporinna, panakan pepangarra'na, sando peba'na-ba'nanna.

267 Kari' la sa'timo' dio, kari' la sangsule lenmo'.

268 Sapemo sangbilik puang, lolo kulambu deata.

269 Sangtarampak to menampa, sangtondok to palullungan.

257 Volgens de Heer Tammu zou met: "Het Middelland" Bone bedoeld zijn, tussen het Toradja-land en Balanda gelegen. Hij acht het ook moge$1 \mathrm{ijk}$, dat er Midden-Celebes onder verstaan moet worden.

262 manangnga: een middenvak van de wand, dat in twee posten van de wand geschoven wordt.

telang: de lijst van het driehoekige bovenstuk van de voorgevel van het huis. 
257 Ik ben teruggekeerd van het bekijken van Bone, van het aandachtig beschouwen van Holland, van het tot het toppunt gaande bezichtigen van het Middelland.

258 Het niet met gras begroeide van Bone, het niet met grasland bedekte ervan.

259 Het heeft alleen maar kokosnoten als gras, het dicht opeen staande er van zijn slechts arecapalmen, slechts nootmuskaatbomen schieten er welig op.

260 Het is zeer zeker een liefelijk dorp, het zijn zeer zeker fraaie huizen, zeer zeker een wijde vlakte.

$261 \mathrm{Ik}$ was er, toen $\mathrm{zij}$ werden opgericht, toen de wanden er in werden gezet.

262 Toen de middenstukken in elkaar schoven, toen vast ging zitten het inzetten van het driehoekige gevelstuk, de middenstijlen ingezet werden.

263 Het huis werd op averechtse wijze opgezet, het werd naar het Dosten gericht, de deur werd Noordwaarts aangebracht.

264 Er zijn zes stijlen aan, boven zijn er zes overhellende luifels.

265 Geen banden zijn de bindsels er van, niet van rotan hetgeen hen vastbindt.

266 Zwarte slangen zijn de banden er van, panakan-slangen hetgeen hen vastbindt, duizendpoten zijn de diverse versieringen er aan.

267 Bijna was ik daar voor vast gebleven, bijna was ik er in een groep telkens weer naar teruggekeerd.

268 Ik ben al opgenomen in de groep van en in één vertrek met de heren, opgenomen binnen het gordijn van de geesten.

269 op hetzelfde erf met de formeerders, in hetzelfde dorp met hetgeen alles omhult.

petuo is de benaming van drie, soms vier stijlen in het midden van het huis, die opgesteld zijn op de pata', de lengtebalk, die onder het huis loopt; petuo, 1t1. levensdrager; zij dragen de nokbalk van het huis. Bij de petuo worden de offers, die het huis zegen aanbrengen, neergezet.

263 Een huis moet aan de voorzijde naar het Noorden gericht zijn. 
270 Didedekannamo' pindan, dipatalintinganammo' .

271 Angku songlo' dio mai, angku lao sambalin mai, bu'tu lamban dio mai.

272 Lambanmo' rantemo' lian, liling kanan kairimo', katanan beso-besomo'.

273 Tamben kairinna puang, liling kananna deata.

274 Sambalinmo' gaun borrong, di salebu' mean-mean, di tondon batu apian.

275 Batu apian ma'kada, gaun borrong ma'bisara.

276 Ma'bisara kambutu'na, ma'kada kappu arena, sumu tuntun tarunona.

277 Menggereng alomo' rekke, messali'pin banaamo', unnola sa'de langi'mo'.

278 Kuperandan tongan langi', kuola sangpiak tongan, rengke'mo', seseanomo'.

279 Daja silasukna padang, siampello'na daenan, 280 siamma'na randan langi', sodonna ta'pian bombang,

281 ma'kalittua'ma padang, lolong leko'na uai.

282 Uai lolong tumuka', salu sa'dan sule rekke.

283 Sisarangnga' sarambunna, siserek umbanasanna.

277 messali'pin heeft de betekenis van: zich dicht houden aan een wand om niet gezien te worden, aan een helling om niet naar beneden te vallen.

banaa, zie de aantekening bij str. 23. Volgens de Heer Tammu 
270 Er was voor mij het slaan op de borden, er was voor mij het gerinkel der bellen.

271 Opdat ik vandaar zou neerdalen, opdat ik daar vandaan zou weggaan, ik te voorschijn gekomen vandaar naar de overzijde zou gaan.

272 Ik ben reeds over de vlakte naar de overzijde overgestoken, ik ben er van rechts en van links beginnend omheen gegaan, in de beweging van telkens een weinig vooruitgaande.

273 De linkerzijde van de heren kruisend, rondom de rechterzijde van de goden heengaande.

274 Ik ben gekomen aan de overzijde van de gloeiende nevel, bij de flitsende wolk, aan de rand van de in vuur staande rots.

$275 \mathrm{De}$ in vuur staande rots spreekt, de gloeiende nevel voert het woord.

276 Zijn hiel voert het woord, het onderstuk van zijn kin spreekt, het totale aantal van zijn vingers uit zich.

277 Ik ben terzijde Noordwaarts genaderd als een neushoornvogel, ik loop mij dicht houdend aan de rand, zoals de zon (vlak langs het uitspansel gaat), ik ga langs de zijde van het uitspansel.

$278 \mathrm{Ik}$ nader werkelijk tot aan de rand van het uitspansel, ik betreed werkelijk de andere zijde, ik ben al dicht bij, ik ben al tot de helft.

279 In het Noorden, waar de aarde aaneengelast is, waar de landen elkaar opslokken,

280 waar de randen van het uitspansel elkaar inslikken, de opstuwende golven tegenaan botsen,

281 waar het land ondersteboven gekeerd is, en de wateren averechts stromen.

282 De wateren stromen opwaarts, de vloed keert stroomopwaarts terug.

283 Dwars tegen elkaar in stromen de stroomversnellingen, wat met geweld neervalt wendt zich tegen elkaar om.

heeft het woord in dit verband waarschijnlijk de betekenis van "zon".

280 ta'pian bombang, 1t1. het wannen door de golven verricht. 
284 Umbanasa ten karaeng, unnumbuk ten pajo padang, lao ten la'te mamara.

285 Tompokri ulunna salu, tiparitikna uai.

286 Dimengguririkna rompon, ditibantukna uai, di to'dangna bura-bura.

287 Lemo laja' ri ulunna, parragi ri sulunanna, pangden ri rombe ao'na.

288 Lemo laja'na to tumbang, parraginna to malangi', pangdenna to sala padang.

289 Kukalle-kallei aku, pusa'na' umpenajanni, umbarang tang paissanni.

290 To naboko' rokko allo, to tang nakita masiang.

291 Tang nalomban bajo lindo, tang nasaremba to lino, tang naola tau mata.

292 Iapi anna iola, anna ilese ulunna.

293 Deatapi unnolai, puangpi umpolalanni.

294 Umpolalan karoenni, unnola tangnga bongii, umpemangka kumandei.

295 Tang kilambi kami rokko, tang kikaratui kami, tang kienak-enak kami.

296 Sa'ba angin ullambi'i, darinding umpolalanni, angin ungkoko leko'i.

287 rombe ao': als franje neerhangende bladeren van de bamboe aur (Dendrocalamus strictus) aan de ingang van de nederzetting; vroeger werd in de wal, die een nederzetting omgaf, een bamboe aur geplant. 
$284 \mathrm{Zij}$ vallen met geweld neer als waren $\mathrm{zij}$ vorsten, zij zinken neer als waren $z i j$ landsgroten, zij gaan als bliksemschichten in de droge tijd.

285 De bovenloop van de stroom is afgedamd, het water komt er bij druppels uit.

286 Op de plaats, waar het vuilnis ronddrijft, op de plaats van het zich neerstorten van het water, waar het schuim blijft zitten.

287 Er zijn kleine zure citroenen aan zijn oorsprong, grote citroenen in zijn dorpspoort, fijn, geurig gras bij de ingang van het dorp.

288 De kleine zure citroenen van hen, die in bovenaardse toestand verkeren, de grote citroenen van hen, die in vervoering zijn, het fijne, geurige gras van hen, die de grond niet mogen betreden.

289 Wat mij aangaat, ik ben er verbaasd over, ik ben verbijsterd, wanneer ik er over nadenk, ik gis er naar zonder het te weten.

290 Hetgeen door de zon de rug toegekeerd wordt, hetgeen door het licht niet beroerd wordt.

291 Hetgeen waar het schijnsel van het gelaat niet heen komt, hetgeen niet betreden wordt door de aardbewoners, waar de mensen niet langs gaan.

292 Dan pas wordt het betreden, is het, dat de plaats van zijn oorsprong begaan wordt.

293 Het is, dat de goden er langs gaan, de heren het als weg betreden.

$294 \mathrm{Zij}$ bezigen het als weg bij avond, $z i j$ gaan er te middernacht langs, zij doen het pas, wanneer zij klaar zijn met eten.

295 Wat ons aangaat, wij bereiken het niet,

wij komen er niet aan toe, wij komen tot zover niet.

296 Slechts de wind bereikt het, de zachte koelte bezigt het als zijn pad, de wind gaat er op averechtse wijze in een nauwe opening in. 
297 Karua diong anak dara, annan diong tau la'bi'.

298 Pantan unuran bulaan, pantan tingke' rau-rau.

299 Dipata-pata rangka'na, dikaise' tarunona, dipi'to pembaenanna.

300 Dikaise' tang kaise', dipi'to tang danga-danga.

301 Dikaise' rara tau, dipi'to tontian ulu.

302 To sirauk-rauk kila', to silanta' susu landu', sipiring doke deata.

303 Ullambi 'mo' tau pandak, tau sanglampa rangka'na.

304 Sangparajan tarunona, sangpati' pembaenanna.

305 To tang kumande makula', tang rumintok bura-bura.

306 Uran allo nanasui, re'de napa'toran kurin.

307 Manasu nairi' angin, re'de nasimbo darinding.

308 Nasindau talimpuru', nakangkan ma'buan-buan.

309 Kukalle-kallei aku, pusa'na' umpenajanni, umbarang tang paissanni.

310 Umpokarro kaju bajak, umpopesangle tonapa, umposiruk oda-oda.

298 rau-rau, 1t1. hetgeen vermengd is; in d.t. term voor goud, omdat dat meestal met zilver vermengd wordt.

300 en 301 Hier is de eigenlijke betekenis van dikaise' overgegaan in de algemene van: ze worden rood gemaakt. De strofen doelen op lieden, die koppen gesneld hebben.

304 pati': afgehakt stuk. 
297 Er zijn acht jonge meisjes daar, er zijn daar zes voorname lieden.

298 Voor ieder is er een gouden spinnewiel, een werktuig om draden te draaien van goud.

299 Hun vingers worden op elkaar gelegd, hun vingers worden rood gemaakt, hun op en neer wiegen is geweven stof, die in kleurstof is gedompeld.

300 Ze worden rood gemaakt, maar niet met kaise'-vruchten, ze worden in kleurstof gedompeld, maar niet met rode bloemen.

301 Ze worden rood gemaakt met mensenbloed, ze worden gekleurd door koppen, aan een touwtje aan de hand gedragen.

302 Het zijn lieden, die elkaar steken met de bliksem, lieden, die elkaar stoten met een verschietende ster, elkaar werpen met de speren der goden.

303 Ik ben al gekomen bij de heel korte lieden, de lieden, wier vingers éen geleding lang zijn.

304 Wier vingers éen maat lang zijn, wier vingers één knokkel lang zijn bij het zwaaien.

305 Mensen, die geen gekookte spijzen eten, die geen schuim aanraken.

$306 \mathrm{Zij}$ maken het gaar met regen, die in de morgen valt, wanneer het dan aan het zieden is, doen zij het eten in de kookpot.

307 Wanneer het gaar is, waait de wind er over heen, wanneer het aan het zieden is, blaast de koelte er over.

308 Dan draaien de wervelwinden er om heen, $z i j$ houden het in opeenhopingen in de palm van de hand.

309 Wat mij aangaat, ik ben er verbaasd over, ik ben verbijsterd, wanneer ik er over nadenk, ik gis er naar zonder het te weten.

$310 \mathrm{Als}$ groentebakje gebruiken $z i j$ het lemmer van een zwaard, als scheplepel gebruiken $z i j$ een klewang, als lepel gebruiken zij een steekwapen.

305 "schuim" is hier de parallel van "gekookte spijzen" in het eerste lid van deze strofe.

308 nasindau, 1t1. zij knopen het, zij leggen er een knoop in. 
311 Kengku pia-pia langga', kengku tang ponno inaja,

312 la nairi' sallangammo',

la nalisu sarongammo',

la napa'dumba-dumbamo'.

313 Langngan digarunggang langi',

digalugu siu'bean.

314 Dikila' sipemannaan, la'te sitendengan doke.

315 Be'dang mantangmo Sarira, umbuju'mo Taraue, be'dangmo Doke deata.

316 Be'dang mantang siannanan, umbuju' sikaruan.

317 Be'dang pantan bali-bali, karua langngan sibarrung, annan langngan siajoka.

318 Karua kipendemme'i, annan kipa'tulekkenni.

319 Ma'tulekken maja'lotong, sundemme' patora gajang.

320 Patora simundu' langi', darrak sikande batara.

321 Silelean panambunna, siserok umbanasanna.

322 Umbanasa ten karaeng, unnumbuk ten pajo padang, 1 ao ten $1 a^{\prime}$ te mamara.

323 Kueran-eranpa langi', kuso'boipa batara, kurubakpa barre a11o.

315 sarira heeft de betekenis van regenboog; de parallel daarvan is taraue, dat slechts in d.t. gebezigd wordt.

In verband met str. $316 \mathrm{v}$., waar waarschijnlijk gedoeld wordt op het Karua-gebergte in het N.W. van het Rantepaose gelegen, in het landschap Bettuang, zijn de woorden sarira, taraue en doke deata als eigennamen van het rotscomplex Sarira gebezigd, dat zich van uit het landschap Kesu' in Z.0. richting tot in het landschap Sangalla' uitstrekt. 
311 Gesteld ik was een zwak kind, gesteld ik had niet het volle bewustzijn,

312 dan zouden zij mij steeds hoger opgewaaid hebben, zij zouden mij steeds meer en meer rondgedraaid hebben, zij zouden mij steeds meer omgedraaid hebben.

313 Opwaarts zou het uitspansel in de war gebracht zijn, zou het donderslagen hebben doen ontstaan, die aan het rollen zouden zijn.

314 Het zou bliksemslagen hebben doen ontstaan met een geweldig gedreun, bliksems, die met lansen in de hand tegenover elkaar zouden staan.

315 De Sarira blijft bestendig staan, de Regenboogrots verheft zich in al zijn grootte, de Lans der goden blijft bestendig staan.

316 Met hun zessen staan zij er bestendig, met hun achten verheffen zij zich in al hun grootte.

$317 \mathrm{Zij}$ staan er bestendig ieder met zijn partner, acht bij elkaar behorend omhoog rijzend, zes in één verband omhoog rijzend.

318 op acht leggen wij onze hand, op zes steunen wij.

319 Steunend op zwarte maa'-doeken, met de palm van de hand drukkend op de patola gajang-doeken.

320 Patola-doeken, die zich verenigen met het uitspansel, oude doeken, die samenhangen met het firmament.

321 Overal is hun opeenhoping, naar alle zijden is hun neervallen.

$322 \mathrm{Zij}$ vallen met een plof neer als vorsten, zij zinken neer als landsgroten, zij bewegen zich als bliksemflitsen in de droge tijd.

323 Ik ga nog langs een trap ten hemel, ik breek nog door het uitspansel heen, ik dring door de zonnestralen heen.

320 De uitdrukkingen in deze twee parallelle regels willen misschien aanduiden, dat deze doeken uit de bovenwereld naar de aarde zijn neergedaald. 
324 Kuso'boi tang limangku, kurubak tang tarunoku.

325 Kuso'boi 1olo tabang, kurubak tangke lassigi'.

326 Dikurapak danga-danga, di alla' bangkudu api.

327 Karua papa'na langi', pitung todonna batara.

328 Karuapi tang kulambi', annanpi tang kuratui.

329 Tang kubelengan ba'bana, tang kutumbek gualinna, kudedek lumpa-lumpana.

330 Mane lalundun kulambi', mane ongan kuratui.

331 Mane lalundun to tumbang, mane ongan to malangi'.

332 Tangaran to sala padang, pajung to kandeatan.

333 La mulambi'paka, Indo', la mukaratuipaka, la muenak-enakpaka?

334 Daomo ia madona, di ma'gajang-gajanganna, randan tarun-tarunanna.

335 Kabuto-buta to 1ino, tang mana'pa' tau mata.

336 Nakua: "Mambela langi'", nakua: "Langka batara."

337 Mambela, mandappi' sia, langka, dio sia ren.

338 Sanglebangan sarong sia, sangtengka anak dara sia.

327 In de offergebeden en recieten worden vaak twaalf lagen van het uitspansel vermeld, zie The Merok Feast, p. 31, B, str. 73.

333 Met "Moeder" is hier bedoeld de moeder van de to tumbang; de to tumbang vertoeft nu in het uitspansel, maar haar moeder bevindt zich op aarde, in deze wereld. 
324 Niet met mijn hand breek ik er door heen, niet met mijn vingers dring ik er door heen.

325 Ik breek er door heen met een nog opgerold blad van de drakenbloedplant, ik dring er door heen met een tak van de Dracaenaplant.

$326 \mathrm{Bij}$ de vertakking van de rode bloemen, in de vork der takken van de vuur-Morinda-boom.

327 Acht lagen van het uitspansel, zeven verdiepingen van de hemel.

328 De acht nog bereik ik niet, bij de zes nog ben ik niet gekomen.

329 Ik duw het luik er van niet naar boven open, ik stoot niet tegen het deurblad er van aan, ik klop op de deur er van.

330 Toen pas bereikte ik de schuilplaats, toen pas kwam ik bij de beschutting.

331 Toen pas bij de schuilplaats van degene, die in bovenaardse toestand verkeert, toen pas bij de beschutting van degene, die in vervoering is.

332 De overleggingen van hen, die de grond niet mogen betreden, het zonnescherm van hen, die door een geest bezeten zijn.

333 Zult gij ze bereiken, Moeder, zult gij er bij komen, zult gij tot zo ver komen?

334 Hoog is de hoogte er van, in den hoge, waar zij niet zichtbaar zijn, tenzij zij zich bewegen, de rand van het helderblauwe.

335 De aardbewoners zijn leugenachtig, onbetrouwbaar de aardse mensen.

$336 \mathrm{Zij}$ zeggen: "Het uitspansel is ver verwijderd," zij zeggen: "De hemel is op een grote afstand."

337 Het is ver, maar het is toch nabij, het is op een grote afstand, maar het is toch bij ons.

338 Het is er zo ver vandaan dat men in die tijd de zonnehoed éenmaal kan schuin zetten, éen schrede van een maagd. 
339 Sule diomo' te mai, to tibalik karoenmo'.

340 To pole tangnga bongimo', balik mangka kumandemo'.

341 Sulemo' untiro langi', ullinde-linde batara, umpesondong sala padang.

342 Tang kariuanna langi', tang kapadang-padanganna.

343 Andelen manna riunna, bua manna siapi'na, pala sirongrean manna.

344 Tondok boro toda dao, banua mapia toda, loa' pangrantean toda.

345 Daona' anna dibangun, anna dipatama rinding.

346 Anna sikoko manangnga, anna le'ke' taman telang, diosok petuo tangnga.

347 Banua dibangun leko', dipauang ri matallo, dipopemba'ba lu rekke.

348 To dao annan a'ririnna, dao annanda longana.

349 Tang pepori peporinna, tang ue pepamarra'na.

350 Dao bulan peporinna, bintoen pepamarra'na, allo peba'na-ba'nanna.

351 Kari' 1a. sa'timo' dao, kari' la sangsule lenmo',

352 sapemo' sangbilik puang, lako kulambu deata.

353 Sangtarampak to menampa, sangtondok to palullungan.

354 Dipatalintinganammo', angku song1o' dao mai. 
339 Ik ben er reeds van teruggekeerd hierheen, ik ben een, die in de namiddag is teruggekomen.

340 Een, die te middernacht is teruggekeerd, weergekeerd nadat men gegeten heeft.

341 Ik ben teruggekeerd van het bezichtigen van het uitspansel, van het aandachtig beschouwen van de hemel, van het bereiken van het toppunt van het bovenaards gebied.

342 Het uitspansel is niet met gras begroeid, niet met grasland bedekt.

343 Het gras dat er is, is alleen maar welriekend gras, het dicht opeen staande er van zijn slechts arecapalmen, slechts notemuskaatbomen schieten er welig op.

344 Het is beslist een liefelijk oord, de huizen zijn er beslist fraai, de vlakten zijn er beslist wijd.

345 Ik was daarboven, toen $z i j$ werden opgericht, toen de wanden er in werden gezet.

346 Toen de middenstukken in elkaar schoven, toen vast ging zitten dat, waar het driehoekige gevelstuk ingezet werd, de middenstijl ingezet werd.

347 Het huis werd op averechtse wijze opgezet, het werd naar het Oosten gericht, de deur werd Noordwaarts aangebracht.

348 Er zijn zes stijlen aan daarboven, en boven zijn er zes overhangende luifels.

349 Geen banden zijn de bindsels, niet van rotan hetgeen vastbindt.

350 De maan daarboven is zijn bindsel, de sterren hetgeen vastbindt, de zon is zijn versiering er aan in allerlei verscheidenheid.

351 Bijna was ik daar voor vast gebleven, bijna was ik er niet meer van teruggekeerd,

352 was ik afgescheiden in één vertrek met de heer, gegaan naar het gordijn van de god.

353 op hetzelfde erf met de Formeerder, in hetzelfde dorp met hetgeen alles omhult.

354 Er werd voor mij een rinkelend geluid gemaakt, dat ik van boven zou afdalen. 
355 Angku lao sambalin mai, bu'tu lamban dio mai.

356 Lalan tang lalan kuola, tang limbuan kulimbui.

357 Lalan magengge mageang, lalan magumpana lalan.

358 Magengge magiangora', magumpana lalanora', tobangra', tiparanta'ra'.

359 Tibongso' rokkona' limbong, diongna' liku mandalan.

360 La sangsali-sali darrak, la sangpalangka uai, 1a sangsondong bura-bura.

361 Diong karua ulunna, diong annan bali'bi'na, sangpulo pitu ingkokna.

362 Umpokaja-kaja tabang, umposarese lassigi', umpoingkok bura pi'to.

363 Ungkallo-kallona' mamma', ussiangla'na' matindo, untundanna' kalupian.

364 Ke tangnga-tangngai bongi, ke maerunni malillin, ke kapeden-pedenanna.

365 Mata'ka'mo' solo' langngan, bojo' tuka' dao mai.

366 Mata'ka' kasoe-soe, bojo' tang apa nabaa。

367 Tang kan lentekna lumingka, tang kan tuntun tarunona.

368 Landa' isinna lumingka, titodo pa'barusanna, rundunna mallai-1ai. iioohoo! 
355 Dat ik van de overzijde zou weggaan,

ik te voorschijn gekomen vandaar naar de overzijde zou gaan.

356 Ik ging langs een weg, die geen weg was, aan de gewone, gemeenschappelijke weg, nam ik geen deel.

357 Een onrustig stemmende, huivering wekkende weg, de gevaarlijke, slechte der wegen.

358 Ik zou dan wel onrustig, huiverig zijn, een gevaarvolle weg gaan, ik zou best kunnen vallen, ergens op terecht komen.

359 Ik werd naar beneden gelaten naar een waterpoel, ik ben daar in een diepe kolk.

360 Ik zal dan op hetzelfde niveau zijn van het opspuitende, op hetzelfde hoger peil van water, op dezelfde hoger gelegen waterspiegel van het schuim.

361 Daar beneden zijn zijn acht koppen, daar beneden zijn zijn zes vinnen, zijn zeventien staarten.

362 Hij heeft bladeren van de Dracaena als vinnen, hij heeft drakenbloedbladeren als stekels, hij heeft het schuim van het gekleurde tot staart.

$363 \mathrm{Hij}$ stoort mij in de slaap door te wuiven, hij kwelt mij aan alle zijden bij het nederliggen, hij wekt mij, terwijl ik in diepe slaap ben.

364 Wanneer het middernacht is, wanneer het duister aan het afnemen is, wanneer het duister minder geworden is.

365 Ben ik moe van het afdalen, dan gaat hij opwaarts, ben ik afgemat van het opstijgen, dan gaat hij van boven benedenwaarts.

366 Moe loopt zij maar met de armen te slingeren zonder iets bij zich te hebben, afgemat draagt zij niets.

367 Haar benen lopen niet zo flink, haar vingers tasten niet zo goed.

368 De welving van de rij harer tanden is in beweging, de scheiding van haar haar loopt niet door, haar haren zijn steeds aan het fladderen. ohohoho: 
H. van der Veen - 978-90-04-28716-7 Downloaded from Brill.come4/26/2023 02:54:12PM via free access 
De informant, de to minaa Sangaju', deed aan zijn reciet van deze Gelong Maro de volgende inleiding voorafgaan: Wanneer iemand behandeld wordt volgens het maro-ritueel, dan wordt hij (zij) eerst in het huis, waar dit ritueel plaats heeft, gedurende drie dagen gemedicineerd. Voordat men met de behandeling begint, offert men aan de voorouders; dit geschiedt aan de Zuidzijde, d.i. de achterzijde, van het huis. De offerspijs wordt daarbij nog niet op Dracaenabladeren, maar op pisangbladeren neergelegd. Degene, die het offer aanbiedt, is de to minaa. Daarna gaat men naar boven het huis in en nemen de offers aan de goden een aanvang, waarbij van nu af aan de offerspijs op bladeren van de Dracaena terminalis, wordt neergelegd. De offers worden nu door de to ma'dormpi, de medicijnmeester, aangeboden.

Daarna gaat men eten. Na afloop van de maaltijd neemt het zingen van de zang een aanvang.

Deze Gelong Maro vertelt dat de in trance verkerenden relatie hebben met de machten in de rivieren; zij zijn te zamen met hen in bovenaardse toestand (vgl. E Ib str. 53-70). In het bijzonder wordt dan genoemd een kolk in de Salu-rivier (een zijrivier van de Sa'dan), waar een demonische macht huist met acht hoofden, zes vinnen en zeventien staarten, die opjaagt, wanneer men slaapt, onrustig maakt, wanneer men nederligt (vgl. str. 65-67).

De riviermachten worden uitgenodigd naar boven te komen (vgl. str. 70).

De tongkonan, waar men het in deze gelong bedoelde maro-feest viert, wordt omgeven door alle in het voorafgaande genoemde goden (vgl. str. 75v.).

In str. 83-85 wordt de bede uitgesproken, dat het bloed, dat gaat vloeien, tot heil moge strekken, zo ook het snijwapen, dat door de to $m a^{\prime}$ dampi gehanteerd wordt. Daarna geleidt de medicijnmeester de in behandeling zijnde patiënt naar een kleine stellage met een verhoogd vloertje, onder hetwelk een vuurtje wordt aangestoken. 


\section{GELONG MARO SANGAJU'}

1 Mangkamo kumandemo puang, pura iru'mo deata, maimpunmo to menampa.

2 Sorong-sorongammi rangking, poli'mi kandian datu.

3 Sisi'mi landana siruk, sedanni suke irusan.

4 Sarinni bota bulaan, dipakandean manuk.

5 Anna na' sampe membuja, anna mana' marapuan,

6 mabajanan anna bekak, dikki' anna surusiak.

7 Langngan ungkampei lamba', tang umpasombo barana' .

8 Misari ma'laen dadi, senga'-senga' garaganna.

9 Susi manukna Lapandek, londongna Pong Tulangdidi'.

$10 \mathrm{Ma}$ 'kukkua sae tedong, unnoni ratu kanae.

11 Kotok renden pinamile, mengkaro bu'tu bulaan.

1 Meestal wordt To menompa: de Schepper enkelvoudig gebezigd, maar hier als parallel van de heren en de goden kan het beter meervoudig genomen worden volgens de Heer J. Tammu.

Deze woorden hebben betrekking op hèt offer, dat gebracht wordt bij de rite van het massape tabang: de Dracaenabladeren aftrekken, op welke bladeren de offers aan de goden worden neergelegd. Met deze rite neemt het maro-ritueel een aanvang; daarbij wordt een varken geslacht.

De maltijd na het gebrachte offer wordt genoten door de to ma'dompi, de medicijnmeester, de leider van het maro-ritueel. 
1 Reeds hebben de heren gegeten, zijn de goden klaar met drinken, zijn de scheppers ten einde gekomen.

2 Reik het mandje aan, neem de heilige schaal weg.

3 Steek er de doorbuigende lepels in, hang de drinkbekers op.

4 Veeg de sacrale rijstkorrels weg, laat ze aan de kippen te eten gegeven worden.

5 Opdat ze dan voorspoedig gedijen op de stok, van het ene geslacht op het andere een talrijk nageslacht mogen hebben,

$6 \mathrm{zij}$ in een hoop talrijker zijn dan de witte papegaaien, zij meer in aantal zijn dan het gevogelte met veelsoortige geluiden.

7 Mogen zij omhoog gaand de takken van de ficusboom slap doen neerhangen, de waringin aan het gezicht onttrekken.

$8 \mathrm{Elk}$ een heeft een andere gestalte, ieder heeft een andere vorm.

9 Zoals het hoen van Lapandek, de haan van Pong Tulangdidi'.

$10 \mathrm{Hij}$ kraaide, toen kwamen er buffels, hij gaf geluid, toen waren er karbouwen.

11 Hij kakelde, toen trok hij grote buffelstieren voort, hij klauwde de aarde om, toen was er goud.

7 tang umpasombo, 1t1. niet zichtbaar doen zijn.

9 Regel b noemt de haan, die door Pong Tulangdidi' werd geslagen en toen naar het uitspansel vloog en aan de maan hangt, zie H. van der Veen, $V B G, 65$ (1924), 63-70. 
Gelong Unnondo

12 Anna deata i langi', anna puang ri batara.

$13 \mathrm{~Pa}^{\prime}$ tete tabangko mai, ma'lalan lassigi'moko.

14 Inde diong to keengkok, lembangna to kebali'bi'.

$15 \mathrm{~Pa}^{\prime}$ tete tabangko mai, ma'lalan lassigi 'moko.

16 Deata i randan langi', puang ri lelean uran.

$17 \mathrm{Ma}$ 'tete tabangko mai, ma'lalan lassigi'moko, ola taro-taromoko.

18 Anna deata i Bone, anna puang ri Balanda, ma'tete tabangko mai.

19 Titua' tongkamo lembang, tibalintanmo orongan, tibibi'mo koli-koli.

$20 \mathrm{La}$ napolalanko puang, la naolako dewata.

21 Memutu-mutumo Rangri', kumanassakmo Tangdanun, memonganmo Kabongian.

22 La napolalanko puang, la naolako deata,

13 De uitdrukkingen in dit vers wijzen er op, dat de goden worden uitgenodigd het maro-feest bij te wonen. De bladeren van de Dracaena worden bij verschillende verrichtingen van het maro-ritueel gebezigd. Het zijn de planten uit het uitspansel afkomstig.

14 De uitdrukkingen to keengkok en to kebali'bi', 1tl. "degenen, die een staart hebben" en "degenen, die vinnen hebben" geven te kennen de goden van de benedenwereld. De goden van de drie werelden, de bovenwereld, de middenwereld (de aarde) en de benedenwereld, worden tot het offerfeest uitgenodigd.

17 taro-taro is hier vertaald met de vage uitdrukking: "de rode plant", welke uitdrukking de Dracaena te kennen geeft. Volgens de Heer Tammu is de betekenis van taro-taro niet duidelijk; het zou de Dracaena kunnen aanduiden. 
De Gelong, waarbij men hossende bewegingen maakt

12 Goden in het uitspanse1, heren in de hemel.

13 Komt toch langs de Drakenbloedplant hierheen, neemt toch uw weg langs de Dracaena.

$14 \mathrm{Gij}$, die de benedenwereld bewoont, de landstreek van hen, die onder deze aarde huizen.

15 Komt toch langs de Drakenbloedplant hierheen, neemt toch uw weg langs de Dracaena.

16 Goden aan de rand van het uitspansel, heren op de plaats van waar de regen uitgaat.

17 Komt toch langs de Drakenbloedplant hierheen, neemt uw weg langs de Dracaena, betreedt de rode plant.

18 Goden in Bone, heren in Holland, komt toch langs de Drakenbloedplanten hierheen.

19 Van de prauwen is de achtersteven omhoog gewipt en de voorsteven omlaag gezonken, de vaartuigen $z i j n$ reeds omgetuimeld, de schuitjes zijn reeds omgekeerd.

20 wilt gij heren uw weg er langs nemen, wilt gij goden er langs gaan.

21 De Rangri' is aan het dreunen, Tangdanun rommelt, Kabongian weergalmt.

22 wilt gij heren uw weg er langs nemen, wilt gij goden er langs gaan.

21 Tangdanun is gelegen op de helling van het Pedamaran gebergte tussen Tandung in La'bo' en Nanggala. Tangdanun heeft de betekenis van: Braak liggende, woeste grond. Kabongian is een streek op de Pedamaran, ook gelegen tussen Tandung in La'bo' en het landschap Nanggala. Pedamaran heeft de betekenis: Gebied, waar men domar (hars) haalt. 
23 Anna deata i Panga', anna puang ri Sitodo', datu lan di Batupiak.

24 Landosamara i Panga', Lua'toding ri Sitodo', Salombe' ri Batupiak.

25 Ma'baisen rekke Tete, ma'bela rekke Mapaken, tinde daa Kakondongan.

26 Deata umbori' salu, puang umbangnga uai, umpate'dek kalimbuang, unnosok liku mandalan.

27 To mandalan anna liku, to lantuk anna uai, anna mata kalimbuang.

28 Deata daa Mapaken, puang daa Salusumpu, to daa Bombouai.

29 To malute mepatumbang, to pande mepamalangi', meparuntuk sala padang.

30 Deata daa Sesean, puang daa Lindotau, to daa Batumaetan.

23 Panga' en Sitodo' zijn gehuchten behorende tot de kampong Ba'tan (Kesu'). Sitodo' ontleent zijn naam aan een opeenstapeling van rotsblokken. Batupiak is een plaats in Panga', waar een rotsblok ligt, dat gespleten is; de ene helft staat nog overeind, de andere helft ligt neer. De naam betekent: Gespleten Rotsblok.

24 Landosamara, 1t1. (van een buffel gebezigd): die een witte vlek aan de kop heeft en een lang wit uiteinde aan de staart. De naam Salombe' (volledig: kandaure salombe': kralenwerk met lange slierten) heeft de overdrachtelijke betekenis van: roemrucht. Salombe' ri Batupiak is de naam van een god in de vorm van een grote slang, die huist in Batupiak.

25 Tete, Kakondongan, Tetebatu zijn de namen van een plaats in de Sa'dan-rivier bij Tallunglipu, waar grote rotsblokken de rivier afdammen; in die rotsblokken zijn diepe gleuven. Vroeger stak men de rivier over door over die insnijdingen te springen, vandaar de naam Kakondongan (mekkondong $=$ springen). Bij laag water kon men 
23 De god dan van Panga', de heer dan van Sitodo', de geest van Batupiak.

24 De Majestueuze in Panga', de Glorierijke van Sitodo', de Roemruchtige van Batupiak.

$25 \mathrm{Zij}$ hebben vriendschapsbetrekkingen Noordwaarts naar Tete, zij hebben relaties Noordwaarts naar Mapaken, die daar in het Noorden te Kakondongan.

26 Goden, die de grenzen van de rivier bepaalt, heren, die de stromen opent, de bronnen doet opspuiten, de diepe kolken uitgraaft.

27 Degenen, die zich dieper bevinden dan de diepe kolken, die door de stromen heen dringen, en het diepe der bronnen.

$28 \mathrm{God}$ in het Noorden in Mapaken, heer in het Noorden in Salusumpu, degene, die zich bevindt in het Noorden in Bombouai.

$29 \mathrm{Zij}$, die vaardig zijn in bovenaardse toestand te voeren, die bedreven zijn in vervoering te brengen, die doet geraken tot het de grond niet mogen betreden.

30 God in het Noorden op de Sesean, heer in het Noorden in Lindotau, hij, die zich bevindt in het Noorden in Batumaetan.

de rivier oversteken door over die grote stenen te lopen als over een brug, vandaar de naam Tete en Tetebatu (tete: over een brug lopen).

26 umbori' salu, 1tl. de loop van een rivier bepalen, d.i. een geul aanleggen, die allengs, wanneer er steeds water doorloopt, breder wordt en tot een beek wordt.

28 Mapaken is de naam van een heuvel in de kampong Tallunglipu; misschien groeiden daar vroeger veel varens (paken-paken, Gleichenia linearis).

Salusumpu is een andere naam van Bombouai. Salusumpu: "Rivier in de loop gestuit" ontleent zijn naam aan een stroompje dat in de Bombouai ontspringt en verder onderaards doorstroomt. Bombouai: "Watergeest" is de naam van een waterdiertje, dat zich over het watervlak beweegt en goed kan zwemmen. Bombouai is een steeds water gevende bron in het dorp Kalambe' in het landschap Tikala. 
31 Tumba'-tumba' ri Mamullu, dodo' ri Tandiallona, sumolo' ma'dodo riri, lao ma'kundai pusuk, massarembang daun induk, ma'ongan tokeran gandang.

32 Deata dao Mamullu, puang dao Salusule, to dao Tandiallona.

33 Lolok buntu naorongi, tanete nakulea'i, rante natontonan raki'.

34 Umpasongga'-songga' lembang, umpalumalle orongan, umpasassang koli-koli.

35 Anna deata i Napo, anna puang Gandangbatu, to dao kakajuanna, kapangala'-alaranna.

36 Narombe-rombei bolo', natiantenni katirra', nasa'pekki bua ue.

37 Bua ue ri pangala', katirra' ri Salusule, bolo' ri Tandiallona.

31 Regel a en b heb ik als conjectuur uit een andere gezong maro ingevoegd in verband met de volgende vier regels. - tumba' is de titel van de to burake. In het huis van een burake tattiku' (of tattiu') hangt steeds een trom, die geregeld geslagen wordt. De burake tatti $(k) u^{\prime}$ zijn afstammelingen van Buauran en Suloara', de beide to minaa, die volgens de oude overlevering omtrent de ramp wegens bloedschande in Rura, een bua'-feest organiseerden als verzoeningsritueel om weer heil te kunnen verwerven. Deze twee to minaa worden geacht van de Sesean afgedaald te zijn en naar Rura getogen te zijn. Op de Sesean draagt een der stamhuizen de naam Buauran. Omdat de goddelijke machten van de Sesean worden aangeroepen, wordt in de boven vermelde strofen gewag gemaakt van de burake tatti $(k) u^{\prime}$, die zulk een belangrijke functie verrichten bij het bua' kasalle-ritueel. 
31 Edele vrouwen, die de tumba'-titel draagt op de Mamullu, vrouwen van aanzien op de Tandiallona,

zij dalen af, gekleed in gele rokken,

zij zijn getooid met sarongs van de uitgeplozen jonge bladeren van de arenga-palm,

zij zijn gekleed in rokken van de bladeren van de arenga-palm,

zij gebruiken de opgehangen trommels als instrumenten.

32 God op de Mamullu, heer van de Salusule,

hij, die zich bevindt op de Tandiallona.

$33 \mathrm{Zij}$ bevaren de toppen der bergen,

zij steken de bergen over,

zij gaan met vlotten dwars over de vlakte heen.

$34 \mathrm{Zij}$ doen de prauwen schommelend vooruit schieten,

zij laten de vaartuigen vertrekken,

zij doen de schuitjes er doorheen gaan.

35 En de god op de Napo,

de heer van Gandangbatu,

hij, die zich in het bos bevindt, in de woudgebieden.

$36 \mathrm{Zij}$ versieren zich met franjes van bolo'-bladeren, de franjes van de katirra' hangen over hen heen,

zij rukken de vruchten van de rotan af.

37 Rotanvruchten uit het bos, katirra'-vruchten van de Salusule, bolo'-bladeren van de Tandiallona.

Mamullu is de berg aan de Westzijde van het landschap Tikala.

Tandiallona is een berg ten Oosten van de Mamullu; tegen de helling van deze berg is het dorp Pemanikan gelegen.

32 De Salusule, 1tl. "Terugkerende rivier", ontspringt op het Mamullu-gebergte.

35 Napo is de berg tussen de landschappen Dende' en Piongan gelegen, in het Westen van het Rantepaose.

36 katirra': een palm, die op de areca-palm gelijkt; de vruchten dienen wel als ingrediënt bij de betelpruim bij gebrek aan areca-noten. 
38 Deata dao Sopai,

puang dao Tangdirandan,

to dao Tammuanuran.

39 Magaluntu' ke laoi, mariak ke tiallenni, mama' ke menggalugui, ke kumanapa-napai,

40 ke mellao sangrapui, ke ke'de' sangpemanakki, ke ma'baan-baananni.

41 Deata diong Sado'ko', puang diong Sarapiang, to diong kakajuanna, kapangala'-alaranna.

42 Dipotekkenan dokena, dikangkanan penainna.

43 Sikati-kati to Se'ke', sikantuli to Sinadi, sikuan to Sarongbontik.

44 Pataru-taru bingkungna, pasulillin uasena, pasondok pambalaanna.

45 Anna deata i Tampak, anna puang ri Nonongan, datu lan sa'de banua.

46 To dirinding sau' pusuk, to dikulambu pelole', to dilalan-deatai.

38 De Sopai is het gebergte tussen de landschappen Kesu' (complex Nonongan) en Madandan gelegen.

Tangdirandan is een plaats op de Sopai.

Tammuanuran is een andere naam van de Sopai. De naam heeft de betekenis van: De Plaats, waar de regens elkaar ontmoeten.

In tijden van droogte gaat men de Sopai op om daar met een offer om regen te smeken.

40 sangpemanak, 1t1. groep, die van érn en dezelfde moeder afstamt.

41 De Sado'ko' is een gebergte tegen welks hellingen de landschappen Lion, Manimbong en Palesan zich uitstrekken. Sarapian is een streek op de Sado'ko'.

42 Deze strofe berust op de gewoonte dat leden van stand in de oude tijd steeds een volgeling achter zich aan hadden lopen, die hun lans droeg en hun zwaard vasthield. 
38 Goden op de Sopai, heren op Tangdirandan, $z i j$, die zich bevinden op de Tammuanuran.

39 Het romelt, wanneer zij gaan, er is veel gedruis, wanneer er gespannen naar geluisterd wordt, er is veel geraas, wanneer het geknal losbarst, wanneer het dreunt,

40 wanneer $z i j$ in éen groep neerdalen, wanneer $z i j$ in één familieverband vertrekken, wanneer $z i j$ in éen schare bijeen gaan.

41 God beneden aan de Sado'ko', heer beneden bij de Sarapian, hij die zich in het bos bevindt, in de woudgebieden.

42 Hun lansen worden als stokken voor hen gedragen, hun zwaarden worden voor hen in de palm van de hand gedragen.

$43 \mathrm{Zij}$ en de lieden van Se'ke' prikkelen de vechtlust van elkaar, in het voorbijgaan roepen $z i j$ het aan de bewoners van de Sinadi toe, zij zeggen het aan de lieden van Sarongbontik.

$44 \mathrm{Zij}$ maken een oorverdovend lawaai met hun dissels, hun bijlen geven een dreunend geluid, de spaanders er van komen tot aan de dijen.

45 En de god van Tampak, de heer in Nonongan, de hoogedele binnen het dorp.

$46 \mathrm{Zij}$, die Zuidwaarts met de uitgeplozen jonge bladeren van de arenga-palm als met een wand omringd zijn, die met onopengevouwen bladeren van de arenga-palm als met een gordijn omgeven zijn, zij wier weg gemaakt wordt als die der goden.

$43 \mathrm{Se}^{\prime} \mathrm{ke}^{\prime}$ is een streek in het landschap Sanga1la'. De Sinadi is een uitloper van het Latimodjong-gebergte, in het Zuiden van het complex Uluwai van het landschap Sangalla'. Sarongbontik is een berg in het landschap Saluputti gelegen.

Met to Se'ke', to Sinadi, to Sarongbontik, d.i. de bewoners van Se'ke', de Sinadi en Sarongbontik, worden bedoeld de goden die daar huizen.

45 Tampak is een dorp ten Westen van de hoofdplaats Rantepao, aan de overzijde van de Sa'dan-rivier, in het complex Nonongan.

46 Rege1 c wil zeggen, dat die weg omgeven is met een wand van jonge, uitgeplozen bladeren van de arenga-palm. 
47 Anna deata i Gandang, anna puang ri Balenga, datu lan di Tampakpasa'.

48 Landosamara i Gandang, Lua'toding ri Balenga, Salombe' ri Tampakpasa'.

$49 \mathrm{Ma}$ 'tete batumo puang, unnola landa Sarira.

50 Kasirimpunganna puang, kakendenanna dewata, pentuangin-anginanna.

51 Anna deata i Kesu', anna puang ri Bangkudu, datu lan ri Beloara'.

52 Landosamara i Kesu', Lua'toding ri Bangkudu, Salombe' ri Beloara'.

53 Uai limbong ri Kongkang, liku ma'tan ri Malenong, guririk ri Bualajuk.

54 Ma'baisen rokko salu, ma'bela rokko uai, tinde diong Eranbatu.

55 Rokko kibungka' ba'bana, kikilangan gualinna, kidedek lumpa-lumpana.

56 Anna kendek diong mai, anna lao sambalin mai, bu'tu lamban diong mai.

57 Kisolan, kisolan tumbang, kisangajokan malangi', kisangba'teng sala padang.

47 Gandang is een streek tegen het rotscomplex Sarira aangelegen in de kampong Tadongkon.

Tampakpasa': "De aan het Uiteinde gelegen markt" is een andere naam van Po'pong, een stuk open veld tussen de kampongs Tadongkon en Angin-Angin gelegen. Vroeger werd daar markt gehouden.

49 Voor Sarira zie op E Ia, 315. 
47 En de god in Gandang, de heer in Balenga, de doorluchtige in Tampakpasa'.

48 De Majestueuze in Gandang, de Glorierijke in Balenga, de Roemruchtige in Tampakpasa'.

49 De heren betreden de rots, zij gaan langs de boog van de Sarira.

50 De verzamelplaats der heren, de plaats van aankomst der goden, de plaats, waar zij zich verkoelen.

51 En de god van de Kesu', de heer van Bangkudu, de hoogedele in Beloara'.

52 De Majestueuze op de Kesu', De Glorierijke in Bangkudu, de Roemruchtige in Beloara'.

53 Het water van de plas op de Kongkang, het stil stromende diepe water op de Malenong, de draaikolk op Bualajuk.

$54 \mathrm{Zij}$ hebben relatie benedenwaarts met de rivier, $z i j z i j n$ in genegenheid verbonden met het water, deze hier beneden bij Eranbatu.

55 Benedenwaarts gaande openen wij zijn deur, wij tillen zijn luik voor hem op, wij kloppen op zijn poort.

56 Opdat hij van beneden opwaarts stijge, opdat hij van de andere zijde herwaarts kome, overstekend hier verschijne.

$57 \mathrm{Wij}$ zijn tezamen met hem in bovenaardse toestand, wij zijn met hem verenigd in vervoering, wij zijn éen van zin met hem in het de grond niet mogen betreden.

53 Bualajuk is een streek op het gebergte Kesu' gelegen.

54 Eranbatu "Stenen Trap" is een rotspunt aan de linkeroever van de $\mathrm{Sa}^{\prime}$ dan ter hoogte van het dorp Pao in het landschap Kesu'.

57 "wij zijn tezamen met hem in bovenaardse toestand", d.i. met de god van Eranbatu.

kisangajokan, 1t1. wij behoren met hem tot één juk. 
58 Anna deata i Singki', anna puang ri uai, to daja to' Bura-Bura.

59 Ula' kalando i Singki', ula' lajuk ri uai, salombe' to' Bura-Bura.

60 Deata i Lajangtanduk, puang ri Basseanulang, to daja liku mandalan.

61 To mandalan anna $1 \mathrm{iku}$, to lantuk anna uai, anna mata kal imbuang.

62 Anna deata i Batu, anna puang ri Siguntu', datu lan to' Dai-Dai.

63 Mematu-matu api'na, kumanassak balidanna, memongan tintian kala' .

64 Anna deata i Lempe, anna puang ri To' Mala, to dao kakajuanna.

65 Anna deata i Liku, anna puang ri Sarambu, datu lan liku mandalan.

66 Diong karua ulunna, diong annan bali'bi'na, sangpulo pitu ikko'na.

67 Pauru-uru ke mamma', paseangla' ke matindo, parujang ke kalupian.

58 Singki' is de rots aan de overzijde van de Sa'dan tegenover de hoofdplaats Rantepao.

To' Bura-Bura: "De Plek van het Schuimende" is de andere naam van de Singki'; de Sa'dan gaat in een bocht om de Singki' heen, zodat haar water gaat schuimen.

61 lantuk: recht op afkomen, direct komen.

62 Batu en Siguntu' zijn twee plaatsen in het dorp Kadundung (complex Nonongan van het landschap Kesu'), waar de tongkonan (voorouderhuizen) met die beide namen staan.

Dai-Dai is een andere naam voor de plek Siguntu' in het dorp Kadundung. 
58 En de god van de Singki', de heer in de rivier, hij, die in het Noorden is op de plek van Bura-Bura.

59 De lange slang van de Singki', de grote slang in de rivier, de doorluchtige op de plek van Bura-Bura.

60 De god in Lajangtanduk, de heer in Basseanulang, hij in het Noorden, waar de diepe kolk is.

$61 \mathrm{Hij}$ die dieper is dan een kolk, die een diepere doorvaart heeft dan een rivier, dan een steeds vloeiende bron.

62 En de god van Batu, de heer van Siguntu', de hoogedele op de plek van Dai-Dai.

63 De stukken hout, waarin het weefsel geklemd is, dreunen steeds, de weeflat bonst, het schering-latje kleppert.

64 En de god in Lempe, de heer in To' Mala, hij, die woont in het geboomte.

65 En de god in Liku, de heer in Sarambu, de hoogedele in de diepe kolk.

66 Daar beneden zijn acht koppen, beneden zijn zes vinnen, zijn zeventien staarten.

$67 \mathrm{Hij}$ jaagt op, wanneer men slaapt, hij maakt onrustig, wanneer men nederligt, hij schudt wakker, wanneer men in diepe slaap is gevallen.

63 De tintian (van tinti "opheffen") is een latje waaraan de scheringdraden (kala') op zo'n manier bevestigd zijn dat, als het omhoog wordt geheven, de boven-scheringdraden mee omhoog gaan.

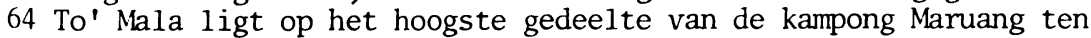
Noorden van de Buntususu (in het bij str. 62 genoemde complex). Lempe ligt ten Westen daarvan.

65 Sarambu is een waterval in de rivier de Salu ter hoogte van de kampong Sangpolobungin. Liku is een kolk onder aan die waterval. 
68 Ke tangnga-tangngai bongi, ke maerunni malillin, ke kapeden-pedenanni.

69 Anna deata i Tina', anna puang ri Lebusan, datu lan ri Tetebatu.

70 Pembaliang saritako, pembibi' seko manikko, kenden tali to Batuko.

$71 \mathrm{Ma}$ 'baisen rekke Kabu', ma'bela rekke Masuru, tinde daa Limbonga1lo.

72 To malute mepatumbang, to pande mepamalangi', meparuntuk sala padang.

73 Anna deata i Sarre, anna puang ri Ba'baalang, datu lan liku mandalan.

74 To matindo lan parungna, to mamma' lan kulambunna, lajan pandung bulajanna.

75 La rampo inde te tondok, kenden inde te pangleon.

76 Nabalassa'mo te tondok, nabuju'mo te pangleon, te lajan sa'de banua.

69 Lebusan en Tetebatu zijn andere namen van het gehucht Tina' in de kampong Sangpolobungin. Tetebatu, vgl. aantekening bij str. 25.

70 Pembaliang saritako, 1t1. keert om op de wijze van een sarita-doek; sarita is een lang, smal, blauw weefsel met witte figuren erin. pembibi' seko manikko, $1 \mathrm{t} 1$. wendt $\mathrm{u}$ om op de wijze van kralenwerk, dat de vorm heeft van een hoekvormige figuur, zoals de passekong in het kandaure-kralenwerk.

71 In dit vers slaat "zij" op de in trance verkerenden. Kabu', Masuru en Limbongallo zijn de namen van een plek in de Salu-rivier ten Oosten van de kampong Kalindungan. De eigenlijke naam is Kabu', maar deze plek wordt ook Limbongallo genoemd naar een demonische figuur, die in de volksmond ook Indo' Orron heet; orron heeft de betekenis van: een dof geluid. Deze Indo' Orron geeft het geluid van een loeiende buffel; zij kan de gedaante van een hond of een varken aannemen en doodt mensen op een wrede manier; vandaar dat die plek ook Masuru heet: de Wrede. 
68 Wanneer het midden in de nacht is, wanneer de duisternis gaat afnemen, wanneer het geheel stil is.

69 En de god in Tina', de heer in Lebusan, de hoogedele in Tetebatu.

70 Keert op edele wijze om, wendt $u$ op majestueuze wijze om, komt gij naar boven, op de wijze van de hoofddoeken van Batu.

$71 \mathrm{Zij}$ hebben relatie stroomopwaarts met Kabu', zij zijn in genegenheid verbonden stroomopwaarts met Masuru, die hier in het Noorden in Limbongallo.

$72 \mathrm{Hij}$ die vaardig is in bovenaardse toestand te voeren, die bekwaam is in vervoering te brengen, die doet geraken tot het de grond niet mogen betreden.

73 En de god in Sarre, de heer in Ba'baalang, de hoogedele in de diepe kolk.

$74 \mathrm{Zij}$ die neerliggen in hun omheining, die slapen binnen hun gordijn, binnen hun gewijde slaapplaats.

$75 \mathrm{Zij}$ zullen hier in dit dorp aankomen, zij zullen opstijgen naar dit gehucht.

$76 \mathrm{zij}$ omgeven dit dorp met $z$ 'n allen, $z i j$ brengen dit gehucht in opschudding, hier binnen deze nederzetting.

$73 \mathrm{Ba}$ 'baalang is een diepe plaats in de rivier; daar ligt een grote steen op enige kleinere stenen, waardoor een nauwe opening is ontstaan, waar het water doorheen stroomt; vandaar de naam: "Deurtje van de Rijstschuur", want die opening heeft de grootte van het kleine deurtje van de rijstschuur.

De uitnodiging aan de goden eindigt bij Ba'baalang; het is een sacrale plaats ten Zuiden van de kampong Sarre, in het complex Salu (landschap Kesu'). - Het maro-ritueel, waarbij de hier meegedeelde gelong gezongen wordt, kan in en bij een der tongkonan in Salu gevierd worden.

74 Deze strofe beschrijft de verblijfplaats van de goden die huizen in Sarre, Ba'baalang en in de diepe kolk vermeld in str. 73.

76 "met z'n allen", d.i. alle aangeroepen goden, vanaf de goden in het uitspansel tot en met de god die in Ba'baalang huist. De plek van het maro-feest bij een der tongkonan in Salu wordt dan omringd door al de aangeroepen goden. 
77 Make' millikmoko mai, make' palimbangunmoko.

78 Kisolan, kisolan tumbang, kisangajokan malangi', kisangtende' sala padang.

79 Untadoikan tang balle, umbenkan tang kira-kira.

80 Balle tau, tang ballekan, leaga, tang leagakan, lembe, tang lembe-lembekan.

81 Angki ma'dampi ma'burra, angki ma'pakuli-kuli, angki ma'pasilosongan,

82 lako to naujak puang, to nalumpisu deata, to natendeng to menampa.

$83 \mathrm{Ta}$ 'pa passakkeko rara, ra'pak-ra'pakko malea, darindingko rara tau.

84 Iate piso kutoe, mataran lan di limangku, bajak tuntun tarunoku.

85 Ta'pa passakkeko piso, darindingko oda-oda.

86 Padukku lalongmi api, patibarrangmi ruaja, kangkanmi ma'lana-lana.

81 ma'pasilosongan, 1tl. het uiteinde van één van twee voorwerpen verbinden met het uiteinde van het andere, zó dat het éne uiteinde het andere overlapt. 
77 Maar gij, verheft $u$ hierheen, maar gij, staat nu op.

78 Wij zijn tezamen met hen in bovenaardse toestand, wij zijn met hen verenigd in vervoering, wij zijn in evenwicht met hen in het de grond niet mogen betreden.

$79 \mathrm{Zij}$ reiken het ons aan, die niet in de war zijn, $z i j$ geven het ons, die geen streken hebben.

$80 \mathrm{zijn}$ er die in de war zijn, wij zijn niet in de war, zijn er die beteuterd zijn, wij zijn niet beteuterd, zijn er die verbijsterd zijn, wij zijn niet verbijsterd.

81 Opdat wij met medicijn behandelen, geneeskrachtig bespuwend, opdat wij cureren, opdat wij zonder enig mankement de genezing tot stand brengen,

82 bij hen, die door elkaar geschud worden door de heren, die door de goden aan het rondtollen gebracht worden, die door de formeerders geprezen worden.

83 Bloed, moogt gij terstond tot heil zijn, het rode, moogt gij tot genezing zijn, mensenbloed, moogt gij heilzaam zijn.

84 Dit mes houd ik vast, het scherpe is in mijn hand, zwaard, zoek mijn vingers.

85 Wees terstond heilzaam, mes, wees genezend, snijwapen.

86 Steek het vuur flink aan, doe de sintels gloeien, houd het opvlammende in de hand. 
H. van der Veen - 978-90-04-28716-7 Downloaded from Brill.come4/26/2023 02:54:12PM via free access 


\section{GELONG MASSINGGI' (E II)}

\section{Inleiding}

Nadat de Gelong Maro ten einde is gezongen, gaat men over tot het ma'pakande (1tl. spijzigen), het uitreiken van de kippen, dic bijeengebracht zijn. Deze worden toegewezen aan de functionarissen op het feest en de notabelen in de adatgemeenschap.

Daarna wordt de Gelong Massinggi' aangeheven. Massinggi' heeft de betekenis van: lofprijzingen uitspreken. Dit geschiedt op het marofeest en op de grote feestdag van het la'pa' kasalle-feest. De lofprijzingen gelden in het algemeen de aanzienlijke, machtige en rijke lieden in de adatgemeenschap, in het bijzonder de leden van de familie, die het maro-feest aanricht, en dienen om hun levensloop te vermelden, hun waardigheden, hun dapperheid enz. Wanneer er onder die familic zijn, die een sneltocht hebben verricht, dan wordt ook daarvan gewag gemaakt.

Deze tekst werd meegedeeld door de to minaa Sangaju'. 
Tekst

1 La kuparekkemo mati',

la kusande simisa',

la kukanoto-notoko.

2 Patarimako bajumm,

balla'ko lindo piomu, la kuparokkoi singgi'.

3 Te daja kakojan balo, bendo' sirisso isinna.

4 Denka buntu tang natendeng, tanete tang naloloan, lombok tang nasiri-siri.

5 Anna malutura sa'dan, anna borrongra uai.

6 Otonan dokena lalong, pessimbonganna buaja.

7 Kaluku natuang lamban, pangi natonti unnorong.

8 Tikadedek bainena, melale' sangbanuanna.

9 Napa'parampoi sae, napa 'baen-baenanni.

10 Ao' kumpang tama tondok, ao' kakumbaa'-baa'.

3 kakojan: riviermonster op een krokodil gelijkend (?); kakojan balo, 1tl. gestreepte kiekendief, heeft een hevige vervloekingskracht volgens de Heer Tammu.

bendo': riviermonster als een krokodil. bendo' sirisso isinna, 1 t1. tandenknarsend riviermonster.

4 nasiri-siri, 1tl. zij schudden het heen en weer, zij wannen het, zij wiegen het heen en weer.

Deze gehele strofe geeft te kennen, dat alle aanzienlijke, machtige heldhaftige lieden in de adatgemeenschap geroemd worden. Volgens de Heer Tammu zijn deze lofprijzingen een satyrieke aanmoediging, waarbij men juichkreten aanheft, met de lans zwaait om tot de krijg aan te vuren. 
Vertaling

1 Laat ik het $\mathrm{u}$ Noordwaarts toereiken, laat ik het juiste voor ieder uwer bepalen, laat $i k$ het voor $u$ telkens mogen treffen.

2 Maak uw baadje voor de ontvangst gereed, rol het uiteinde van uw lendengordel open, dat ik de lofprijzing er in doe neerkomen.

3 Deze genadeloze geweldenaars hier in het Noorden, deze tandenknarsende aanvallers.

4 Is er een berg, die hen niet prijst, een gebergte, dat hen niet looft met gezang, een dal, dat hen niet verheft met het zwaaien van de handen?

5 Hoe is het, dat de vloed troebel is, dat het water rood is?

6 Het is het indompelen van de lans van de heldhaftige, het is de plaats, waar de krokodillen in het water spelen.

$7 \mathrm{Zij}$ nemen bij het oversteken kokosnoten mee, bij het zwemmen houden zij pangi-vruchten aan een touwtje vast.

8 De heldere lach van hun vrouwen klinkt op, hun buurtgenoten lachen luide.

9 Aankomend brengen zij die aan hen, zij laten ze heen en weer zwaaien.

10 De overhellende dikke bamboe gaat het dorp in, de dikke bamboe wiegelt zacht heen en weer.

$5 v v$. wijzen op de bijzondere lofverheffing, die degenen, die in de strijd een vijand gedood en zijn kop gesneld hadden, ten deel viel, zie ook The Chant, p. $76, \mathrm{R} 2$, str. 13 .

7 pangi, de Latijnse naam luidt: Pangium edule. De hier genoemde kokosnoten en de aan een touwtje gedragen vruchten van Pangium edule, duiden op de gesnelde koppen, die de genadeloze geweldenaars meenemen naar het dorp.

$10 a o^{\prime}$ is de Dendrocalamus strictus. 
11 Ia natete lumumpa', ungkasolang to ma'lambuk, barra' sikaponak rara.

12 Tang umpopellolo induk, tang umpopentaruk tallang.

13 Nasembang napobala'ba', naala napa'pararukki.

14 Nadandanan rekke annan, nabato' rekke karua.

15 Be'dang pantan bali-bali, napobaine tabuan, napoka'din simaduan.

13 pa'pararukan = surasan tallang: offerstelletje uit 4 bamboestijlen bestaande; in het bovenste gedeelte van die stijlen zijn figuren gesneden; aan de bovenzijde en aan de benedenzijde van die stijlen bevindt zich een vloertje; dat offerstelletje wordt gebezigd bij de offerplechtigheid van het manganta'-ritueel.

15 De regels b en c duiden aan, dat de schedels van de door de vurige strijders verslagenen, die aan de voorgevel van het huis van die strijders worden opgehangen, gebruikt worden als de plaats, waar de wespen hun nesten maken. 
$11 \mathrm{Zij}$ gaan er op af, er op af dringend,

$z i j$ brengen ongemak over de rijst stampenden, de gestampte rijst vermengt zich met bloed.

$12 \mathrm{Zij}$ laten de suikerpalm niet uitspruiten, zij laten de bamboe geen scheuten krijgen.

$13 \mathrm{Zij}$ hakken hem om en vlechten de bladnerven gekronkeld ineen, zij halen hem en bezigen hem als offerstelletje op vier bamboestijlen.

$14 \mathrm{Zij}$ stellen ze Noordwaarts in een rij van zes op, $z i j$ ordenen ze Noordwaarts in een rij van acht.

$15 \mathrm{Zij}$ staan er ieder tegenover zijn partner, de wespen zijn er mee getrouwd, de wespen met een dun middellijf hebben hen als hun verloofden. 
H. van der Veen - 978-90-04-28716-7 Downloaded from Brill.come4/26/2023 02:54:12PM via free access 


\section{SINGGI' GELONG TALLANG (E III)}

\section{Inleiding}

Deze gelong, "de lofprijzing de bamboe bezingende" wordt gezongen op een groot maro-feest gedurende de nacht voorafgaande aan het opstellen van de bate (zie E IV). De volgende morgen gaat men de bamboe, die als bate zal dienst doen, kappen.

Deze bamboe wordt in de gelong als sacraal beschreven, neergedaald uit de bovenwereld, str. 4-6.

Men heft deze zang aan nadat men de gelong massinggi' heeft gezongen. 
Tekst

1 La kulambi 'moko tallang,

la kukaratuimoko.

2 Tallang e, mussallaona', mudoko-dokoiona', muparamban buluona'.

3 Angku dido'domo tumbang, angku dipakaolemo, lele tang ditonganammo'.

4 Tallang tumumbo i langi', umbalumbun ri batara, to'dang lan lindona bulan.

5 Tallang tang natanan tau, tang napatumbo to lino, tang naosok tau mata.

6 Tallang pantananna puang, pa'parorakna dewata, pa'parumaka-makanna.

7 Mennuaka' doti langi', membola patola gajang.

8 Tallang ma'buku bulaan, mengkalopak kiding-kiding.

9 Tisea' tinggi lapana, mendaun seleng sirenden, merranga' patola gajang.

10 Karua langngan sibarrung, annan langngan siajoka, be'dang pantan bali-bali.

1 tallang is een wat dunnere bamboesoort dan de bamboe betung. De hier bezongen tallang is de bamboe voor de bate, een bamboestaak, aan welke een rode doek wordt bevestigd, die bij de slotrite van het maro-feest in optocht naar de feestplaats gedragen wordt.

6 rorak en rumaka hebben de betekenis van: zich naar alle zijden uitbreiden; pa'parorakna dewata = pa'parumaka-makanna dewata: hetgeen de god zich naar alle zijden doet uitbreiden.

7 doti langi' is een maa'-doek met een kruisfiguur; patola is een Javaans woord, dat waarschijnlijk via het Boeginees zijn weg gevonden heeft in de Toradjalanden; in het Boeginees heeft het de betekenis van: soort zijden stof.

10 siajoka, 1tl. met elkaar een juk vormend. 
Vertaling

1 Ik wil nu tot $\mathrm{u}$, bamboe, komen, ik wil nu tot u geraken.

2 He bamboe, gij weerhoudt mij, gij doet mij steeds maar mager worden, gij doet mij de haren te berge rijzen.

3 Zodat ik in bovenaardse toestand zijnde beschimpt word, zodat ik verwijten krijg, men mij overal in het rond niet erkent.

4 Dc bamboe was uitgestoeld in het uitspansel, was hoog opgewassen in het firmament, was gezeten in het gelaat van de maan.

5 De bamboe is niet door mensen geplant, niet door lieden van deze aarde gepoot, niet door mensen van vlees en bloed in de grond gezet.

6 Bamboe was het door de heer geplante, dat, wat de god zich overal heen deed uitbreiden, dat, wat hij overal heen deed uitstoelen.

7 Ze had wortels luisterrijk als de doti langi'-doek, ze had uitspruitsels edel als het kostbare oude weefsel met een edele kruisfiguur.

8 De bamboe had gouden knopen, de lagen van haar bast waren als schitterende stukjes goud van een vrouwensieraad.

9 De haartjes er van waren verspreid als donkerrode kralen, ze had bladeren die zijn als op elkaar volgende seleng-doeken, ze had twijgjes edel als het kostbare oude weefsel met een gouden kruisfiguur.

10 Acht gingen in paren omhoog, zes gingen twee aan twee omhoog, zij verhieven zich ieder met zijn partner. 
11 Kasalle nairi' angin, 1obo' nasimbo darinding, napaeran talimpuru', nasenggong $1 a^{\prime}$ te mamara.

12 Nabongsoran daa mai, naulo' sambali' mai, bu'tu lamban diong mai.

13 Dao pangrantena puang, kala'paranna deata.

14 Umpilei ma'lombokna, untiro tikallebona, to tipara'da-ra'danna.

15 Nanai longke ditanan, tambulebu' diosokan, tumajang ditanan misa.

16 Tallang tang natanan tau, tang napatumbo to lino, tang naosok tau mata.

17 Tallang pantananna puang, pa'parorakna dewata, pa'parumaka-makanna.

18 Nabongsoran daa mai, naulo' sambalin mai, bu'tu lamban diong mai.

19 To dao to' tabang tua, nanai longke i tanan, tambulebu' diosokan, tumajang ditanan misa.

20 Mennuaka' doti langi', membola patola gaang.

21 Tallang ma'buku bulaan, mengkalopak kiding-kiding.

12 'Hij" zal in verband met str. 17 doelen op de god, men kan echter hier en in verschillende van de volgende strofen ook vertalen met "zij", d.w.z. de goden.

15 Het woord tambulebu' is ons niet duidelijk; vanwege de betekenis van het woord Zebu': "omvatten" wilde de Heer Tammu het verklaren met: die breed uitstoelt. 
$11 \mathrm{Zij}$ werden groot, terwijl de wind er over heen woei, zij groeiden weelderig, terwijl het koeltje er langs streek, de storm hen heen en weer zwaaide, de bliksemschichten in de droge tijd hen deden schudden.

$12 \mathrm{Hij}$ deed haar van het bovengebied neerkomen, hij liet haar naar beneden gaan van de overzijde, zij verscheen overgekomen daar vandaan.

13 op het plein van de heer, op de plaats van het afsluitingsfeest voor de god.

$14 \mathrm{Ze}$ koos uit hetgeen de vorm heeft van een dal, ze zag om naar hetgeen hellend is, een plek die vlak is.

15 op een plaats waar zij goed te zien was, werd ze geplant, werd de wijd-gestoelde in de grond gezet, als de hoogste werd zij apart geplant.

16 De bamboe is niet door mensen geplant, niet door lieden van deze aarde gepoot, niet door mensen van vlees en bloed in de grond gezet.

17 De bamboe was het door de heer geplante, dat, wat de god zich overal heen deed uitbreiden, dat, wat hij overal heen deed uitstoelen.

$18 \mathrm{Hij}$ deed haar van het bovengebied neerkomen, hij liet haar naar beneden gaan van de overzijde, ze verscheen overgekomen daar vandaan.

$19 \mathrm{Zij}$ is daar boven op de plaats van de oude Dracaena-plant, op de plaats, waar zij goed te zien is, werd ze geplant, werd de wijd-gestoelde in de grond gezet, als de hoogste werd zij apart geplant.

$20 \mathrm{Ze}$ had wortels luisterrijk als de doti Zangi'-doek, ze had uitspruitsels edel als het kostbare oude weefsel met een edele kruisfiguur.

21 De bamboe had gouden knopen, de lagen van haar bast waren als schitterende stukjes goud van een vrouwensieraad. 
22 Tisea' tinggi lapana, merranga' ta'bi bulaan, mendaun seleng sirenden.

23 Nabongsoran daa mai, naulo' sambali' mai.

24 Bungka'ko ba'bana langi', pentiroanna deata.

25 La napolalanko tallang, la naolako totiang.

26 Sikaloli' tabang borrong, sibaja lassigi' daja, to inde tallu lolona.

27 Tindak sarira naola, mian kila' napolalan, sundallak napolambanan.

28 Sae mengkanna i Pongko', mentunanna' i Lebukan.

29 Tallang tumombo i Pongko', umbalumbun ri Lebukan.

30 Nabongsoran laan mai, naulo' sambali' mai, bu'tu lamban diong mai.

31 Sae mengkanna i Sepang, mentunanna' ri Karangan.

32 Tallang tumombo i Sepang, umbalumbun ri Karangan.

33 Nabongsoran diong mai, naulo' sambalin mai, bu'tu lamban diong mai.

34 Sae mengkanna i Rura, mentunanna' ri Lellua.

35 Tallang tumombo i Rura, umbalumbun ri Lellua.

36 Nabongsoran diong mai, naulo' sambalin mai.

26 De offerande wordt bij het maro-ritueel op Dracaenabladeren neergelegd.

31 Sepang is gelegen aan de uitmonding van de Sa'dan-rivier; Karangan ligt in de nabijheid daarvan. 
22 De haartjes er van waren verspreid als donkerrode kralen, ze had twijgjes als gouden bloesems, ze had bladeren als op elkaar volgende seleng-doeken.

$23 \mathrm{Hij}$ deed haar van het bovengebied neerkomen, hij liet haar naar beneden gaan van de overzijde.

24 Open gij de poort van het uitspansel, het venster der goden.

25 Dat de bamboe haar weg langs u neme, de jonge bamboetwijgen $u$ betreden.

26 Tezamen met de donkerrode drakenbloedbladeren, vergezeld van de Dracaenaplant van het bovengebied, zij hier, die drie jonge nog opgerolde bladeren heeft.

27 Ze gingen langs de regenboog, ze namen hun weg over de bliksemflitsen, ze trokken over het vonkelende heen.

28 Ze betraden Pongko', ze verhieven zich op Lebukan.

29 De bamboe wies op op Pongko', ze schoot welig op op Lebukan.

$30 \mathrm{Hij}$ deed haar van daar uit neerkomen, hij liet haar naar beneden gaan van de overzijde, ze verscheen overgekomen daar vandaan.

31 Ze kwam in Sepang, ze verbleef in Karangan.

32 De bamboe groeide in Sepang, ze schoot welig op in Karangan.

$33 \mathrm{Hij}$ deed haar van daar uit neerkomen, hij liet haar naar beneden gaan van de overzijde, ze verscheen overgekomen daar vandaan.

34 Ze kwam in Rura, ze verbleef in Lellua.

35 De bamboe groeide in Rura, ze schoot welig op in Lellua.

$36 \mathrm{Hij}$ deed haar van daar uit neerkomen, hij liet haar naar beneden gaan van de overzijde.

34 Rura is de naam van een vlakte tussen Enrekang en Kalosi. Daar werd bloedschande bedreven door de kinderen van Londongdilangi' . De plaats, waar het huwelijksritueel plaats vond, verzonk in de grond, zie The Chant, p. $25 \mathrm{v}$., aantekening bij str. 71. 
37 Sae mengkanna i Se'ke', mentunanna ri Sinadi.

38 Ia kumpang langngan Bone, ia kakumbaa'-baa'.

39 Iamo mendadi ringgi', ia kombong tali-tali.

40 Umpasanda Lepong bulan, angganna Matari' alo.

41 Ia kumpang tana Daa, ia kakumbaa'-baa'.

42 Iamo mendadi sampin, ia kombong ri pennammu'.

43 Ia kumpang ri Palopo, ia kakumbaa'-baa'.

44 Iamo mendadi sia, ia kombong lepa'-lepa'.

45 Ia kumpang ri To' Dambu, ia kakumbaa'-baa'.

46 Iamo mendadi bassi, ia kombong ri mataran.

47 Umpasanda Lepong bulan, angganna Matari' allo.

48 Ia kumpang rekke Sa'dan, ia kakumbaa'-baa'.

49 Iamo mendadi ta'dung, ia kombong ongan-ongan.

50 Napoamba ke malei, sumpakna ke tiallenni.

$39,42,44,46,49$ hebben de betekenis, dat uit de verkoop van deze bamboe rijksdaalders, kwartjes, weefsels, kleding, zout, ijzer, zwaarden verkregen worden.

40 Lepong Bulan, volledig Basse Lepongan bulan: het Bondgenootschap, dat een kring vormt, schijfvormig als de maan; het was het gebied van het Bondgenootschap, dat alle landschappen omvatte, die zich hadden aangesloten om de opdringende macht van Bone te weerstaan ten tijde van de vorst Arung Palakka. De parallelle uitdrukking hiervan is: Matari' allo: cirkelvorming als de Zon.

42 penomm', $1 t 1$. bedekking.

44 Zepa'-Zepa', 1tl. waaraan men likt om te proeven of het zout is. 46 mataran, 1 ti. het scherpe. 
37 Ze kwam in Se'ke', ze verbleef op de Sinadi.

38 Ze boog over opwaarts naar Bone, ze wiegelde zacht heen en weer.

39 Ze leverde rijksdaalders op, uit haar ontstonden kwartjes.

40 Ze strekte zich uit over de hele Kring, schijfvormig als de maan van het Bondgenootschap, tot en met de laatste toe van de Kring, cirkelvormig als de zon.

$41 \mathrm{Ze}$ boog neer tot Java, ze wiegelde zacht heen en weer.

42 Uit haar ontstonden weefsels, uit haar kwam kleding voort.

43 Ze boog neer naar Palopo, ze wiegelde zacht heen en weer.

44 Ze leverde zout op, ze had het ziltige tot resultaat.

45 Ze boog neer naar To' Djambu, ze wiegelde zacht heen en weer.

46 Ze leverde ijzer op, ze had zwaarden tot resultaat.

47 Ze strekte zich uit over de hele Kring, schijfvormig als de maan van het Bondgenootschap, tot en met de laatste toe van de Kring, cirkelvormig als de zon.

$48 \mathrm{Ze}$ boog neer tot Sa'dan, ze wiegelde zacht heen en weer.

$49 \mathrm{Ze}$ werd tot een zonnescherm, uit haar ontstond een voorwerp tot beschaduwing.

50 Men doet gemaakt en druk er mee bij het gaan, wanneer men neerzit heeft men haar als bijbehorend attribuut bij zich.

$48 \mathrm{Sa}$ 'dan is een landschap in het Noorden van Tana Toradja, aan de bovenloop van de Sa'dan-rivier, grenzend aan haar bronnengebied. 50 "men doet gemaakt en druk er mee", d.i. met de in 49 genoemde pajoeng. sumpakna, 1t1. het er aan toegevoegde, het aanhangsel er van, het er bij behorende. 
51 Ia kumpang rekke A'kung, ia kakumbaa'-baa'.

52 Iamo mendadi manuk, ia kombong kio'-kio'.

53 Ia kumpang ri Sesean, ia kakumbaa'-baa'.

54 Iamo mendadi baka, ia kombong kolong-kolong.

55 Ia kumpang langngan Lempo, ia kakumbaa'-baa'.

56 I amo mendadi sarong, ia kombong ongan-ongan.

57 Ia kumpang rekke Ta'ba', ia kakumbaa'-baa'.

58 I amo mendadi ue, ia kombong ri pangarru'.

59 Ia kumpang ri Pangala', ia kakumbaa'-baa'.

60 Iamo mendadi kaa, ia kombong tanak-tanak.

61 Ia kumpang ri Baruppu', ia kakumbaa'-baa'.

62 Iamo mendadi ipo, ia kombong suppi'-suppi' .

63 Ia kumpang ri Belau, ia kakumbaa'-baa'.

64 Iamo mendadi ria, ia kombong amung-amung.

65 Ia kumpang lako Tabang, ia kakumbaa'-baa'.

$51 \mathrm{~A}$ 'kung is een dorp tegen de Zuid-Oostelijke helling van het Seseangebergte, in het complex Bori'.

55 Lempo is een dorp op de Zuidelijke helling van het Seseangebergte, in het complex Bori' gelegen.

$57 \mathrm{Ta}^{\prime} \mathrm{ba}^{\prime}$ is een dorp op de Noordelijke helling van het Seseangebergte.

59 Pangala' is een landschap in het N.W. van Tana Toradja.

61 Baruppu' is een complex in het Noorden van het landschap Pangala'.

63 Belau is een landschap in het Westen van het Rantepaose, aan de linkeroever van de Masuppu'-rivier. 
51 Ze boog neer tot $A^{\prime}$ kung, ze wiegelde zacht heen en weer.

52 Ze leverde een hoen op, uit haar ontstond een kakelaar.

53 Ze boog neer tot de Sesean, ze wiegelde zacht heen en weer.

54 Ze werd tot een grote draagkorf, uit haar ontstond een mand om in te dragen.

55 Ze boog neer naar Lempo, ze wiegelde zacht heen en weer.

$56 \mathrm{Ze}$ werd tot een zonnehoed, uit haar ontstond een voorwerp tot beschaduwing.

57 Ze boog neer naar Ta'ba', ze wiegelde zacht heen en weer.

58 ze leverde rotan op, uit haar kwam voort hetgeen afgeschrapt wordt.

59 Ze boog neer naar Pangala', ze wiegelde zacht heen en weer.

60 Ze leverde koffie op, uit haar kwam voort hetgeen gekookt wordt.

61 Ze boog neer naar Baruppu', ze wiegelde zacht heen en weer.

62 Ze leverde plantengif op, uit haar ontstond een klein blaasroer.

63 Ze boog neer naar Belau, ze wiegelde zacht heen en weer.

64 Ze leverde rietgras op, uit haar kwam voort hetgeen men in een hoop met de armen kan omvatten.

65 Ze boog neer naar Tabang, ze wiegelde zacht heen en weer.

$64 \mathrm{ria}$ is alang-alang Imperata. "hetgeen men kan omvatten" is een parallelle omschrijving van rietgras.

65 Tabang is een landschap aan de rechteroever van de Masuppu'rivier, een der landschappen van het complex Tandalangngan van Mamasa. 
66 Iamo mendadi bai, ia kombong kalle'-kalle'.

67 Ia kumpang ri Piongan, ia kakumbaa'-baa'.

68 Iamo mendadi tuju, ia kombong andi'-andi'.

69 Ia kumpang lako Sasak, ia kakumbaa'-baa'.

70 Iamo mendadi masak, ia kombong rau-rau.

71 Ia kumpang rokko Lambung, ia kakumbaa'-baa'.

72 Iamo mendadi kurin, ia kombong pa'to'-pa'to'.

73 Ia kumpang ri Simbuang, ia kakumbaa'-baa'.

74 Iamo mendadi kapa', ia kombong ri pamiso'.

75 Ia kumpang ri Palesan, ia kakumbaa'-baa'.

76 I amo mendadi pattung, ia kombong ao' gading.

77 Dipobala-bala tedong, dibontongan karambau.

78 Titaa tallumo tallang, tipa'duamo totiang.

79 Unnola rampe matampu', unnola rampe matallo, unnola tangngana padang.

66 "een schreeuwend wezen" is een parallelle omschrijving van een varkentje.

67 Piongan is een landschap in het Westen van het Rantepaose.

68 "het geknepene" is een parallelle omschrijving van biezen, omdat die voordat men er matten of zakken van gaat vlechten eerst geknepen worden, opdat ze goed plat worden.

69 Sasak is een nederzetting in het landschap Bettuang, in het Westen van het Rantepaose. Er wordt daar goud gevonden in de rivier. Het Nederlands-Indische Gouvernement heeft daar indertijd een mijnbedrijf gehad om goudlagen op te sporen.

71 Lambung is een complex in het landschap Tapparan, tussen de landschappen Madandan en Ma'kale in gelegen. In dat complex wordt pottenbakkerij bedreven. 
66 Ze leverde varkens op, uit haar kwamen schreeuwende wezens voort.

67 Ze boog neer naar Piongan, ze wiegelde zacht heen en weer.

68 Ze leverde biezen op, door haar was er het geknepene.

69 Ze boog neer naar Sasak, ze wiegelde zacht heen en weer.

70 Ze leverde zuiver goud op, door haar was er het vermengde goud.

71 Ze boog neer naar Lambung, ze wiegelde zacht heen en weer.

72 Ze leverde kookpotten op, door haar waren er de rijstkookpotten.

73 Ze boog neer naar Simbuang, ze wiegelde zacht heen en weer.

74 Ze leverde katoen op, door haar was er de van pitten gezuiverde kapok.

75 Ze boog neer naar Palesan, ze wiegelde zacht heen en weer.

76 Ze werd tot dikke bamboe, door haar was er dikke gladde bamboe.

77 Ze wordt gebezigd voor de buffelstal, van haar wordt een karbouwenkraal gemaakt.

78 De bamboe wordt over drie gebieden verdeeld, de uitspruitsels zijn over twee streken gesplitst.

$79 \mathrm{Ze}$ is over het Westen heengegaan, ze is over het Dosten heengegaan, ze is over het middengebied heengegaan.

72 pa'to'-pa'to': kookpotten waarin water wordt gekookt voordat de rijst er in gedaan wordt.

73 Simbuang is een landschap in het Z.W. van het Ma'kalese.

75 Palesan is een landschap in het $W$. van het Ma'kalese aan de rechteroever van de Sa'dan-rivier.

76 pattung is de bombu betung, een dikke bamboesoort (Dendrocalamus asper). $a o^{\prime}$ gading is de bambu aur, een dikke bamboesoort met gladde stam (Dendrocalamus strictus). 
80 Dibongsoran 10lo' mai, diulo' sambali' mai, bu'tu lamban diong mai.

$81 \mathrm{Ma}$ 'tete batumo tallang, unnola landa Sarira.

82 Kasirempunganna tallang, kakendenanna totiang.

83 Sae mengkanna i Kesu', mentunanna' ri Bangkudu.

84 Tallang tumombo i Kesu', umbalumbun ri Bangkudu.

85 Nakua kadanna tallang, randan pudukna totiang:

86 "Ke uai tang kulamban, ke Sa'dan tang kuorongi.

87 Iri'ko-iri'ko angin, simboko-simbo darinding.

88 La napoteteko tallang, la naolako totiang."

89 Sae mengkanna i Batu, mentunanna' ri Siguntu'.

90 Nanai longke ditanan, tambu lebu' diosokan.

91 Tumajang ditanan misa, nabongsoran diong mai, naulo' sambalin mai.

92 Sae mengkanna i Tallang, mentunanna' i Darusa.

93 Napilei ma'lombokna, natiro tikallebona, to tipara'da-ra'danna.

94 Nanai longke ditanan, tambu lebu' diosokan, tumajang ditanan misa.

83 Bangkudu is een streek tegen een uitloper van het rotsgebergte Kesu' gelegen, behorende tot het territorium van het dorp Ba'tan. 92 Tallang is een gehucht in de kampung Sangpolobungin. Darusa is de naam van een bepaalde plek en de naam van een tongkonan, een oorsprongshuis, in het dorp Sangpolobungin. 
$80 \mathrm{Ze}$ is uit het Zuiden neergelaten, ze is naar beneden gelaten van de overzijde, $z e$ is verschenen overgekomen daar vandaan.

81 De bamboe heeft de stenen trap betreden, ze is over de welving van de Sarira-rotsgroep gegaan.

82 De plaats van het bijeen zijn van de bamboe, de plaats waar de uitspruitsels oprijzen.

83 Ze kwam op de Kesu', ze verbleef in Bangkudu.

84 De bamboe groeide op de Kesu', ze schoot welig op in Bangkudu.

85 De bamboe zegt, de rand der lippen van de uitspruitsels luidt:

86 'Wanneer ik het water niet oversteek, wanneer ik de rivier niet overzwem.

87 Waai gij dan steeds, wind: strijk gij er dan steeds langs, koeltje!

88 Dat de bamboe u betrede, de uitspruitsels over u heen lopen."

89 Ze kwam in Batu, ze verbleef in Siguntu'.

90 Het is de plaats waar de van verre zichtbare geplant is, de wijd-gestoelde in de grond is gezet.

91 Ze stak uit apart geplant, men liet ze van boven af neerkomen, men liet ze naar beneden gaan van de overzijde.

92 ze kwam aan in Tallang, ze verbleef in Darusa.

93 Ze koos uit hetgeen de vorm heeft van een dal, ze zag om naar hetgeen hellend is, naar hetgeen, waar het stil is.

94 Het is de plaats, waar de van verre zichtbare geplant is, de wijd-gestoelde in de grond is gezet, ze stak uit apart geplant. 
95 Tallang tang natanan tau, tang napatumbo to lino, tang naosok tau mata.

96 Tallang pantananna puang, pa'parorakna dewata, pa'parumaka-makanna.

97 Mennuaka' doti langi', membola patola gajang.

98 Tallang ma'buku bulaan, mengkalopak kiding-kiding.

99 Tisea' tinggi lapana, merranga' ta'bi bulaan, mendaun seleng sirenden.

100 Karua langngan sibarrung, annan langngan siajoka, be'dang pantan bali-bali,

101 Kasalle nairi' angin, 1obo' nasimbo darinding, napaeran talimpuru', nasenggong la'te mamara.

102 Iapi anna diala, anna tikambe limanta, anna ma'din dipobate, unnio dipobandera, tanduk dipotelo-telo.

103 La sipassakkemo' tallang, la sibenmo' tuo-tuo. 104 Masakkeko, kumasakke, tabassing makole-kole.

102d,e "wimpel" en "pluim" zijn parallelle omschrijvingen van de bate, omdat men een rode doek aan de bamboestengel bevestigt en een rijstbos aan het uiteinde daarvan bindt.

104 Wat de heilbeden in str. 103-107 betreft, is te vergelijken The Chant, p. 36, IA, str. 195-199.

[De vertaling van str. 198b daarvan moet luiden:

"May our offspring be called Rippung". In de voorafgaande strofen wordt zowel in The Chant als in deze Gelong Tallang het inclusieve bezittelijk voornaamwoord gebezigd, maar in str. 198b van The Chant en in str. 106b van deze Gelong het exclusieve bezittelijk voornaamwoord, omdat aan elk van de partners een eigen heilbrengende naam wordt toegekend. ] 
95 De bamboe is niet door mensen geplant, niet door de mensen van deze aarde gepoot, niet door mensen van vlees en bloed in de grond gezet.

96 De bamboe is het door de heer geplante, dat, wat de god zich overal heen deed uitbreiden, dat, wat hij overal heen deed uitstoelen.

97 Ze heeft wortels als de doti langi'-doek, ze heeft uitspruitsels edel als het kostbare oude weefsel met een edele kruisfiguur.

98 De bamboe heeft gouden knopen, de lagen van haar bast zijn als schitterende stukjes goud van een vrouwensieraad.

99 De haartjes er van zijn verspreid als donkerrode kralen, ze heeft twijgjes als gouden bloesems, ze heeft bladeren als op elkaar volgende seleng-doeken.

100 Acht gaan in paren omhoog, zes gaan twee aan twee omhoog, ze verheffen zich ieder met zijn partner.

101 Ze worden groot, terwijl de wind er over heen waait, ze groeien weelderig, terwijl het koeltje er langs strijkt, de storm hen heen en weer zwaait, de bliksemschichten in de droge tijd hen doen schudden.

102 Dan pas wordt ze gehaald, wanneer onze handen uitgestoken worden, opdat ze als bate gebezigd worde, wanneer men ja zegt wordt ze als wimpel gebezigd, wanneer men van ja knikt wordt ze als pluim gebruikt.

103 Laten de bamboe en ik elkaar zegenen, laten wij elkaar een lang leven wensen.

104 Moge gij gezegend en ik gezegend zijn, mogen wij ieder een lang leven hebben. 
105 Mukeanak, kukeanak, tabassing tumakin pea.

106 Anakmu disanga Daeng, anakki disanga Reppung.

107 Anna daeng-daeng sugi', anna reppung bala tedong. 
De lofzang op de bamboe (E III, 105-107)

105 Moogt gij kinderen hebben en ook ik, mogen wij ieder kinderen dragen op de heup.

106 Mogen uw kinderen Daeng genaamd worden, mogen onze kinderen Reppung genaamd worden.

107 Mogen zij rijkdommen voor zich vergaderen, mogen hun buffelstallen een menigte van buffels bevatten. 
H. van der Veen - 978-90-04-28716-7 Downloaded from Brill.come4/26/2023 02:54:12PM via free access 


\section{Inleiding}

Voor de bate kiest men een tallang-bamboestaak die overhelt naar het N.0., de richting van de leven schenkende goden. Die bamboe wordt dan op rituele wijze gekapt (vgl. str. 7v., 10) en vervolgens neergelegd in het huis van degene die het feest houdt (ma'palundan bate); zij blijft daar een nacht liggen. De volgende dag wordt de bate versierd en daarna opgericht.

Aan de bate wordt in Kesu' een lange, rode doek bevestigd, in Tikala worden er verschillende stukken kain aan vast gemaakt, tombi to Luur' geheten, in de niet-dichterlijke taal bandera (vlag, banier). Aan de bamboestaken, die op de dodenfeesten worden opgericht, worden de oude tjindai-weefsels, maa' geheten, bevestigd. Voorts wordt aan het uiteinde een bos rijst gehangen.

Terwijl de bate versierd wordt, wordt de gelong bate gezongen. Daarna wordt zij opgericht. Bij die gelegenheid wordt een hoen geslacht en het vlees daarvan in bamboe gekookt (dipiong). Deze piong wordt tezamen met een piong gekookte rijst met de bate in optocht naar de feestplaats (kala'paran) gebracht en daar geofferd door de to ma'dampi. De piong worden bij het ondereinde van de daar opgerichte bate neergelegd. Allen, die bij het maro-ritueel in trance geraakt zijn, moeten zo'n piong met gekookte rijst, met een Dracaenablad afgedekt bij de bate neerleggen. Die worden dan alle, of een gedeelte er van, ook als offer aangeboden.

$\mathrm{Na}$ het einde van het maro-ritueel wordt de bate weer van versierselen ontdaan (ma'sossoan bate, vgl. soso' = minder worden). De bamboestaak wordt dan weer overeind gezet en men laat die dan verder op de feestplaats staan.

Deze tekst is opgeschreven uit de mond van de to minaa Todinglele van To'jasa (Riu, landschap Tikala). 
Tekst

1 Randuk tumengkai suru', tumetang passara'kasan, suru'na bate manurun.

2 Messaile rokko bamba, mentiro rokko sulunan.

3 Tallang nabasa matanna, nata'pai pentirona, nabasa pa'penununna.

4 Misa'ri ma'laen dadi, paillo-illo dadinna.

5 Pasuloan garaganna, paarrang tampa rapa'na.

6 Rokko narandean londong, napa'barra' maisoi.

7 Manoka nalelleng bulo, la nagaraga arrusan, la nasandi' giu-giu.

8 Manoka nalelleng $1 a^{\prime} b^{\prime}$, nalempa-lempa mataran.

$9 \mathrm{Ma}$ 'din ia dilelleng gelong, ma'din ia dilelleng bate, digaraga tombi to Luwu.

$10 \mathrm{Ma}$ 'din la dilelleng tabang, diala tallu lolona.

1 suru', 1t1. kam, heeft de betekenis van "zoenoffer/reinigingsoffer", ook vaak eenvoudig "offer". passara'kasan is een afleiding van sara'ka' "kam", dat eveneens de betekenissen heeft van "zoenoffer/reinigingsoffer/offer"; passara'kasan: ritueel van het zoenoffer. manurun heeft de betekenis: van het uitspansel neergedaald.

6 Deze strofe slaat op de twee piong-offers, zie Inleiding.

7 De bedoeling van deze strofe is, dat men deze bamboe-tallang op rituele wijze omhakt na het brengen van een offer.

8 De bedoeling van deze strofe wordt duidelijk door str. 9: 'Men mag hem door middel van een rituele zang kappen". Ook mag de tallang voor de bate slechts gekapt worden na het brengen van een offer, vgl. str. 10 . u Zlempa-Zempa = uZlampak-Zampak: omhakken, kappen. De "Luwu'se banier" is de parallelle benaming van bate. 
Vertaling

1 Men gaat beginnen het offer te brengen, het reinigingsoffer aan te richten, het offer voor de bate manumin.

2 Men ziet om benedenwaarts naar de vestiging, men kijkt benedenwaarts naar de opening, waar men het dorp binnengaat.

3 Hun oog valt op de bamboe, hun blik vestigt zich daar op, hun oplettend vermogen wordt er door getroffen.

$4 \mathrm{Zij}$ (d.i. de bate) is uniek, van een uitzonderlijke geboorte, $z i j$ is van een schitterende wording.

5 Lichtend is haar gestalte, glanzend haar goed geproportioneerde vorm.

6 Men houdt voor haar een haan op de vlakke hand, men heeft goed wit gestampte rijst voor haar nodig.

$7 \mathrm{Zij}$ wil niet, dat men haar als dunne bamboe hakt, als zou men er pijltjes van maken, dat men er van afsnijdt voor het vervaardigen van de scherpe

uiteinden van de pijltjes van het blaasroer.

$8 \mathrm{Zij}$ wil niet, dat men haar met een kapmes kapt, met het scherpe omhakt.

9 Men mag haar met een rituele zang kappen, men mag er een bamboestaak van hakken, er een Luwu'se banierstandaard van maken.

10 Men mag haar kappen door middel van Dracaenabladeren, men mag haar halen door middel van de plant met de drie jonge bladeren.

9 Aan de bamboestaken, die op de dodenfeesten worden opgericht, worden de oude tjindai-weefsel, maa' geheten, bevestigd.

10 De bedoeiing hiervan is dezelfde als die van str. 9. Men mag haar pas kappen na het bovengenoemde offer dat op Dracaena-bladeren neergelegd wordt. De offers, die op het maro-feest verricht worden, worden niet op pisang-bladeren, maar op Dracaena-bladeren neergelegd.

tallu Zolona: "de drie jonge bladeren" is de parallel van tabang: "Dracaenabladeren", zoals tallu bulinna "de drie aren" de parallel is van pare: "de rijstplant". 
11 Napalele tama tondok, turarrak tama pangleon, napopessa'de alangna.

12 Namasiang to makale', nabau banggoi lako.

13 Napatakinni tonapa, napatondon lolo tabang.

14 Bendan patukumo bate, tuo lampo'mo bandera, ungka1lo tangngana langi'.

15 Malea unnarrang tondok, borrong umbangko pangleon, ussarrang sa'de banua.

16 Malea unnarrang langi', borrong umbangko batara, ussarrang barrena allo.

17 Natobokki bai tora, sola londong maupa'na.

18 Tabang tang balle naserek, lassigi' tang kira-kira.

19 Bulaan tiseno diong, naorongi londo'-1ondo'.

20 Daun tang balle naserek, baneran tang kira-kira.

21 Bulaan tiseno diong, diorongi pao makkan.

22 Ambajang katarananna, pao meti'doan elo'.

12 bou is de uitspraak in Tikala van baju: baadje; banggo: "versierd met allerlei fraais"; banggo hangt samen met anggo-anggo: "uitdossen, opsieren met versieringen".

14 Zampo': een kegelvormige zak van de bladschede van de arecapalm met pisangblad overtrokken, aan welke puntige zakjes van in pisangblad gekookte kleefrijst worden opgehangen; deze zakjes worden opgestapeld bij de offerplaats tijdens het menommu pareoffer aan het begin van de rijstoogst.

15 De Dracaenabladeren verlenen de bate een rood schijnsel. sa'de banua, 1t1. de zijkant van het huis.

17 bai tora, $1 \mathrm{tl}$. een varken, dat al lange slagtanden heeft. "zijn haan, die geluk aanbrengt", d.i. de haan, die ten behoeve van de bate zal geofferd worden. 
11 Men verplaatst haar het dorp in, men brengt haar juichend de nederzetting in, men loopt er mee op het erf tussen zijn rijstschuren.

12 En de volgende dag in de morgen, bekleedt men haar met een fraai versierd baadje.

13 Men bindt er korte zwaarden om, men bindt er jonge Dracaenabladeren in een bos omheen.

14 De bamboe standaard staat opgericht als een puntig toelopende hoop rijstbossen, de banier zet zich uit als een kegelvormige zak, bijna reikend tot het midden van het uitspansel.

$15 \mathrm{zij}$ is zó rood, dat $\mathrm{zij}$ het dorp verlicht, $z i j$ is zó rood, dat haar schijnsel de nederzetting omvangt, dat $z i j$ het erf doet gloeien.

$16 \mathrm{Zij}$ is zó rood, dat $z i j$ het uitspansel verlicht, $z i j$ is zó rood, dat haar schijnsel het uitspansel omvangt, dat $z i j$ de stralen van de zonneschijf doet gloeien.

17 Men steekt er een groot varken met een mes voor, en zijn haan, die geluk aanbrengt.

18 Men scheurt echte Dracaenabladeren af, onbedriegelijke drakenbloedbladeren.

$19 \mathrm{Er}$ is goud op gezeefd, ze worden in stapels van repen gesneden.

20 Men scheurt echte Dracaenabladeren, onbedriegelijke drakenbloedbladeren.

$21 \mathrm{Er}$ is goud op gezeefd, een onrijpe mangga in repen voor gesneden.

22 Een grote mangga op de tijd, dat hij nog heel zuur is, een mangga, die iemand doet watertanden.

22 katarananna (een afleiding van taran: scherp) betekent 1 tl. op de tijd, dat hij scherp is, d.i. heel zuur van smaak, wanneer hij half rijp is. Dit en het tweede lid van de strofe zijn overdrachtelijke uitdrukkingen met de betekenis van: het varkensvlees, dat geofferd wordt. 
23 Metamba rekkemi puang, meongli' rekke deata.

24 Tappu tanete natendeng, lombok nakundala-dala.

25 Sae tongan, turun tongan, tae' dikita lumalle, tang koong passirukanna.

26 Ampu lembang lan di to'na, ia umpakamangkai, umpakare'na-re'nai.

27 To minaa sia pira, ia umpakamangkai, umpakare'na-re'nai.

23 meongli': "aanroepen" is de intensieve vorm van meoli: roepen.

24 "Men looft alle bergen", t.w. de goden, die daar huizen. nakundala-dala, 1tl. men omheint met bamboetjes; het heeft hier de overdrachtelijke betekenis van: men prijst de dalen met uitnodigende loftuitingen, $\mathrm{nl}$. op de goden, die rondom de dalen huizen.

25 koong $=$ kojong, 1 tl . wond.

26 "het ondereinde er van", nl. van de bate. 
23 Men roept de heren Noordwaarts aan, men roept Noordwaarts tot de goden.

24 Men looft alle bergen, men prijst de dalen met uitnodigende loftuitingen.

$25 \mathrm{Zij}$ komen in een machtig aantal, zij komen in groten getale achter elkaar, men ziet hen niet komen, men ziet niet de overblijfselen van hun bezigheid van het opscheppen der spijzen.

26 De gebieders van het landschap, die zich dicht bij het ondereinde ervan bevinden,

zij verorberen het geheel en al,

zij vermanen tot ontzag.

27 Ook enige priesters,

$z i j$ verorberen het geheel en al,

zij vermanen tot ontzag. 
H. van der Veen - 978-90-04-28716-7 Downloaded from Brill.come4/26/2023 02:54:12PM via free access 
TEKST F

OSSORAN BUGI'

Inleiding

Deze tekst, bevattende "de overlevering van de zang ter gelegenheid van het bugi'-feest", werd opgetekend uit de mond van $\mathrm{Ne}^{\prime}$ Gassing, afkomstig uit Lempo, landschap Tikala.

Het bugi'-ritueel loopt in zeker opzicht parallel met allerlei verrichtingen van het maro-ritueel. Ook tijdens verrichtingen van dit feest treden allerlei trance-verschijnselen op. Het onderscheidt zich van het maro-feest, omdat het niet gevierd wordt als een feest in algemene zin als voorbereiding op het in de cyclus volgende merok-feest, in welk maro-feest dan het bijzondere doel van het uitdrijven van ziekte een voorname plaats inneemt.

Het bugi'-ritueel heeft het bepaalde doel ziekte uit de adatgemeenschap te weren en wordt vaak in gevallen van epidemische ziekten verricht. In dit ritueel wil men eer bewijzen aan de boze geest, genaamd To Paragusi, of To Parakusi. Naar de voorstelling, die men van hem heeft, moet hij er wit uitzien en een hoge, voorname gestalte hebben, een soort weerwolf-verschijnsel, dat de lever van mensen en dieren eet. De Hr. Tammu meent, dat Paragusi een verbastering is van Portugis. Dit vermoeden zou gesteund kunnen worden door het in de teksten meermalen voorkomende gebruik ongewone verschijnselen of figuren een buitenlandse naam te geven, bijv. Ara' (Arabisch) of Balanda (Hollands); vgl. ook de uitdrukking in de bugi'-zang: bugi' anggara'ka inde Balanda tonganra'ka: ben ik hier een bugi'-demon, die zich zo maar aanstelt, ben ik als een echte Hollander.

Er wordt wel gedacht, dat die geest uit de Boeginese landen afkomstig is.

In het maro-ritueel wordt de term $b u g i^{\prime}=$ demon nog al eens gebezigd, bijv.: to narampa, of naala, bugi': degene, die door een demon geroofd, gevangen genomen, bezeten is = bugiran; to bugi': degene, die tijdens het maro-ritueel behandeld wordt; untammi bugi': de bugi'geest tegemoet gaan, is de benaming van een offer, dat buiten het dorp gebracht wordt, voordat men de hoofdriten verricht. 
Het bugi'-ritueel kwam in de latere jaren in het Ma'kalese veelvuldiger voor dan het maro-feest, dat daar door het Ned.-Indisch Bestuur verboden was; in het Rantepaose daarentegen kwam eerstgenoemd ritueel minder vaak voor dan het, daar wèl gevierde, maro-feest.

Een beschrijving van het bugi'-ritueel wordt gegeven in Nobele (1926), 1-143. Voorts hebben Dr. en Mrs. Eric Crystal over dit ritueel in het Ma'kalese allerlei onderzoek gedaan en er een film van opgenomen, waarvan zich een copie bevindt in het Etnografisch Instituut van de Universiteit van Leiden.

Het ritueel van het bugi'-feest bestaat uit het opzetten van stijlen van bombu betung, aan welke de uitgeplozen gele bladeren van de arenpalm bevestigd worden, bij welke de offers aan de bugi'-geest worden neergelegd.

Over tranceverschijnselen handelt deze bugi'-zang op sobere wijze. Uit de gelong maro bekende termen als malangi', tumbang, sala padang, kandeatan, kasaean, kataman komen er niet in voor.

De uit de bovenwereld afkomstige Dracaenaplanten worden ook in deze zang luisterrijk vermeld.

De te duchten geesten aan wie in deze zang in huldigende bewoordingen eer bewezen wordt, worden gedacht aan de andere zijde van het uitspansel te zijn, str. 20; hun zeden en gewoonten en verrichtingen worden in de daarop volgende strofen beschreven, in welke wordt verhaald, dat $z i j$ in prauwen varen, in het bos gaan lopen en ten slotte de markt bereiken, waar de god vertoeft; daar zijn mensen bezig met het laten vechten van hanen, str. 23-77. De in trance gekomenen bereiken dan het gebied van Suso en Te'tekan in het complex Badjo' in het Palopose gelegen en stijgen op naar het gebergte Sinadi (in het Boeginees Sinadji), het voorgebergte van het complex Latimodjong, en komen tenslotte aan in het complex Salu, in het onderlandschap Nonongan van het landschap Kesu' gelegen. Zij gaan dan verder naar de adatgemeenschap Lolai, str. 78-92, en bereiken Mengka, waar de Dracaenaplanten zijn ontsproten, over welker geneeskracht en toepassing wordt gesproken in str. 93-99.

De in trance zijnden komen dan aan in een liefelijk dorp en richten er een huis op, waarvan de materialen kostbaar zijn, t.w. bijzondere sieraden en oude weefsels van hoge waarde; het wordt beschreven in str. $103 \mathrm{vlgg}$. Men treft in het dorp veel zeugen aan en een menigte buffels. Wat zou men meer verlangen? Totaal alles geven ons de goden, 
alles, wat dan ook, reiken de goden ons toe, wanneer ieder het aan de betreffende god vraagt, str. 133 en 134. 
Tekst

1 Mane kulesena tondok, mane kulonda-londana.

2 Tondok boro toda inde, boro pangrantean toda.

3 Tondok natikui tabang, natalimbung danga-danga.

4 Tabang kumombo i langi', umbalumbun di batara.

5 Kumangnga-mangngai aku, pusakna' umpenajanni.

6 Sadio-diona mai, sauntangngana lalanna.

7 Sae kumombo i buntu, umbalumbun di tanete.

8 Anna songlo' dao mai, anna lao sambal in mai, bu'tu lamban diong mai.

9 Sae kumombo i liku, umbalumbun di uai.

10 Kendek lu langnganko mai, rubakko to' bura-bura.

11 Kendekmi kapadanganna, dikapaan-paananna.

12 Sae kumombo i buntu, umbalumbun di tanete.

13 Merruaka' doti langi', mellolo ta'bi bulaan.

14 Karua langngan sirondong, annan langngan siajoka.

15 Tabang malea ura'na, tabang borrong uaka'na.

4 kumombo is een nevenvorm van tumombo: groeien, opkomen. 5,6 Deze strofen komen ook geregeld voor in de Maro-zangen.

13 mermuaka' = mennuaka': 'wortels hebben" zijn afleidingen van uaka' = aka': 'worte1"; het prefix merr- komt zelden voor in het Sa'danToradjaas. De verdubbeling van de $r$ is misschien te danken aan een analogievorming van mennuaka'。 


\section{Vertaling}

1 Pas heb ik het dorp betreden, pas ben ik er recht op afgegaan。

2 Het vriendelijke dorp hier, de prettige nederzetting toch.

3 Het dorp wordt door Dracaena-planten omgeven, kembang sepatu-bloemen groeien er rondom.

4 De Dracaena-planten zijn voortgesproten uit de hemel, ze zijn hoog opgeschoten in het uitspansel.

5 Ik ben er verbaasd over, ik ben verbijsterd, wanneer ik er aan denk.

$6 \mathrm{Zij}$ komen steeds meer hierheen, totdat zij halverwege zijn.

$7 \mathrm{Zij}$ sproten voort uit de bergen, zij zijn hoog opgeschoten op het gebergte.

8 Daarop zijn ze daar van boven neergedaald, zijn zij vandaar hierheen gekomen, zij zijn vandaar overgekomen hier verschenen.

$9 \mathrm{Zij}$ sproten voort uit de diepe kolk, zij zijn hoog opgeschoten in het water.

10 Stijg op naar boven, breek door de plaats van het schuimende heen.

11 Toen kwam het land naar boven, op de plaats van het zichtbare.

$12 \mathrm{Zij}$ sproten voort uit de bergen, zij zijn hoog opgeschoten op het gebergte.

$13 \mathrm{Zij}$ hadden wortels prachtig als het doti langi'-weefse1, er sproten bloemen uit als goud.

14 Acht stonden er bij elkaar, zes waren aaneen verbonden.

15 De Dracaenaplanten hebben rode nerven, de Dracaenaplanten hebben vuurrode wortels. 
16 Giring-giring lan di to'na, garente lan kurapakna。

17 Kumangnga-mangngai aku, pusakna' umpenajanni.

18 Kisape-sape daunna, kipelamba' baneranna.

19 Sadio-diona mai, sauntangngana lalanna.

20 To dio leko'na langi', nasapa' batu apian.

21 To dio manan baine, sola makkundai-dai.

22 Ma'dinko kita kusomba, kupangurande-randei.

23 To tang nakitta' masiang, tang nalomban bao-bao.

24 To ma'kurin-kurin gallang, To ma'pesangle bulaan.

25 To tang kumande makula', tang rumundu bura bo'bo'.

26 Ia kumande mamata, ia manginta manglaa'.

27 To umpa'nasui allo, to umpa 'to' kamammuran.

28 Manasu nairi' angin, re'de nasimbo darinding.

29 Kumangnga-mangngai aku, pusakna' umpenajanni.

18 kipelamba' baneranna, 1tl. wij trekken zijn bladeren blad voor blad af.

20 to dio Zeko'na Zangi' heeft de betekenis van: zij die aan de andere zijde van de horizon zijn, die buiten onze horizon zijn. nasapa' batu apian: "zij die begrensd worden door de steen vol vuur" heeft waarschijnlijk de betekenis van: zij die aan de andere zijde van de donder en de bliksem vertoeven; "de steen vol vuur" betekent misschien de donder en de bliksem.

21 In makkundai: "een vrouwensarong dragen" heeft de hamzah van het prefix $m a^{\prime}-$ zich aan de volgende $k$ geassimileerd. Met regel b worden misschien mannen bedoeld, die zich als vrouwen gedragen en vrouwenkleding dragen, zie burake tambolang in $W b ., 86 \mathrm{~b}$, en vgl. de bajasa bij de Bare'e sprekende Toradja's, zie Adriani, V.G., II, 196 en de bissu bij de Boeginezen, zie Matthes, "Over de bissoes", Verh. der Kon. Akademie van Wetenschappen Afd. Letterkunde, 7 (1872). 
16 Er zijn belletjes in de stam,

zij geven een trillend geluid in de oksel van de tak.

17 Ik ben er verbaasd over,

ik ben verbijsterd, wanneer ik er aan denk.

18 Wij trekken zijn bladeren af,

wij halen zijn bladeren er een voor een af.

$19 \mathrm{Zij}$ komen steeds meer hierheen, totdat zij halverwege zijn.

$20 \mathrm{Zij}$ die aan de andere zijde van het uitspansel zijn,

$z i j$ die begrensd worden door de steen vol vuur.

$21 \mathrm{Zij}$ die daar zijn, waar alleen vrouwen zijn, en $z i j$ wier kleding een vrouwensarong is.

22 Laat ik u toch mogen huldigen, ik $u$ een gave op de vlakke hand mogen aanbieden.

$23 \mathrm{Zij}$ die niet door het licht beschenen worden, die het schijnsel niet betreden.

$24 \mathrm{Zij}$ die kookpotten hebben van messing,

zij die scheplepels hebben van goud.

$25 \mathrm{Zij}$ die geen gekookte spijzen eten,

$z i j$ die het rijstewater niet aanraken met de mond.

$26 \mathrm{Zij}$ eten het ongekookte,

zij volgen de rouwgebruiken en bereiden de vleesgerechten rauw met zuur en Spaanse peper.

$27 \mathrm{Zij}$ die de zonnegloed gebruiken als vuur om op te koken, zij die de tijd dat het warm begint te worden bezigen als heet water waarin hun rijst gekookt wordt.

28 Wanneer het gekookt is waait de wind er over, wanneer het aan het zieden is strijkt het koeltje er langs.

29 Ik ben er verbaasd over, $i k$ ben verbijsterd, wanneer ik er over denk.

23 kitta' (de intensieve vorm van kita): buitengewoon zien; tang nakitta' masiang, 1t1. zij die niet door het daglicht bekeken, getroffen worden, t.w. de geesten, die buiten het uitspansel vertoeven, niet in de ruimte onder het uitspansel.

bao-bao, in de meeste streken bajo-bajo: "schijnsel"; in het gebied van Tikala valt de $j$ tussen $a$ en o of $u$ meestal weg, bv. kajo: "grauwe reiger", luidt daar kao, kaju: "hout" luidt daar kau.

25 rumundu hangt samen met dundu: drinkgerei met de mond aanraken.

26 manginta: de rouwgebruiken volgen volgens welke men gedurende drie of vijf dagen geen gekookte spijzen eet.

27 umpa'to': water op het vuur aan de kook brengen om daarin de rijst te koken. 
30 Ke mellao sangrapui, ke ke'de' sangpemanakki,

31 tallu ratu' sangke'deran, sangsa'bu sangtiangkaran.

32 Sumpio padang naola, lento batu napolalan.

33 Sadio-diona mai, sauntangngana lalanna.

34 Sae mengkanna i Bugi', mengkaendek ri Balanda.

35 To di Balanda isinna, to di Bugi' petaanna.

36 To tuo langngan rundunna, to sumissang beluakna.

37 Lantik isinna lumingka, rundunna mallai-lai.

38 To umpalingka ulunna, to unturu' tingajona.

39 Kumangnga-mangngai aku, pusakna' umpenaanni.

40 Sadio-diona mai, sauntangngana lalanna.

41 Umpilei buntu borrong, tanete ma'lia-lia.

42 To ma'rinding-rinding lalan, to ma'kulambu lolalan.

43 Kaliling nasolan torro, rangki' nasangpaningoan.

44 Sadio-diona mai, sauntangngana lalanna.

45 Sae mengkanna i tasik, mengkaendek ri uai.

46 Untongkonni laa' lembang, unnesung pussa orongan.

35 Regel a betekent, dat het gebit niet gevijld wordt; regel b betekent, dat de voortanden niet afgeplat worden; petaa: voortanden, die zichtbaar worden bij het lachen (metaa).

$41 \mathrm{ma}$ 'lia-lia: roodachtig.

46 pussa is een nevenvorm van pungsa: omgebogen uiteinde van de balk van een huis of rijstschuur. 
30 Wanneer de hele verwantschap op weg gaat, wanneer de ganse familiegroep optrekt,

31 dan gaan er driehonderd tezamen optrekken, gaan er duizend tezamen zich opmaken.

32 De grond die zij betreden beweegt op en neer, de steen der rotsen beven waar zij langs gaan.

$33 \mathrm{Zij}$ komen steeds meer hierheen, totdat zij halverwege zijn.

$34 \mathrm{Zij}$ betreden het gebied der Boeginezen, zij stijgen op tot de streek der Hollanders.

35 Hun gebit is als dat der Hollanders, hun voortanden zijn als die der Boeginezen.

36 Hun haren groeien omhoog, hun haarbos is als die van hen bij wie ze tegen de draad ingaan.

37 Het afgevijlde van hun tanden beweegt, hun haardos gaat steeds weg.

38 Het zijn lieden, die hun hoofd doen lopen, het zijn lieden, die hun voorhoofd volgen.

39 Ik ben er verbaasd over, $i k$ ben verbijsterd, wanneer ik er over denk.

$40 \mathrm{Zij}$ komen steeds meer hierheen, totdat zij halverwege zijn.

$41 \mathrm{Zij}$ kiezen een vuurrode berg, een roodachtig gebergte.

$42 \mathrm{Zij}$ omringen $\mathrm{zich}$ met een wand op de weg, $z i j$ omgeven zich met een gordijn onderweg.

43 Een bord van omgebogen rotan hebben $z i j$ bij $z i c h$, wanneer $z i j$ ergens verblijven, een mandje van de gevlochten nerven van de aren-palm daar spelen zij met elkaar mee.

$44 \mathrm{Zij}$ komen steeds meer hierheen, totdat zij halverwege zijn.

$45 \mathrm{Zij}$ gaan over de zee, $z i j$ stijgen op tot de wateren.

$46 \mathrm{Zij}$ zetten zich op de voorplecht van de prauw, zij zitten op de steven van het vaartuig. 
47 Lembang sura' tang ma'kada, orongan tang ma'bisara.

48 Kumangnga-mangngai aku, pussakna' umpenajanni.

49 Lembang sangsa'bu situru', annan ratu' sangke'deran.

50 Tipasirri' issi salu, tibibi' bete uai.

51 Napobua' lembang sura', napaten 1opi orongan.

52 Kendekmi kapadanganna, ri kapaan-paananna.

53 La randukmi mempangala', la tama kakajuanna.

54 Narombe-rombei bolo', natiantenni katimbang.

55 Nalempe-1empei baan, napesonno' sui lalong.

56 Anna tumetei batang, anna lamban lolok kau.

57 Sido'-sido' anna seba, sakkodo' anna pallea'.

58 Umbudai ri kollongna, unnalli ri penaanna.

59 Mataku'ri la nasanggang, lallenri la nabutai.

60 La napada'dua rara', la napa'tallu bulaan.

61 Polo balusu naumpu', $1 e^{\prime}$ to gallang siredean.

62 Disanga alukna Bugi', pasiruanna Balanda.

63 Dirundunan inaanna, dialan pa'poraianna.

54 katimbang: plant gelijkend op de Zengkuas, maar wat groter, die in het bos groeit, misschien Costus; de vruchten worden gegeten.

57 palzea', 1tl. degene, die voorbij schiet, bijnaam van de aap, omdat hij voorbij schiet aan hetgeen hij wil bespringen. 
47 De met snijwerk versierde prauw spreekt niet, het vaartuig praat niet.

48 Ik ben er verbaasd over, ik ben verbijsterd, wanneer ik er over denk.

49 Duizend prauwen volgen elkaar, zes honderd vertrekken tezamen.

50 Degenen, die zich in de rivier bevinden, trekken zich terug, de zoetwatervissen gaan ondersteboven.

51 Het wordt veroorzaakt door de met snijwerk versierde prauwen, zo wordt het gedaan door de schuitjes en de vaartuigen.

52 Het land rijst op, op hetgeen zichtbaar is.

$53 \mathrm{Zij}$ zullen in het bos gaan lopen, zij zullen het geboomte ingaan.

54 De bolo'-heester hangt als franje op hen neer, de katimbang-plant hangt neer op hen.

55 De parkieten kijken naar hen met scheef gehouden kopjes, de parkieten met rode borstjes gluren naar hen met naar achter gebogen 1 ijfjes.

56 Dan gaan zij de boomstammen op, zij lopen over de toppen der bomen.

57 Het scheelt weinig, of zij zijn als apen, bijna zijn zij als voorbijschieters.

$58 \mathrm{Zij}$ hechten de hoogste waarde aan hun leven, zij brengen offers voor hun levensduur.

$59 \mathrm{Zij}$ vrezen, dat $\mathrm{zij}$ hen kwaad zullen doen, $z i j$ zijn bang, dat $z i j$ hen blind zullen maken,

60 dat zij de halssieraden in tweeën zullen delen, en het goud in drieën.

$61 \mathrm{Zij}$ brengen de stukken van de armband van witte schelp bijeen, de stukken van de messing enkelring voegen zich gesmolten bijeen.

62 Het wordt de adatverrichting der Boeginezen genoemd, de wijze van doen der Hollanders.

63 Van het begin tot het einde worden hun gedachten gevolgd, hun wensen worden voor hen ingewilligd. 
64 Kumangnga-mangngai aku, pusakna' umpenaanni.

65 Sadio-diona mai, sauntangngana lalanna.

66 Ullambi' tondok 10'bang, banua kasao-sao.

67 Sao-saoanna donga, pendurukan bai ala'.

68 To mandasi' manna lan, to tumannun pori aak.

69 To mpodarun rangka'na, napobannang kanukunna.

70 Sadio-diona mai, sauntangngana lalanna.

71 U1lambi'mo pasa' datu, tammuan allo karaeng.

72 To mosaung manna lan, to motaro-taro manna.

73 To mpapada-pada manuk, to mpasitinti saungan,

74 Manuk matindo i pasa', manuk mamma' ri tammuan.

75 Pada matindo tadinna, pada mamma' pamulangna.

76 Pamulangna tungga' tedong, tadinna passaratusan.

77 Disanga alukna Bugi', pasiruanna Balanda.

78 Sadio-diona mai, sauntangngana lalanna.

79 Sae mengkanna i Suso, mengkaendek ri Te'tekan.

80 Tau lampung lan di Suso, to taan lan di Te'tekan.

66 kasao-sao, elders kasajo-sajo: hier en daar heen zweven.

72 mosaung: hanen laten vechten. Er komen slechts weinig vormen met het prefix mo- in het Sa'dan-Toradjaas voor; enkele daarvan zijn: motaro-taro in regel b, molisu en mokumungan in str. 126, en moasu: met honden jagen. 
64 Ik ben er verbaasd over, $i k$ ben verbijsterd, wanneer ik er aan denk.

$65 \mathrm{Zij}$ komen steeds meer hierheen, totdat zij halverwege zijn.

$66 \mathrm{Zij}$ bereiken een leeg dorp, een huis, waarin $z i j$ vrij hierheen en daarheen kunnen gaan.

67 De plaats waar de herten hierheen en daarheen gaan, de plaats waar de wilde varkens hun voedsel zoeken.

$68 \mathrm{Er}$ zijn slechts mensen in, die bezig zijn te naaien, lieden, die gordels weven.

69 Lieden, die hun vingers als naalden bezigen, hun nagels als garen gebruiken.

$70 \mathrm{Zij}$ komen steeds meer hierheen, totdat zij halverwege zijn.

$71 \mathrm{Zij}$ bereiken de markt van de god, de plaats van de ontmoeting bij dag met de heer.

$72 \mathrm{Er} z i j n$ slechts lieden in, die hanen laten vechten, slechts lieden, die geld inzetten bij het wedden.

73 Lieden, die opletten, of de hanen een gelijke partij zijn of niet, lieden, die vechthanen met elkaar vergelijken.

74 De hanen liggen op de markt, de hanen zijn gelegen op de plaats, waar men elkaar ontmoet.

75 Mede liggen er hun kunstsporen, mede zijn er gelegen de touwtjes, waarmee de kunstsporen worden aangebonden.

76 De touwtjes, waarmee $z i j$ worden aangebonden zijn op (de waarde van) éen karbouw te schatten, hun kunstsporen op een honderdtal.

77 Het wordt het adatgebruik der Boeginezen genoemd, de wijze van doen der Hollanders.

$78 \mathrm{Zij}$ komen steeds meer hierheen, totdat zij halverwege zijn.

$79 \mathrm{Zij}$ betreden Suso, zij stijgen op tot Te'tekan.

80 In Suso bevinden zich de bosmensen, in Te'tekan de zwervers.

79 Suso is een plaats in het complex Badjo', in het Palopose gelegen; Te'tekan ligt ten Noorden daarvan. 
$81 \mathrm{Ma}$ 'dinko kita disomba, dipangurande-randei.

82 Sadio-diona mai, sauntangngana lalanna.

83 Sae mengkanna i Se'ke', mengkaendek ri Sinadi.

84 Uai lolong ri Se'ke', sakke lempan ri Sinadi.

85 Napopedampi to Bugi', napotamba' to Balanda.

86 Anna masakke ara'na, mandarinding penaanna.

87 Ta 'pa passakkeko Bugi', bua uranko Balanda.

88 Sadio-diona mai, sauntangngana lalanna.

89 Sae mengkanna i Salu, mengkaendek ri Sangkuang.

90 To Salu indo'na bugi', to Salu kapoenanna.

91 Sadiong-diongna mai, sauntangngana lalanna.

92 Sae mengkanna i Mengka, mengkaendek ri Lolai.

93 Tabang kumombo i Mengka, umbalumbun di Lolai.

94 Kisape-sape daunna, kipelamba' baneranna.

95 Napopedampi to Bugi', napotamba' to Balanda.

96 Keden masaki ulunna, madaramban beluakna.

86 masakke, 1tl. "koel", bevat een zinspeling op het in str. 84 genoemde sakke, dat de $1 \mathrm{tl}$. betekenis heeft van: "koud water", vg1. ook passakke in str. 87.

87 passakke is een plant met rode bloemen en hagelvormige vruchtjes, welke als zegenbrengend bij verschillende offers dienst doet; de 1 tl. betekenis van het woord is: koelte gevend, heil brengend.

89 Salu is een streek in het complex Nonongan in Kesu'. Sangkuang, $1 t 1$. "een visvijver groot", is een parallelle benaming van Salu, omdat dit gebied beneden in het dal ingesloten is als ware het 
81 Moogt gij toch gehuldigd worden, moge hun een gave op de vlakke hand worden aangeboden.

$82 \mathrm{Zij}$ komen steeds meer hierheen, totdat zij halverwege zijn.

$83 \mathrm{Zij}$ betreden Se'ke', zij stijgen op naar de Sinadi.

84 Het water vloeit over Se'ke', de wateren stromen over de Sinadi.

85 De Boeginezen wenden het als geneesmiddel aan, de Hollanders gebruiken het als een bloedstelpend middel.

86 Opdat hun borst gezond $z i j$, hun adem afkoeling hebbe.

87 Moge gij, Boeginees land, gevestigd blijven als de heilrijke plant, moge gij, Holland, zijn als hagel.

$88 \mathrm{Zij}$ komen steeds meer hierheen, totdat zij halverwege zijn.

$89 \mathrm{Zij}$ betreden Salu, zij stijgen op tot Sangkuan.

90 De lieden van Salu zijn de moeders van de bugi'-riten, de lieden van Salu zijn hun verblijfplaatsen.

$91 \mathrm{Zij}$ komen steeds meer hierheen, totdat zij halverwege zijn.

$92 \mathrm{Zij}$ betreden Mengka, zij stijgen op tot Lolai.

93 De Dracaena is voortgesproten uit Mengka, $z i j$ is hoog opgeschoten in Lolai.

94 Wij trekken haar bladeren er van af, wij halen de bladeren er een voor een af.

95 De Boeginezen wenden het als geneesmiddel aan, de Hollanders gebruiken het als bloedstelpend middel.

96 Wanneer zij hoofdpijn hebben, wanneer zij een ziekte hebben in hun haar.

een visvijver.

90 kapoenan = kapuenan: plaats van oorsprong, verblijfplaats.

92 Mengka is een plaats in Lolai. Lolai is een complex van dorpen, die een eigen adatgemeenschap vormen, vaak het gebied van de kapala pitu: "de zeven dorpshoofden" geheten; het is een complex in het landschap Pangala' tegenover het Seseangebergte gelegen, aan de rechteroever van de Salusule (zie bij E Ib, 32).

96 madaramban $=$ madarambun $=$ marammun : ongesteld . 
97 Manoka didampi lemo, tae' disopai bangle.

98 Lolo tabang pedampinna, lassigi' pepamurru'na.

99 Anna masakke ara'na, madarinding penaanna.

100 Sadaa-daanna mai, sauntangngana lalanna.

101 La rampo indemo te, la tasik menggulilingmo.

102 Tondok boro toda inde, boro pangrantean toda.

103 Napa'bangunni banua, napa 'marongka-rongkai.

$104 \mathrm{Kau}$ asik napolentek, andelen napoa'riri.

105 Pio kalando petolo', kala'ka' tandi ianan.

106 Sali limbong tuda-tuda, gaang kumello pata'na.

107 Manangnga patakin gaang, bulaan roto rindingna.

$108 \mathrm{Ba}$ 'ba mata bulaanna, ampang pembassean seleng.

109 Petuo ra'pe busirrin, kaso manik dao mai.

110 Bulean napomanete, pio kalando tokeran.

111 Kiding-kiding tarampakna, bulaan roto papana.

98 parmurm' is ontstaan uit pamburru', een pa-afleiding van de geprenasaleerde stam van burm; pepamurm': hetgeen op iets geblazen wordt, het middel, dat op iets geblazen wordt.

104 asik: een boomsoort. andelen is een welriekend gras, dat bij sommige offers gebrand wordt.

106 tuda-tuda is een andere benaming van maa': oude katoenen tjindaidoeken.

107 "de openingen in de wanden", d.w.z. in het snijwerk van de wanden.

110 bulean = balian: blaasroer van zwart hout. 
97 Ze willen niet met limoen behandeld worden, ze willen niet met kalmoes bespuwd worden.

98 Jonge Dracaena-uitspruitsels zijn de medicijn er tegen, drakenbloedbladeren zijn het middel om het ermee te beblazen.

99 Opdat hun borst gezond $z i j$, hun adem afkoeling hebbe.

$100 \mathrm{Zij}$ komen steeds meer van het Noorden hierheen, totdat zij halverwege zijn.

$101 \mathrm{Zij}$ zullen dan hierheen komen, de zee zal rondom hen zijn.

102 Een liefelijk dorp is het toch wel hier, een liefelijk erf toch wel.

$103 \mathrm{Zij}$ richten er een huis op, zij leggen er een beplant terrein aan.

104 Als stijlen heeft het asik-hout, als midden-hoofdstij1 welriekend gras.

105 Lange lendengordels zijn de bamboelatjes, die zij door de stukken bamboedakbedekking steken, de vloerbalken zijn de onderlaag van de goederen.

106 De vloer is een verzameling oude weefsels, de beneden lengtebalk er van is een gebogen gouden kris.

107 Banden van gouden krissen zijn de brede stijlen aan de wanden, waarin de wandplaten geschoven worden, goud zijn de openingen in de wanden.

108 De deur is van het zuivere goud, de dwarsbalk van het deurkozijn is een lijn aan welke een seleng-weefsel is opgehangen.

109 De middenstijlen zijn oude doeken met mierenfiguren er in, de daksparren daar boven zijn kralen.

110 Als nokbalken heeft het blaasroeren van zwart hout, lange lendengordels zijn de bamboelatten, aan welke de latjes, waaraan de dakbedekking van bamboe geregen wordt, worden bevestigd.

111 De kleine stukken dakbedekking van de dakrand zijn kleine stukjes goud, die van de hoofdband van vrouwen op feesten gedragen ( $\left.s a^{\prime} p i^{\prime}\right)$ afhangen. 
112 Lotong boko' bubunganna, maa' mangimba longana.

113 Dapo' tamben bala tedong, lalikan sombo rongko'na.

114 Tang ruro rambu apinna, napa' torede-redei.

115 Kurinna batu lapparan, napantanakki bumbungan.

116 Rara' tibakka eranna, tangdo' pangalloan maa'.

117 Bendan kaluku issongna, alu tibuso bandangan.

118 Bingka' ditambane gallang, disa'pi' riti bulaan.

119 Mogo-mogo bai tora, doko sirante paladan.

120 Serre'opa to kulambi', kapu'na kampolo ponno.

121 Serre' annan palisunna, karua tanda-tandana.

122 Serre' matutu mangle'to, ia umponnoi baka.

123 Dibungka'i seleng manna, maa' mata puo manna.

124 Apaopa to muanga', natuntun lan inaammu.

125 Tedongomo to kulambi', sakean kukaratui.

126 Tedong molisu' i Mentang, mokurungan di Endekan.

127 Rokko dikambio santung, dika'bi' riti bulaan.

115 batu Zapparan, 1tl. schubben hebbend aan de poten, van vechthanen gezegd; dit heet een geluk aanbrengend teken te zijn.

122 mangle'to is een honorifieke benaming van het jongen krijgen van een kat; le'to is de soortnaam bij het tellen van de jongen van katten, tallung le'to: drie kattejongen; vgl. ook sile'to: broer en zuster van elkaar zijn (Sangalla').

125-131 zijn te vergelijken met The Chant, p. 53, IC, str. 87-90. 126 Mentang is een plaats in het Enrekangse. 
112 De nokbedekking is een oude doek, van welke de hoofdfiguur een buffel is met een zwarte rug, de schuin overhangende luifel is als een wapperend maa'-weefsel.

113 De haard is van kruiselings op elkaar gelegde balken als van een buffelstal, opvallend is het geluk der drie haardstenen.

114 De rook van het vuur er van blijft doorgaan, men blijft er steeds allerlei meel kokende houden.

115 Zijn kookpot heeft geluk aanduidende tekenen, men kookt er melk in.

$116 \mathrm{Zijn}$ trap bestaat uit halskettingen als treden, de voorgalerij er van is een droogplaats van oude weefsels.

117 Zijn rijstblok staat er als een kokospalm, de stamper schudt als een lans met geitehaar versierd.

118 De kleine wan heeft een rand rondom van geel koper, ze is omboord met een dunne gouden halsketting.

119 Week vanwege de vetheid zijn de varkens, wier slagtanden al lang zijn, de zeugen bevinden zich over het gehele erf verspreid.

120 Ook een kat nog tref ik aan, als bedekking van de korf vol sieraden.

121 Een kat met zes haarwervels, acht zijn haar kentekens.

122 Een kat die gedurig aan het jongen is, zij zorgt er voor, dat de grote korven vol zijn.

123 Slechts het seleng-weefsel wordt geopend, het oude weefsel met de figuren van kwartelogen er in slechts.

124 Wat dan nog zoekt gij, wat verlangt uw hart binnen in $u$ ?

125 Ik tref dan ook de buffels aan, ik kom aan bij hen, die bestegen worden.

126 De buffels komen uit Mentang vandaan, ze zijn in de kraal in Enrekang opgesloten.

127 Benedenwaarts wordt het snaarinstrument bespeeld, wordt getokkeld op de gouden snaren. 
128 Talo dondan diong mai, sipaela' kadakean.

129 Dolo pampang undi pampang, tarangga lan leu tangnga.

130 Tallu ratu' sangke'deran, sangsa'bu sangtiangkaran.

131 Anna ia to birangna, tedong tang mate anakna, tang masala sumanga'na.

132 Iapi anna mellao, anna tumengka i sulu'.

133 Apaopa to muanga', mutuntun lan inaammu?

134 Sanda nabenki' deata, pantan napatadoangki', ke sirundun deataki'. 
$128 \mathrm{Zij}$ lopen in kudden vlug voort, zij lopen langzaam met elkaar bij een afgrond.

129 De voorsten en de achtersten hebben recht gestrekte horens, die in het midden zijn, hebben recht omhoog gaande horens.

130 Driehonderd vertrekken er met elkaar, duizend maken zich op met elkaar.

131 En de wijfjes van hen, zijn buffels wier jongen niet sterven, hun levensgeest gaat niet onnuttig te loor.

132 ook niet, wanneer $z i j$ gaan, wanneer $z i j$ het hek van de stal uitgaan.

133 Wat dan nog zoekt gij, verlangt gij in uw hart?

134 Compleet alles geven ons de goden, ieder ding reiken $z i j$ ons toe, wanneer ieder het vraagt aan de betreffende god. 
H. van der Veen - 978-90-04-28716-7 Downloaded from Brill.come4/26/2023 02:54:12PM via free access 
TEKST G

\section{SINGGI' BUA' PADANG}

\section{Inleiding}

Evenals op het maro-feest een singgi': "lofprijzing" wordt aangeheven (zie E II), geschiedt dit tijdens het offerritueel van het bua' padang-feest, alsook op de grote dag van het bua' kasalle-ritueel.

Het bua' padang-ritueel wordt gevierd, voordat het nieuwe plantjaar van de rijst wordt ingezet. Een opvallende trek van dit ritueel is de bijzondere rol die de waringin inneemt, zie Crystal (December, 1973), 27. Het wordt ook Za'pa' padang genoemd, in het complex Riu van het landschap Tikala bua' pare, en in het landschap Ma'kale menani pare: de rijst bezingen. Men kan dit ritueel als het kleine landbouwnieuwjaarsfeest karakteriseren, het grote wordt bua' kasalle, la'pa' kasalle, of Za'pa' banua (vernieuwingsfeest van een bepaald huis uitgaande) genoemd.

Het woord bua' zal wel verwant zijn met het Indonesische buat: maken, doen, zoals ook het Indonesisch bekerdja de betekenis heeft van: aan het werk zijn, èn die van: een adatfeest vieren.

Een levendige beschrijving van het bua' padang-ritueel is te vinden in Crystal (December, 1973). Men zie ook C.A.M. Nooy-Palm (1975), p. 85 .

Het bua' padang-feest waarop men deze singgi' aanhief, werd gevierd in het landschap Piongan, een der berglandschappen ten Westen van Rantepao, het na Ma'kale grootste centrum van Tana Toradja.

op de grote dag van het ritueel werd een stellage opgericht op welke een to minaa, de kenner der offergeboden en adatinzettingen, de lofprijzing reciteerde onder het schudden van een bel. De singgi' vangt aan met een ode op de feestgever, wiens geboorte een bijzonder verloop had. Hij is een telg uit een geslacht, dat uit de bovenwereld was neergedaald, evenals de van ouds overgeleverde adatvoorschriften. $\mathrm{Hij}$ is anders dan de andere mensen, al van de oorsprong af. Hij is het op wien het landschap Kesu' steunt (str. 1-54).

Nadat de adatinzettingen verdeeld en de adatregelingen bepaald waren, werd de adatgemeenschap in alle geledingen gezegend en bloeide de welvaart op (str. 55-61). 
Tekst

Diong sando siura'ku.

La kuparokkoi nani!

1 La kukarrangrika nani,

la kupakataku'rika?

2 Turiangna gandang langi', bombongna to palullungan.

3 Silasanna naposugi', patunna napolulangngan.

4 Anna tang disirantean, naala tonglona sugi'.

5 Kadadiannamo ia, randuk dipangidenanni.

6 Minda la susi ambana, la ten pa'kaleanna.

7 Tang nauma ke marangke, ke sitangkeki' pekali.

8 Iapi anna umai, kalimbuangpi randanna.

9 Bubunpi tiku-tikunna, natalimbung tama limbong,

10 doke-dokepi riunna, anna pamenta siroro -

11 ia palopona uma, anna ambollong sitanduk -,

12 iapi rumpang umanna, diong kiru-kiru toding, anna lendong balo ajak.

1 siura' is een afleiding van ura': geluk hebben met; het heeft de betekenis: geschikt voor elkaar zijn om geluk te hebben.

2 Met de uitdrukkingen "de trommen van de hemel" en "de gongs van he al omhullende" worden meestal de to minaa aangeduid. Hier is het d honorifieke betiteling van de aanzienlijke, machtige man, de toeverlaat van het gebied van Kesu'.

palulzungan: "het al omhullende" is een dichterlijke uitdrukking voor "uitspanse1".

10 doke-doke: een slecht riekende waterplant, die op sawahs groeit; pamenta: een fijne grassoort, misschien Oplismenus Burmannii. 
Vertaling

Hier beneden is mijn vertrouwde vriend met wie ik geluk heb. Laat ik de lofzang op hem doen neerdalen.

1 Zou ik de lofzang op strenge, vrees aanjagende wijze ten gehore brengen, zou ik hem angst doen inboezemen?

2 De luisterrijke van de trommen van de hemel, de gong van het uitspansel.

3 Het matige is hem tot rijkdom, het gepaste doet hem omhoog stijgen.

4 Zodat hij niet geëvenaard wordt, hij de hoogste trap van rijkdom bereikt heeft.

5 Zijn geboorte dan nu, begon, dat de lusten voor hem werden opgewekt.

6 Wie was er krachtig als hij, wie had een gestalte als hij?

7 Wanneer het droge grond was, legde hij er geen sawah aan, wanneer wij er een graafstok voor moeten hanteren.

8 Dan pas legde hij een sawah aan, wanneer er een wel aan de rand was.

9 Wanneer er rondom bronnen waren, en het water samenkwam in een waterplas,

10 wanneer het gras er van doke-doke planten was, wanneer de fijne grassoort er omheen kroop -

11 het waren zeer vette sawahs, zodat de combolzong-planten er elkaar raakten -,

12 dan pas waren er allerlei soorten vis, waren er de platte sawahvissen met een wit vlekje op de kop, en de gestreepte aaltjes.

11 ambolzong is een sawahplant met paarsachtige bloemen, welke als groente en als varkensvoer gebruikt wordt. sitanduk, 1tl. elkaar stoten met de horens.

12 rumpang uma, 1t1. het vuilnis van de sawah. 
13 Diong sando siura'ku.

Inde la susi ambana,

la ten pa'kaleanna?

$14 \mathrm{Ke}$ lu rekke,

ke lu sau'.

15 Sesean pa'demo daja,

Sado'ko' tae'mo ditiro.

16 Nasarombon penanna, natuli rambu bottokna.

17 Tang narendenna' manii, tang kanna masae lako.

18 Untiko-tiko ambe'ku, tang ungkamu ma'dadingku.

19 Inang tennamo lako, to ke kendek inde enda',

20 inde gorang bulananna, tando' lepongna deata.

21 Sirondong sendana sugi', na pare mellao langi'.

22 Urrundunan aluk nene', bisaranna to dolota.

$23 \mathrm{Tu}$ aluk mellao langi', sangka' turun dibintoen.

24 Tang talambi' manii lako, tang takaratui lenni, anta tang kebala kollong.

25 Tang mutiroraka lako, tang ta'paraka matammu, tae'ka pessailemu?

26 La kulambi'mi dadinna, la kudete' garaganna.

27 Ia ade' tonna dikombong, randuk dipangidenanni,

19 enda': "trap" is een nevenvorm van eran.

21 sendana sugi": "de rijke tjendanaboom" = sendana bonga: "de bonte tjendanaboom" is een witgespikkelde tjendanaboom, die een roodachtig kernhout heeft. Deze boom wordt op de grote offerfeesten aan de goden, het merok-feest en het bua' kasalle-feest, geplant aan de ingang van het dorp, zie The Merok Feast, p. 21, noot bij B, str. 15. 
13 Hier beneden is mijn vertrouwde vriend met wie ik geluk heb. Wie is er krachtig als hij, wie heeft een gestalte als hij?

14 Wanneer men stroomopwaarts, wanneer men stroomafwaarts gaat,

15 dan verdwijnt de Sesean in het Noorden, de Sado'ko' wordt niet meer gezien.

$16 \mathrm{Zijn}$ geest stuift weg, de rook stuift tegen zijn kruin op en sleurt die mee.

17 Het mocht mij eens niet wel gaan, ik mocht eens niet meer zo'n lange duur van leven hebben.

18 Wanneer ik mijn vader zou tutoyeren, en geen $u$ zou zeggen tegen hem, die mij verwekte.

19 Voorzeker nu het hierheen gaat, nu deze trap gaat oprijzen,

20 is hier hun gouden platform, de ronde verhevenheid der goden.

21 Dicht bij de rijke tjendanaboom, en de rijst, die uit de hemel neerdaalde.

22 De adatvoorschriften der voorouders volgend, de adatregelingen der voorouders.

23 De adatvoorschriften, die uit de hemel zijn neergedaald, de inzettingen, die van de sterren zijn neergekomen.

24 Wanneer wij hen niet mochten bereiken, wanneer wij nooit tot hen mochten reiken, dan zouden wij geen bescherming hebben tegen onheil of vloek.

25 Hebt gij het niet opgemerkt, hebt gij het niet in het oog gehad, hebt gij er niet naar omgezien?

26 Laat ik tot zijn geboorte gekomen zijn, zijn vorming bereikt hebben.

27 Toen hij dan, naar men zegt, geformeerd werd, toen hij gebaard zou worden,

24 bala kollong, 1tl. "omheining om de hals", een overdrachtelijke uitdrukking met de betekenis van: "hetgeen ons tegen onheil of vloek beschermt", bv. bepaalde offers en riten.

25 tang ta'paraka matammu?, 1t1。 heeft uw oog er niet op gerust? $26 \mathrm{v}$. vgl. The Chant, p. 47 , IC, str. $8 \mathrm{vv}$. 
28 tang dikandean essun, tang dileran bua kaju,

29 rokko dikokoang bendo, dialan tallu buaja.

30 Ia nakande indo'na, ia nakasumanga'i.

31 Bulaan manna nakande, rara' nakasumanga'i.

32 Nadadianni indo'na randukmi natibussanan.

33 Saemi mantanan toni, unnosok rambo-rambona.

34 Sitangke pekali bassi, sumarromi to keengkok.

35 Mekaindo' to kebali'bi', disu'be' pekali bassi, dinii untanan tauninna.

36 Inda 1a susi ambana, la ten pa'kaleanna?

37 Ke lu rekke, ke lu sau'.

38 Bulaan natibusanni, rara' nakusamanga'i.

39 Tedongna umbolong lombok, ungkalembangi tanete.

40 Inang senga' ke to senga', ke nang tempon ioto'na.

41 Ia parandena Kesu', ia tandinna Bangkudu.

42 Peassa'na Bualajuk, pangalan mamma'na ia.

43 Anna siosso'i sugi', nasituran-turananni.

28 heeft de betekenis, dat de lusten van zijn moeder, toen zij zwanger was van hem, niet uitgingen naar het zure en naar vruchten.

29 De notabele en rijke man, wien de lofprijzing geldt, had een buitengewone geboorte; zijn moeder had in haar zwangerschap allerlei gegeten, dat een bovenmenselijke, vervaarlijke kracht had.

33 rombo-rambo, 1t1. vezels, franjes.

35 mekaindo', itl. de kreet o indo'! (d.i. "o moeder!") slaken. 
28 werd voor hem het zure niet gegeten, werden voor hem geen vruchten gesmaakt,

29 stak men voor haar de hand in een nauwte uit naar een riviermonster, werden krokodilleëieren voor haar gehaald.

30 Die at zijn moeder, daar gingen haar lusten naar uit.

31 Goud slechts at $z i j$, naar een halssieraad met goud belegd gingen haar zinnen uit.

32 zijn moeder baarde hem, ze deed hem uitkomen uit de moederschoot.

33 Men kwam de nageboorte begraven, men stopte de placenta in de grond.

34 Men hanteerde er een ijzeren graafstok bij, de lieden in de benedenwereld zuchtten er van.

35 De lieden in het onderaardse riepen ach en wee, toen de ijzeren graafstok er in gestoken werd, op de plaats, waar zijn nageboorte begraven werd.

36 Wie zou er krachtig zijn als hij, wie zou er een gestalte hebben als hij?

37 Wanneer men stroomopwaarts, wanneer men stroomafwaarts gaat.

38 Door goud (tot zich te nemen) deed zij hem uitkomen uit de moederschoot, naar een halssieraad met goud belegd waren haar zinnen uitgegaan.

39 Zijn buffels maken het dal zwart, doen het gebergte tot een harde, kleiachtige massa zijn voor het gezicht.

40 Voorzeker hij is anders dan de andere mensen, zeker al van de oorsprong af.

$41 \mathrm{Hij}$ is het, die Kesu' op de handen draagt, hij schraagt Bangkudu.

42 De steunbalk van Bualajuk, hetgeen hij al in zijn dromen in de slaap ontvangen heeft.

43 Zo is het, dat hij rijk is van geslacht op geslacht, van generatie op generatie. 
44 Moka ia tu la tallan,

la natuka' tau senga',

45 tu bela nasiosso'i, nasituran-turananni.

46 Noka ia rato bombongna,

la tallan menggulasingna.

47 To inang kampai to'na, tang ma'din natuka' tau.

48 Nene'na mellao langi', sola turan to dolona.

49 Sae mengkanna i Buntu, mentunannang ri Lellua.

50 Rampo 10' bambana Lembong, pessulunanna Malino.

51 Nene'na Ne' Tangdilino', rampo dao bamba Marinding.

52 Undadiammi Pabane', untirandukkimi Balenga,

53 to dao bambana Gandang, umpatuka' pa'ba'tengan, umpasolo' pa'inaan.

54 Untirandukki bambana Kesu', pessulunanna Beloara'.

55 Dadi to sanda karua, kombong ganna' bilanganna.

56 Randukmi mantaa aluk, ussio' pananda bisara.

57 Randukmi paria tannun, urria sanda menaa,

58 urria tetean tampo, sola to sanda rangka'na, na to pantan tarunona,

44 Naast de meer gebruikelijke vorm noka komt ook de vorm moka voor.

46 Deze strofe betekent: hij zou niet willen, dat zijn rijkdom zou te niet gaan.

52 Balenga: naam van een vestiging in het dorp Tadongkon in het landschap Kesu'.

53 Gandang: naam van een vestiging in het dorp Tadongkon nabij de tongkonan Buntu Kalando. 
$44 \mathrm{Hij}$ wil niet, dat hij zou zinken, dat anderen hem zouden vervangen,

45 die het aankunnen van geslacht op geslacht, van generatie op generatie.

$46 \mathrm{Hij}$ zou niet willen, dat de nerf van zijn pisangblad te niet zou gaan, zijn spruiten zouden afsterven.

$47 \mathrm{Hij}$ is voorzeker iemand, die zijn afkomst behoedt, het is niet mogelijk, dat anderen hem zouden vervangen.

$48 \mathrm{Zijn}$ voorvaderen daalden van de hemel neer, en het geslacht zijner voorouders.

$49 \mathrm{Zij}$ kwamen aan in Buntu, $z i j$ vestigden $z i c h$ in Lellua.

$50 \mathrm{Zij}$ kwamen aan in het Zuiden in het gebied van Lembong, in het oord van Malino.

51 Zijn voorvader Ne' Tangdilino', kwam aan in het gebied van Marinding.

$52 \mathrm{Hij}$ verwekte Pabane', die begon zich te vestigen in Balenga,

53 in de hoogte van het gebied van Gandang, hij verhief zijn innerlijk in de hoogte, hij deed zijn gedachten neerdalen.

$54 \mathrm{Hij}$ begon zich te vestigen in het gebied van Kesu', in het oord van Beloara'.

55 Toen werd het volledige achttal geboren, toen kwam het complete aantal in het aanzijn.

56 Men ving aan de adatinzettingen te verdelen, het bepalen van de adatregelingen.

57 Toen nam het zegen-aanbrengende een aanvang, koesterende al wat adem heeft,

58 koesterend het betreden van de sawahdijken, al wat gevingerte heeft en al wat vingers heeft,

57 paria tannun, 1t1. het kon het weefsel op de schoot houden.

58 to sanda rangka'na, 1t1. compleet alles wat gevingerte heeft; to pantan tarunona, 1t1. al hetgeen vingers heeft. 
59 urria ma'bala tedong, urria pangkungna bai,

60 uainna ta'gena lentek, urria bujanna manuk.

61 Angganna ianan sanda makamban, i amo napa'parandangan. 
De lofprijzing t.g.v. het bua' padang-feest (G, 59-61)

59 koesterend het stallen der buffels, koesterend de varkenshokken,

60 het verzorgen der varkens, koesterend het op stok zitten der hoenders.

61 Alle bezittingen tezamen in menigte, die hebben hen als grondslag. 
H. van der Veen - 978-90-04-28716-7 Downloaded from Brill.come4/26/2023 02:54:12PM via free access 
De hier bijeengebrachte singgi'-teksten worden gereciteerd op de grote dag van het bua' kasalle-feest, dat op de kala'paran, de feestplaats buiten het dorp, plaats heeft. Een beschrijving van dit feest is te vinden in J. Kruyt (1921), 161-167; vgl. ook C.A.M. Nooy-Palm (1975), 84.

Dit feest schijnt het oudste feest van de adatgemeenschap der To Sa'dan te zijn. In de overlevering wordt gewag gemaakt van een bua'feest, dat aan het slot in de cyclus van feesten dienst doet om heil voor de hele adatgemeenschap af te smeken, nadat verschillende zoenoffers gebracht zijn. Er schijnen wel enige reinigingsoffers aan dat feest vooraf te zijn gegaan. In die overlevering komt de figuur van de burake, de priesteres die de hoofdleiding van het feest heeft, nog niet voor. Evenmin wordt er in de oudste overleveringen gerept van een maro-ritueel als voorbereiding op het bua'-feest.

In de badong-zang, gezongen bij het dodenritueel dat volgens de regels van het dirapa'i (vgl. The Chant, p. 2) gevierd wordt, heet het dat de eerste voorvader het oudste voorvaderhuis oprichtte in het uitspansel, daar het bua' kasazle-feest vierde, op het eiland Pongko neerdaalde, naar het vasteland overstak en een voorvaderhuis oprichtte. Op die tocht ging zijn to burake (er wordt niet bij vermeld of dit een to burake tattiku' of een to burake tambolang was, waarschijnlijk een van de eerste kategorie) voor hem uit, haar geratung-trom (een kleine trom, waarover door middel van een koord met kralen een python-vel gespannen is) schuddende. Enige malen werd dat voorvaderhuis weer verplaatst en ging de to burake voor de voorvader uit (vgl. The Chant, p. 20-28, IA, str. 17-107).

In het Bambangse heet het bua' kasalle-feest pa'bisuan. Naar de verklaring die N. Adriani in V.G. II, 195v. van het Boeginese woord bisu geeft, nl. zich onthouden, speciaal van het huwelijk, zou men pa'bisuan het ritueel der zich onthoudenden kunnen noemen. Het woord bisu zelf komt in het Sa'dans niet voor, maar wel de nevenvorm bingsu, die o.a. wordt aangetroffen in The Merok Feast, p. 146, B, str. 755, waar bingsu mapato, "priesteres met bovennatuurlijke kracht", parallel is met burake manakka. (Het woord bingsu is een vorm met ingeschoven 
nasaal van bisu, zoals tangsu van tassu: ergens uitgaan.)

Op een bepaalde dag van het pa'bisuan-ritueel wordt een grauwe buffel geslacht en een groot aantal varkens, afhangende van het aantal to malangi'. Deze to malangi' gaan verblijf houden in een versierde waringin-boom; zij zijn te vergelijken met de to tumbang van het bua' kasalle-feest in de landschappen van het Sa'dan-gebied: oudere of jongere vrouwen, onderworpen aan verschillende verbodsbepalingen, die gedurende het feest in taboe-toestand moeten vertoeven in het huis vanwaaruit het feest wordt gevierd en tegen het einde ervan in een hut in een waringin-boom verblijf moeten houden. (Voor to malangi', to tumbang en overeenkomstige termen zie tekst E Ia, Inleiding.)

Op de feestplaats waar men het bua' kasalle-feest viert is een platform (gorang) opgericht, rustende op zes palen. De gorang is een sacrale plaats, die de verbinding met de bovenwereld vormt en waarop men zich daarom met ontzag beweegt. Nadat men in een stoet enige malen om de gorang is geschreden, beklimmen twee to minaa dat platform. Ze zijn door een lange doek, pangriu, verbonden met de personen over welke zij de lofprijzingen, singgi', zullen uitspreken. De aanzienlijke lieden, die het feest aanrichtten, ampu bua' geheten, worden met een lange lofprijzing bedacht en de afstammelingen van de helden, die vroeger er op uittrokken om een mensenhoofd te bemachtigen, ontvangen een bijzonder lange lofprijzing, vgl. H III. 


\section{SINGGI' TONDOK (H I)}

Inleiding

Deze "lofzang op de gemeenschap van dorpen" tekent welvarende dorpen met een menigte hoenders, diverse vruchtbomen, door waterrijke sawahs omringd, met een talrijke kudde buffels van grote waarde en een achttal tegenover elkaar staande rijstschuren.

De raad der notabele vrouwen is, dat men de rijst aan de zijkant van de rijstschuur opgeslagen moet gaan verkopen op de markt. Er is zoveel rijst, dat men er wel een jonge buffel, maa'-weefsels en patola- en sarita-doeken voor zou kunnen kopen (str. 36-43). Zij rijgen slechts kostbare, geselecteerde kralen (str. 47-50).

Het smeden van zwaarden, van hakmessen en schopjes wordt uitvoerig beschreven (str. 54vv.). 
Tekst

1 Tondok mariri litakna, kemasak pellaoanna, tinggi ongan banuanna.

2 Tondok tipassare gajang, tipalili' bulu londong.

3 Sumomba pempaja allo, dipa'bangunni banua.

4 Diosok salle a'riri, tondok pa'buntuan sugi'.

5 Natalimbung kalalunan, naapun lellua langngan.

6 Tu rongko' patalo dio, sitondon tindo bonginna, sola mamma' karoenna.

7 Ma'liku-liku tondokna, tasik pollo' banuanna.

8 Orong-oronganna tedong, pessimbonganna kanae.

9 Manuknaraka 1a tae', mabaanan anna bekak.

10 Dikki' anna surusiak, langngan ungkapai lamba'.

11 Tang umpasombo barana' . misa'ri ma'laen dadi.

12 Susi londongna Lapandek, manukna Tulangdidi'.

1 tondok: kampong, dorp heeft in dit verband de ruimere betekenis van gemeenschap van dorpen binnen welke het $2 a^{\prime} p a^{\prime}$-feest gevierd wordt. masak zijn donkergele kralen van grote waarde.

2 tipassare gajang, 1t1. aangeleund tegen gouden krissen.

3 sumomba, $1 \mathrm{tl}$. hulde bewijzen; dan: verschijnen voor, zich richten naar.

Met pempaja alzo: het paradijsvogelveren-versiersel van de zon, wordt het Oosten bedoeld; deze uitdrukking slaat op de dorpen tegen het Mamullu-gebergte gelegen, die hun front hebben naar het Oosten, t.w. de dorpen vanaf Kadundung in het Zuiden tot aan 
Vertaling

1 Gemeenschap van dorpen met gele aarde, hun erven zijn bezet met masak-kralen, donkerrode kralen zijn de schaduwplekken van hun huizen.

2 Dorpen, waar gouden krissen omheen zijn gesteld, omgrensd met haneveren.

3 Gericht naar het paradijsvogelveren-sieraad van de zon, werden er huizen opgericht.

$4 \mathrm{Er}$ werden grote stijlen in de grond gezet, dorpen van degenen, wier rijkdom is als een gebergte.

$5 \mathrm{Ze}$ zijn rondom omgeven door hetgeen zich hoog verheft, omringd door hetgeen hoog uitsteekt.

6 Het geluk heeft er de overhand, beantwoordend aan de nachtelijke dromen, en de slaap in de vooravond.

7 Hun dorpen zijn vol plassen, de achterzijde van hun huizen is een zee.

8 De plaats, waarin de buffels zwemmen, de plaats, waarin de karbouwen plonzen.

9 Zouden hun hoenders er niet zijn? Ze zijn er in zwermen meer dan de kaketoes.

10 Meer dan de vogels met velerlei geluiden, vliegen ze op en doen de takken van de ficus-bomen slap neerhangen.

$11 \mathrm{Zij}$ maken, dat de waringin niet zichtbaar is, zij zijn enig in hun bijzondere positie.

12 Als de Haan van Lapandek, het Hoen van Pong Tulangdidi'.

Sereale in het Noorden. Angin-Angin tot en met Limbu, die tegen de helling van het Sarira-rotsgebergte gelegen zijn, zijn naar het Westen gericht met hun front.

7 ma'liku-liku, 1tl. vol diepe plaatsen, vol kolken, d.i. vanwege de menigte van buffels, die zich daarin bevinden.

12 Deze regels noemen de namen van een wonderhaan, die allerlei te voorschijn wist te toveren; deze haan werd door Pong Tulangdidi' geslagen en vloog toen de lucht in; hij moet aan de maan hangen volgens de overlevering, zie Van der Veen (1924), 63-70. De twee eigennamen duiden mythische figuren aan. 
$13 \mathrm{Ma}$ 'kukkua sae tedong, unnoni ratu kanae.

14 Kotok renden penamile, mengkaro bu'tu bulaan.

15 Karondang mesora pindan, dambu meti'doan alo.

16 Sitoko-tokoan punti, silolinan lau saa.

17 Dua'na sisama tengko, tang napura pia ro'son, bokko' umpakamangkai.

18 Tang nauma ke marangke, manggi' naruranni kalo', natalimbung bubun issong.

19 Saruran tiku randanna, salakka' manna pariu, da'dak manna ummangkai uma.

20 Tedongomo dipokada, tedong ma'rapu i Letta'.

21 Rokko dikambio pangka, dika'bi' pa'pairusan.

22 Anna ke'de' diong mai, anna lao sambalin mai.

$23 \mathrm{Bu}^{\prime}$ tu lamban dio mai misa' bulan napadolo.

24 Tanda pasangnara tondo, na baliang da nasae, na rokkok nasule sau'.

25 Dolo pampang, undi pampang, bonga umatai lalan.

26 La rampo indete tondok, ratu indete pangleon.

15 De karondang is een boom met ronde, zure vruchten, die veel pitjes bevatten; ze zijn wat groter dan druiven, Flacourtia inermis.

19 salakka' = da'dak: een bamboekorf, die van boven een smalle hals heeft en naar beneden wijd uitloopt met scherpe punten van onderen; men duwt die korf in de sawahgrond, vangt op die manier vis en woelt de grond om.

20 Letta' is een rijkje ten Noorden van Pinrang.

21 De str. 21-29 bevatten verschillende typeringen als in The Chant, p. 53v., IC, str. 87-98. 
13 Hij kraaide, toen kwamen er buffels, hij gaf geluid, toen verschenen er karbouwen.

$14 \mathrm{Hij}$ kakelde en trok toen buffels voort, hij klauwde, toen verscheen er goud.

15 Karondang-vruchten waren er van verschillende kleuren, zoals de bloemfiguren op borden van aardewerk, roze appelvruchten, die deden watertanden.

16 De trossen pisangs bogen zich naar elkaar toe, de als het vel van de pythonslang kleurig gestreepte pompoenen rolden tegen elkaar aan.

17 Hun knollen waren even groot als een ploeg, de flink opgeschoten kinderen kregen ze niet op, de kleine kinderen makten ze op.

$18 \mathrm{Zij}$ legden geen sawah aan op droge grond, er moest een greppel zijn, die er water over heen liet lopen, hij moest omringd zijn door wellen, omsloten door wanden van gehouwen steen, rond als een stenen rijstblok.

19 Aan de kanten moest een waterleiding zijn rondom, een bamboekorf slechts was nodig om ze van gras te zuiveren, een bamboekorf slechts bracht de sawah geheel in orde.

20 Er wordt dan nu over de buffels gesproken, de buffels waren in een kudde in Letta'.

21 Men daalt af en wenkt hen met een juk om er een buffel in te spannen, men wenkt ze naar de drinkplaats.

$22 \mathrm{Zij}$ maken zich op van daar, zij vertrekken van gene kant.

23 overgestoken verschijnen zij van daar, een albino laat men voorop lopen.

$24 \mathrm{Hij}$ is het teken van hun weideplaats, en een buffel, die slechts aan éên zijde haarwervels heeft, mag niet komen, een buffel met een haarwervel aan de kop tussen de oren laat hij Zuidwaarts terugkeren.

25 De eerste zijn buffels met dwars uitgestrekte horens, de laatste zijn buffels met dwars uitgestrekte horens, de buffel met een bles houdt de weg in het oog.

26 Ze zijn van zins hier in het dorp aan te komen, de nederzettingen hier te bereiken. 
27 Sae dipotulak bala, ditodingan sulu' tedong.

28 Tedong tang mate anakna, tang masala sumanga'na.

29 Iapi anna mellao, anna tibasse i sulu', tampang rurapi nanai.

30 Alangnaraka la tae'? Sitongaan tiku landa'na.

31 Bendan alang karuanna, dipa'parampoi sae.

32 Dipa'baen-baenanni, disissing timbu mariri, dipatimba' pia'-pia'.

33 Nakua kadanna datte', randan pudukna mandoti.

34 "Kimetambingmora kami, kimesongi-songimora.

35 Kande redekna to sae, mairi' to umbaa tedong."

36 Tu bulaan banne ba'tang, tu rara' rangga inaja, ponto passasaran tuju.

37 Nakua kadanna rara', randan pudukna bulaan:

38 "Pa'tammuan panitoko, pa'pasa' sa'de alangko."

39 Pare manoka didaja, tang ma'din dikira-kira.

40 Iapi anna mellao, anna leak dipanito,

27 ditodingan: een teken geven met het bloed van het offerdier op het voorhoofd en de wangen van de deelnemers aan een merok- of bua' kasalle-feest.

29 tibasse, 1t1. aan het afdalen zijn.

33 mandoti: soort langharige kleefrijst, die donkerbruin van kleur is. pare datte' is een rijstsoort met rode huid, de ene soort is kleefrijst, de andere niet.

34 songi-songi = tambing: een aanbouwsel aan de zijkant van een huis of rijstschuur. 
$27 \mathrm{Zij}$ komen aan en dienen als stut voor de stal, de grendel van de buffelstal wordt voorspoedig geacht.

28 Buffels, wier jongen niet sterven, wier levenskracht niet vergaat.

29 Dan slechts gaan zij, gaan zij de afsluiting van de stal uit, om te verblijven bij een grote sawah, die steeds vol water staat.

30 Zouden ze geen rijstschuren bezitten? Rondom staan hun rijstschuren tegenover elkaar.

31 Hun acht rijstschuren stonden er, de plaats om hetgeen aangedragen wordt op te slaan.

32 Het wordt er mee zwaaiend in gebracht, het wordt er propvol met het gele als een bron goed dicht gestopt, het wordt er in gestopt, zoals hapjes in de mond van kleine

kinderen.

33 De woorden van de rijst met rode huid luiden, de rand der lippen van de kleefrijst uit zich als volgt:

34 "Laten wij een bergplaatsje maken aangebouwd aan de rijstschuur, laten wij een bergplaatsje maken buiten de rijstschuur.

35 Het voedsel zo nu en dan voor de gasten, voor allen, die buffels brengen."

36 De edele vrouwen zijn afstammelingen van mensen met een goed verstand, de edele vrouwen hebben veelsoortige gedachten, de voorname vrouwen zijn rijk aan goede raad.

37 De woorden van de gouden halssieraden luiden, de rand der lippen van het goud uit zich als volgt:

38 "Houd markt, kleine omwande ruimte naast de rijstschuur, richt een pasar op, gij zijkant van de rijstschuur."

39 De rijst wil niet misleid worden, $z i j$ kan niet bedrogen worden.

40 Dan pas gaat zij naar beneden, gaat ze over het vloertje vobr het deurtje van de rijstschuur heen,

36 banne ba'tang, 1tl. het zaad van het binnenste; overdrachtelijk: mensen met een goed verstand. passasaran tuju, 1tl. waar men biezen (Fimbristylis globulosa Kth) van afgesneden heeft; deze woorden geven vaak voorname lieden te kennen, die vanwege hun positie goede raad weten te geven.

40 panito, vloertje aan de voorzijde van de rijstschuur; daarop is gezeten degene, die de bossen rijst uit de schuur haalt. 
41 mentingarapi langgesa', lenga'pi lundara'-dara'.

42 Lendu' maa' tang nabengan, patola nakamisai.

43 Kombong sarita onona, sola baluk-balukanna.

44 Tu bulaan banne ba'tang, tu rara' rangga inaja.

45 Lessu' paduk tang natoe, tibambang natiro-tiro.

46 Iapi anna mentoe, anna tikambe 1 imanna.

47 Barra' manikpi natolo', tinggipi naseno pala'.

48 Napilei madatunna, natonno' makaraengna.

49 Napopembasse dikollong, napatama dibaroko.

50 Anna matotau la'bi', inang to tanggana-gana.

51 Bassimo dilambi' to, batu tongkon lan di tasik disiriang-rianganni disikanoto-notoi.

52 Dila'bak sisama rirding, ia ma'usuk pinamile.

41 De betekenis van deze strofe is, dat de rijst in grote hoeveelheden verkocht wordt tegen de prijs van een jonge buffel of een wijfjes buffel, die nog niet gejongd heeft.

43 De bedoeling hiervan is, dat men voor die rijstkorrels nog saritaweefsels kan kopen.

45 De zin van deze strofe is, dat ze hun handen niet willen uitsteken voor een werkje, dat beneden hun waardigheid is.

47 barra' manik, 1t1. kralen als ontbolsterde rijstkorrels.

51 De overeindstaande steen zou volgens de Heer Tammu het ijzeren aambeeld kunnen zijn. Het heet gemaakte ijzer wordt afwisselend door twee mannen geslagen om het te pletten. Dit afwisselend beklopt worden wordt gezegd van het bewerken van het ijzererts in de oude tijd.

disiriang-rianganni: er wordt steeds afwisselen op geklopt. 
41 wanneer eerst de jonge buffel er een blik opwaarts op geworpen heeft, een nog niet gejongd hebbende wijfjesbuffel eerst nog aan het herkauwen geweest is.

$42 \mathrm{Maa}^{\prime}$-weefsels waarmee men langs komt laten ze niet toe, dat anderen die krijgen,

de patola-doeken willen ze allen voor zich in bezit hebben.

43 Uit de rijstkorrels, die uit de aren gevallen zijn bij het bergen in de schuur, komen nog sarita-weefsels voort,

te zamen met de rijstkorrels, die uit de aren gevallen zijn van de rijstbossen, die verkocht worden.

44 De edele vrouwen zijn afstammelingen van mensen met een goed verstand,

de voorname vrouwen hebben veelsoortige gedachten.

45 Wanneer de bamboekoker, die als drinkgerei dienst doet, uitglijdt, pakken ze die niet, wanneer ze neergeworpen is, blijven ze er naar kijken.

46 Dan pas grijpen ze er naar, wanneer hun handen zijn uitgestoken.

47 Slechts wanneer het fijne kralen zijn, rijgen zij ze, slechts wanneer het donkerrode kralen zijn, die gezeefd zijn op de handpalm.

$48 \mathrm{Zij}$ zoeken de kostbare er uit,

zij kiezen de edele er uit.

49 zij laten ze zich om de nek hangen,

zij doen ze om de hals.

50 Zodat zij er uitzien als voorname lieden, zeker lieden van hoge stand.

51 We zijn nu aan het ijzer toegekomen, de overeind staande steen in de zee, waarop steeds maar afwisselend geklopt wordt met een hamer, men slaat er afwisselend goed raak op.

52 Het wordt afgeschilferd als de beschotstukken van een wand, het is als de ribben van een grote buffelstier. 
53 To matua dilantangan, to moleng digaru'gasan.

54 Umpabendan tau dua, umpasisulle nalunte, napasibunte-buntean.

55 Kukalle-kallei aku, pusa'na' umpenajanni, umbarang tang paissanni.

56 Ussulingan sae angin, umpopa'tete darinding.

57 Unnoni lalliu langi'.

58 Susi gandang sarapian, pare lotong kinandena.

59 Sola bo'bo' bongi-bongi, nasurrukan maleulung.

60 Nabua' ten danga-danga, lendong manangke natoe.

61 Umbenga' sangdadianna, nabungga-bungga pebusuk.

62 Sarombon susi luppepe', male bia' marorrongan, nabeloi sia daa.

63 Kukalle-kallei aku, pusa'na' umpenajanni, umbarang tang paissanni.

64 Sirondong asu busa'na.

65 Nasapu-sapu sokko'na.

66 Natarek ten bulu londong, nalipu-lipu naujun.

53 Volgens de Heer Tammu is de betekenis van "de ouden" hier het aambeeld, waarvoor een loodsje wordt gemaakt; "de holen voor de heel ouden" zou op de blaasbalg voor de smeden kunnen doelen. digaru'gasan: er worden holen voor gemaakt.

54 umpabendan tau dua, 1tl. men stelt twee lieden op; de blaasbalg wordt zo genoemd, omdat ze twee balgen heeft; in d.t. heeft ze de naam van: sauan sibarmung: dubbele balg om in te blazen.

58 Het woord sarapian was de Heer Tammu niet bekend. "zwarte rijst is het voedsel er van" en 59 "zwarte harige rijst": deze woorden hebben betrekking op de gloeiende houtskool, op welke het ijzer gesmeed wordt.

59 "het zwarte" ziet hier op het ijzer, dat in de gloeiende kolen gelegd wordt. maleulung is een nevenvorm van malaulung: iets, dat zwartachtig is. 
53 Voor de ouden worden hutten opgezet, voor de heel ouden worden holen gemaakt.

54 Men stelt een blaasbalg op, afwisselend schudt men er aan, men doet het telkens van plaats verwisselen.

55 Ik sta er verbaasd van, $i k$ ben verbijsterd, wanneer ik het overdenk, er naar gissend zonder het te weten.

56 Men maakt er een pijp voor, dan komt er wind, men laat het windvlaagje er langs een vlondertje heen gaan.

57 Dan klinkt het luid in het uitspansel.

58 Als een trom van Sarapian, zwarte rijst is hun voedsel.

59 En zwarte harige rijst, zij stoppen het zwarte er onder.

60 Men trekt het er uit, het ziet er rood uit als de kembang sepatoe, zij houden een droog aaltje vast.

$61 \mathrm{Hij}$ bijt zijn verwanten, hij slaat hen hard met de vuist.

$62 \mathrm{Zij}$ stuiven weg als vuurvliegjes, zij gaan voort als helder schijnende fakkels, hij versiert het ginds.

63 Ik sta er verbaasd van, $i k$ ben verbijsterd, wanneer ik het overdenk, er naar gissend zonder het te weten.

64 Hun witte hond is bij hen.

$65 \mathrm{Hij}$ strijkt het over de slijpsteen.

66 Hij snijdt het af en het krijgt de vorm van een haneveer, hij verzamelt en bundelt ze.

60 danga-danga is waarschijnlijk kembang sepatoe (Hibiscus rosa sinensis). "een droog aaltje" heeft de betekenis van een tang, waarmee het hete ijzer wordt vastgehouden.

61 Regel a wil zeggen, dat de nijptang, waarmee het hete ijzer wordt vastgehouden, in het hete stuk ijzer grijpt.

62 "hij versiert het" heeft de betekenis van: hij slijpt het.

64 asu busa'na "hun witte hond" zal wel de betekenis hebben van: hun slijpsteen, die wit van kleur is.

66 De zin van regel a is: hij geeft er een spitse punt aan. 
67 Napalangngan banuanna, to dao papa bolana.

68 Garang ke birroi allo, ke dolokki sulo padang,

69 la lao rekkemi bamba, la sumembang dua ongan,

70 tamimpa' tallu lalundun, umpala'pa' gora tongkon.

71 Kajo malang dio mai, giring-giring napadolo.

72 Lale' ummantai lalan, natarrusan tama pasa'.

73 Napalan kasirampunan, nadandanan rekke annan.

74 Nabato' rekke karua, natalimbung tau kamban.

75 Naapun 1 indo mairi' nalempe-1empei bajan.

76 Napesonno sudi lalong, rokko natandai pisik.

77 Nade'penni kiding-kiding, allo dellek diong liu.

78 Nalipu-lipu naajun, napalangngan palempengna.

79 Nalembangan dua lette', nabaa rampo i tondok.

80 Napakendekki pangleon, dadi tonapa londongna.

81 Kombong indo' simangkoro, pesese ma'oran pare,

82 urria tallu lolona, naposapan bala tedong,

83 napobangke' pangkung bai, sapanna ma'lolo tau.

70 De zin var regel $\mathrm{b}$ is: een kiekendief laten opvliegen om uit de vlucht daarvan een voorteken op te maken, vgl. H III, str. 66v., waar het woord umpalumpa': "voorop latende gaan" wordt gebezigd.'

76 pisik, in H III: pising-pising, 1tl. plant met roodachtige, rondvormige bladeren, die op muntstukken gelijken.

77 kiding-kiding, 1t1. het glinsterende; door deze manipulatie geeft men te kennen, dat men dat bepaalde zwaard of dat bepaalde mes 
67 Men brengt ze boven in hun huis, boven op het dak van hun woning.

68 Juist, wanneer de zon opkomt, wanneer de toorts van de aarde plotseling verschijnt,

69 zal men Noordwaarts naar de streek gaan, zal men twee schaduwtakken afhouwen,

70 in éên houw drie schaduwtakken afhakken, vooraf een kiekendief latende opvliegen.

71 De grauwe reiger neigt vandaar, hij laat het rinkelbelletje vooraf klinken.

$72 \mathrm{Zij}$ lachen luid bij het gadeslaan van de weg, zij gaan direct de marktplaats op.

$73 \mathrm{Zij}$ brengen ze in de plaats van bijeen zijn, zij stellen ze Noordwaarts in rijen van zes op.

$74 \mathrm{Zij}$ ordenen ze Noordwaarts in rijen van acht, de menigte krioelt er omheen.

$75 \mathrm{Zij}$ worden omringd door aller aangezicht, de parkieten gluren er met een scheef kopje naar.

76 Men onderzoekt en taxeert de dapperen, men zet zich neer en gaat het geld na.

77 Men legt de zilverstukken er op ze aandrukkend met de vingertoppen, de zon gaat er dan op schijnen.

78 ze verzamelen ze en bundelen ze, ze tillen ze op hun schouder.

$79 \mathrm{Zij}$ vervoeren ze te voet gaande, zij brengen ze in het dorp.

$80 \mathrm{zij}$ tillen ze omhoog in de nederzetting, ze zijn hun geweldige klewangs.

81 Gevormd is het zwaard, dat de vorm heeft van een hakmes, het schopje met de steel van een rijststengel,

82 behoedend de drie geboortes, tot bescherming dienend van het fokken van buffels,

83 tot schoeiing dienend van het varkenshok, de bescherming bij het geboren worden van kinderen.

tegen die prijs wil kopen.

79 nalembangan dua lette', 1t1. zij vervoeren ze met hun beide voeten als met een vaartuig; 'lette' is een nevenvorm van lentek = been, voet.

82 naposapan bala tedong, 1t1. die door de buffelstal als afwering wordt gebezigd. 
H. van der Veen - 978-90-04-28716-7 Downloaded from Brill.come4/26/2023 02:54:12PM via free access 
URRODO BANGKULA a) TO, NAKUA (H II)

InZeiding

Deze tekst, aangeduid als "Men schudt de bel en zegt", vormt eigenlijk het tweede gedeelte van de Singgi' Tondok (H I). De to minaa, die bij die Singgi' geen bel hebben geschud, gaan dat bij dit tweede gedeelte wel doen, terwijl zij op forse wijze de lofprijzing reciteren op de machtige lieden in de gemeenschap, de helden van weleer, die er op uit trokken om een kop te snellen.

De geboorte van zo'n held had op buitengewone wijze plaats, de lusten van zijn moeder gingen uit naar testikels van het riviermonster en het vlees van het dikke gedeelte van de krokodil. Hij groeide voorspoedig op en werd een krachtig, notabel, welvarend man in de gemeenschap. De gesnelde kop droeg hij aan een lijntje mee. En dan ging hij de overwinning vieren met een offerfeest.

a) bangkula' is een koperen bel, die gezwaaid wordt bij het reciteren van de lofprijzing en bij de manganda'-dans op het bua' kasallefeest. 
Tekst

1 To mengkita pengkamma'ko, to sae siparapa'ko!

2 Ammu perangiina' mati', ammu tanding talingana'.

$3 \mathrm{Ba}^{\prime}$ tu la denpi kuissan, ba'tu kupeloloi.

$4 \mathrm{Na}$ tangiapa sirenden, na tang tenpa sibalaan,

5 kuanna' do'dona' mai, salana' pakare'nana'.

6 Angku tindok pole'oi, angku pasulleoi, tindokki batu rara'i.

7 Indo'mi 1ao' ri Teang, rumajuk 10' ri Te'tekan.

8 Tia' langkanmoko mai, sajang kaluppini'moko.

9 Rorak manuk-manukmoko, unnisungiko sa'deku.

10 Tongkonko penggirikangku, mutadoina' pantoto.

11 Angku pantoto menani, angku ma'tang sala-sala.

12 Ikomo ampunna nani, kurundu' kupeolai.

13 Kupetimbu' lambananna, tang kupomakule lentek.

14 Patiko-tiko lu mati', patiko-tiko marendeng.

15 Suma 'bu' unnala pare, rongko' ma'mataran-taran.

4 sirenden, 1tl. elkaar voortleiden。

7 mumajuk, een -um-vorm van rajuk, is verwant met pajuk: hoog, verheven.

10 penggirikan, 1t1. plaats, van waar men zich omwendt. 
Vertaling

$1 \mathrm{Gij}$ toeschouwers zwijgt, gij, die als gasten gekomen zijt, houdt u stil.

2 Opdat gij naar mij luistert, gij uw oren spitst.

3 of er iets is, dat ik weet, of er iets is waarvan ik goed op de hoogte ben.

4 En wanneer het niet goed op elkaar volgt, wanneer het nog niet goed samenhangt,

5 zegt het mij, laakt mij, ben ik fout, vermaant mij.

6 Opdat ik wederom met het reciet aanvange, dat ik het vervange, dat ik er mee aanvange als met het opnemen van de kostbare stenen van het gouden halssieraad.

7 Uw Moeder in het Zuiden in Teang, hoog verheven in het Zuiden in Te'tekan.

8 Vlieg hierheen als een kiekendief, zweef als een zwaluw.

9 Trek naar rechts en naar links heen als een vogel, zet u neder aan mijn zijde.

$10 \mathrm{Ga}$ zitten aan mijn zijde, reik mij een snoeimes.

11 Opdat ik snoeie bij het reciteren van de lofzang, ik geen fouten make.

$12 \mathrm{U}$, die meesters zijt van de zang, volg ik en imiteer ik.

13 Ik wil het in mij opnemen als het voorbeeld er van, ik zal er geen gewrichtsrheuma in de benen van krijgen.

14 Wanneer ik maar geregeld "je" tegen $u$ zeg, wanneer ik maar gerust "je" tegen u zeg.

15 Het vermeldende bij het inzamelen van padi, had ik geluk, hoewel ik niet deskundig ben.

13 kupetimbu', 1tl. ik stop het in de mond; Zambananna, 1tl. de plaats van het oversteken er van。

15 "hoewel ik niet deskundig ben", nl. in het reciteren van de singgi'. 
16 To mengkita pengkamma'ko, to sae siparapa'ko.

17 La kulambi'mo dadinna, kudete'mo garaganna.

18 To tang dikandean essun, tang dileran bua kaju.

19 Tu la ditampamo lalong, dikombong kakojan balo.

20 Apa nakande indo'na, apa namambuelo' $i$ ?

21 Rokko dibutoi bendo', dipelassakki buaja.

22 Ia nakande indo'na, tonna ditampa te lalong.

$23 \mathrm{Na}$ la dadi pole' lalong, nakombong pole' kakojan.

24 Langngan ditambuli gandang, dirubak pa'paredean.

25 Anna dadi pole' lalong, nakombong pole' kakojan.

26 Nakulu-kulu dodo', naapun sapuko baine.

27 Garang ke birroi allo, ke dolokki sulo padang,

28 rokko ditambuli padang, dibuak pekali bassi.

29 Dipantananni lolona, diosokki tauninna, sola to rambo-rambona.

30 Mekaau to keengkok, unnoang to kebali'bi'.

31 Nasarombon tauninna, nabissik rambo-rambona.

18 to tang dikandean essun: hem voor wien niets zuurs gegeten werd; nl. toen zijn moeder de zwangerschapslusten had.

20 nomambuelo' $i=$ nakaelo' $i$ : zij begeert het.

$24 \mathrm{Vgl}$. The Chant, p. 20 en 29, IA, str. 12 en 118. gandang heeft hier de betekenis van "vlies", vgl. gandang-gandang tedong: de vliezen, die het jong van een buffel omgeven in de baar- 
$16 \mathrm{Gij}$ toeschouwer zwijgt, gij, die als gasten gekomen zijt, houdt u stil.

17 Laat ik nu komen tot zijn geboorte, laat ik reiken tot zijn vorming.

18 Hem voor wien niets zuurs gegeten werd, geen vruchten gesmaakt werden.

19 Die op de wijze van een dapper man geschapen zou worden, als een monster gevormd zou worden.

20 Wat at zijn moeder, wat begeerde $z i j$ ?

21 Benedenwaarts werd het riviermonster gecastreerd, het vlees van het dikke gedeelte van de krokodil afgehaald.

22 Dat at zijn moeder, toen de dappere gevormd werd.

23 Dan zou er een dappere geboren worden, een monster gevormd worden.

24 Daarboven werden de vliezen doorboord, de baarmoeder doorbroken.

25 Zodat de dappere geboren werd, het monster zich vormde,

26 De vrouwen juichten over hem, het jubelen van de vrouwen omringde hem.

27 Juist toen de zon opkwam, toen de toorts van de aarde plotseling verscheen,

28 toen werd een gat gestoken in de grond, de grond omgewerkt met een ijzeren graafstok.

$29 \mathrm{Zijn}$ navelstreng werd er in geplant, zijn nageboorte er in begraven, en de flarden van zijn nageboorte.

30 De lieden van de onderwereld lieten een kreet van afkeer horen, de lieden van de benedenwereld tierden.

$31 \mathrm{Zij}$ werden bestoven door zijn nageboorte, zij werden bespat door de flarden van zijn nageboorte.

moeder. De Heer Tammu slaat een andere vertaling voor, n1.: Naar boven gaande werd een aanvang gemaakt met het slaan van de trom, werd begonnen met het roeren van de trom; pa'paredean heeft dan volgens hem de betekenis van: hetgeen geslagen wordt.

30 to kebali'bi', 1t1. de lieden, die vinnen hebben; bali'bi': vin aan de buik en de rug van een paling. 
32 Mendadi sarre lolona, kombong tabang tauninna.

33 Garang ke birroi allo, ke dolokki sulo padang,

34 la lao rokkomo alang, diong landa' beloanna, ditokeran danga-danga.

35 Nakasalle pole' lalong, nalobo' pole' kakojan.

36 Tang nalolloanda tau, tang natendeng tau mata?

37 Anak panglollona Kesu', pantaranakna Bangkudu?

38 Anna kasalle madomi', nalobo' tingkara-kara, namaluangan ba' tangna.

$39 \mathrm{Na}$ masindung inaanna, mennuaka' tama tasik,

40 parampang tama minanga, minda ia la susinna?

41 La sipalinpa daona, maulang bulunna toding,

42 makaridi'na karaeng, ao' kumpang tama tasik?

$43 \mathrm{Ao}^{\prime}$ kakumbaja'-baja', ia natete lummpa'.

44 Ungkasolang to ma'lambuk, issong napa'palinda'i.

45 Ta'pian sikano rara', kaluku natuang lamban.

46 Pangi natonti unnorong, anna malutura salu.

47 Anna borrongra uai, otonan dokena lalong.

39 masindung inaanna, 1t1. zijn geest is naar beneden toe wijder wordend.

41 maulang bulunna, 1tl. het als tot een touw ineengedraaide arenpalmvezels zijn van. toding: teken, bijzondere plek op het voorhoofd.

42 makaridi'na, $1 t 1$. het stevig ineengedraaide van. 
32 Zijn navelstreng werd sere-gras, uit zijn nageboorte ontstond de Drakenbloedplant.

33 Juist toen de zon opging, toen de toorts van de aarde plotseling verscheen,

34 toen zou hij naar beneden naar de rijstschuur gaan, zijn versierde rijstschuur daar beneden, versierd met kembang sepatoe. a)

35 Toen dan werd de dappere groot, de geweldige gedijde goed.

36 Werd hij niet door de mensen geprezen, werd hij niet door lieden van vlees en bloed geloofd?

37 De in geneuriede liedjes geprezen zoon van Kesu', de goed verzorgde van Bangkudu?

38 Zodat ..., b)

hij vlug gedijde, hij grootmoedig werd.

39 En hij iemand is van wijde en diepe geest, wiens wortels in de zee dringen,

40 zich breed uitstrekkend tot aan de rivieruitmonding, wie is zijns gelijke?

$41 \mathrm{Zal}$ er nog een zijn, die hem in verhevenheid evenaart, een man van hoge stand bij uitnemendheid,

42 een aanzienlijk man van formaat, een forse bamboe, die overbuigt tot in de zee?

43 Een forse bamboe, die heen en weer wiegelt, daar gaat hij over heen, vooruit schietend.

44 De rijststampenden verdervend, het rijstblok bezigt hij om daarop het er af te slaan.

45 Het kaf is vermengd met kralen van het halssieraad, hij neemt de kokosnoot mee onder het oversteken.

46 Een pangi draagt hij mee bij het zwemmen, zodat de rivier troebel is.

47 Zodat het water erg rood is, vanwege het indompelen van de lans van de dappere.

a) Door Van der Veen onvertaald gelaten, door Sw. m.b.v. woordenboek vertaald.

b) Door Van der Veen onvertaald gelaten.

44 "het er af slaan", nl. het hoofd van de persoon, die aan het rijststampen is en door hem gedood is.

$45 \mathrm{~b}, 46$ en 47 hebben de betekenis, dat hij een gesnelde kop meeneemt, vgl. The Chant, p. 76v., R 2, str. 13v.; kaluku, 1t1. kokosnoot.

46 pangi zie E II, 7. 
48 Pangojaran penainna, tikadedek bainena.

49 Melale' sangbanuanna, napa'parampoi sae.

50 Tang napopentaruk induk, tang umpopellolo tallang.

51 Nasembang napobala'ba', natimpa' pa'pararukan.

52 Kukalle-kallei aku, pusa'na' umpenaanni.

53 Nadandanan dao para, to dao lindo banua.

54 Sitaradisi-disian, tae' lale'na kurangi.

55 Napobaine tabuan, napoka'din simadoan.

56 To mengkita pengkamma'ko, to sae siparapa'ko.

57 Allen pa'datu-datuko, kulolloampa sandoku.

58 Lala ma'denna i upa', la kupamuntui nani.

59 La kukaban karombian, annana' matua induk,

60 anna banu' karurungan, dipobala-bala tondok.

61 Bangke'na sa'de banua, buda panglambe kubenko.

62 Dikki' ma'mataran-taran, la mubenna' aku pira.

63 Bela manglambena' aku, tapada 1 indo masakke.

64 Anta banu' karurungan, anta pasakke penani, tadarinding karombian.

54 sitaradisi-disian = sikatadisi-disian (H III, str. 267) gewoonlijk gezegd van lieden, die lachen, zodat het witte der tanden zichtbaar wordt; de woorden zijn verwant met isi "tand".

58 pamuntu: braadpan van hard ijzer; umpomuntui, 1 t1. staal voegen bij week ijzer om het hard te maken.

63 lindo masakke, 1tl. koel van gelaat. 
48 Het zwiepen van zijn zwaard, het heldere lachen van zijn vrouw。

49 Zijn buren lachen luid, hem begeleidend bij zijn komst.

50 De suikerpalm niet latende uitspruiten, de bamboeloten niet latende uitkomen.

$51 \mathrm{Hij}$ hakt ze af om ze te bezigen als een blad van de suikerpalm, welks nerven ineengedraaid zijn,

hij houwt ze in eén slag af om als offerstel te dienen voor het offer na het behalen van de overwinning.

$52 \mathrm{Ik}$ ben er verbaasd van, ik ben verbijsterd, wanneer ik het overdenk.

$53 \mathrm{Zij}$ stellen ze in rijen op boven aan de schuin overhellende voorgevel, boven aan de voorzijde van het huis.

$54 \mathrm{Zij}$ zijn met elkaar gul aan het lachen, geen schel gelach van hen hoorde ik.

$55 \mathrm{Zij}$ huwen een wesp, zij trouwen met een wesp met dun middellijf.

$56 \mathrm{Gij}$ toeschouwers zwijgt, gij, die als gasten gekomen zijt, houdt u stil.

57 zet $u$ goed neder, zoals een vorst zich nederzet, dat ik $u$, mijn vertrouwde vriend, lofzinge.

58 Opdat het mocht zijn, dat ik de lofredekracht verlene.

59 Opdat ik onkwetsbaar $z i j$ bij het reciet van de lofzang, opdat ik oud worde als de arenpalm,

60 even lang van levensduur als het harde kernhout van de arenpalm, beschouwd als een omheining van het dorp.

61 Een omrastering om het erf, vele zegenbeden geef ik $u$.

62 Vele zijn als het ware snedig, wil mij er enige geven.

63 Het is daarom, dat ik de wens uitspreek, mogen wij wederzijds voorspoed hebben.

64 Mogen wij een levensduur hebben als het harde kernhout van de arenpalm, wij gezegend zijn bij het reciteren van de lofrede, geluk ons deel zijn bij het uitspreken van de lofprijzing. 
H. van der Veen - 978-90-04-28716-7 Downloaded from Brill.come4/26/2023 02:54:12PM via free access 


\section{Inleiding}

In deze "lofprijzing op de held", gereciteerd door de to minaa $\mathrm{Ne}^{\prime}$ Todinglele uit To'jasa (Tikala) wordt op daverende wijze de held gehuldigd, met forse, kernachtige, felle woorden, str. 19v.

Zijn geboorte had op buitengewone wijze plaats, als in de bovenwereld geschied. Hij groeit voorspoedig op en wordt als een hoge waringin, die zich beschermend uitstrekt over de adatgemeenschap.

Zijn huis wordt opgetrokken van kostbaarheden als bouwmaterialen, str. $87 \mathrm{vv}$.

Het gaat hem bij alles voorspoedig, hij wint geregeld bij het wedden bij de hanengevechten, str. 170-174.

Hij wordt gekarakteriseerd als een grootmoedig man, iemand, ruim van hart, str. 180, als de machthebber over de hele gemeenschap, str. 184. Hij volgt de vaste cyclus van de offerverrichtingen, opeenvolgend als de treden van een trap, str. 203. Hij is de beschermer van het dorp tegen de vijand, str. 215; hij is het watermonster de baas en durft zelfs een krokodil wel aan, str. 220 .

Uitvoerig wordt gehandeld over de overvloedige oogst van deze machtige, rijke man in de adatgemeenschap, str. 283-310. Ook heeft hij een heel groot aantal hoenders; steeds weer komen er kuikens uit de eieren, str. 312-316. Hij heeft een haan, die kakelt en kraait, en dan verschijnen er buffels, str. 317 (vgl. het hoen van Lapandek, zie H I, str. 12). Ook bezit hij een groot aantal varkens, str. 319v. 
Tekst

1 Tipatumbanna te a1lo, tiapanan te masiang?

2 Te dao to paonganan, angku kendek inde mai, tangdo' lepongna deata.

3 Kumangnga-mangngai aku, pussakna' umpenajanni.

4 Enda' musalla musallaona', muparamban buluona'.

5 Rapa'ko kuondoi, kupembulisu-lisuko.

6 Padaki' kita diindan, pada dilando lalanni.

7 Napobelo-belo bua', napomarongka saoan.

8 Indete lempo bulaan, tangdo' lepongna deata.

9 Iko angga to mengkita, to tibussan tama bua', to limbong ma'balinono,

10 sere-sereko patunna, pallaiko tingajona.

11 Nasarombonko manii nani, ammu kuamo kumua, ammu patenni ma'kada:

12 "Tibeno-beno te rante, tidondan te kala'paran."

13 Kusanga batara kendek, puang usso'boi rante, anna sandokura ia.

14 Kendekmi ma'lui' bassi, ma'kararran bale tau.

6 Deze strofe heeft de betekenis, dat zowel het platform als de to minaa geleend en gezocht zijn om het bua'-feest een sacraal karakter te verlenen. 
Vertaling

1 Hoe is het gesteld met deze dag, hoe is het met deze morgen?

20 heer in den hoge, die alles omhult, dat ik langs deze trap opklim, het cirkelvormige platform der goden.

3 Ik ben er verbaasd over, ik ben verbijsterd, wanneer ik het overdenk.

4 Trap, gij verbiedt het, gij verbiedt het mij weer, gij doet mij maar weer de haartjes te berge rijzen.

5 Houd u rustig, dan beklim ik $u$, dan wend $i k$ mij op $u$ heen en weer.

6 Gelijkelijk zijn wij geleend, gelijkelijk heeft men ons van verre gezocht.

7 Om tot sieraad te strekken van het bua'-feest, ter verlevendiging van de omgang.

8 Hier is de gouden verhoging, het cirkelvormige platform der goden.

9 Alle gij toeschouwers, die op het bua'-feest verschenen zijt, die in menigte samengestroomd de optocht vormt,

10 gaat, naar het behoort, op $z i j$, gaat weg van de voorzijde.

11 De lofprijzing zou u kunnen bestuiven, zodat gij zoudt zeggen, als volgt zoudt spreken:

12 "Deze feestplaats is aan het schudden, dit $I_{a}^{\prime} p a^{\prime}$-feestterrein beweegt heen en weer."

13 Ik denk: de hemel rijst op, de god betreedt de feestplaats, en het is mijn vertrouwde vriend.

14 Hij klimt op met een huid van ijzer, hij heeft een pantser aan, belegd met ronde stukjes mensenvlees.

8 Deze strofe bevat twee dichterlijke omschrijvingen van de gorang, het sacrale platform waarop de twee priesters de lofprijzing reciteren.

$14 \imath_{u} i^{\prime}=Z_{i u}$ ', als werkwoord: "villen". 
15 Tirori tirori lako, tungka pata'pai mata.

16 Nasura dokemo' diong, narompo mata bassimo'.

17 Mangngana' sisombo', leagana' sitau mata.

18 La kukuari pale'na, la tendi pa'kadanangku.

19 La dikarombian bendo', 1a unnassa buaja.

20 La kukarombian pa'du, la unnassa mapai', untendeng buku langsa'.

21 Karombian siura'na, ba'baran sangkalamma'na.

22 Nasolan torro matogon, unnisung nakatongan-tongan.

23 Karombian busarungngu', ba'baran bupare kombong.

24 Iamo torro paria, unnesung pasaladan.

25 La kukua pole'omi, la tenni pa'kadanangku.

26 La kulambi'mo dadimmu, kudete'mo garagammu.

27 To tang dikandean essun, tang dileran bua kaju.

28 Tang ambaang tang dadeko, tang pao tang ilu-ilu.

16 Naast degene tot wie de lofprijzing gericht wordt staat een lans opgesteld.

19 unnassa is een um-vorm van tassa, waarbij de $t$ in de nasalering is geabsorbeerd; tassa: afsnauwen, felle verwijtingen uiten gepaard gaande met het stampen van de voeten. De betekenis van deze en de volgende strofe is deze, dat de dappere held op een zeer krachtdadige wijze wordt geprezen vanwege zijn niets ontziende dapperheid. Het kwam soms voor, dat zij die op een dergelijke wijze in de singgi' werden toegesproken, in paniek geraakten of flauw vielen. Men meende dan wel, dat de lofprijzing te ver ging, niet in overeenstemming was met hun krijgsdaden, maar in werkelijkheid waren $z i j$ aangegrepen door de felle woorden. 
$15 \mathrm{Kijkt}$, kijkt er naar, vestigt uw oog er echt op!

$16 \mathrm{Hij}$ steekt daar beneden met een lans, als met een voetangel, hij omheint mij als met het lemmet van een wapen.

17 Ik ben zeer verbaasd bij het aanschouwen van elkaars gelaat, $i k$ ben verbijsterd bij het oog in oog staan.

$18 \mathrm{Ik}$ zeg het dan toch maar, zo dan is hetgeen ik te zeggen heb:

$19 \mathrm{Hij}$ zal op monstrueuse wijze vermeld worden in de lofprijzing, hem krachttermen toeroepend.

20 Ik zal hem de lofprijzing toewerpen als ware het gal, op bittere wijze hem toesprekend, ik zal hem op harde wijze loven, hard als de pit van een langsatvrucht.

21 Met een lofprijzing, geschikt om hem geluk aan te brengen, met een amechtig makende vloed van woorden, die passend zijn voor een vriend.

22 Die voert hem mee, rustig blijvend, die zet zich wezenlijk neer.

23 Een geurige lofprijzing, de geur hebbend van harige witte kleefrijst.

24 Die is een beschermer, die is gezeten koesterend.

25 Ik zeg het wederom, zo dan is hetgeen ik te zeggen heb:

26 Ik ben gekomen tot uw geboorte, ik bereik reeds uw vorming.

27 Iemand voor wie het zure niet gegeten werd, geen vruchten werden voor hem gesmaakt.

28 Geen grote mangga-vruchten met een sterke terpentijnsmaak, geen mangga-vruchten, geen pao-mangga, geen vruchten, die de tanden stroef maken.

20 De langsat-vrucht is de Lansium domesticum.

21 ba'baran: een amechtig makende woordenvloed.

28 ambaang (Indonesisch: embatjang) is de Mangifera odorata, een grote mangga-soort met sterke terpentijngeur.

pao is de Mangifera indica. 
29 Rokko dibutoi bendo', sae napepanoranni.

30 Ia nakande indo'na, nakantulen-tulenanri.

31 To diparede bumbungan, to dikombong pare puru',

32 dikauan tallu manuk, barra' dirangga-dirangga, bo'bo' didatui manna.

3.3 Anna la denda susinna, la sipalinpa daona, la pada tintiananna?

34 To tang dikitta' dadinna, tang didete' garaganna.

35 To tang dadi ri posi', tang ombo' ri bannean.

36 Mambela dadinna lalong, kombong kamasuliranna.

37 Daari ulunna langi', daa tibassena Lemba.

38 Tiampanna Pariama, madandananna botikan.

39 Marempa-marempa dadinna, maga'gun mentolinona.

40 Ditambai to minaa, diindan rangga inaa.

41 Sae umbille alukna, umpemangsan bisaranna.

42 Mapinde-pinde alukna, mapiangla' bisaranna.

43 Anna dadi sangdadian, ombo' sangtibussanan.

31 diparede bumbungan, 1t1. hij werd als melk vloeibaar gemaakt, d.w.z. hij werd op grootse manier geschapen.

34 dikitta' is de intensieve vorm van dikita: het is geraakt, getroffen, 1t1. het is gezien.

38 botikan: hetgeen zich voordoet, verschijnsel; de verschijnselen, die in rijen staan, zijn de sterren; botikan, vg1. boti': worden, geschieden. 
29 De testikels van het riviergedrocht werden genomen, de uiers van de pythonslang werden benut.

30 Die at zijn moeder, $z i j$ had het er steeds over.

$31 \mathrm{Hij}$ is degene, die op vlotte wijze is ter wereld gebracht, hij is degene, die gevormd is, als ware hij kleefrijst,

32 voor wie een kippeëi gestoten werd, als ware hij ontbolsterde rijst in verschillende kleuren bereid, rijst, zoals die slechts voor een edele wordt toebereid.

33 zou er één zijn aan hem gelijk, zou er één zo verheven zijn, zou er één zijn, die hem evenaart?

$34 \mathrm{Hij}$ is iemand wiens geboorte in het geheel niet doorzien is, tot wiens vorming men niet is doorgedrongen.

35 Die niet aan de navel geboren is, die niet uit de schoot te voorschijn kwam.

36 In de verte was de geboorte van de held, zijn vorming was een uniek gebeuren.

37 Ginds aan het oppereinde van het uitspanse1, in het Noorden waar het sterrebeeld van de Beer is opgehangen.

38 Aan de helling van de Pleiaden, bij de verschijnselen, die in rijen staan.

39 Zijn geboorte verliep traag, en langzaam zijn menswording.

40 De to minaa werd geroepen, men maakte gebruik van de kennis van hem, die rijk is aan inzicht,

$41 \mathrm{Hij}$ kwam de verschillende offervoorschriften voor hem schiften, en de adatinzettingen voor hem er uitlezen.

42 Verschillend waren de offervoorschriften voor hem, opwindend de adatinzettingen voor hem.

43 Er waren die met hem gelijktijdig geboren werden, er waren die te zamen met hem ter wereld kwamen.

40 diindan, 1t1. hij werd geleend; de betekenis van deze uitdrukking hier is, dat men gebruik makte van zijn kennis van de adatvoorschriften, vg1。 The Chant, p. 48, IC, str. 19.

41 umbille, 1t1. uiteenhalen, van elkaar scheiden. 
44 Didadian tumalinting, kombongmi ma'rengo-rengo.

45 Ditampan pekali bassi, dipantananni lolona.

46 Dipada' rambo-rambona, tuo temun diong mai.

47 Dadi sarita lolona, kombong maa' tauninna.

48 Dilellenan sumapuko, ditendeng ma'kulu-kulu, lummi' seno peurangan.

49 Anna kasalle dadinna, anna 1obo' garaganna.

50 Kasalle naria aluk, lobo' nasambe' bisara, naria pengkalossoran.

51 Kasalle naria suru', lobo' nasambe' sara'ka'.

52 Tondok boro toda langi', banua mapia toda.

53 Kari' la sa'timo daa, kari' tang la sule lenna.

54 Ditalo allira rekke, dipa'bolon-bolonanni.

55 Rekke ditetei aluk, dipelalanna bisara.

56 Rekke ditetei suru', dipelalanni sara'ka, diembe' pengkalossoran.

57 Rekke ditetei pusuk, diembe' lumbaa langi'.

58 Sumonglo' bangrika lalong, ke'de' samo-samorika?

44 ma'rengo-rengo: de klapper schudden; dit doet men om de rijstdiefjes van de sawah te verjagen.

48 Regel c werd door $\mathrm{Dr}$. Van der Veen niet vertaald. (Red.)

50 nascombe', 1t1. hij werd in een draagband gedragen. 
$44 \mathrm{Hij}$ werd ter wereld gebracht onder een helder klinkend geluid, hij werd gebaard terwijl men de klapper liet kleppen.

45 Een $i j z e r e n$ graafstok werd voor hem gesmeed, en daarmee werd zijn navelstreng begraven.

$46 \mathrm{Zijn}$ nageboorte werd in aarde begraven die stevig werd vastgedrukt, zij groeide daaruit op als komkommer.

47 Zijn navelstreng was een sarita, zijn nageboorte had de vorm van een maa'-weefsel.

48 De juichkreten werden voor hem aangeheven, men deed het hoera-geroep voor hem daveren.

$$
\cdots
$$

49 Opdat hij voorspoedig zou opgroeien, zijn gestalte zich gunstig zou ontwikkelen.

$50 \mathrm{Hij}$ werd groot, beschermd door de offerverrichtingen, hij groeide voorspoedig op, behoed door de adatinzettingen, gekoesterd door het brengen van uitdelgingsoffers.

51 Hij werd groot behoed door de zoenoffers, hij groeide voorspoedig op door de reinigingsoffers gedragen.

52 De hemel was toch een lieflijk oord, een fraaie woning toch.

53 Het scheelde weinig, of hij was er vast gebleven, bijna zou hij er nimmer van zijn teruggekeerd.

54 Voor hem werd een heel hoge prijs opwaarts in het Noorden betaald, voor hem werd veel geld uitgegeven.

55 Noordwaarts werd een brug van offerverrichtingen geslagen, werd een weg aangelegd van adatinzettingen.

56 Noordwaarts werd een brug geslagen van zoenoffers, werd een weg aangelegd van reinigingsoffers, werd het uitdelgingsoffer tot een klimstrik gemaakt.

57 Noordwaarts werd een brug geslagen van opengevouwen jonge bladeren van de arenpalm, werd de bambu aur-stengel tot een klimstrik gemaakt.

58 Zou de held dan zo maar afdalen, zou hij dan zo zonder iets vertrekken?

57 Zrmbaa Zangi': de stengel van de bambu aur met de bladeren er aan doelt hier op het bua' kasalle-feest. Op dat feest wordt zulk een stengel Noordwaarts gericht bij de gorang opgesteld en daaraan een korfje met een witte kip er in bevestigd, zie J. Kruyt (1921), 66. 
59 Sumonglo' dibombonganni,

ke'de' dirapa-rapai.

60 Anna songlo' daa mai, anna lao sambalin mai, bu'tu lamban diong mai.

61 Lalan tang lalan naola, tang lambanan napellesei.

62 Tindak sarira naola, mian kila' napolalan.

63 Unnola tumetena bulan, ke tumanan baraninna.

64 Anna songlo' daa mai, umpemaelo manukna, umpesampa' garentena.

65 Giring-giring napadolo, lale' ummatai lalan.

66 Tinti kanan kairinna, umpalumpa' gora tongkon.

67 Kajo malang dio mai, langkan lumisu lu langngan.

68 Unnola buntu tang damma', tanete tang beluakan, lombok tang roto-rotoan.

69 Anna lamban diong salu, salu unnondo batanna, salu tumbang karanganna.

70 Anna kendek diong mai, anna mentete randanan.

71 Unnola tampo malolo, kadajang tang silambanan, kalo' tang siperapian.

72 Mane palangkana tondok, mane tambing salianna.

66 tinti is het kwinkelerend geluid van de kaloko-vogel, een soort koekoek. Dit geluid is een gunstig voorteken. gora tongkon, 1 t1. de zittende roeper (Pangala'), elders: langkan tua $=$ pokkatua: een soort kiekendief, wiens geschreeuw de regen roept, vandaar ook zijn naam: langkan uran: de regenkiekendief. 
$59 \mathrm{Hij}$ daalde af, terwijl de gong voor hem geslagen werd, hij vertrok met veel geklank.

60 Opdat hij van het Noorden zou afdalen, hij van ginds zou komen, hij van die zijde overkomende zou verschijnen.

$61 \mathrm{Hij}$ ging langs een weg, die geen weg was, hij betrad hetgeen waar men niet overheen kon gaan.

62 Hij ging langs de regenboog, hij bezigde de bliksemflitsen als weg.

$63 \mathrm{Hij}$ ging langs het door de maan betreden pad, wanneer die de gestalte heeft van de eerste nacht na volle maan.

64 Opdat hij van het Noorden zou afdalen, op een goed voorteken voor hem wachtend, zijn trillend geluid afwachtende, hetgeen een goed voorteken is.

65 Een belletje liet hij vooruit gaan, een luid gelach gaf de weg aan.

66 Een kwinkelerend geluid rechts en links van hem, de kiekendief voorop latende gaan.

67 De grauwe reiger neigt zich vandaar, de kiekendief vliegt in een kring opwaarts.

$68 \mathrm{Hij}$ gaat langs een berg die in het geheel niet gebarsten is, een gebergte zonder scheurtjes, een dal zonder gaten.

69 Toen stak hij de rivier over, een rivier welks stenen aan het opspringen waren, een rivier welks kiezels aan het huppelen waren.

$70 \mathrm{Hij}$ steeg op vandaar, en schreed langs de oever.

$71 \mathrm{Hij}$ liep langs de rechte sawah-dijk, het dijkje, dat niet in een ander overging, een greppe1, die niets aan een andere vroeg.

72 Pas was het de buitenzijde van het dorp, pas was het het buiten liggende.

72 palangka: platform, verhoging van de vloer aan de zijkant van het huis; in dit verband wordt het gebezigd ten aanzien van het dorp. tambing: aanbouw aan de buitenzijde van een huis bijgebouwd. 
73 Sae tumonggona uru, umbarana' dipangleon.

74 Anna la denda susinna, balimbingna diorongi, tangkena dikulea'i?

75 Orong-orongan to topo, pessimbongan to tangdia', ukkunan to toang kale.

76 Anna la denda susinna, la sipal inpa daona, la pada tintiananna?

77 Di ruma-ruma tondokna, dikalampang sulunanna.

78 Diruma-ruma bubunna, dikalampang turunanna.

79 I) iruma-ruma pemala', dikalampang kuli' piong.

80 To' liku-liku bambana, tasik pollo' banuanna.

81 Orong-oronganna tedong, pessimbonganna kanae, ukkunan sakean boro.

82 Natalimbung kanan tedong, naapun pa'pairusan.

83 Diruma-ruma sendana, dikalampang kuli' pindan.

84 Apa sanganna te tondok, genteranna te pangleon?

85 Manik mariri litakna, tinggi ongan banuanna.

73 Een heel grote uru-boom en een waringin zijn de symbolische uitdrukkingen voor een voornaam, machtig persoon.

74 diorongi: $1 t 1$. waarheen gezwommen wordt. dikulea'i, $1 \mathrm{tl}$. waarheen gezwommen wordt door beurtelings de armen uit te slaan.

75 ukkunan, 1 tl. de plaats waar men in duikt. toang, elders tojang: mager, schraal.

77 diruma-muma: er wordt geplaatst een ruma-muma, d.i. een hutje aan de Noordzijde van het huis, van waaruit het bua' kasalle-feest gevierd wordt; daaraan wordt de liaan (bambalu) bevestigd, die dat hutje verbindt met de tangdo' kalua'. Het offer voor de tangdo' kalua' wordt in deze ruma-muma neergelegd. Bij de beschrijving van 
$73 \mathrm{Hij}$ werd als een heel grote uru-boom, zijnde een waringin in de nederzetting.

74 zou er een gelijke van hem zijn, tot wiens steunwortels men zijn toevlucht neemt, tot wiens takken men zich om hulp richt?

75 Het toevluchtsoord voor de gebrek lijdenden, tot wien de hongerigen om hulp komen, de plaats van hulp voor de mensen, die er schraal uitzien.

76 zou er éen zijns gelijke zijn, zou er éen zo verheven zijn, zou er één zijn, die hem evenaart?

77 Bij zijn dorp wordt een offerhutje geplaatst, bij de ingang van zijn dorp wordt een afdakje opgezet.

$78 \mathrm{Bij}$ zijn bron wordt een offerhutje geplaatst, bij zijn wel wordt een afdakje opgezet.

79 Er wordt een hutje opgezet voor offers bestemd, er wordt een afdakje opgezet voor de bamboekokers in welke rijst met vlees gekookt wordt.

$80 \mathrm{Zijn}$ woonplaatst is een plaats van waterkolken, de achterzijde van zijn huis een zee.

81 De plaats, waarin de buffels zwemmen, de plaats, in welke de karbouwen in het water plonzen, de plaats, in welke de vreedzame rijdieren gaan duiken.

82 De buffels verzamelen zich rondom de plaatsen, waar ziltig water uit opborrelt, zij omringen de drinkplaatsen.

$83 \mathrm{Bij}$ de tjendana wordt een offerhutje geplaatst, bij de glanzende wordt een afdakje opgezet.

84 Wat is de naam van dit dorp, de benaming van deze nederzetting?

85 Zijn grond bestaat uit gele kralen, de plaats van schaduw van zijn huis bestaat uit rode kralen.

het bua' kasalle-feest in Pangala', die in J. Kruyt (1921) te vinden is, wordt vermeld dat de ruma-ruma een toestel is als een tafel met vier wielen; het $\mathrm{Wb}$. geeft: "een draagstoel op welke de to tumbang de feestplaats van het bua' kasalle-feest worden rondgedragen." Misschien heeft de term hier en in str. 79 en 83 de betekenis gekregen van: wordt gewijd met een offer.

$79 \mathrm{kuli}^{\prime}$ piong, $1 \mathrm{tl}$. de schil van de bamboe-geledingen in welke rijst met vlees wordt gekookt, heeft de betekenis van: offers in bamboekokertjes gekookt. 
86 Napa'bangunni banua, napa'marongka-rongkai.

87 Umpoparandangan pindan, andelen napoa'riri.

88 Pangden naposulu' tedong, pio kalando petolo'.

89 Kala'ka' tando ianan, bendan kaluku issongna.

90 Alu tibuso bandangan, barang ditambane gallang.

91 Beno pelambe masua', rara' tibekka enda'na.

92 Tando' pangalloan maa', pamallaran tuda-tuda.

93 Ampang pembassean seleng, gaang gumeilo pata'na.

94 Sali limbong tuda-tuda, manangnga ditanan gaang.

95 Bintoen roto rindingna, sambo rinding pai'pinan.

96 Petuo ra'pe busirrin, bulean napomanete.

97 Pio kalando tokeran, kiding-kiding tarampakna.

98 Uang passengoranna, tindak sarira longana, lotong boko' bubunganna.

89 Deze balken zijn in de tongkonan-huizen van de stam van de arecapalm; de bedoeling hiervan is, dat de bezittingen zich zullen vermeerderen. 
$86 \mathrm{Hij}$ richt er een huis op,

hij legt er een plaats aan, waar allerlei geplant wordt.

87 Schotels bezigt hij als fundamenten, welriekend gras bezigt hij als stijlen.

$88 \mathrm{Hij}$ neemt een fijne, geurige grassoort als afsluiting van de karbouwenstal,

lange lendengordels zijn de latjes door de openingen van de stukken bamboe dakbedekking gestoken om ze aaneen te rijgen.

89 De balken onder de vloer zijn de schraag voor de kostbaarheden, zijn rijstblok staat er als een kokosnoot.

90 De rijststamper wordt geschud als een stok met geitehaar, de wan wordt van een rand voorzien van messing.

91 De zeef is een aanhoudende smeekbede om grote dapperheid, zijn trap bestaat uit treden van rara'-klossen.

92 De voorgalerij is de droogplaats van oude doeken, de plaats, waar de oude weefsels worden opengevouwen.

93 De dwarsbalk aan de bovenzijde van het kozijn is de plaats waar de seleng-doeken worden opgehangen,

de onderlengtebalk is een gekronkelde gouden kris.

94 De vloer is een verzameling van oude weefsels,

de brede stijlen aan de wand, waar de houten platen van de wand worden ingeschoven, zijn op gouden krissen opgesteld.

95 De reten van de wanden zijn sterren, de balken aan de zijkanten van het huis drukken op de wanden.

96 De pinnen aan de palen binnen in het huis buigen neer vanwege de oude doeken met mierenfiguurtjes,

blaasroeren van zwart hout heeft het als nokbalk.

97 Lange lendendoeken zijn de latten, aan welke de stokjes aan welke de stukken bamboe dakbedekking geregen worden, worden opgehangen, kleine platte stukjes goud, die van de hoofdband van vrouwen op feesten gedragen ( $\left.s a^{\prime} p i^{\prime}\right)$ afhangen, zijn de korte stukken bamboe aan de dakrand.

98 Oude munten zijn de stukjes uit de inkepıngen van de stukken bamboe dakbedekking geslagen,

een regenboog is de overhellende luifel aan de voor- en achterzijde van het dak,

een weefsel met een figuur van een buffel met zwarte rug is de platgeslagen bamboe van de nok. 
99 Dapo'opa tu kulambi', dapo' tamben bala tedong, lalikan sombo rongko'na.

100 Tang ruro rambu apinna, napantanakki bumbungan, napa' pamakko-makkoi.

101 Anting-anting palanduan, baroe' sisiran siruk.

102 Siruk mangsan palisunna, pesangle ma'lila tedong.

103 Petimba kambu bulaan, pantu'tukan penamile.

104 Passaran limbongan duro, kandian ditedong-tedong, pangromokan tombang tedong.

105 Umpopara-para allo, umpopalangka bintoen.

$106 \mathrm{Ma}$ 'dandanan kampolona, tibantuk baka buana.

107 Pirri' seleng laan leu, maa' mata puo manna.

108 Tanduk donga do lu pirri', napassedanni tonapa.

109 Kaleang situlambenan, susi rompon peda-peda.

110 Oting-oting sae duka, te'tekan mendolo inde.

111 Mindao ia la susinna, la sipalinpa daona, la pada tintiananna?

112 Serre'opi to kulambi', serre' annan palisunna, karua tanda-tandana.

101 Regel b werd door Dr. Van der Veen niet vertaald. (Red.)

103 De kambu wordt om de bek van een kalf gebonden, wanneer men de moederbuffel wil melken. penomize, 1tl. grote, volwassen buffelstier; in d.t.: een lang zwaard.

107 seleng: oud $\mathrm{tj}$ indai-weefsel. puo, elders pujo: kwartel. 
$99 \mathrm{Nu}$ kom ik ook nog aan de haard, de randen van de haard zijn dwars op elkaar gelegde balken zoals van een buffelstal, de stenen van de treeft hebben een kenmerk van geluk.

100 De rook van het vuur daarop stijgt voortdurend op, men kookt er melk op, men laat ze er voortdurend op dik worden.

101 Het rek boven de haard voor het brandhout geeft een tingelend geluid,

102 De lepels van uitgelezen hout hebben houtaders, de scheplepels hebben de vorm van buffeltongen.

103 De waterschepper is een gouden muilkorf, de vijzel is als (de bek) van een volwassen stier.

104 De houten groenteschaal is vol oliehoudend vocht, in de etensschaal zijn buffelfiguren gesneden, de bak, waarin men de borden spoelt, is (diep als) een buffelwed.

105 Het rekje, dat hij voor het eetgerei heeft, is als de zon, sterren vormen de verhoogde vloer or van.

106 op rijen staan de lage korven voor de sieraden, de korven met houten deksels staan naast clkaar.

107 Ze zijn geheel gevuld met seleng-doeken, uitsluitend maa'-doeken met kwartel-ogen.

108 Er boven zijn een menigte hertehorens, waaraan klewangs zijn opgehangen.

109 De klewangs liggen door elkaar heen, als romel van zwaarden.

110 De puntige uiteinden zijn er ook uitgekomen, de vuurslag is hier reeds gereed.

111 Wie dan zou zijns gelijke zijn, even verheven zijn als hij, zou hem evenaren?

$112 \mathrm{Ik}$ ben tot aan de kat gekomen, de kat met zes haarwervels, met acht kentekenen. 
113 Serre' tang mate anakna, tang marantan sumanga'na.

114 Ia umponnoi baka, ia mpakala'bi-la'bi.

115 Ueopa te kulambi', ue sitammu bukunna, ia napobassean turruk.

116 Maempunmo tendengna sondong, lolloranna banua.

117 Nanai tumangke suru', suru'na rampanan kapa', sara'ka' kaso mentamben.

118 Uase kondo silopak, rante tondon pada dua.

119 Anna la denda susinna, la sipalinpa daona?

120 Tungara tana natokkan, lumpang langi' namisai.

121 Ia umba'gi redekki, napa'indo' tamanangi.

122 Napasisulle natimba, napasibuntean-tean.

123 Tiro-tirori lako, tungka para'pai mata.

124 La kukua pole'omi, turiangnamo kulambi'.

125 Turiangna pampang langi', tarangga to paonganan, messerok tiku batara.

126 Natole tumangkei suru', suru'na tengko tiranduk.

$127 \mathrm{Na}$ masiang to makale', nakapana'-panaranna,

128 nalaoan ri bambana, nake'deran sulunanna.

113 sumanga': "levensgeest" heeft in dit verband de betekenis van: levenszaad, nakroost.

115 sitarmu "dicht bijeen hangen" wordt meestal van vruchten gezegd.

117 kaso mentamben, $1 \mathrm{t} l$ 。de daksparren, die schuin gekruist over elkaar liggen, d.t. voor "echtverbintenis". 
113 De kat, wier jongen niet dood gaan, wier nakroost niet afneemt.

$114 \mathrm{Zij}$ vult de korf, zij doet de inhoud steeds meerder worden.

$115 \mathrm{Ik}$ ben dan nu gekomen tot de rotan, rotan, wier knopen bijeen komen, die als lijn gebezigd wordt voor hetgeen dicht bijeen hangt.

116 Ten einde is de lof op het huis, het prijzen van de woning.

117 De plaats, waar het zoenoffer wordt verricht, het offer van de huwelijksplechtigheid, het reinigingsoffer van de echtverbintenis.

118 De grote bijlen liggen in lagen op elkaar, het vlak en de rug zijn even groot.

119 Zou er iemand zijn aan hem gelijk, even verheven zijn als hij?

$120 \mathrm{Hij}$ heeft het alleenrecht over de uitgestrekte aarde, hij heeft de alleenheerschappij over het zich neerbuigende uitspansel.

$121 \mathrm{Hij}$ heeft er voor een weinig deel aan, hij staat er voor in als een kinderloze.

$122 \mathrm{Hij} \mathrm{laat} \mathrm{het} \mathrm{afwisselend} \mathrm{putten,}$ hij laat het bij beurten geschieden.

123 Aanschouwt hem, werpt uw blik werkelijk op hem!

124 Laat ik het wederom zeggen, ik ben gekomen tot aan zijn majestueuze titel.

$125 \mathrm{Zijn}$ titel is: de buffel met breed uitgestrekte horens van de hemel, de buffel met gebogen opwaarts lopende horens van het uitspansel, die de kop omwendt over het gehele firmament.

126 Wederom verricht hij het zoenoffer, het offer voor het landbouwbedrijf.

127 En de volgende dag in de ochtend, wanneer het heet is,

128 dan gaat hij van zijn erf af, dan vertrekt hij uit de afsluiting van zijn hof. 
129 Giling-giling napadolo, lale' umatai lalan.

130 Tinti kanan kairinna, lombo'-lombo' nakabiri'.

131 Tanete nasuru mata, nabandanganni pekali.

132 Naambo'i pising-pising, tuo temun diong mai.

133 Sumarre-marre lobo'na, ma'don kande to lolona.

134 Ia massonggo malea, merrabekan susi bola.

$135 \mathrm{Na}$ masi'ang to makale', nalembai susi rompon.

136 Naben tang kalapute, anna parampo i tondok.

137 Napakenden banuanna, nabelo-beloan sondong.

138 Sumpakna sa'de dapo'na, ia to sesa nakande.

$139 \mathrm{Ra}$ 'dak napatama kurin, nabaa ratu i pasa'.

140 Napakenden di tammuan, ditadoi pising-pising.

141 Nabenni panampa to Bone, na pantari' to Balanda.

142 Naulang tama sepu'na, paiman ponno sepu'na, sende la'bi garopi'na.

143 Nabaa ratu ri tondok, paiman to torro $i$ tondok.

144 Napa'parampoi ringgi', napa'palin-palinanni.

132 pising-pising: plant met roodachtige bladeren van ronde vorm; vgl. pisik in $\mathrm{H} \mathrm{I}, 76$.

133 sumarre-marre: welig groeien als sarre = serai-gras, Anthropogon Nardus Linn.; dat gras heeft smalle, blauwgroene, geurige bladeren.

134 en 136 hebben betrekking op de maîskolven.

141 pantari', $1 \mathrm{t} 1$. hetgeen in een bepaalde vorm is afgesneden. 
129 Een belletje laat hij vooruit gaan, een luid gelach geeft de weg aan。

$130 \mathrm{Er}$ is gekwinkeleer aan zijn rechter- en linkerzijde, de ondiepe dalen verafschuwt hij.

131 De bergen zoekt zijn oog, daar stoot hij met een graafstok, die is als een lans met geitehaar.

$132 \mathrm{Hij}$ strooit er oude munten, het schiet er op als komkommer.

133 Welig is zijn groei als van het serai-gras, zijn uitspruitsels tieren als de bladeren van de prei.

134 Ze hebben lange rode pluimen, ze groeien van elkaar af, rechtstandig als jonge bamboespruiten.

135 En de volgende dag in de ochtend, draagt men het aan een draagstok als afval.

136 Men geeft ze over, ze zijn wit, maar geen witte reigers, en $z i j$ brengen ze naar het dorp.

$137 \mathrm{Zij}$ brengen het naar boven in het huis, $z i j$ versieren er het huis mee.

138 De zijkant van de haard ligt er tussen in, hetgeen overschiet gebruikt hij als voedsel.

139 Wat er overblijft van hetgeen hij in de kookpot doet, brengt hij naar de markt.

$140 \mathrm{Hij}$ brengt het opwaarts naar de marktplaats, men geeft hem er oude munten voor.

141 Men geeft hem het door de Bonieren geslagene, het door de Hollanders gemunte.

$142 \mathrm{Hij}$ keert ze om in zijn sirihtas, zijn sirihtas is verheugd, vol zijnde, zijn geldkistje, waarin meer zit dan het kan bevatten, is vergenoegd.

143 Hij brengt het naar het dorp, verheugd zijn de lieden, die in het dorp verblijven.

$144 \mathrm{Hij}$ doet ze bij de rijksdaalders, hij brengt ze over. 
145 Nasurrun lu tama uma, nasurrun lu tama tedong.

146 Natole tumangke i suru', suru'na tetean tampo.

$147 \mathrm{Na}$ masiang to makale', nalaoan ri bambana.

148 Nake'deran sulunanna, di pallaang-laanganna.

149 Umpemaelo alukna, umpesampa' garentena.

150 Giling-giling napadolo, lale' ummatai lalan.

151 Ia narannuan indo', mennaa'na marantena.

152 Lako nabassei tampang, nae'te'i balabatu.

153 Ungkombong tetean tampo, mammaranna pare sanda, pare ma'bana olinna.

154 Nasassang patuku ma'dandan, sola lampo' sielongan.

155 Sandami ponnoan alang, pantanmi la'bi panito.

156 Ia ma'kande silambi' ma'timbu' siratuan.

157 Nabaan membunga rangka', nabaa ma'lauk lamba'.

158 Natole tumangke i suru', suru'na lemba kalando.

159 Nalaoan ri bambana, nake'deran sulunanna, di pallaang-laanganna.

145 nasurmin: hij duwt ze voort, van kleine voorwerpen gezegd; The Chant, p. 53, IC, str. 84 bezigt in dit verband het woord nasukun, 1t1. hij dringt iets tegen iets aan.

148 en in 159 di pallaang-laanganna of di pellaang-Zaanganna? Het hs. is hier onduidelijk. (Red.)

151 indo' "moeder" heeft hier de betekenis van to indo' "de voorganger bij de rijstcultus". mennaa'na: het tegen de berghellingen gelegene, d.w.z. de gronden.

154 Zampo' zie op E IV, 14. 
$145 \mathrm{Hij}$ belegt ze in sawahs, hij belegt ze in buffels.

$146 \mathrm{Hij}$ gaat wederom een zoenoffer brengen, het offer voor het werk op de sawahs.

147 En de volgende dag in de ochtend, gaat hij van zijn erf af.

148 Dan vertrekt hij uit de afsluiting van zijn hof, uit de plaats, waar men zijn dorp in- en uitgaat.

$149 \mathrm{Zijn}$ adatvoorschriften goed volbrengende, de geluidsvoortekenen onderzoekende.

150 Een belletje laat hij vooruitgaan, een luid gelach geeft de weg aan.

151 Op hen is de verwachting van de voorganger bij de rijstcultus, de gronden tegen de berghellingen aan en die op de vlakte.

152 En heengaande hangt hij ze over het sawahvak, hij spant ze uit over de sawahdijk van opgestapelde stenen.

$153 \mathrm{Hij}$ maakt de sawahdijk in orde, de plaats, waar de rijst volledig rust, de rijst met allerhande lange aren.

$154 \mathrm{Hij}$ loopt tussen de stapels rijstbossen door, die in rijen staan, en de naar elkaar gebogen zakken van de bladschede van de arenpalm met gekookte rijst.

155 De rijstschuren zijn volkomen gevuld, elk der rijstbergplaatsen is meer dan vol.

$156 \mathrm{Hij}$ eet er regelmatig van, hij nuttigt ze wanneer hij gasten heeft.

$157 \mathrm{Hij}$ draagt ze aan als vrucht van de arbeid zijner handen, hij brengt ze aan in hoogte als de lamba'-boom.

$158 \mathrm{Hij}$ verricht wederom een zoenoffer, het offer voor de lange draagstok.

$159 \mathrm{Hij}$ gaat van zijn erf af, hij vertrekt uit de afsluiting van zijn hof, uit de plaats, waar men zijn dorp in- en uitgaat.

157 membunga rangka', 1t1. als bloem van de vingers verwerven. $m a^{\prime}$ Zauk = ma'lajuk: een hoogte hebben. ' Zamba' is een hoge boom, een ficus-soort.

158 Het offer voor de lange draagstok is het offer voor de geoogste rijst, die in de schuur is gebracht. 
160 Umpemaelo alukna, umpesampa' garentena.

161 Giling-giling napadolo, lale' ummatai lalan.

162 Tinti kanan kairinna, umpalumpa' gora tongkon.

163 Kajo malang dio mai langkan lumisu lu langan.

164 Ia narannuan indo', ia narannuan ambe'.

165 Natarrusan lian Mentang, anna mentangnga Larombo'.

166 Natadoi sanda'-sanda', nabenni tallunga-lunga.

167 Anna malang dio mai, ma'dondo nuang naturu'.

168 Busa' napaturusanni, natarrusan tama pasa'.

169 Anna mentangnga tammuan, umpatumbang bua uran.

170 Bambu nasisoronganni, tang nabungka' ke tang gandu.

171 Iami patalo tamben, to laan bambu disule.

172 Paimanmi ponno sepu'na, sende la'bi garopi'na.

173 To mai bulangan londong, iami patalo tamben.

174 Paimanmi ponno sepu'na, sende la'bi garopi'na.

175 Nabaa ratu ri tondok, napakenden ri pangleon.

176 Nasurrun lu tama uma, kabidangammi umanna.

177 Katampanammi teppe'na, disanga torro to sugi', anna tongkon to makaka.

177 Men kan de term to makaka het best karakteriseren met: een aanzienlijk vrij man met veel macht en invloed in de adatgemeenschap; zijn zonen en familieleden worden anak to makaka genoemd. 
$160 \mathrm{Zijn}$ adatvoorschriften goed volbrengende, de geluksvoortekenen onderzoekende.

161 Een belletje laat hij vooruitgaan, een luid gelach geeft de weg aan.

$162 \mathrm{Er}$ is gerinkel aan zijn rechter- en linkerzijde, hij laat de kiekendief vooruit gaan.

163 De grauwe reiger neigt naar hem, de kiekendief vliegt in kringen omhoog.

164 Op hem is de verwachting van de voorganger bij de rijstcultus gericht, op hem is de verwachting van het adathoofd gericht.

$165 \mathrm{Hij}$ gaat direct door naar de overzijde naar Mentang, en komt halverwege bij Larombo'.

166 Men reikt hem een weinig toe, men geeft hem hetgeen nict ruim voldoende is.

$167 \mathrm{Hij}$ wendt er zich van af, hij loopt hard, een bosantilope volgend.

168 Men laat hem gevolgd worden door de geheel witte, hij gaat direct door naar de markt.

$169 \mathrm{Hij}$ komt halverwege de markt, hij laat de hagel dansen.

$170 \mathrm{Hij}$ laat de bamboe geldpot heen en weer gaan, hij opent ze niet, als hij niet wint.

$171 \mathrm{Hij}$ wint bij elke beurt, wat in de bamboe is wordt omgekeerd.

$172 \mathrm{Hij}$ is verheugd, zijn sirihtas is gevuld, hij is vergenoegd, zijn geldkist is meer dan vol.

$173 \mathrm{Bij}$ het aanbinden van de kunstsporen beneden aan de sporen van de haan, wint hij elke keer.

$174 \mathrm{Hij}$ is verheugd, zijn sirihtas is gevuld, hij is vergenoegd, zijn geldkist is meer dan vol.

$175 \mathrm{Hij}$ neemt het mee komend in het dorp, hij brengt het in de nederzetting.

$176 \mathrm{Hij}$ belegt het in sawahs, de aaneenvoeging van zijn sawahs.

177 Het aantal van zijn sawahs neemt steeds toe, hij wordt geacht tot de rijken te behoren, hij is een gezeten to makaka. 
178 Inda ia la susinna,

la sipalinpa daona,

la pada tintiananna?

179 Umbaliangan ba'tangna, umbibi' pa'inaanna.

180 To maluangan ba'tangna, to malona' inaanna.

181 Maluangan anna sekong, malona' anna panura'.

182 To tang dilambi' passau'na, to mai pa'pana'ta'na.

183 To mai passau' bonginna, pa'panna'ta' dannari lambe'.

184 Ussau' sangtondokna, umpana'ta' sangbanuanna,

185 ke umpalalloi aluk, umpatidonni bisara.

186 Te dio rampe matampu', daa tanete nabuni.

187 Daa lombok naparerung, natananni tang marapo.

188 Unnosok tang melu'-melu', nenne' sitontongan allo.

189 Untanan bua lauk, induk mekasiri'-siri'.

190 Nasangkinni bete tondok, biladong sa'de banua, seba randan matakali.

191 Mangnga-mangnga sangdatunna, leaga sangkaraengna,

192 ke napapatui lako, ke naolan-olananni.

193 Ditambai indo' tondok, rampomi pangulu salu.

183 dannari is de tijd die ligt tussen middernacht en het ochtendkrieken, ongeveer 3 uur in de nacht; dannari lambe': de tijd na middernacht, na welke het nog lang duurt voordat de vroege morgenstond aanbreekt.

188 sitontongan allo, 1tl. die er altijd te zamen zijn met de dagen.

189 Met induk mekasiri'-siri', "de aren-palm, die geëerd wordt", wordt de arenpalm bedoeld die op de feestplaats van het doden- 
178 Wie zou dan zijns gelijke zijn, zou even verheven zijn als hij, zou hem evenaren?

$179 \mathrm{Hij}$ keert zijn innerlijk om, hij wendt zijn gedachten om.

180 Een grootmoedig iemand, iemand ruim van hart.

181 Ruimer dan een haakse figuur, wijder dan een figuur van het snijwerk.

182 Iemand wiens op en neer gaande gedachten niet te achterhalen zijn, de regelingen, die hij treft.

$183 \mathrm{Er} z i j n$ zijn op en neer gaande gedachten in de nacht, zijn regelingen in de uren na middernacht.

$184 \mathrm{Hij}$ heeft macht over het gehele dorp, hij strekt zijn regelingen over al zijn buurtgenoten uit,

185 wanneer hij de adatverrichtingen eigenmachtig regelt, de luister van de riten van de adat voor de doden opvoert.

186 Die aan de Westzijde, op het gebergte in het Noorden verbergt hij.

187 Die in het dal in het Noorden beschermt hij, hij stelt in die niet vergaan.

188 Hij plant ze die vast blijven, die steeds door er zijn, zo lang de dagen er zijn.

189 Hij plant de verheven vrucht, de aren-palm, die geëerd wordt.

$190 \mathrm{Hij}$ bindt er de buffels aan vast, de karbouwen die hij bezit, de apen aan de rand van de opening van de wal van het dorp.

$191 \mathrm{Zijn}$ mede-edelen zijn verwonderd, zijn mede-karaengs zijn verbluft,

192 wanneer hij het hun opdraagt, wanneer het gaat volgens hetgeen reeds geschied is.

193 Dan worden de adathoofden geroepen, de hoofden van de rivier verschijnen.

feest geplant wordt naast een der opgerichte, in bepaalde vorm gehakte stenen (simbuang induk); aan die aren-palm wordt een der te slachten buffels gebonden.

190 bete tondok, 1tl. de vissen (ikan gabus e.s.v. Ophiocephalus) van het dorp.

biladong sa'de banua, 1t1. de zeevissen van het erf van het huis. 
194 Nangka' sangsese nabenni, durian sisaman ta'pa'.

195 Kande tang nakautangi, la'ka' langngan lingarona.

196 Nenne' napengkilalai, nasulean dao mai.

197 Napoloo sambalin mai, umpemasero tondokna,

198 umpepindan banuanna, naanta' sembangan ongan.

199 Te dio rampe matampu', ia napekanene'i, bendanmi tantanan pusuk.

200 Maseromi banuanna, tang sangbulan namasero to indanna, maborong rampe matampu'.

201 Anna la denda susinna, la pada tintiananna?

202 Umpapada-pada aluk, umpasitinti bisara.

20.3 Iami manglau' eran, ia ma'kanna pelalan.

204 Natole tumangke i suru', suru'na sembangan ongan.

205 Suru'na demmeran para, suru'na surasan tallang.

206 Suru'na bate manurun, suru'na raukan tedong, suru'na tananan bua'.

194 De nangka-vrucht heeft een dikke, stekelige schil met grote pitten, waar omheen geel, zoet vruchtvlees zit, Artocarpus integrifolia. De durian-vrucht heeft een dikke, stekelige schil, met grote pitten, waar omheen een sterk ruikend vruchtvlees zit met de smaak van uien, Durio zibethinus. - Deze strofe geeft te kennen, dat bij het slachten van dieren op een feest de adathoofden het hun volgens de adatvoorschriften toekomende gedeelte van het geslachte wordt toegekend.

198 De vertaling lijkt onvolledig of onjuist, vgl. de weergave van sembangan ongan in str. 204. (Red.)

205 demmeran para, 1t1. neerleggen op het rekje aan de wand aan de Noordzijde van het huis, of ma'parekke para, 1tl. Noordwaarts brengen naar het rekje boven de haard, is de benaming van een offer van een varken aan de goden, dat in huis wordt geofferd. 
$194 \mathrm{Hij}$ geeft hun een halve nangka-vrucht, een echt even groot deel van een durian-vrucht.

195 Voedsel waarvoor men geen schuld oploopt, dat aan hun gehemelte kleeft.

196 Voortdurend heeft hij het in gedachten, hij keert er van boven naar terug.

$197 \mathrm{Hij}$ gaat van de overzijde hierheen om zijn dorp te reinigen,

198 om zijn buurtschap te zuiveren, hij geleidt het brengen van offers.

199 Die aan de Westzijde, die noemt hij voorvaderen, toen geschiedde het offer, waarbij de jonge bladeren van de suikerpalm uiteen werden gehaald en aan een bamboestaak werden bevestigd.

200 Zijn buurtschap was rein, het duurde geen volle maand en toen was zijn schuld aangezuiverd, zijnde het gebied van het Westen.

201 zou er zijns gelijke zijn, zou er een zijn, die hem evenaarde?

202 Om de offerverrichtingen van gelijke waarde te doen zijn, de adatinzettingen met elkaar in evenwicht te houden?

$203 \mathrm{Hij}$ volgde de treden van de trap, hij betrad de sporten van de ladder.

204 Wederom volbracht hij het zoenoffer, het zoenoffer van het afhakken van de schaduwtakken.

205 Het offer van het demmeran para, het offer van het surasan tallang.

206 De riten van de bate manumun, de riten van het steken van de buffel, de riten van het bua'-feest.

surasan tallang, 1tl. het insnijden van figuren in dunne bamboe, is de naam van een offer op een offerstelletje in welks poten figuren gesneden zijn; vgl. tekst A, p. 430, nt. 76 .

206 bate manumun, $1 \mathrm{tl}$. neergedaalde bamboestaak, is de naam van een bij het maro-feest opgerichte bamboestaak met een lange rode doek er aan; aan het uiteinde van de staak is rijst bevestigd en aan het midden hangen enige zwaarden. Het offer van het raukan tedong: steken van de buffel, is het merok-feest.

tananan bua', 1tl. "het planten van het bua'-ritueel" is het vieren van het bua'-feest. 
207 Bai saratu' natunu, sangsa'bu napemalaran.

208 Rampomi piso digallang, to laan tangngana tondok.

209 Manga-manga sangdatunna, leaga sangkaraengna.

210 Nangka' sangsese nabenni, durian sisaman ta'pa'.

$211 \mathrm{Na}$ kami to minaa, dipalonto'i kande tang kikautangi.

212 Sumalidondo serre'ki, unnuduk busarungngu'na.

213 Kipepasal lo bupangden, kipesuke buandelen, ki tambuk ma'datu-datu.

214 Anna la denda susinna, la sipal inpa daona?

$215 \mathrm{Ke}$ dipebambai tondok, ke diesse'i sulunanna,

216 bala salli'na pangleon, salli'na babanganta.

217 Ke den tanete marontan, lombok tita'gena'-gena',

218 untananan tuan rondon, umbangke' tigena'-gena'.

219 Untimang batu melenten, tuan napasule langngan.

220 Merrandanan talo bendo', mellombok sesse buaa.

221 Umpasirri' issi salu, buaja mallai bongi.

222 Pakabua'na sandoki, pa'kasolang-solanganna,

208 piso digallang, 1t1. de messen, die een band hebben van messing. 210 zie nt. bij str. 194.

215 diesse' $i$, 1tl. wordt vastgebonden.

216 bala salli': een omheining van gespleten bamboe, die schuin gekruist gevlochten is.

220 buaa, elders buaja: krokodil. 
207 Honderd varkens slachtte hij, duizend slachtte hij er bij de offers.

208 Toen kwamen de aanzienlijke lieden, die in het midden van het dorp verblijven.

$209 \mathrm{Zijn}$ mede-edelen zijn verbaasd, zijn mede-karaengs zijn verbluft.

$210 \mathrm{Hij}$ geeft hun een halve nangka-vrucht, een echt even groot deel van een durian-vrucht.

211 En ons to minaa

wordt een groot deel van de spijzen toebedeeld, dat als niet geleend wordt gerekend.

212 Onze kat komt toelopen, de heerlijke geur ruikende.

$213 \mathrm{Wij}$ zoeken een bamboekoker met deksel voor hetgeen geurt als het pangden-gras, wij zoeken een bamboegeleding voor hetgeen geurt als andelen-gras, wij doen het in onze schoot als zijnde van uitstekende hoedanigheid.

214 Zou er zijns gelijke zijn, in de kring waarvan de een de ander in hoogheid overtreft?

215 Wanneer de toegang tot de nederzetting overvallen wordt, wanneer de toegang tot het dorp in de hand is van de vijand,

216 is hij de omheining van de nederzetting, is hij de grendel van de toegang tot ons dorp.

217 Wanneer er bergengrote onrust is, woelingen diep als ravijnen,

218 dan maakt hij een beplanting voor hetgeen is neergestort en neergevallen, en maakt een beschoeiing tegen hetgeen wankelt.

219 Rollende stenen vangt hij op, het afgestorte brengt hij weer opwaarts.

220 Loopt hij langs een oever, hij is het watermonster de baas, loopt hij door het dal, dan vat hij de krokodil aan.

$221 \mathrm{Hij}$ vervolgt de geest van de rivier, de krokodil vlucht weg in de nacht.

222 Door de daden van onze vriend, door zijn verschrikkelijk doen, 
223 tamuka' bembe natingkan, solo' tanduk narabekki.

224 Da'dua natumpu tuka', a'pa' narassai solo'.

225 Pitu naambe pakolong, paiman disialla'i.

226 Sende disiparra'i, tang tioton pariona.

227 Paimanmi gandangna, sendemi bombonganna.

228 Napa'parampoi arre, napa'pal in-palinanni.

229 Tang pada mannapa to, ke nasange'-sange'oi, ke napakataranoi.

230 Ke siada'i gandangna, sikuanni bombonganna.

231 Daa tanete makati', daa lombok beuaran.

232 Rekke narotoi sinding, naparu'tungi balulang.

$233 \mathrm{Na}$ masiang to makale', nakapana'-panaranna,

234 male matin tang memanuk, tang ussopatian langkan.

235 Talimpuru' nadoloi, angin natondai lako, urrabekki baladada' .

$236 \mathrm{Ao}^{\prime}$ kumpang tama tondok, totiang kakumbaa'-baa'.

237 Ia naola manglelleng, napolalan ma'uasei.

238 Ungkabumbuk to ma'lambuk, ampang napa'palinda'i.

239 Lao' sumbung dolo tantang, dao palangka merena'.

223 De bedoeling van deze strofe is, dat de vijand, die vluchtend nederwaarts gaat, van achteren aangegrepen wordt en achterover valt. 
223 gaat de statielans, die hij gegrepen heeft, omhoog, zinken de horens, die hij van achteren los gerukt heeft, neer.

224 Twee duwt hij omhoog van zich af, vier slaat hij met de voeten omlaag.

225 Op zeven legt hij de hand als ware het een rugbedekking, tevreden dat er ruimte tussen gehouden wordt.

226 Verheugd dat er een afstand tussen gesteld wordt, het einde van zijn lendendoek raakt er niet ingedompeld.

$227 \mathrm{Zijn}$ trom is tevreden, zijn gong is verheugd.

$228 \mathrm{Hij}$ laat er juichkreten over horen, hij doet die de een de ander verdringen.

229 Zijns gelijke is er nog maar niet, wanneer hij het weer slijpt, wanneer hij het weer aanscherpt.

230 Wanneer hij en zijn trom het elkaar leren, hij en zijn gong het elkaar zeggen.

231 In het Noorden op de heuvel is het onrustig, in het Noorden is het dal vol jeukte veroorzakende kruipplanten.

232 Stroomopwaarts legt hij her en der hinderlagen, drijft hij het in het schild.

233 En de volgende dag in de ochtend, wanneer de zon brandt,

234 gaat hij er op af zonder naar de voortekens te kijken, zonder zich te bekommeren om het teken van de kiekendief.

235 Hij loopt voor de wervelwind uit, hij stuift de wind voorbij, hij rukt de recht opstaande omheining omver.

236 De dikke bamboe buigt het dorp in, de jonge bamboetakjes wiegelen heen en weer.

$237 \mathrm{Hij}$ betreedt het ze omhakkend, hij neemt zijn weg er al werkend met de bijl.

238 Haastig gaande naar hen, die rijst stampen, gaat hij de drempel regelrecht over.

239 Het vertrek in het Zuiden verlaat hij eerst, in het hoger gelegen vertrek zoekt hij de ongestampt gebleven rijstkorrels. 
240 Ta'pian sikano utak, barra sikappalu' rara.

241 Sikarupepean siruk, sikarrakan kara kau.

$242 \mathrm{~Pa}$ 'kabua'na sandoku, pakasolang-solanganna.

243 Nasulean dio mai, anna lamban diong salu, anna mentete uai.

244 Nakua kada to Duri, randan pudukna to Endekan:

245 "Anna malutura salu, anna borrongra uai.

246 Pangotonan dokena lalong, pangoton tappu arena."

247 Nasulean dio mai, napole sambalin mai.

248 Iko to torro i tondok, tau kenden dipangleon,

249 rampanangko tannunmu, annako pa'kalarammu.

250 Ammu ma'kundai ani', muma'rombe bala'ba'.

251 Napotamba' pia'-pia', anna malompo a'rari.

$252 \mathrm{Na}$ masiang to makale', tang umpopentaruk tallang.

253 Tang umpopellolo induk? Nasembang napobala'ba'.

254 Tallang sanglampa nasura', sangparaan naanggilo.

255 Sangpati' nabua pana', napatondon daro-daro.

256 Bai tandesse' natunu, bai $1 e^{\prime} k a n g$ napararuk.

241 kara kau, elders kara kaju: houten pollepel.

248 Het pronomen van de $2 \mathrm{e}$ persoon enkelvoud iko wordt ook gebruikt in een aanspraak tot een menigte.

250 ani'; dit woord is aan de Heer Tammu niet bekend. 
240 Het kaf wordt gekookt te zamen met de hersenen, de ontbolsterde rijst, vermengd met bloed, zodat ze aaneen kleeft.

$241 \mathrm{Er}$ is een groot lawaai van de lepels, een groot geraas van de pollepels tegen elkaar.

242 Het zijn de daden van mijn vriend, zijn verschrikkelijk doen.

$243 \mathrm{Hij}$ keert er van terug, hij steekt de rivier over, hij loopt over het water.

244 De woorden der Duriërs luiden, uit de rand der lippen der Enrekangers klinkt het:

245 "De rivier is er troebel van, het water is er erg rood van.

246 Het is het indompelen van de lans van de held, het indompelen ten einde toe van zijn kin."

$247 \mathrm{Hij}$ keert er van terug, hij komt weer terug van de overzijde.

248 Gijlieden, die verblijft in het dorp, gij, die in de nederzetting opstijgt,

249 laat uw weefsels liggen, bergt op uw gerei om de scheringdraden uiteen te houden.

250 Dat gij u kleedt met een rok ..., dat gij $u$ tooit met de franjes van de bladeren van de arenpalm van welke de nerven ineen gekronkeld zijn.

251 Dat de kleine kinderen het bezigen om het bloed te stelpen, dat de vliegende mieren vet worden.

252 De volgende dag in de ochtend, had de bamboe geen spruiten.

253 Had de arenpalm geen loten?

Men had ze afgehouwen om ze als ineengekronkelde bladeren te bezigen.

$254 \mathrm{Hij}$ grift figuren in een bamboegeleding,

hij snijdt figuren uit in een gedeelte.

255 Eén stuk maakt hij tot een vlechtsel als de vrucht van gember, hij legt een doek uit verschillende lappen bestaande aan de rand er van.

$256 \mathrm{Hij}$ slacht een klein, gaaf varkentje, een varken met dikke buik offert hij op een offertafeltje. 
257 To massadi daa buntu, ma'pararuk daa tanete.

258 Tabang tang balle naserek, lassege' tang kira-kira, bulaan tiseno diong.

259 Metamba rekke ri puang, meongli' rekke deata, sae pantan siruk tabang.

260 Tappu tanete natendeng, lombok nakundala-dala.

261 Turun tongan daa mai, tae' dikita lumalle.

262 Tang kojong passirukanna, ampu lembang lan di to'na.

263 Karaeng lan kurapakna, ia umpakamangkai.

264 To minaa sia pira, ia umpakamangkai sesa isinna deata, ra'dak panamma-nammana.

265 Nasulean daa mai, napole sambalin mai.

266 Unnanna kande limanna, sola timbu' tarunona.

267 Nadandanan rekke annan, nabate' rekke karua, sikatadisi-disian.

268 Napobaine manuntun, napoka'din simadoan.

269 Pare kamban dao langi', pare natangko deata, 270 napamili' to menampa, kutu' kasallena puang, pori kangkanna deata.

260 Het afzetten van een plaats met bamboestokjes heeft ten doel aan te geven dat die plaats taboegebied is.

267 sikatadisi-disian, 1tl. aan alle zijden worden de tanden zichtbaar bij het lachen, vgl. sitaradisi-disian in H II, str. 54; de woorden zijn verwant met isi: tand. 
257 Degene, die het te offeren vlees in kleine stukjes snijdt, is in het Noorden op de berg, degene, die offert, is in het Noorden op het gebergte.

258 Echte Dracaena-bladeren scheurt hij, onbedriegelijke drakenbloedblaren, gezeefd goud is daar.

$259 \mathrm{Hij}$ roept Noordwaarts de goden aan, hij roept Noordwaarts tot de geesten, dat ieder kome om van de Dracaena-bladeren op te scheppen.

$260 \mathrm{Hij}$ looft alle bergen tot de laatste toe, hij zet de dalen met gespleten bamboestokjes af.

$261 \mathrm{Zij}$ dalen waarlijk van het Noorden af, men ziet niet, dat $z i j$ er in bijten.

262 Het opscheppen tast het niet aan, der grote heren in de oorsprong.

263 De goden in de vertakkingen, zij maken het op.

264 Er zijn ook enige to minaa, zij maken op hetgeen uit de tanden der goden overbleef, het restant van hetgeen door hun keel ging.

265 Hij keert er van terug, hij komt weer terug van de overzijde.

$266 \mathrm{Hij}$ bewaart het voedsel door $z i j n$ handen verworven, en de spijze door zijn vingers verkregen.

$267 \mathrm{Hij}$ stelt het Noordwaarts op in rijen van zes, hij rangschikt ze Noordwaarts in rijen van acht, terwijl hij gul aan het lachen is.

268 De wespen trouwen er mee, de wespen met een dun middellijf huwen or mee.

269 Een menigte rijst is er in het uitspansel, rijst die de goden opbergen,

270 die de schepper ophoopt, de grote bossen van de heren, het samengebondene van hetgeen de goden geoogst hebben. 
271 Kubelengan gualinna, kuto'mok lumpa-lumpana.

272 Ia kurambi tagari, kubangunan diong mai.

273 Bakkun balusu oranna, melenten situang lemba, ta'pa lan tangngana uma.

274 Pare sangsa'pe dilullu', karua baka bannena.

275 Tang sangbongi sia diong, anna tarru'mo uai, sumarre-marre lobo'na.

276 Piranmoki' la mantanan anta allu' sangtondokta, tukuan sangbanuanta.

277 Ditanan darang-darang, sumarre-marre lobo'na.

278 Sulemo' untiro pare, ullinde-linde kinande.

279 Kusanga oto'na tille, anna oto'na pareta.

280 Reu apapara lan, mangkamo natorak lendong?

281 Napentombang kiru-kiru kajo pesanda uai, sekke' to mambaa se'pon.

282 Sulemo' untiro pare, ullinde-linde kinande.

283 Kusanga bassunna biang, anna oto'na pareta.

284 Bulaan napangidenni, rara' natukkunan rokko.

285 Aluk-aluknara tondo, anna die'te'i tinting, dipapandanni rembasan.

279 tizle is de rietsoort, Andropogon halepensis Stapf.

281 sekke': een vogel met grote kop en lichtblauwe veren en wit aan de hals en de kop. 
271 Ik sla hun luik naar boven open, ik zet mijn vingertoppen op hun deur.

272 Ik laat er de rook van welriekend kruid over heen gaan, ik til ze van beneden af op.

273 Als witte schelparmbanden zijn de rijsthalmen met de aren er in, ze dragen ze aan de draagstok, ze blijven staan in het midden van de sawah.

274 Eén halm wordt gedorst, acht korven is het zaaizaad er van.

275 Het is er nog niet een gehele nacht, en regelrecht is er water, de groei er van is welig als die van het serai-gras.

276 Wànneer zullen wij gaan planten, opdat wij de tijd bepalen voor onze dorpsgenoten, en het zeggen aan onze buurtgenoten?

277 Ze wordt wijd uit elkaar geplant, ze groeit welig als het serai-gras.

$278 \mathrm{Ik}$ ben teruggekeerd om de rijst te bezien, om het voedsel nauwkeurig te beschouwen.

$279 \mathrm{Ik}$ dacht, dat ze de ondereinden waren van rietstengels, en het waren de ondereinden van onze rijsthalmen.

280 Wat zou er nog voor gras tussen zijn, nu de aaltjes het al gewied hebben?

281 De sawah-visjes wentelen er zich in de modder, de grauwe reiger regelt het in- en uitstromen van het water bij

de uitgang van het sawah-water, het sekke'-vogeltje wiedt het ondereind van de sawah-dijk.

282 Ik ben teruggekeerd om de rijst te bezien, om het voedsel nauwkeurig te beschouwen.

283 Ik dacht, dat het de zwelling van het vrucht zetten van het pijlriet was, en het was het ondereinde van de rijststengel.

284 Naar goud gingen haar lusten uit, naar een halssieraad boog zij zich neer.

285 Het zijn de adatinzettingen voor haar daar, dat er over haar een lijn gespannen wordt, dat er over haar een bamboestaak wordt uitgestrekt. 
286 Dikua anna madomi', anna ma'tikara-kara.

287 Matasakmo sangrandanan, ro'pomo sangsalu rekke.

288 Sangsalossok daa mai, matasak asangmo pare.

289 Piranmoki' la mepare, anta allu' sangtondokta, to mai sangbanuanta.

290 Tampangki' kondo, diba'tan bete inanna.

291 Mangnga-mangnga to ma'pasa', leaga to ma'tamman.

292 Nasanga bintoen ronno', allo tobang dao mai, anna sarong to mepare.

293 Tang sangkuan lian, anna la botomo bongi.

294 Kendek ussamboi buntu, tang umpasombo kalebu'.

295 Banne ba'tang to ma'pasa', ke naissanni naia', ke napulo-puloanni.

296 Tang meongan to ma'pasa', lolok lampo' napoongan.

297 Patuku naporerung, sandamo natoe pongo'.

298 Piranmoki' 1a manglemba, anta allu' sangtondokta, to mai sangbanuanta.

299 Tallu ratu' sangke'deran, sangsa'bu sangtiangkaran.

300 Misa to manglemba pusa, lu tama to' tadolloan, urruru ponto bulaan.

295 banne ba'tang zie op H I, 36, en vgl. banne manarang: de bekwame mensensoort. 
286 Opdat het vlug mag gaan, het heel vlug mag geschieden.

287 Rijp is ze op de sawahs, die tegen de rivieroever zijn gelegen, heel rijp op de sawahs, die zich uitstrekken in een reeks in een vallei, die de vorm heeft van een stroom.

288 De sawahs aan de voorzijde van het ravijn, daar is alle rijst rijp.

289 Wanneer zullen wij gaan oogsten, opdat wij de tijd bepalen voor onze dorpsgenoten, voor onze buurtgenoten?

290 Smeed ons een groot hakmes, waarmee het grote moederdier van de bete-vis doorgehakt wordc.

291 De marktgangers staan verwonderd, de mensen die naar de pasar gaan zijn verbluft.

$292 \mathrm{zij}$ menen, dat de sterren omlaag zijn gevallen, dat de zon is neergestort, en het zijn de zonnehoeden van hen, die rijst oogsten.

293 Men zal niet in éénmaal klaargekomen naar de overzijde gaan, en het zal zijn, dat de nacht zal neerzinken.

294 Hij rijst op en bedekt de bergen, hij maakt de aardhoop in de sawah onzichtbaar.

295 Het moet wel het nakroost van de scherpzinnigen der marktgangers zijn, wanneer zij ze weten te berekenen, wanneer zij ze bij tientallen tellen.

$296 \mathrm{Zij}$, die ze in bossen van vijf bijeen binden, ontkennen het niet, zij gebruiken als plek van schaduw de grote, kegelvormige zak van de bladschede van de aren-palm met gekookte rijst er in.

297 De opgestapelde rijsthopen bezigen zij als beschutting, voltallig zijn de bossen van vijf, die zij ter hand nemen.

298 Wanneer zullen wij ze op de schouder gaan dragen, dat wij het met onze dorpsgenoten gaan afspreken, met onze buurtgenoten?

299 Drie honderd gaan te zamen op stap, duizend gaan te zamen vertrekken.

300 Eén, die rijst op de schouder draagt, raakt verdwaald, hij komt terecht in de open plaats op de sawah-dijk, waar het water afvloeit,

hij raapt op de weg een gouden armband op. 
301 Iko to torro i tondok, tau kenden di pangleon,

302 bintanmoko sali alang, la dipa'parampoi pare, dipa'palin-palinanni.

303 Sangbassanan angge rinding, sangkutu' unnala papa, memanna sangkinan rinding.

304 Nakua kadanna datte', randan pudukna mandoti:

305 'Lo'bang-10'banganna' sidi', palempe sangpiakanna'.

306 Da' angku kakei rinding, da' kuso'boi manangnga."

307 Nakua kadanna barri, randan pudukna kumua:

308 'Tau tambingmoko, datte', dinasuan to saena, sola to massaroanna.

309 Umbanni batu ianan, sola balo' karambau."

310 La napandan anna sugi', naanna anna lellua.

311 Apaopa to muanga' natuntun lan inaammu, naporainda-indamu?

312 Manukmuraka la tae', ke 1 ao rokko i bamba.

313 Ke diongi kakendenan talo barra' kaluppini', ke sipendurukanni.

304 randan pudukna mandoti, $1 t 1$. de rand der lippen van de donkerbruine langharige kleefrijst.

308 De betekenis van deze strofe is, dat de rijstschuur zo vol is, dat er voor de rode rijst geen plaats is en die in de aanbouw geborgen wordt.

311 In de vorm naporainda-indamu: "het door u steeds verlangde" is de reduplicatie toegepast op de laatste twee lettergrepen van het woord naporainda, hetgeen is samengesteld uit de verbale vorm naporai, aan welke het vraagpartikel nda is gehecht; achter de aldus geredupliceerde vorm is het possessieve pronomen van de $2 \mathrm{de}$ persoon enkelvoud -mu gevoegd. 
$301 \mathrm{Gij}$, die in het dorp verblijf houdt, die opgaat in de nederzetting,

302 bindt de vloerlatten van de rijstschuren stevig vast, om de rijst er heen te laten komen, ze er heen over te brengen.

303 Ze worden in één keer neergelegd even hoog als de wanden, één enkele bos raakt al de dakbedekking, de brede stijlen aan de wand, waarin de houten platen van de wand geschoven worden, kraken.

304 Het woord van de rijst met rode huid luidt, uit de mond van de donkerbruine langharige kleefrijst komen de woorden:

305 "Maakt mij een weinig ruimte, helt wat aan de ene zijde voor mij neer.

306 Opdat ik niet de wand stuk make, $i k$ een gat drijve in het middenvak."

307 Het woord van de rijst, die rode gestampte korrels oplevert, luidt, uit zijn mond komen de woorden:

308 "Je bent het deel voor de mensen van de aanbouw naast de schuur, rijst met rode huid, je wordt gekookt voor de gasten, en voor de lieden die voor loon komen werken,

309 het wezenlijke van de bezittingen aanbrengend, en een weelderig bezit aan buffels."

$310 \mathrm{Hij}$ moet ze bewaren, opdat hij rijk worde, hij moet ze opbergen, opdat hij overvloed van welvaart hebbe.

311 wat dan verder zoekt gij nog, hetgeen in uw hart nagejaagd wordt, hetgeen door $u$ ten zeerste begeerd wordt?

312 Zouden er geen hoenders van $u$ zijn, wanneer men naar de ingang in het dorp gaat?

313 Wanneer zij op de plaats zijn, waar men naar het dorp opgaat, leggen de zwaluwen het bij hen af in het bemachtigen van ontbolsterde rijst, wanneer zij te zamen naar voedsel zoeken. 
314 Manuk lotong tang menna'tong rame mangassai manna.

315 Meberada' tungga' la'bo', mebu'ku' tallu uase.

$316 \mathrm{Na}$ iato rame, mengkaro bu'tu bulaan.

$317 \mathrm{Na}$ iato londongna, ma'kukkua sae tedong, kotok renden penamile.

318 Minda ia la susinna, la sipalinpa daona?

319 Sibiongan asu rangnganan, mogon-mogon bai tora.

320 Doko sirante paladan, ma'pal isu palunganna, rongko' pesangle bainna.

321 Tang membulan-bulan ia, anna tungga' penamile.

322 Minda ia la susinna, la sipal inpa daona?

323 Tedong marapu ri Mentang, mokurungan di Endekan.

324 Rokko dikambio santung, dika'bi' pa'pairusan.

325 Talo dondan diong mai, tallu ratu' sangke'deran, sangsa'bu sangtiangkaran.

326 Dolo pampang undi pampang, tarangga lan leu tangnga, misari bulan merrau.

327 Tanda pasangnara to, ke baliang tamba sola.

315 "zoekt men er een", nl. een kipje.

317 Deze strofe bevat een zinspeling op de haan van Lapandek, zie H I, str. 12.

320 De betekenis van regel a is, dat de zeugen zo groot zijn, dat ze in hun hokken, die zich in de uitgeholde grond bevinden, toch reiken tot de oppervlakte van het erf. Wervelfiguren in de etensbakken der varkens zijn een teken, dat de varkens goed zullen gedijen.

323 In The Chant, p. 53, IC, str. 87 luidt de plaatsnaam Buntang. 
314 De zwarte hoenders hebben geen enkel ei, waar geen kuiken uitkomt, de gele hoenders met bruine spikkels doen niet anders dan door het ei heenbreken.

315 Zoekt men er een van de grootte van een klein vogeltje met grijsachtige en witte veren, dan is die éên hakmes waard, zoekt men er een van de grootte van een bosduif, dan is die drie bijlen waard.

316 Het hoen met gele veren, bruin gespikkeld, krabt in de grond, dan verschijnt er goud.

317 En wat zijn haan aangaat, hij kraait en er komen buffels, kakelt hij, dan trekt hij de buffelstieren achter zich aan.

318 Wie zou zijns gelijke zijn, hem in verhevenheid evenaren?

319 De jachthonden lopen in menigte maar rond, de zwijnen met grote slagtanden puilen uit van vet.

320 De zeugen reiken tot het niveau van het erf, hun etensbakken hebben wervelfiguren, de scheplepels voor de varkens zijn fortuinlijk.

$321 \mathrm{Hij}$ krijgt geen albino buffels, het zijn enkel buffelstieren.

322 Wie zou zijns gelijke zijn, wie hem in verhevenheid evenaren?

323 De buffels zijn er in kudden in Mentang, zij zijn in kralen bijeen in Enrekang.

324 Met een signaal worden $z i j$ naar beneden geroepen, zij worden gewenkt naar de drinkplaats.

325 In groepjes spoeden $z i j$ zich vandaar voort, drie honderd gaan te zamen op stap, duizend gaan te zamen vertrekken.

326 De eerste en de laatste zijn buffels met recht gestrekte horens, de buffels met recht opstaande horens, in het midden, een enkele licht gekleurde buffel er bij.

$327 \mathrm{Hij}$ is het kenteken van de kudde, wanneer er een buffel is, die slechts aan éên zijde haarwervels heeft, roept hij de gezellen.

324 De str. 323-325, 326-327a en 329 zijn ongeveer gelijk aan die in The Chant, p. 53, IC, str. 87-89, 91v. en 97. 
328 Ke rokkok rombe baana, napotedong to melada'.

329 Tedong tang mate anakna, tang marantan sumanga'na.

330 Tedong ma'inaa tau, sipaela' ke kadakean.

331 Iko to torro i tondok, tau kenden di pangleon,

332 bettengko dua buntu, rompoko tallu tanete, la dipa'parampoi tedong.

333 Sangtondok metaruk biang, sangsaroan meballa mangura.

334 Sangkaroen sangrundusan, melambi' sangkianakan.

335 Tallu ratu' nedo'-nedo', sangsa'bu lundara'-dara' .

336 Tedong manoka didaa, tang ma'din dikira-kira.

3.37 Iapi anna mellao, anna tumengka i sullu',

338 tampak bunginpi nalese, rangka' kadoke-dokean.

339 Tang nauma ke marangkei, ke nakalangkai kalo',

340 kalimbuangpi se'ponna, saruran tiku biringna.

341 Uma malompo masapi, na iato lakinna.

342 Tedong ma'din dipassalagan, dipapandanni aoka.

328 rokkok is een buffel, die een wervel aan de horens heeft en zodoende van lagere waarde is.

333 sangsaroan: groep van lieden uit een buurtschap, die gemeenschappelijk werk bij de akkerbouw verrichten.

335 nedo'-nedo' ( $=$ ne'do-ne'do) is een nevenvorm van tedo'-tedo', verkleinwoord van tedong: buffel.

338 De betekenis hiervan is, dat die buffels slechts gebruikt worden om er sawahs met weke grond voor te kopen. rangka' kadoke-dokean, 1t1. vingers bedekt met doke-doke planten. De doke-doke planten groeien goed in waterrijke sawahs. 
328 Wanneer de buffels, die een wervel op de horens hebben, veel jongen hebben, kunnen de jongeren, die de bezittingen leren te beheren, die in hun bezit krijgen.

329 Buffels, wier jongen niet sterven, wier nakroost niet afneemt.

330 Buffels wier geest is als van een mens, die langs een steilte voorzichtig gaan.

331 Jullie, die in het dorp woont, gijlieden, die in deze streek $u$ beweegt,

332 legt een schans om twee bergen, omheint drie gebergten, dat de buffels er heen geleid worden.

333 Over het hele dorp spruit het pijlriet uit, zo ver als de hele gemeenschap reikt eten ze de jonge grasspruiten, die opkomen na het afbranden van de grasvlakte.

334 De gehele avond geschiedt het bespringen, de gehele ochtend jongen zij.

335 Driehonderd buffelkalveren zijn er, duizend jonge buffelwijfjes.

336 Buffels, die niet met list behandeld willen worden, die niet bedot kunnen worden.

337 E1ke keer dat zij uitgaan, dat $z i j$ van de afsluiting voortschrijden,

338 betreden $z i j$ de zachte grond, waar de vingers vol raken met doke-doke-planten.

339 Hij legt geen sawah aan, wanneer de bodem droog is, wanneer de watergoot ver weg is,

340 slechts wanneer de voet van de helling van de sawah-dijk een bron is, wanneer er waterleidingen zijn rondom de kanten er van.

341 Een sawah, vet als een paling, dan is het met zijn stier.

342 De buffels kunnen gebruikt worden voor het eggen, zij worden opgesteld aan een juk.

342 aoka is de in de NW streken van het Rantepaose gebezigde vorm van het elders luidende ajoka: "juk". De ploeg en de eg worden door een juk buffels getrokken. 
343 Dolo tandukna massese, ikko'na mangkali ada'.

344 Ke den kalimbaun lumbang, nasalembe' kalungkungna.

345 Natodo tappu arena, sali papanmo umanna.

346 Lendu' rokko makatanna, kendekmi kapareanna.

347 Mindao ia la susinna, la sipal inpa daona?

348 Kaunanopi to kulambi', kaunan sambali' Aa'.

349 Sirupang sengke Patundu', untappele' kaunanna.

350 To dipalempe dapo'na, tipalin sambalin mai.

351 Tarru'ru' sau'ko sumbung, ke lao'i anginan.

352 Ditadoi pangngan noka, diben sambako unniling.

353 Sae mekapuungora, diribang-ribangan le'ke'.

354 Di la'bakan pare pulu' misari beko mentoe.

355 Tang paissan lako kapa', mabeko lako unuran.

356 Tali to Batu naunu', seleng namangkai bongi.

357 La napandan anna sugi', naanna anna lellua, anna ma'kasea-sea.

343 'Hun staarten nemen de aanwijzingen goed in zich op", nl. van de bestuurder van de ploeg of de eg.

348 Aa': "helling", is een willekeurig gekozen naam.

349 Patundu' is eveneens een willekeurig gekozen naam.

350 to dipalempe dapo'na, 1tl. zij wier haardstede scheef getrokken werd. De slavenfamilie, die het te kwaad had bij Patundu' en bij hem werd weggejaagd, wilde graag dienst nemen bij de to barani, de held, tot wien de lofprijzing gericht wordt, omdat deze zo welvarend is. 
343 Aan hun voorzijde schoffelen hun horens, hun staarten nemen de aanwijzingen goed in zich op.

344 Wanneer er een harde kluit aarde is, bukken zij zich, dan blijft hun hoef er in steken.

345 Hun kin stoot ze geheel weg, dan is hun sawah vlak geworden als een vloer van planken.

346 Heel omlaag strekt de schrale grond zich uit, omhoog rijzen zijn velden met rijst beplant.

347 Wie zou zijns gelijke zijn, hem in verhevenheid evenaren?

348 Ik kom nu dan nog tot de horigen, de horigen aan de overzijde van ginds aan de Helling.

349 Het trof, dat Patundu' boos was, hij gaf zijn slaaf klappen om de oren.

$350 \mathrm{Zij}$, die uit hun haardstede gestoten werden, vertrokken met $z^{\prime} n$ allen van daar.

351 Gaan jullie regelrecht zuidwaarts naar het vertrek in het zuiden, dat is de slaapkamer in het Zuiden.

352 Hun werd siri-pinang aangeboden, zij weigerden, hun werd tabak gegeven, zij knikten van neen.

$353 \mathrm{zij}$ kwamen zich toch weer in slavernij begeven, hun werden de fijn gebroken korsten van de aangebrande rijst voorgezet.

354 Hun werden de losgemaakte stukjes kleefrijst voorgezet, zij zijn alleen onhandig bij het werken.

$355 \mathrm{Hij}$ is onwetend ten opzichte van de katoen, hij is onbeholpen ten opzichte van het spinnewiel.

$356 \mathrm{Hij}$ spint de hoofddoek van de lieden van Batu, een seleng-doek werkt hij in de nacht af.

$357 \mathrm{Hij} \mathrm{zal} \mathrm{het} \mathrm{bewaren,} \mathrm{opdat} \mathrm{hij} \mathrm{rijk} \mathrm{worde,}$ hij zal het opbergen, opdat hij welvarend worde, hij vermaard worde in rijkdom.

$351 v$. De bedoeling van deze twee strofen is, dat $z i j$ voor de schijn eerst als gasten werden ontvangen, maar dat afwezen en als slaven in dienst wilden genomen worden.

356 tali to Batu, 1tl. "hoofddoek van de lieden van Batu", is de benaming van een bepaalde maa': een oud tjindai-weefsel. 
358 Ma'dalle-dalle lompona, anakna ma'rere'-rere', indo'na ma'porrok pattung.

359 Anna iato muane, umpassan misa buangin.

360 Malolo tampo naola, sangluba'ba pamisakna, ditutung sangpealloan.

361 Anna la denda susinna la sipalinpa daona?

362 Langngan-langnganoi tau, pembulean pole'oi.

363 Langngan-1angnganmoko, gandang, pembuleanko, bombongan!

364 Langngan-langnganmoko, datu, pembuleanko, karaeng:

365 Langngan-langnganmoko, lalong, pembuleanko, buaja!

366 Langngan-1angnganmoko, indo', pembuleanko, pangria!

367 Langngan-langnganmoko, tumbang, pembuleanko, banaa!

368 Langngan-langnganmoko, rara', pembuleanko, bulaan!

369 Langngan-langnganmoko, londong, pembuleanko, muane!

370 Langngan-1angnganmoko, pasang, pembuleanko, pangkambi'!

371 Langngan-langnganmoko, pia, pembuleanko, baitti'!

358 ma'dalze-daZle, 1t1. ziet er uit als maîskorrels aan de kolf. De uitdrukking "heeft een ingedrukt zitvlak" wijst op corpulentie. Een bamboe drinkbeker is aan de benedenzijde niet vlak, maar wat hol ingedrukt.

366 indo' staat hier waarschijnlijk voor indo' bua': leider van de adatgemeenschap.

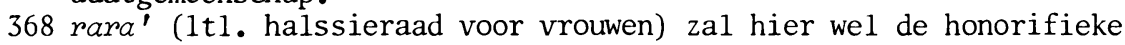
betiteling zijn van een vrouw van aanzienlijke stand, evenals bulaan in de volgende regel van een man van edelen huize. 
358 Zijn corpulentie heeft een huid, die korrelig is, de huid van zijn kinderen kan men indrukken, hum moeder heeft een ingedrukt zitvlak als van een bamboe drinkbeker.

359 En de man toch, hij draagt een casuarine-stam over zijn schouder.

$360 \mathrm{Hij}$ gaat over een rechte sawah-dijk, over het hele erf liggen de spaanders er van, zij worden gedurende de gehele droge tijd gebrand.

361 Is er iemand, die zijns gelijke is, die hem evenaart in verhevenheid?

362 Wanneer er ook lieden steeds maar omhoog stijgen, dan overtreft hij hen steeds maar.

363 Stijg gij maar steeds omhoog, to minaa, overtref gij hen, voorganger bij de offers!

364 Stijg gij maar steeds omhoog, vorst, overtref gij hen, prins!

365 Stijg gij maar steeds omhoog, held, overtref gij hen, vervaarlijke!

366 Stijg gij maar steeds omhoog, adathoofd, overtref gij hen, beschermer!

367 Stijg gij maar steeds omhoog, in taboe verkerende (op het Za'pa' kasaZle-feest), wees gij maar overtreffend, vat met rijst op het $l^{\prime}{ }^{\prime} p a^{\prime}$ kasazle-feest!

368 Stijg gij maar steeds omhoog, edele vrouwen, ga gij maar het andere te boven, man van aanzienlijke stand:

369 Stijg gij maar steeds omhoog, flinke kerel, ga gij de anderen te boven, heldhaftige man:

370 Stijg gij maar steeds omhoog, kudde dieren, ga de anderen te boven, gehoede buffels!

371 Stijg gij maar steeds omhoog, kind, ga gij de anderen te boven, kleine! 
372 La nalambi'oko tau, pembulean poleoko!

373 Alako tonglona sugi', kalandona kalaunan!

374 Langgi-langgina masua', turruk bakkun balusunna.

375 La'tek kulu-kulu langi', dao unuran bulaan, dao tingke' rau-rau.

376 La naunu' anna sugi', nae'te' anna lellua.

377 Anna ma'kasea-sea, anna tang disirantean, turruk bakkun balusunna. 378 La'tek kulu-kulu langi', la'tek kulu-kulu langi'.

373 kalaunan = kalajunan : heel hoge welstand, het schatrijk zijn. 
372 Degenen, die telkens tot u zullen reiken, ga gij op uw beurt hen weer te boven!

373 Bereik het toppunt van rijkdom, het hoogtepunt van welstand:

$374 \mathrm{Zijn}$ hoogheid is zeer machtig, zijn armbanden van schelp zijn talrijk.

375 Het gejubel van de bovenwereld klinkt luid op, het gouden spinnewiel daarboven, het spinrokken van gemengd goud daarboven.

376 Dat hij er op spinne, opdat hij rijk worde, dat hij het uitspanne, opdat hij gegoed $z i j$.

377 Opdat hij wijd en zijd vermaard $z i j$, opdat er geen zijn, die op hetzelfde niveau verkeren, zijn armbanden van schelp talrijk zijn.

378 Het gejubel van de bovenwereld klinkt op, het gejubel van de bovenwereld klinkt op. 


\section{Inleiding}

In deze "Lofprijzing op de slaven en de kinderen", evenals H III meegedeeld door $\mathrm{Ne}^{\prime}$ Todinglele in To'jasa (Tikala), wordt allerecrst gehandeld over kinderen die in bovenaardse toestand zullen geraken, zodat zij zich zullen richten tot hun grootmoeder, opdat dic met hen zal zijn en hetgeen aan het voorgeslacht was tocbetrouwd aan hen zal aanreiken (str. 12-18) .

In de loop van de singgi' worden woorden gewijd aan de welvaart van degenen, dic het feest hebben aangericht, de overvloedige oogst, te danken aan het zweet der slaven, dat rijkelijk is uitgevloeid. De oogst aan rijst was zo rijkelijk, dat de bossen moeilijk te dragen waren, het torsen er van veel inspanning gekost heeft (str. 50-58).

Degene, die de singgi' reciteert wil dan de gemeenschap reinigen, ondeugdelijke woorden wegvagen, ongunstige dromen wegwerpen, alle soorten van ziekten van mens en dier en gewas Zuidwaarts (de richting naar de dodenwereld toe) wegvagen (str. 67-77).

Vervolgens worden heilwensen uitgesproken en zegen en geluk aangeroepen te komen, het geluk van het uiterste einde van het land, het geluk dat woont aan de oorsprong van de rivier, het geluk dat voorspoed op de vlakke hand draagt en op het hoofd torst (str. 83-88). Mogen de zegeningen in een rij komen, en zich in omvang ophopen; mogen ze komen tot de leden van de gemeenschap en allen tot welzijn strekken; moge kinderzegen ons deel zijn en de kinderen zich voorspoedig ontwikkelen (str. 89-95).

Daarna gaat de lofprijzing over op de voorvaderen der kinderen, wier geboorte op miraculeuse wijze heeft plaats gehad, in de bewoordingen, die we ook in H III aantreffen (str. 96-105). Bij het opgroeien werden zij gekoesterd door de adatvoorschriften en adatverrichtingen (str. 106v.). Er is een overvloed van water in hun bron, buffels zijn 
In de laatste strofen (127-130) wordt ten opzichte van de slaven de wens geuit, dat zij ijverig mogen zijn in hun werk en als de buffels, die voor de ploeg worden gespannen bij het bewerken der rijstvelden, dienst mogen doen en dat zij hun heren mogen volgen, wanneer die gaan huwen en Oostwaarts of Westwaarts, Zuidwaarts of Noordwaarts gaan trekken. 
Tekst

\section{Sesse rora'!}

1 Tipaladikko dena'na, rombe ulang bulaanna.

2 Sarapang makaiananna, disuloan malapu'na.

3 Malapa' anna pare, matarerreng na kinande.

4 Iko angga to mengkita, mairi to sae allo,

5 angga to ratu nasiang, nakuanna' to mengkita:

6 "Minda to limbo to tumbang?" La naissandaka to le!

7 La nakatonganandika, la nakaluteiraka?

8 Kada tongan toda to, la kuissandaka to le, la kukaluteiraka?

9 Bela, perangiina' mati', ammi tanding talingana':

10 Palangngan-1angnganni sarong, toke' toangi kambuno!

11 Karerungan manii gandang, anna tang makaananmo.

12 Baitti'pa angku tumbang, piapa' angku malangi'.

13 Nakuanna' to nene'ku, to tau panglalanangku:

14 "Iake lemboko tumbang, ke la rorakko malangi',

15 pokadanna' anta sola, angku butung dio ren.

2 "hun grote gouden hoogwaardige kris" is de honorifieke betiteling van de aanzienlijke man, die het bua'-feest heeft aangericht.

3 kinande, een zeldzame vorm met het invoegsel -in-, 1t1. hetgeen gegeten wordt; het is de parallel van pare: rijst.

11 gandang, $1 t 1$. trom; in d.t. de benaming van een to minaa. 


\section{Vertaling}

Her en der luid opklinkend:

1 Laten hun rijstdiefjes het vlug doen, de franje van hun gouden koord.

2 Hun grote gouden hoogwaardige kris, laat uitgezocht worden voor hen hetgeen inhoudrijk is.

3 Inhoudrijker dan rijst, voller van inhoud dan het dagelijks voedsel.

4 Gij gehele menigte, die komt toeschouwen, gij allen, die overdag gekomen zijt,

5 allen, die in de morgenstond verschenen zijt, $\mathrm{zij}$ die toeschouwen zeggen tot mij:

6 "Wie zijn zij, de groep van in bovenaardse tocstand verkerenden?" Zou men het weten, zeg eens:

7 Zou men er echt van op de hoogte zijn, zou men het vlot weten?

8 Het is voorzeker een waar woord, zou ik het weten, zeg eens, zou ik het vlot weten?

9 Vriend, luister naar mij, neig uw oor tot mij!

$10 \mathrm{Til}$ de zonnehoed goed op, hang het zonnescherm van bladeren van de waaierpalm op, wat van je af.

11 De to minaa mocht eens onttrokken zijn aan het gezicht, zodat hij niet meer te zien is.

12 Toen ik nog klein was, was ik in bovenaardse toestand, toen ik nog een kind was, was ik in vervoering.

13 Toen zeide mijn grootmoeder tot mij, mijn leidsvrouwe:

14 "Indien gij in een groep van in bovenaardse toestand zijnden zijt, wanneer gij in menigte verbreid in vervoering zijt,

15 zeg het mij, opdat wij het te zamen zijn, opdat ik als het ware er bij ben.

14 Zembo (niet vermeld in Wb.) kan een nevenvorm van Zimbo (str. 6) zijn. (Red.) 
16 Untadoiko pantoto, umbenko tang sada-sada."

17 Mangilalanna nene'ku, paissanna to doloku.

18 Mangilala lao' Teang, paissan lao' Lakaang:

19 'Tia' langkanko mai, sajang kaluppini'ko.

20 Ta'pa daoko tandukku, dao randan sule lengku.

21 Paleppeng patomalingku, lan sumbang barokoku.

22 Dio randanna pudukku, puduk ma'neko-nekoku.

23 Laan tilengkona ta'dung, tiguririkna kambuno.

24 Kunii untolo' nani, umpana'ta' karombian."

25 Daana' ulunna salu, tiparitikna uai, tiembonna bura-bura.

26. Nakuanna' to mangkambi ', sola to manglaa tedong.

27 To massumba' lao' mai, to ma'boron-boronanni, millikna' marungu-rungu.

28 Ba'pan tanduk kuangkaran, bangkula' lan di limangku.

29 Nadende-dendean datu, nasoenan ampu lembang.

30 Nakangkan rangga inaa, rangga inaa disondong.

16 pantoto $=$ panoto: juist, het doe 1 rakend .

18 Lakaang zou misschien Lakadjang in Djeneponto kunnen zijn.

20 randan suleleng, 1tl. rand van het rotan hoofddeksel, versierd met platte, geelkoperen horens.

21 paleppeng, elders palempeng: schouder. sumbang barokoku, 1t1. op de grens van mijn hals.

24 umpana'ta', 1tl. met een liniaal de scheringdraden uiteenhouden bij het weven. 
16 Ik reik je het juiste toe, ik geef je hetgeen niet verkeerd is."

17 De vermaning van mijn grootmoeder, de raadgeving van mijn voorgeslacht.

$18 \mathrm{Zij}$ vermaande mij in het Zuiden in Teang, $z i j$ gaf mij raad in het Zuiden in Lakaang:

19 "Vlieg als een kiekendief hierheen, zweef als een zwaluw.

20 Zet $u$ neer boven op mijn horen, boven op de rand van het gedeelte van mijn hoofd, dat met een hoofddeksel bedekt is.

21 Op mijn beide schouders, tussen mijn hals en schouder.

22 op de rand van mijn lippen, mijn druk babbelende lippen.

23 In de vouw van het zonnescherm, in de wenteling van het scherm van de bladeren van de waaierpalm.

24 Daar rijg ik de lofprijzingen aaneen, uit ik in volgorde de lofdichten."

$25 \mathrm{I} k$ ben in het Noorden aan de oorsprong van de rivier, aan de vloeiing van het water, waar het schuim opgolft.

26 De buffelhoeders zeggen het mij, en $z i j$, die de karbouwen weiden.

27 Degenen, die uitnodigen, komend uit het Zuiden, die op royale wijze geschenken brengen, ik sta nog slaperig op.

28 In de vuist houdend de horens, dic ik opzet, de koperen bel is in mijn hand.

29 De heren schudden ze, de machthebbers in de adatgemeenschap zwaaien ze. 30 De lieden, die helder van geest zijn, houden ze in de palm van de hand, de lieden, die helder van geest zijn, zijn in het vertrek.

$28 \mathrm{Bij}$ de manganda'-dans op het la'pa' kasalle-feest zijn de mannen getooid met buffelhorens, die met oude doeken omwikkeld en met oude munten bezet zijn. 
31 Banne ba'tang dianginni, soda' ri tangnga banua.

32 Kulaoan ri sondongku, kuke'deran banuangku.

33 Angku tumengka i ampang, angku tumengka i tangdo'.

34 Angku merrassai litak, unnola pangalloan pare.

35 Anna randan pamisakan, sulluk ri rombe ao'na.

36 Kulaoan ri bambaku, kuke'deran sulunangku.

37 Unnola buntu tang damma', tanete tang beluakan, lombok tang rato-ratoan.

38 Umpemaelo manukna, umpesampa' garentena.

39 Giling-giling dipadolo, lale ummatai lalan, tinti kanan kairinna.

40 Kao malang dio mai, langkan lumisu lu langngan.

41 Angku lamban diong salu, angku mentete uai.

42 Salu unnondo batunna, salu tumbang karanganna.

43 Urrundu' lengkona salu, unnola tampo malolo.

44 Kadajang tang silambanan, kalo' tang siperapian.

45 La randukmo mempangala', unnola kakauanna.

46 Tallu uase kupu'pu', a'pa' bingkung kubaenan.

36 suZunan, 1t1. opening in de omheining van het dorp.

37 tang domma', $1 \mathrm{tl}$. ook niet een weinig gebarsten. tang beluakan, 1tl. zonder enig barstje.

38 garente, $1 \mathrm{tl}$. trillend geluid (hier van een vogel), dat als voorteken beschouwd wordt. 
31 Het kroost der scherpzinnigen daar waait de wind overheen, de lieden van goede manieren zijn in het midden van het huis.

32 Zodat ik uit mijn vertrek ga, ik uit mijn huis vertrek.

33 Dan betreed ik de drempel, dan betreed ik de voorgalerij.

34 En ik stamp op de grond, gaande over de droogplaats van de rijst.

35 in de rand van het erf, waar het hout gekloofd wordt, onder de schaduw van de neerhangende franjes er van.

36 Ik ga uit mijn nederzetting, ik vertrek uit mijn dorp.

37 Betredende de berg zonder leed, het gebergte zonder tegenspoed, het dal in het geheel niet door ongeluk getroffen.

38 lict goede voortcken er voor zoekend, het beste geluidsteken or voor afwachtend.

39) Het belletje laat men vooruitgaan, luid gelach is gids op de weg, en kwinkelerend geluid is er links en rechts.

40) De grauwe reiger neigt er vandaan, de kiekendief vliegt in kringbewegingen omhoog.

41 En dan steek ik de rivier over, en loop over het water.

42 Een rivier welks stenen hossen, welks kiezel danst.

43 De bochten van de rivier volgend, langs de rechte dijk lopend.

44 Langs een vak bewerkte grond, dat recht toeloopt, greppels, die niet in elkaar lopen.

45 Ik zal gaan beginnen in het bos te lopen, ik trek door het geboomte.

46 Drie bijlen verslijt ik, vier dissels (maak ik stomp) bij het werken er mee.

$40 \mathrm{kao}$ is de vorm, die in de N.W. districten in gebruik is voor kajo (grauwe reiger); evenzo in str. 45 kakauan voor kakajuan.

44 tang silambanan, 1tl. niet tot elkaar overgaande ( $W b ., 263 b)$. siperapian, 1tl. elkaar om iets vragen zonder iets terug te geven; vgl. ook str. $122+$ noot. 
47 Kubotta'-bottaran lalan, nalempe-lempei baan, natiro dassi londongna.

48 Dolo daona' Sesean, tiumba' kapadanganna.

49 Kumangnga-mangngai aku, pussakna' umpenaanni.

50 Gandang bua' te kurangi, talinting tumbarakana.

51 Ul lambi 'mo' to mangkambi', sola to manglaa tedong.

52 Angku lendu' inde diong, umpemamun to mengkita, unnellak to kaiangan.

53 Apa to indemo' pole, ussuloi tannunangku, untinti pa'kalarangku.

54 Nakuanna' to mengkita, angganna to sac allo, angga to ratu masiang,

55 nakuanna' dio mai, kada napatuleranna':

56 "Tibaku-baku ma'pu'mu, tisea' lite lindomu."

57 Kukuannami lako, randan pudukku kumua, talinting lengko lilaku:

58 'Magasana' umbaa pare, sipamellen pare lapu'."

59 Iko angga to mengkita, matangkingko maea'ko, torro tang lenda-lendako.

60 Patarimako baumiu, balla'ko lindo piomu.

52 to kaiangan = to kajangan: 1ieden door een geest bezeten, vgl. Indon. jang: goden, kajangan: godenverblijf.

53 untinti pa'kalarangku, 1t1. opheffend mijn draden, die de scheringdraden om en om uiteenhouden bij het weven.

56 lite, 1tl. plantesap, plantegom.

59 maea'ko, elders: maia'ko: reken nauwkeurig. 
47 Ik hak er het struikgewas op de weg mee om, de parkieten kijken er met een scheef kopje naar, het mannetje van het honingzuigertje bekijkt het.

48 Eerst ben ik boven op de Sesean, plotseling worden de landstreken zichtbaar.

49 Ik ben er verbaasd over, ik ben verbijsterd het in mijn geest opnemend.

50 De trom van het bua'-feest hoor ik, het gerinkel cn het slaan op de trom van het offerfeest.

51 Ik kom aan bij de buffelhoeders, en de karbouwenherders.

52 Dan kom ik hier voorbij, het gegons horend van de toeschouwers, tussen de vrouwen, die door een geest bezeten zijn, in lopend.

53 Maar ik ben toch weer iemand van hier, hetgeen ik verzorg beschijnend, de taak, aan welke ik begonnen ben, weer opnemend.

54 De toeschouwers zeggen tot mij, allen, die overdag zijn gekomen, allen, die bij daglicht verschenen zijn,

$55 \mathrm{zij}$ zeggen daar tot $\mathrm{mij}$, $z i j$ brengen mij de woorden over:

56 "Uw zweet is rijkelijk uitgevloeid, het vocht van uw gelaat is uitgestort."

57 Ik zeide tot hen, uit de rand van mijn lippen kwamen de woorden, het klingelend geluid van mijn woorden in geregelde volgorde gesproken was:

58 "Ik kan de rijst moeilijk dragen, de rijst met een gevulde korrel vereist bij het torsen veel inspanning."

59 Alle gij toeschouwers, let goed op, rekent nauwkeurig, blijft zonder vergissing.

60 Ontvangt ze in uw baadje, slaat de voorzijde van uw lendengordel open. 
61 La umpa'duana' pare, la mpa'talluna' kinande, kutaan to mengkita,

62 kupalulako sandoku, kupalutama sepu'ku.

63 Manokana' duka la sau', rampanmi sanglajanganna.

64 Sangpuntaran bulajanna, sangduro banne manikna.

65 Kediborong-boronganni, ke dilaang-laanganni,

66) la kukuari pole'na, la tendi pa'kadanangku:

67 'La massarapamo' inde, ussarrinni kada bengnga',

68 unt ibe tindo kadake, saki ulu, saki mata.

69 Saki rumende di posi', saki tindak ri bannean.

70 Sakinna rampanan kapa', sakinna mellolo tau.

71 Kusarrinni kubaai, kuramba mambela-bela.

72 Sakinna kurrean manuk, sakinna doko maripi'.

73 Sakinna asu ranganan, sakinna ma'bala tedong.

74 Sakinna tallu lolona, saki a'pa' tauninna.

75 Kusarrinni kubaai, kuramba mambela-bela.

76 Kupamalengko lalanna, kuparundu' salu sau'.

64 banne manik, 1tl. het zaad, glanzend als kralen.

67 bengnga', 1t 1 . splinter, spaander.

74 tallu Zolona, 1t1. hun drie navelstrengen, nl. van mensen, rijst en buffels; a'pa' tauninna, 1tl. hun vier nageboorten, hier de parallel van tallu lolona, waarmee eveneens mensen, rijst en buffels worden aangeduid. 
61 Opdat ik de rijst in tweeën dele, het voedsel in drieën verdele, ze uitdele onder de toeschouwers,

62 ze aan mijn vrienden doe toekomen, ze in mijn sirihtas doe.

63 Ik wil niet dat ze Zuidwaarts ga, een deel er van is weggegaan.

64 Een gouden kring er van, een rij van het zaad, glanzend als kralen.

65 Wanneer het in delen verdeeld wordt, wanneer het in porties geordend wordt, 66 dan zeg ik toch, dan zou zó mijn wijze van spreken zijn:

67 "Ik zal hier gaan reinigen, ik zal ondeugdelijke woorden wegvagen,

68 ongunstige dromen wegwerpen, hoofdpijn, oogziekte.

69 Ziekte van kloppen in de navel, ziekte van koliek uit de onderbuik.

70 Iets, dat onheil brengt over het huwelijk, ziekte bij het geboren worden van een mens.

71 Ik vaag ze weg, ik voer ze weg, ik drijf ze ver weg.

72 Ziekte bij het houden van kippen, ziekte van de kort na elkaar jongende zeug.

73 Ziekte van de jachthonden, ziekte bij het houden van buffels.

74 Ziekte, die het gedijen van mensen, rijst en buffels aantast, de ziekte van het viertal vrucht dragenden.

75 Ik vaag ze weg, ik voer ze weg, ik drijf ze ver weg.

76 Ik zal hun weg doen kronkelen, ik zal ze de rivier Zuidwaarts doen volgen.

76 "de rivier Zuidwaarts doen volgen", d.w.z.: voeren naar het gebied van de rambu solo": "de neerdalende rook", d.w.z. het gebied der doden, het gebied van de doodsfeer. 
77 Kupalamban lian Daa, sambalin to' sarang-sarang."

78 Tau apapara lan?

pada pesese isinna, pada bingkung talinganna.

79 Ia umpakamangkai, umpakare'na-re'nai.

80 Tae'mo pandiu sule, tae'mo pakini-kini.

81 Dibala buntunna lako, dikatonan tanetei, dirompo batu bangkula'.

82 Rampanomi sanglaanganna, sangpuntaran bulaanna, sangduro banne manikna.

83 La kukuari pale'na, kukadangampoko tua'.

84 Tang tua'na sangtondokta, tang paraa sangbanuanta.

85 Tua'namo bala lembang, paraa rompo minanga.

86 Tua' matallo matampu', tua' te ingkokna padang.

87 Tua' te mennulu salu, tua' parande padudung.

88 Tua' te tangngana langi', tua' matallo matampu'.

89 Tua' pa'lengkoko mai, paraja pa'tinangguko.

90 Kupalulako sandoku, poparaako tua' sanda.

77 "naar de overzijde naar Java" zal wel de betekenis hebben van: naar het gebied buiten het eigen door de adatinzettingen beschermde land. sarang-sarang: een plant met ronde, vingervormige bladeren, die op heuvels groeit.

78 pesese: schopje met korte steel om gras af te steken, of te wieden.

83 kukadangampoko tua', 1tl. ik zal geluk voor u afhaken.

86 ingkokna, 1tl. de staart er van. 
77 Ik zal ze naar de overzijde naar Java doen oversteken, aan de overzijde van de plaats van de sarang-sarang-planten."

78 wat zijn dat voor mensen daar?

hun tanden zijn als schoffels, hun oren als dissels.

$79 \mathrm{Zij}$ brengen ze tot een einde, en vermanen hen.

$80 \mathrm{Zij}$ worden niet meer wakker, er is geen flikkerende beweging meer in.

81 De weg er heen is omheind met bergen, hij is begrensd door gebergten, omrasterd door rinkelende gesteenten.

82 Een deel er van is weer weggegaan, een gouden kring er van, een rij van het zaad, glanzend als kralen.

$83 \mathrm{Ik}$ zal het dan toch zeggen, ik zal geluk voor $u$ afsmeken.

84 Niet het geluk van dorpsgenoten, niet het heil van onze buurtgenoten.

85 Het geluk van het gebied door het landschap omgeven, de omheining van de monding van de rivier.

86 Het geluk van het Oosten en van het Westen, dit geluk van het uiterste einde van het land.

87 Dit geluk, dat woont aan de oorsprong van de rivier, het geluk, dat op de vlakke hand draagt en op het hoofd torst.

88 Dit geluk van het midden van het uitspansel, het geluk van het Oosten en van het Westen.

89 Geluk, kom in een rij hierheen gelopen, voorspoed, hoop $u$ in omvang op.

$90 \mathrm{Ik}$ doe het tot mijn vrienden komen, laat een volkomen geluk $u$ tot heil strekken.

87b Vg1. puang parande padudung, 1tl. heer, die op de vlakke hand houdt en op het hoofd draagt, in d.t.: heer, die behoedt en verzorgt ( $\mathrm{Wb} ., 499 \mathrm{a})$.

89 pa'tinanggu: zich laten ophopen; afgeleid van tanggu: vasthouden, opdat het zich vermeerdere.

90 poparaako tua' sanda, 1 tl. neemt een volkomen geluk tot heil. 
91 Paraa sampe mairi', pokabanko tuo-tuo.

92 Anta masakke sisinggi', marudinding silolloran.

93 Mol imbo-l imbomo pia, mokurunganmo baitti'.

94 Kumombongmo tang unnissan, la dikarombian pia, la unnassa pia.

95 Karombian busarungngu', ba'baran bupare kombong, tungka buambaang tasak.

90 la kulambimo dadimmu, kudete'mo garagammu.

97 Tang ambaang, tang dadeko, tang pao, tang ilu-ilu.

98 Bulaan pangidenanna, rara' clo'-cloranna.

99 Dikauan tallu manuk, dialan atena langi'.

100 To diparede bumbungan, to dikombong pare puru'.

101 Barra' dirangga-dirangga, barra' ditanda lallodo.

102 Bo'bo' didatui manna, dikande untampa pia.

103 Urrende-rende baitti', ungkombong tang unnissan.

104 Iami ditambuk bua, diselle' kalapa matasak.

105 Anna marumbo dadinna, anna 1obo' garaganna.

91 pokabanko, 1tl. moogt gij u hullen in een lappendeken.

92 masakke en marudinding, 1tl. koel.

93 mokurungan: bijeen zitten in een kring, rond als een kurungan: een visvijver; mokumungan is een der in het Sa'dan Toradjaas zeldzame mo-vormen.

95 busamingngu': geurig. pare kombong: harige, witte kleefrijst, die geurig is. combaang, zie op H III, 28. 
91 Mogen allen voorspoedig en gezegend zijn, moogt gij $u$ hullen in welzijn als in een kleed.

92 Mogen wij in welvaren elkander prijzen, in voorspoed elkaar loven.

93 Mogen de kinderen talrijk bijeen zijn, de kleinen in een kring bijeen zitten.

94 Mogen de nog geen weet hebbenden zich ontwikkelen, opdat de kinderen geloofd worden, om de kinderen flink toe te spreken.

95 Moge de lofprijzing welaangenaam zijn, de flinke toespraak de geur hebben van klecfrijst, echt de geur hebben van de grote mangga.

96 Laat ik tot uw geboorte komen, tot uw ontstaan geraken.

97 Geen grote mangga, geen mangga, geen andere manggasoort, geen vrucht, wrang van smaak.

98 Maar naar goud gingen haar zwangerschapslusten uit, naar een gouden halssieraad haar begeren.

99 Er werd een kippeëi gestoten voor haar, de lever van het uitspansel werd voor haar gehald.

$100 \mathrm{Zij}$ waren lieden op grootse wijze voortgebracht, lieden ter wereld gebracht als kleefrijst.

$101 \mathrm{Als}$ ontbolsterde rijst in verschillende kleuren toebereid, ontbolsterde rijst gekenmerkt met het donkere sap van de Zazlodo-plant.

102 Als slechts op exquise wijze gekookte rijst, gegeten bij het ter wereld brengen van een kind.

$103 \mathrm{Zij}$ baarde de kleinen,

zij bracht nog onwetenden ter wereld.

$104 \mathrm{Zij}$ werden in de baarmoeder gedragen zoals een areca-vrucht in de schoot gedragen wordt, zij droeg hen in het lichaam, zoals een rijpe areca-vrucht in de schoot gedragen wordt.

105 En zo ging hun geboorte voorspoedig, en was hun volwassen worden goed gedijend.

100 to diparede bumbungan zie H III, 31.

101 laZlodo: kruipplant, waarvan de bladeren als groente gebruikt worden; de rijpe vruchten zijn donker gekleurd en bevatten een donker gekleurd vocht. 
106 Kasalle naria aluk, lobo' nasambe bisara.

107 Kasalle naria suru', lobo' nasambe sara'ka', naria pengkalossoran.

108 Anna balida tibongso', anna tannun kaloloan, sipakaboro' sakke malino.

109 Titampan pekali bassi, dipantananni lolona.

110 Dipada' rambo-rambona, rokko ditambuli padang.

111 Tuo timun diong mai, ia massonggo malea.

112 Dadi sarita lolona, kombong maa' tauninna.

113 La napandan anna sugi' , la naanna nalellua, anna ma'kasea-sca.

114 Kasalle naria aluk, lobo' nasambe bisara, naria pengkalossoran.

115 Kasalle naria suru', lobo' nasambe sara'ka'.

116 Iami turusan bubun, pada kasalle bubunna.

117 Pada lobo' turunanna, anna marumbo dadinna, anna 1obo' garaganna.

118 Turiangna gaang bubun, sarapang sakke malino.

106 naria, 1t1. zij werden op de schoot gehouden. nascombe, 1t1. zij werden ombonden met een touw, tegengehouden, zodat zij niet konden vallen.

108 De regels a en b geven te kennen, dat zij op vlotte wijze ter wereld kwamen; regel c wil zeggen, dat zij met helder water gebaad werden.

116 Iami turusan bubun, 1t1. zij hadden, die achter hen aanliep naar de bron; pada kasalle bubunna, 1t1. even groot als hun bron. 
106 Groot wordend werden $\mathrm{zij}$ door de adatverrichtingen gekoesterd, zij gedijden beschermd door de adatvoorschriften.

107 Groot wordend werden zij gekoesterd door de reinigingsoffers, zij gedijden beschermd door de uitdelgingsoffers, zij werden gekoesterd door de zoenoffers.

108 Zodat zij waren als een neergeschoven weeflat, en een vlot geweven weefsel, zij en het heldere water hielden van elkaar.

109 Er was een ijzeren graafstok voor hen gesmeed, daarmee werd hun navelstreng begraven.

110 Hun nageboorte werd begraven in aarde, die stevig werd vastgedrukt, ze werd beneden in de grond gelegd.

111 Er groeide komkommer uit op, die heeft rode pluimen.

112 Hun navelstreng was cen sarita-dock, hun nageboorte had de vorm van een maa'-weefsel.

113 Men ging ze neerleggen, opdat zij rijk zouden worden, men ging ze optergen, opdat het hun wel zou gaan, opdat zij zouden uitdijen.

114 Groot wordend werden zij door de adatverrichtingen gekoesterd, zij gedijden beschermd door de adatvoorschriften, zij werden gekoesterd door de zoenoffers.

115 Groot wordend werden zij door de reinigingsoffers gekoesterd, zij gedijden beschermd door de uitdelgingsoffers.

$116 \mathrm{Zij}$ konden al naar de bron lopen, zij groeiden goed op evenals hun bron, waarin het water steeds toenam.

117 Het ging hun even goed als hun put, en het ging hun voorspoedig, hun volwassen worden was goed gedijend.

118 Hun put had de schittering van een gouden kris, het heldere water was als een grote gouden $\mathrm{kr}$ is. 
119 Pada kasalle bubunna, pada lobo' turunanna.

120 Napengguririkki ianan, napengguririkki tedong, napengguririkki ringgi'.

121 Ke diborong-boronganni, ke dilaang-laanganni, ke pantan patu i lako,

122 manoka ia silambanan, kalo' tang siperapian.

123 La kukua pole'omi, turiangna tangdan langi' .

124 Tiku tambingna batara, turiangna tangdan tasik.

125. Tiku tambingna minanga, turiangna tanglan issong, tiku tambingna ta'pian.

126 Anna matrumbo dadinna, anna loho' garaganna.

127 Nna matutu disua, dipotedong-tedong uma, dipokarambau tempe'.

128 Male ma' ramanan kapa', lako matallo matampu'.

129 To sau' engkokna padang, to rekke mennulu salu, to laan tangngana padang.

130 Male unnula' puangna, anna matuttu' nasua, anna matuttu' nasua.

122 kalo' tang siperapian, ltl. (zijnde als) greppels, die elkaar niets hadden te vragen, ieder voor zich voldoende water hadden; voor silambanan en siperapian zie ook str. $44+$ noot. 
$119 \mathrm{Zij}$ werden even groot als hun put, zij gedijden gelijk op met hun bron.

120 De bezittingen omringden hen, hun buffels liepen om hen heen, zij werden omringd door rijksdaalders.

121 Wanneer ze in delen zouden worden afgescheiden, wanneer ze verdeeld zouden worden, wanneer elk naar zijn bestemming zou gaan,

122 dan wilden zij niet, dat zij van de een naar de ander zouden overgaan, zij wilden, dat ieder het zijne zou bezitten.

123 Laat ik wederom spreken over de schittering der vloerbalken van het uitspansel.

124 Het aangebouwd vertrek van de lucht rondom, de schittering der vloerbalken van de zee.

125 Het aangebouwd vertrek van de riviermonding rondom, de schittering der vloerbalken van het rijstblok, het aangebouwd vertrek van de bolsters rondom.

126 Opdat het hun wel zou gaan, en hun volwassen zijn goed zou gedijen.

127 Opdat zij ijverig zullen zijn bij hetgeen hun bevolen zal worden, zij als buffels van de sawah zullen gebezigd worden, als karbouwen van het rijstveld.

$128 \mathrm{Zij}$ zullen gaan huwen, naar het Oosten en naar het Westen.

129 Enigen Zuidwaarts naar het uiterste der aarde, enigen Noordwaarts naar de oorsprong van de rivier, anderen in het midden der landen.

$130 \mathrm{Zij}$ zullen hun heer volgen, mogen zij zeer ijverig zijn bij hetgeen hun bevolen wordt, mogen zij zeer ijverig zijn bij hetgeen hun bevolen wordt. 
H. van der Veen - 978-90-04-28716-7 Downloaded from Brill.come4/26/2023 02:54:12PM via free access 


\section{LIJST VAN ZUID-TORADJASE NAMEN, WOORDEN EN UITDRUKKINGEN DIE MEER DAN EEMMAAL IN DE TEKSTEN VOORKOMEN}

De woorden en uitdrukkingen zijn opgenomen in de vorm die zij in de teksten hebben. - De letters A, B, C, E (I-IV), F, G, H (I-IV) duiden de teksten aan, de Arabische cijfers verwijzen bij tekst A (= "Ossoran tempon daomai langi"", in BKI, 132, jg. 1976, 418-438) en tekst B naar de genummerde noten, bij de andere teksten naar de strofen waar de verklaring te vinden is, in tekst of/en noot, een enkele maal naar een blz. Soms bleek het echter beter de verklaring in de lijst zelf te geven.

ambaang, H III, 28. anak dara, E Ia, $197 \mathrm{v}$. aoka, H III, 342 . asik, F, 104.

Ba'baalang, E Ib, 73 . ba'baran, H III, 21. bai tora, E IV, 17. bajak, E Ia, 121.

bala kollong, G, 24. bala salzi', H III, 216. Bambalu: dorp in het landschap Piongan. bomburang $=$ amburang, $\mathrm{A}, 50$. banaa = banaja, E Ia, 23 en 277 . bangkudu, E Ia, 4.

Bangkudu, E III, 83.

bangkula', $\mathrm{H}$ II, opschrift. banne ba'tang, H I, 36; H III, 295.

banne manik, H IV, 64.

banno (= banu') karuming, C, 56. bao-bao = bajo-bajo, F, 23.

Barrangdilangi', A, 13 . Baruppu', E III, 61. barura, E Ia, 43.

bate (manurun), E IV, In1. en aant. op str. 1. battu = battuan: zinvol. Batu, B, 6 en E Ib, 62 . Batuapian, A, 105. batu batangna, A, 46. Batumaetan, E Ia, 190. Batupapan: plaats in het landschap Sangalla', dicht bij de tongkonan Kaero.

Batupiak, E Ib, 23. bau = baju, E IV, 12 . Belau, E III, 63. bendo', B, 27; E Ia, 50; E II, 3 . bengnga', H IV, 67.

betau, A, 66.

bete, H III, 190.

biang: pijlriet, een kleine rietsoort, Miscanthus Japonicus Andersen.

biladong sa'de banua, H III, 190. bola, E Ia, 177. bolo', E Ia, 188. bombongan to palullungan, (i, 2 . Bombouai, E Ib, 28. bongsu, C, 21. botikan, H III, 38. buaa = buaja, H III, 221, vgl. op E Ia, 50 .

Bualajuk, E Ib, 53.

Buatabang, A, 72. bugi' en bugiran, E Ia, 9. bulean = balian, F, 110 .

Bumbungan rante, $\mathrm{A}, 20$. burake tatti $(k) u^{\prime}, \mathrm{E} \mathrm{Ib}, 31$.

Buriko', A, 41.

Dai-Dai, E Ib, 62. damma', H IV, 37. dannari (Zambe'), H III, 183. datte', voor pare datte', H I, 33. Datu Laukku', A, 22. datu matasak, 1tl. "de Heer van zuiveren bloede", zie A, 59. Datu Merrante, A, 42 . demmeran para, H III, 205. diesse'i, H III, 215. diindan, H III, 40. dikitta', H III, 34. dikulea'i, H III, 74. diorongi, H III, 74. dipangidenan (ni), E Ia, 10; G, 5 . diparede bumbungan, H III, 31 . diruma-ruma, H III, 77. 
ditodingan, H I, 27.

doke deata, E Ia, 83.

doko maripi': de steeds jongende

zeug.

doti langi', E III, 7 .

$e$, E Ia, 66.

enda = eran, G, 21.

eran: trap; ma'pasilau' eran:

trapsgewijze op elkaar laten volgen.

Eranbatu, E Ib, 54; ook naam van een landstreek op de grens tussen de complexen Lolai en Salu.

gajang, $\mathrm{H} \mathrm{I}, 2$.

gandang, H IV, 11; in andere be-

tekenis, H II, 24.

gandang langi', $G, 2$.

Gauntikembong, A, 7 .

gora tongkon, H III, 66.

gorang, H, Alg. Inl.

ilampa-lampai, E Ia, 64.

indo', H III, 151 en 366.

Indo' Belotumbang, $\mathrm{E}$ Ia, 5.

Indo' Pare'-Pare', 1tl. 'Moeder

Kleine Rijstsoort", zie $A, 74$.

Indo' Samadenna, A, 12 en 74 .

induk, C, 56.

induk mekasiri'-siri', H III, 189.

ingkokna = engkokna, H IV, 86.

kabarre-alzoan, C, 33.

Kabongian, E Ib, 21.

kabusungan, A, 69.

Kaero, C, 29.

kaise', E Ia, 146.

kakojan balo, E II, 3 .

Kakondongan, E Ib, 25.

kalindo bulanan, C, 33.

kalosi dibuni, itl. areca-noten

die verborgen gehouden worden, voor: heimelijk sirih-pinang vragen aan elkaar; overdrachtelijk: ontucht plegen met elkaar.

kaluku, H II, 45.

kambu, H III, 103.

kambuno, C, 57.

kande limarmu, A, 111.

kanuku diarru', itl. wiens nagels

met een mesje geschrapt worden.

$k a o=k a j o, \mathrm{H} \mathrm{IV}, 40$.

kapa', B, 12.

kapoenanna $=$ kapueanna, F, 90.

kara kau = kara kaju, H III, 241.

karaeng, A, 26.

Karua: gebergte met acht toppen

in het landschap Bettuan.

kasao-sao $=k a s a j o-s a j o, F, 66$. kaso mentcomben, H III, 117, vgl. B, 25 .

katarananna, E IV, 22.

katimbang, F, 54 .

kemasak z. masak.

kendek marampa' langngan randanan:

steeg in welstand op naar de oever, vg1. ook A, 123.

kiding-kiding, H I, 77.

kimesongi-songimora $z$. songisongi.

kinande, $\mathrm{H}$ IV, 3.

kolzo-kolzo, E Ia, 217.

kotti', een speelse nevenvorm van kondi'.

kuli'na padang, A, 99.

kuli' piong, H III, 79.

Kumirrik, A, 36.

kumombo, F, 4.

kumukkiua, E Ia, 194.

kutengkai kalo', A, 107.

Labengnga', A, 39 .

Labiu-biu, naam van een der voorvaderen, vgl. A, 2 .

Zambanan, B, 19 en H II, 13.

Lambung, E III, 71.

Tompo', E IV, 14.

Landobeluak = Landorundun, B, 22 .

Ia'pa' dena', ltl. La'pa'-reest, klein als een rijstdiefje.

lapandek, H I, 12.

lassigi // tabang, E la, 27.

la'te mamara, E Ia, 143.

Lauran, getrapte volgorde.

Lebukan, A, 101.

lemba kalando, A, 54 en 134.

Lempo, E III, 55 .

lengko Zila, E Ia, 15.

Lepongbulan, E III, 40.

likaran biang: offer gebracht op een offerstelletje, gevormd door vier rietstengels.

Limbongallo, E Ib, 71.

Limbu: dorp in het Ma'kalese.

Lindotau, E Ia, 190.

lokkon, E Ia, 43, vgl. C, 14.

Lolai, F, 92.

Zondong, B, 23.

Lonno': struik met ovaalvormige

bladeren en witte bloesems.

Lua'kollong, A, 40.

Zua'toding, E Ia, 35.

Zumbaa langi', H III, 57.

Zumokkon la Zanna, C, 34.

maa': oude katoenen tjindaiweefsels.

ma'belo tadi: in goede staat zijn van de kunstsporen. 
Ma'buku bulaan, A, 37. ma'kekeran bassi, C, 1. makkundai, $\mathrm{F}, 21$.

ma'lando petorak, 1tl. hij gebruikte een lange schoffel. $m a^{\prime} l a(j) u k$ lamba', H III, 157. ma'lia-lia, F, 41 .

Mamullu, E Ib, 32 . manangnga, E Ia, 262. mandai', E Ia, 231. mandoti, H I, 33. mangaku kumba, A, 109. manganda', H IV, 28.

Manggoali, B, 29. manginta', F, 26. Mangkakalena, A, 47. mangore tanda tinaran, A, 110. mangrompe letokan, A, 113. Manurundilangi', zie A, blz. $432 \mathrm{v}$.

Mapaken, E Ib, 28.

ma'parekke para = demmeran para, H III, 205.

ma'pasilosongan, E Ib, 81. ma'polo lolo, B, 15. ma'punti disasa, C, 1. ma'rebongan didi, A, 113. ma'rio-rio, E Ia, 23. ma'muang, A, 106. marudinding, H IV, 92. masak, H I, 1. masakke, F, 86. masala, F, 131. masindung, H II, 39. mata bubun, C, 68 . mata buntunna, C, 89. ma'tallu rarai: drie soorten bloed bezigen.

Matari'allo, E III, 40. ma'tengko randuk, A, 118. mekaindo, G, 35. melzolo tau, A, 117.

membunga rangka, H III, 157. Mendurana, B, 14.

mengkailing tanduk, 1t1. het hoofd van "neen" schudden als waren het horens.

Mentang, F, 126.

moka $=$ nok $a, \mathrm{G}, 44$.

mokurungan, H IV, 93 en F, 72 . mosaung, F, 72.

nabarre-alloi, A, 116.

nakitta', F, 23.

nakulea'i, E Ia, 107. nakundala-dala, E IV, 24 en

H III, 260.

nalembangan, $\mathrm{H} \mathrm{I}, 79$.

nalindo-bulanni, A, 116. napariai, C, 45.

nopabanno kamumin, C, 56.

napabarinni, E Ia, 60.

Napo, E Ib, 35.

napokombutu' maringan, C, 8 .

napopa'indo' tama rebongan didi, $\mathrm{A}, 115$.

napotedong-tedong uma, A, 30 en

125.

narande tana kalua', C, 90. nascrande, nevenvorm van narande,

in Pangalase d.t. nasarandek,

C, 19.

nasurrun, H III, 145.

nedo'-nedo' $=n e^{\prime}$ do-ne'do =

tedo'-tedo', H III, 335.

nuang, E Ia, 206.

pa'barusan: scheiding in het

haar, vgl. bam' I (WB., 51b).

pakajun bimbang, C, 39.

Palesan, E III, 75 .

palo-palo, E Ia, 9.

Pande Paliuk, A, 70v.

Pande Patangnga', A, 70.

pandoko, A, 65.

Pangala, E III, 59.

pangarru', E Ia, 86.

pangi, E II, 7 .

pangkalo' puang, 1t1. greppel

door de goden gegraven.

pan $(t)$ oto, H IV, 16.

papa rara', A, 126.

pa'palumpun, C, 84 .

pa'paramikan = surasan tallang,

E II, 13.

Paparilangi': Dakbedekking van

het uitspansel, vgl, papa

(Wb., 439)v.

paria tannun, G, 57.

pasandak salu lako rampanan

kapa', A, 114.

passakke, F, 87.

passasaran tuju, H I, 36.

passulean alzo, C, 15.

Patalabintin, A, 16.

Patalabunga, A, 15.

Patodenmanik, B, 30 .

patola, E III, 7 .

pecompu, B, 8 .

peassa', E Ia, 138.

Pedamaran, zie op E Ib, 21.

pempaja alzo, H I, 3.

penaa, C, 34.

penomile, H III, 103.

pennommu', E III, 42.

penggirikan, H II, 10.

pepaju, E Ia, 109.

petaa, F, 35 . 
petuo, E Ia, 262.

pisik, H I, 76.

pisik-pisik = kaise'.

pising-pising $=$ pisik,

H III, 132 .

Pong Buatabang, z.o. het tweede woord.

Pong Mulatau, A, 80 .

Pongko, A, 100.

Pong Tulakpadang, A, 6 .

Pong Tulangdidi', H I, 12.

ponto Zola', E Ia, 66.

Pottokalembang, A, 29.

puang banga', E Ia, 26.

Puang Maro, A, 45.

Puang Matua, A, 9.

Puang Matua Dolo, C, 34 .

pu(j)o, H III, 107.

pussa, F, 46.

rampe matampu': de Westzijde, vgl. A, 84.

randuk pudukna mandoti, H III, 304.

Rangri: gebergte tussen de landschappen Buntao' en Rantebua. rara', H III, 368.

ra'tuk Zangi', E Ia, 113.

rau-rau, E Ia, 298.

raukan tedong, H III, 206.

rendenan tedong, B, 11 .

rombe ao', E Ia, 287.

roto, $\mathrm{F}, 107$.

roto api, E Ia, 84.

mumajuk, H II, 7.

mumasse, A, 102.

mumende-mende sarapang, A, 133.

ru'sen, E Ia, 18.

sa'dan, E Ia, 150.

Sa'dan: naam van de rivier die door Tana Toradja en Enrekang stroomt en in het Zuiden van

Pinrang in Straat Makassar uitmondt; en naam van het landschap, E III, 48.

sa'de banua, E IV, 15.

Sado'ko', E Ib, 41.

sakka' saenanna, C, 90.

salle manik, E Ia, 25.

salombe', E Ib, 24.

Salu, F, 89.

Salusule, E Ib, 32.

sambalin, E Ia, 16.

Sampurari, A, 122.

sangdundun pindan, A, 89.

sanggaria, E Ia, 9.

sangpemanakki, E Ib, 40.

sangsaroan, H III, 333.

sangserekan, A, 137. sarang-sarang, H IV, 77.

Sarira, E Ia, 315.

sarita, E Ib, 70 .

seko manik, E Ib, 70.

seleng, H III, 107.

sembangan ongan, 1tl. het kappen

van schaduwtakken, bij een

offerritueel.

sendana balo', A, 43.

sendana bonga, G, 21.

sendana lalong, A, 85.

sendana sugi', G, 21.

Sepang, E III, 31.

serre' datu: de heilige kat.

Sesean, A, 130.

siajoka, E III, 10.

sidulu: hetzelfde eet- of drinkgerei gebruiken met een ander.

Siguntu', E Ib, 62.

sikatadisi-disian = sitaradisi disian, H III, 267.

Sikuku', B, 13.

simbolong, E Ia, 43, vgl. C, 14.

Simbuang, E III, 73.

Sinadi, E Ib, 43.

Singki', E Ib, 58 .

sirenden, H II, 4.

sisulu': wederzijds afgrendelen, vg1. A, 69.

sitanduk, G, 11.

sitaradisi-disian = sikatadisidisian, H II, 54.

sitontongan allo, H III, 188.

sokko kalale', A, 128.

songi-songi, H I, 34 .

Sopai, E Ib, 38.

sulunan, H IV, 36.

sumanga', H III, 113.

sumarre-marre, H III, 133.

sumbang, H IV, 21.

sumomba, H I, 3 .

sumusunna, E Ia, 130.

sunga' = sumanga', C, 34 .

surasan tallang, E II, 13.

suru', E IV, 1.

Suso, F, 79 .

Tabang, E III, 65.

tadoran: bamboestaak waaraan

uiteengeplozen jonge bladeren

van de arenpalm worden ge-

hangen.

tai, 1t1. faeces, overdrachte-

lijk: nageslacht.

talza', A, 88.

tallang, E III, 1.

tallang bunu', E Ia, 197.

Tallu lembangna, C, 66. 
talZu Zolona, E IV, 10 en

H IV, 74 .

Tammuanbida', C, 35.

tana', C, 5 .

tana' bassi, A, 94.

tana' bulaan, A, 95.

tananan bua', H III, 206.

tandung tiulunna langi': het

rijstveld aan het boveneinde

van het uitspansel.

tang beluakan, H IV, 37.

tantanan pusuk, 1tl. het uiteenhalen van de jonge bladeren

van de arenpalm.

tasak, C, 23.

telang, E Ia, 262.

tengko tiranduk: de ploeg die in de grond gedreven wordt, zie A, 57.

Tete, E Ib, 25.

tetean tompo, A, 82 .

Te'tekan, F, 79 .

tian, E Ia, 88.

tiguririkna, 1t1. het omgeven zijn door.

$t i i=t u i$.

tiladung = tiladun, vgl. tikaladun: bedekt, beschut (Wb., $252 \mathrm{~b}$ ) .

tinggi, C, 22 .

to $(j)$ ang, H III, 75.

to burake, A, 27.

toding, H II, 41.

to indo', A, 25.

to kabarre-alloan, C, 33.

to kabarrean kulla' = to kabarrealloan, C, 35.

to kaiangan = to kajangan, $\mathrm{H} \mathrm{IV}$, 52.

To Kaubanan, C, 6.

to kebalibi', E Ib, 14 en $\mathrm{H} \mathrm{II}$, 30 .

to kengkok $=$ to keengkok, $\mathrm{E} \mathrm{Ib}$, 14.

tokonan tedong: het meten van de afstand van de punt van de lans tot het hart van de buffel.

to ma'duang salu, C, 37.

to ma'gandang, A, 28.

tombi to Luwu: e.s.v. weefsels

die op de dodenfeesten worden uitgehangen, zie ook bij E IV, 9.

to menampa, E Ib, 1.

tongka' dilizana, C, 19.

to palullungan, $\mathrm{G}, 2$.

to pantan tarunona, G, 58 .

to petoe tabang: degene die het

Dracaena-blad hanteert.

to ponto litakan, A, 87.

to sanda rangka'na, G, 58.

to Se'ke', to Sarongbontik, to

Sinadi, E Ib, 43.

to situang tanduk: zij die horens droegen, vgl. A, 129.

to tang dikandean essun, H II, 18.

to torro to Zino, C, 75.

to tumbang, E Ia, Inleiding.

tuda-tuda, F, 106.

tui (= tii) tasik, A, 58 .

tromampa-mampami rara', A, 132.

Tumba', A, 10.

tumbang, E Ia, Inleiding.

tumbu kumuku' = tumbo kumuku': geluk aanbrengend.

tumusan bubun, H IV, 116.

tutungan bia', 1tl. het ontsteken van de fakkel, in d.t. de aanduiding van een zoenoffer om heil en zegen te verwerven. ullembong = unnembong: goud wassen en zeven.

umpotendeng-tendengna, A, 124. unnembong sukaran aluk: het offerritueel zuiveren.

unnika' to matuanna: een offer aan zijn voorouders brengen bij hun graf.

unnorong kaso ditomben, B, 25. untarmui bugi, E Ia, 9. 


\section{AFKORTINGEN EN AANGEHAALDE GESCHRIFTEN}

d.t. = dichterlijke taai

Adriani, V.G. = N. Adriani, Verzamelde Geschriften, I-III (Haarlem, 1932).

Matthes, Boegin. Wb. = B.F. Matthes, Boegineesch-Hollandsch Woordenboek (Amsterdam, 1974).

The Chant = H. v.d. Veen, The Sa'dan Toradja Chant for the Deceased, in VKI, 49 (1966).

The Merok Feast $=$ H. v.d. Veen, The Merok Feast of the Sa'dan Toradja, in VK.I, 45 (1965).

Wb. $\quad=$ H. v.d. Veen, Tae'( Zuid-Toradjasch)-Nederlandssh Woordenboek (Den Haag, 1940).

Naar de overige geschriften wordt verwezen met de naam van de auteur en het jaar van publicatie:

N. Adriani en A.C. Kruyt, De Bare'e sprekende T'oradja's van MiddenCelebe's, II (Amsterdam, 1951).

E. Crystal, "Ritual of Renewal", in Orientations, 4/12 (Dec. 1973), $26-32$.

J. Kruyt, "Het maboea' en de tatouage in Seko (Midden-Celebes)", in $B K I, 76$ (1920), 235-257.

- - , "De boea' en eenige andere feesten der Toradja's van Rantepao en Ma'kale", in TBG, 60 (1921), 45-77.

A.A. v.d. Loosdrecht en N. Adriani, "Pano Boelaan", in Mededeelingen Nederl. Zendelinggenootschap, 58 (1914), 225-244.

E.A.J. Nobele, "Memorie van overgave betreffende de onderafdeling Ma'kale", in $T B G, 66(1926), 1-143$.

C.H.M. Nooy-Palm, "Introduction to the Sa'dan Toraja People and their Country", in Archipel, 10 (1975), 53-91.

H. v.d. Veen, Sa'dan Toradja'se Volksverhalen, in VBG, 65/2 (1924).

- _ - , "Ossoran tempon daomai langi"", in BKI, 132 (1976), 418-438; in de aantekeningen ook "Tekst A" genoemd.

ERRATA

Blz. 142, regel 38 penommu', 1ees: pennarmu'

" 213, " 1 BANGKULA, lees: BANGKULA' 